\title{
Development of a
}

\section{Context-Aware Smart}

Home Energy Manager (CASHEM)

Prepared for:

Emerging Technologies Program

Building Technologies Office

Office of Energy Efficiency and Renewable Energy

U.S. Department of Energy

\section{Prepared by:}

Pacific Northwest National Laboratory 


\title{
DISCLAIMER
}

This report was prepared as an account of work sponsored by an agency of the United States Government. Neither the United States Government nor any agency thereof, nor Battelle Memorial Institute, nor any of their employees, makes any warranty, express or implied, or assumes any legal liability or responsibility for the accuracy, completeness, or usefulness of any information, apparatus, product, or process disclosed, or represents that its use would not infringe privately owned rights. Reference herein to any specific commercial product, process, or service by trade name, trademark, manufacturer, or otherwise does not necessarily constitute or imply its endorsement, recommendation, or favoring by the United States Government or any agency thereof, or Battelle Memorial Institute. The views and opinions of authors expressed herein do not necessarily state or reflect those of the United States Government or any agency thereof.

\author{
PACIFIC NORTHWEST NATIONAL LABORATORY \\ operated by \\ BATTELLE \\ for the \\ UNITED STATES DEPARTMENT OF ENERGY \\ under Contract DE-AC05-76RL01830
}

Printed in the United States of America

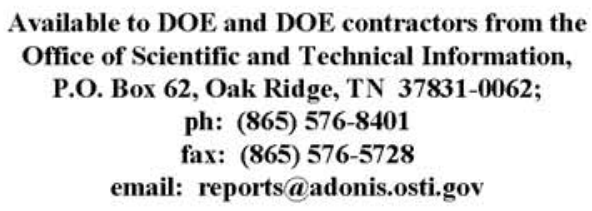

Available to the public from the National Technical Information Service 5301 Shawnee Rd., Alexandria, VA 22312 ph: (800) 553-NTIS (6847) email: orders $a$ ntis.gov $<$ http://www.ntis.gov/about/form.aspx > Online ordering: http://www.ntis.gov 


\title{
Development of a Context-Aware Smart Home Energy Manager (CASHEM)
}

\author{
V Srivastava \\ GB Parker \\ A Makhmalbaf
}

March 2013

Prepared for

Emerging Technologies Program

Building Technologies Office

Office of Energy Efficiency and Renewable Energy

U.S. Department of Energy

Prepared by

Pacific Northwest National Laboratory 



\section{Summary}

The research reported is part of a collaborative research project with Honeywell, International to bring novel home energy management concepts and technologies to reduce energy consumption, reduce peak electricity demand, integrate renewable energy and storage technology, and change homeowner behavior to manage and consume less energy. The objective of the collaborative research is to create a Context-Aware Smart Home Energy Manager (CASHEM) that dynamically schedules major home appliances according to conditions (appliance type, electric utility price) and homeowner convenience of service $(\mathrm{CoS})$ preferences (preferred time of use, average number of uses), monitors and analyzes energy consumption of appliances, recommends further energy saving actions, and engages/motivates the homeowner to adopt those recommendations.

The role of Pacific Northwest National Laboratory (PNNL) in this collaborative was to:

1. Identify and develop algorithms and to model the effects of various conditions in the house for the on-demand appliances, and recommend the best mode of operations for these appliances.

2. Evaluate the technologies and potential for on-site residential-scale energy generation and storage to integrate with demand and energy management strategies.

3. Identify algorithms to monitor the actual use of the on-demand appliances, and recommend better modes of operations via a user interface that accounts for user preferences with the potential to reduce demand and energy consumption.

4. Provide technical assistance as requested by Honeywell in the design of their experiment, monitor the execution of the demonstration and review the results of the pilot study being undertaken by Honeywell.

The role of Honeywell in this project, under a separate contract with the U.S. Department of Energy (DOE) is to conduct a pilot of a CASHEM at up to 10 houses in two cities in the United States. These houses will be provisioned with home energy managers, one or more grid-connected and necessary controls and sensors for optimal energy conservation. These pilots will run for 4 months during which time the home energy manager will provide energy management and demand response services (where available). The data will be captured, analyzed and reported in a separate report to the DOE. 



\section{Acronyms and Abbreviations}

$\begin{array}{ll}\text { AC } & \text { alternating current } \\ \text { CASHEM } & \text { Context Aware Smart Home Energy Manager } \\ \text { CHP } & \text { combined heat and power } \\ \text { CoS } & \text { convenience of service } \\ \text { DC } & \text { direct current } \\ \text { DOE } & \text { U.S. Department of Energy } \\ \text { DR } & \text { demand response } \\ \text { EIA } & \text { Energy Information Administration } \\ \text { ELCAP } & \text { End-Use Load and Consumer Assessment Program } \\ \text { EMC } & \text { energy management controller } \\ \text { EPA } & \text { Environmental Protection Agency } \\ \text { FFT } & \text { fast Fourier transform } \\ \text { FSEC } & \text { Florida Solar Energy Center } \\ \text { HEM } & \text { home energy management } \\ \text { HERS } & \text { Home Energy Rating System } \\ \text { HVAC } & \text { heating, ventilating, and air conditioning } \\ \text { LCD } & \text { liquid crystal display } \\ \text { NAHB } & \text { National Association of Homebuilders } \\ \text { NEAT } & \text { National Energy Audit Tool } \\ \text { NILM } & \text { Non-intrusive load monitoring } \\ \text { NREL } & \text { National Renewable Energy Laboratory } \\ \text { PC } & \text { personal computer } \\ \text { PIER } & \text { California Public Interest Energy Research } \\ \text { PMP } & \text { project management plan } \\ \text { PV } & \text { thotovoltaic } \\ \text { SQ } & \text { uninterruptible power supply } \\ \text { TCA } & \\ \text { UPS } & \end{array}$





\section{Contents}

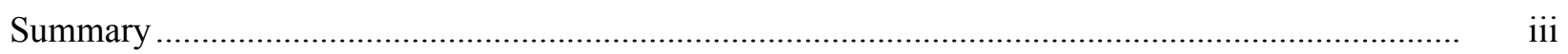

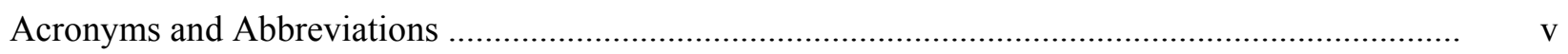

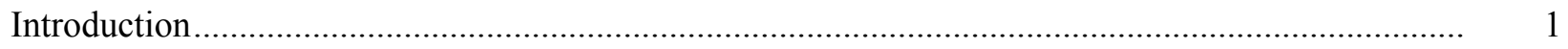

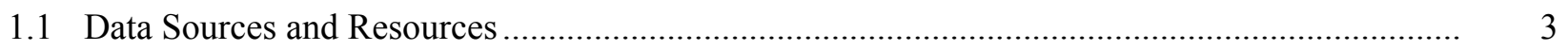

1.2 Define Scope of On-Demand Home Appliances ................................................................ 5

1.2.1 Smart Appliances Commercially Available in the Short Term ...................................... 5

1.2.2 Appliances with Maximum Potential for HEM Integration .......................................... 10

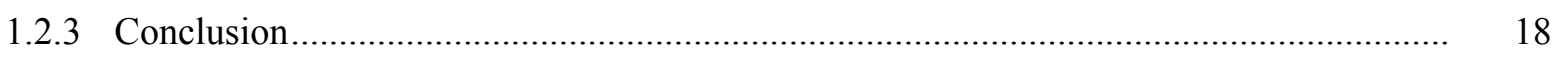

1.3 Onsite Electricity, Heat Generators and Storage for Residential Applications ......................... 19

1.3.1 Characterization of Energy Use and Load in a Home ................................................... 19

1.3.2 Residential On-Site Generation Technologies ........................................................... 20

1.3.3 Cost Analysis for On-Site Generation in Single-Family Residences ............................. 24

1.3.4 Integration of On-Site Generation Technologies and Home Energy Management.......... 24

1.3.5 State and Federal Incentives for Residential On-Site Generation Technologies.............. $\quad 26$

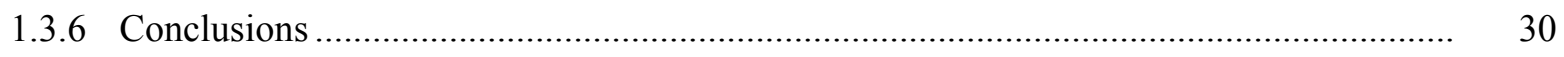

1.4 Define Residential Building Demographics and Characterize Homes and Appliance Use......... 32

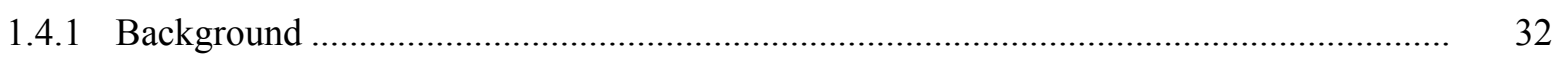

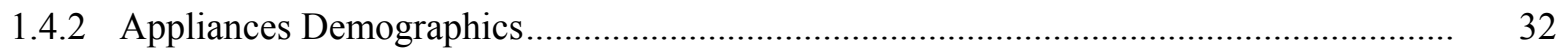

1.4.3 Compare/Contrast with CASHEM Demographics ........................................................ 35

1.4.4 Characterize the Market for the Down-Selected Appliance ............................................ 36

1.4.5 Characterize the Market for the Down-Selected Generation Device .............................. 41

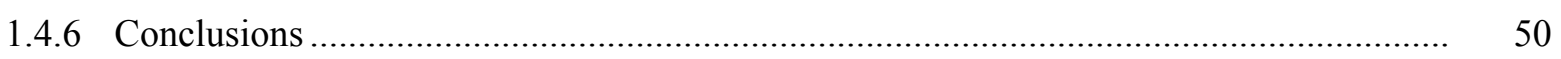

1.5 Data Analysis to Determine User Preference and Type Characteristic .................................. 50

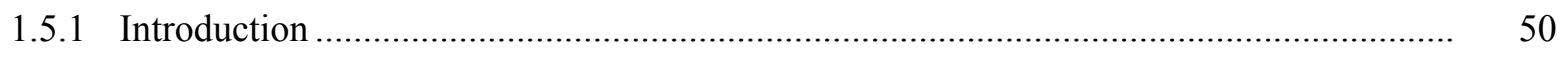

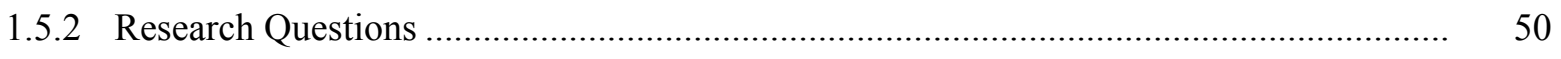

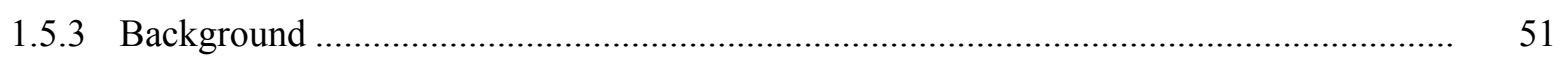

1.5.4 User Type Characterization ..................................................................................... 54

1.5.5 Frequency of Use of Appliances Based on Number of Occupants ................................. 57

1.5.6 Energy Use Profiles............................................................................................... 57

1.5.7 Average Energy Use Profile and Schedules Based on EnergyPlus and ELCAP ............. 65

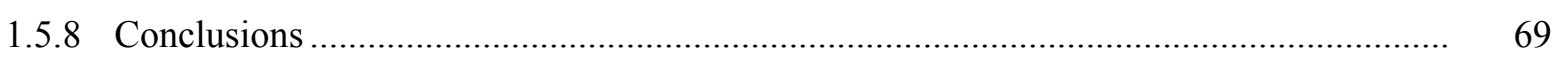

1.6 A Review of Algorithms to Infer Occupant Preferences ...................................................... 71

1.6.1 Algorithms to Infer Periods of Occupancy ................................................................... 71

1.6.2 Algorithms to Infer Electrical Energy Usage Patterns and Occupant Preferences........... 72

1.6.3 Proposed Path for Algorithm Development ................................................................ 76

1.6.4 Define Potential Usage Recommendations for Occupant Feedback .............................. 79 
1.6.5 Proposed CASHEM User Recommendation Framework

1.7 References.

Appendix A - Appliance Load Shapes in a 24-Hour Period Generated Using Appliance Models Contained in GridLAB-D Simulation Software

Appendix B - Market Size Estimation for Replacement Appliances Based on Age.....

B. 1 


\section{Figures}

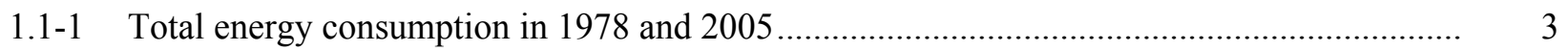

1.1-2 The percentage of total homes in the US using electricity for different end uses.................. 5

1.2-1 Multi-state load model of a dishwasher developed in GridLAB-D ...................................... 13

1.2-2 Replacement trend of appliances based on year of construction of homes............................ 15

1.2-3 Estimate of number of appliances with replacement potential ........................................... 16

1.2-4 Minimum and maximum appliance demand shift possible................................................ 17

1.3-4 Average home energy expenditures for selected states, 2009....................................... 26

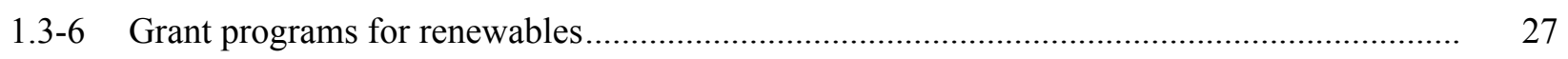

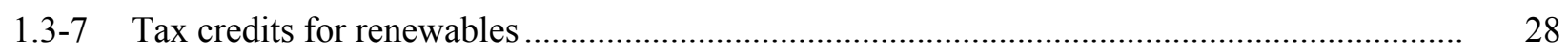

1.3-8 Rebate programs for renewables in different states ........................................................ 28

1.3-9 Sales tax incentives for renewables in different states................................................... 29

1.3-10 Direct cash incentives available for solar projects ......................................................... 30

1.4-1 Total number of appliances that are ready for replacement in addition to estimate of annual new units installed ................................................................................................ 32

1.4-2 Change in total number of appliances in the U.S. based on year of construction of homes .... 33

1.4-3 Change in total number of appliances based on household income...................................... 34

1.4-4 Trend in total number of appliances based on the U.S. census regions ................................ 34

1.4-5 Trend in total number of appliances based on climate region ............................................ 35

1.4-6 Distribution of housing units in different census regions ............................................... 36

1.4-7 Distribution of housing units in different climate regions ................................................. 36

1.4-8 Distribution of units that have replacement potential in each decade.................................. 37

1.4-9 Distribution of units that have replacement potential in different census regions in the U.S.. 38

1.4-10 IECC simplified map of climate regions in the United States ............................................ 39

1.4-11 Distribution of units that have replacement potential in different climate regions in the U.S

1.4-12 Distribution of units that have replacement potential based on household income ................ 40

1.4-13 Income level in different census regions......................................................................... 41

1.4-14 EPA tracked sites with community wind energy generation potential ................................. 43

1.4-15 EPA tracked sites in Minnesota with community wind energy generation potential ............. 44

1.4-16 EPA tracked sites with PV policy driven and/or utility scale PV solar energy generation potential

1.4-17 Solar energy payback calculator for 2012-2013 for Minneapolis, MN ............................... 46

1.4-18 EPA tracked sites with biopower facility siting potential .................................................. 47

1.4-19 EPA tracked sites with biorefinery facility siting potential ............................................. 47

1.4-20 EPA tracked sites in Minnesota with Biorefinery facility siting potential............................ 48

1.4-21 EPA tracked sites in Minnesota with Biopower facility siting potential .............................. 48

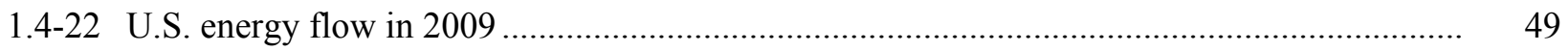




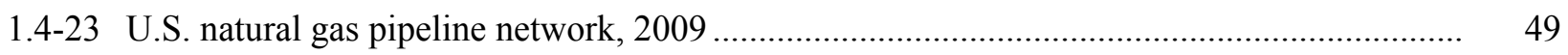

1.5-1 Average savings resulted from historical feedback programs .......................................... 53

1.5-2 Model of players in energy consumption based on Aune (1998) found in Naesje et al. (2005)

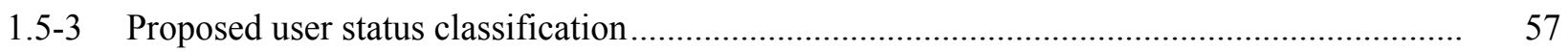

1.5-4 Number of electric stoves based on number of household members ................................... 58

1.5-5 Frequency of cooking based on number of household members .......................................... 58

1.5-6 Number of homes that do use or not use a dishwasher based on number of household

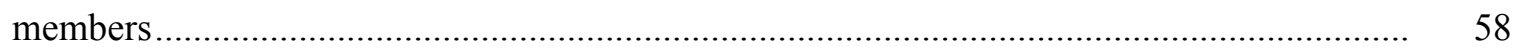

1.5-7 Frequency of use of dishwasher based on number of household members .......................... 59

1.5-8 Number of clothes washers used based on number of household members .......................... 59

1.5-9 Frequency of use of clothes washer based on number of household members...................... 59

1.5-10 Number of electric clothes dryers used at home based on number of household members.... $\quad 60$

1.5-11 Frequency of use of clothes dryer based on number of household members ....................... 60

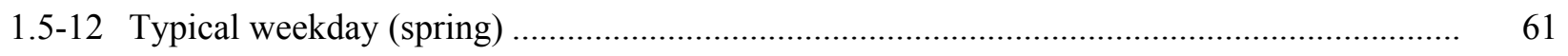

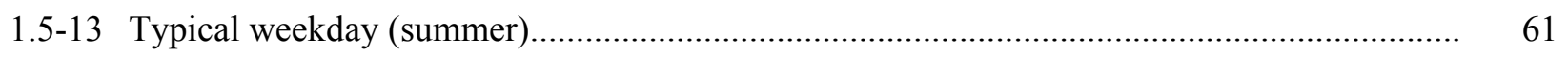

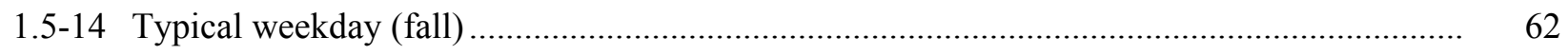

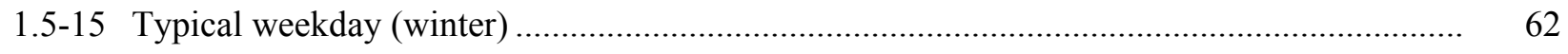

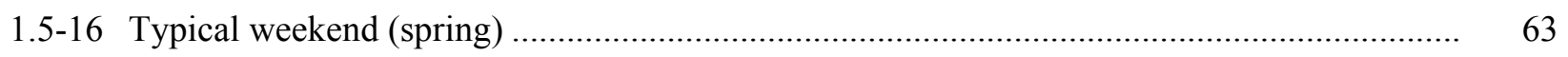

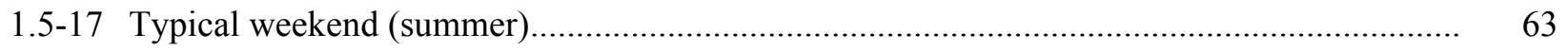

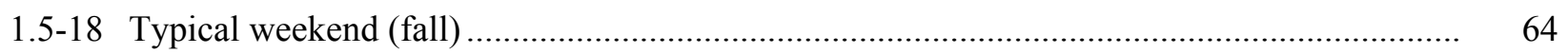

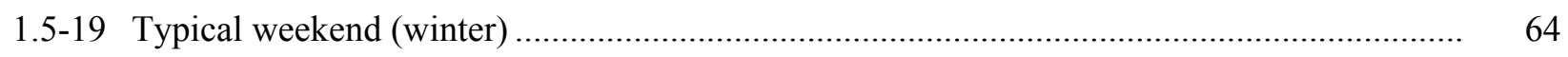

1.5-20 Clothes dryer schedule modeled in EnergyPlus................................................................. 66

1.5-21 Clothes dryer load profile from ELCAP data .................................................................... 66

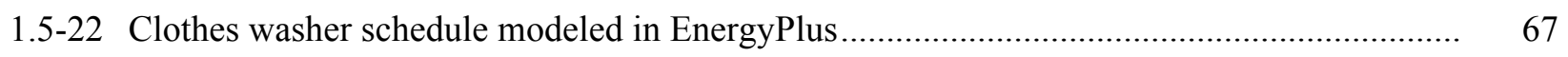

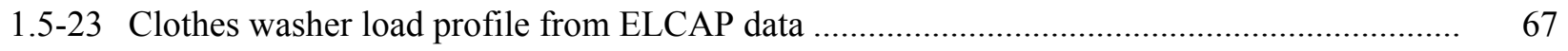

1.5-24 Dishwasher schedule modeled in EnergyPlus .................................................................... 68

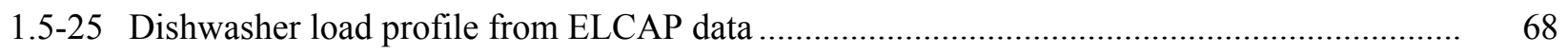

1.5-26 The process of deriving and generating recommendations using user characterization and

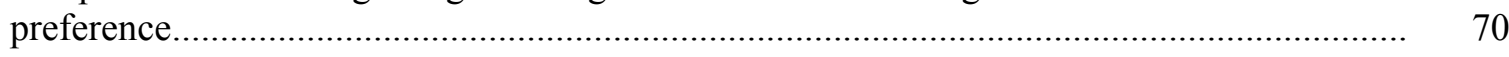

1.6-7 Dishwasher model from GridLAB-D ......................................................................... 78

1.6-8 A flowchart for a proposed recommendation framework for CASHEM ............................. 83 


\section{Tables}

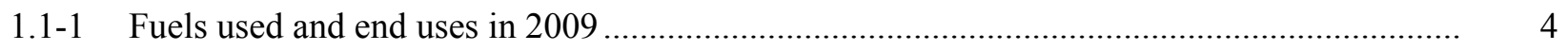

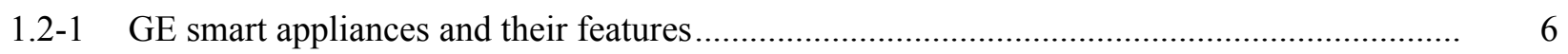

1.2-2 GE smart appliances with the ability to communicate through Nucleus with Brillion ${ }^{\mathrm{TM}}$

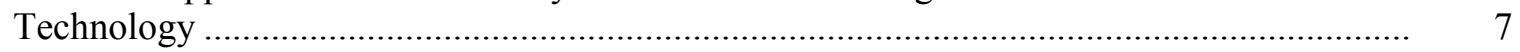

1.2-3 Key features of Miele Appliances relevant to CASHEM .................................................... 8

1.2-4 Key features of LG appliances relevant to CASHEM ..................................................... 9

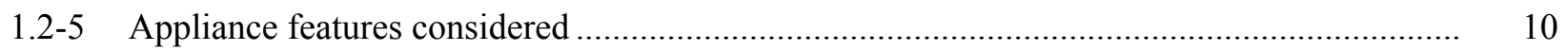

1.2-6 An example of utility companies with community scale HEM programs .............................. 12

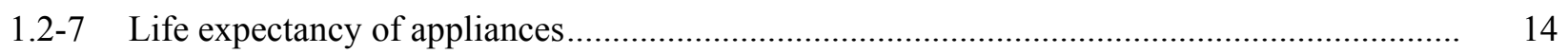

1.2-8 Estimate of market size of appliances and pool pumps ................................................... 15

1.2-9 Estimate of demand shift potential by smart appliances in one operation cycle..................... 16

1.2-10 Rank order of appliances based on maximum potential for HEM integration....................... 18

1.3-1 Estimation of cost for installing and operating residential on-site generation systems .......... 25

1.3-2 Estimated cost for hybrid on-site generation systems....................................................... 26

1.3-3 Summary of on-site generation incentives available in Minnesota ..................................... 29

1.3-4 Ranking of on-site generation technologies based on the $\$ / \mathrm{kW}$ and attributes documented

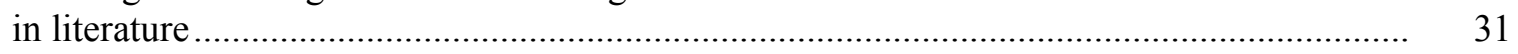

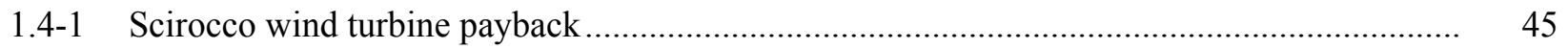

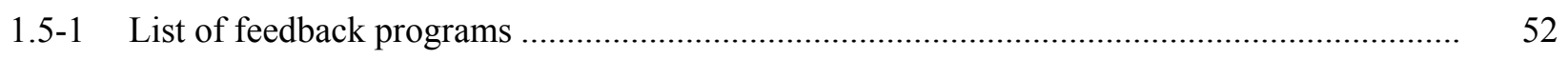

1.5-2 Description of the homes participating in the FSEC metering study ................................... 60

1.6-1 ZIP models are two state models, energized and de-energized ........................................... 77

1.6-2 Example of recommendation for dishwasher for two different user types .......................... 84 



\section{Introduction}

The work documented in this report supports the development of a context-aware smart home energy manager (CASHEM) in a collaborative research project with Honeywell. The overall objective of the CASHEM project is to create a system that dynamically schedules major home appliance use according to conditions and homeowner convenience of service $(\mathrm{CoS})$ preferences, monitors and analyzes energy consumption, recommends further energy saving actions, and engages/motivates the homeowner to adopt those recommendations. By automating energy saving actions in combination with adaptive techniques while focusing on highly energy consuming appliances such as space conditioning, water heaters, and pool pumps, savings between 16 and $20 \%$ of energy consumed could be achieved based on the homeowner and 'comfort/convenience' tolerance level.

A home energy management (HEM) approach using CASHEM addresses the problem of heterogeneity by adapting its recommendations to homeowners' expressed preferences for CoS, gathered at system configuration time. Also, the system monitors energy use behaviors under different activity or occupancy conditions and suggests adjustments to appliance use. The CASHEM monitors inputs from multiple sources to create a hypothesis of the current state and to build patterns of energy use in the home over time. These patterns enable the determination of homeowner $\mathrm{CoS}$ preferences and the generation of recommendations. The monitored inputs include occupancy sensors, indications from the security system, positions of light switches, hot water consumption, and appliance activity (e.g., the operation of the dishwasher) as well as time of day. The CASHEM can then adjust the time of operation for these appliances to be recommended to the user to match the actual schedule followed by the user, rather than a pre-programmed schedule that ignores user preference. The value of the CASHEM is expected to increase as more context information becomes available, as the system learns more about occupant behavior, and as more CASHEM-connected appliances are installed.

This project investigated the contexts that affect operation of home appliances to configure a context driven appliance $\mathrm{CoS}$ model that correlates the different conditions to the energy consumption, and dynamically schedules the appliances under the stated conditions. The type and amount of CoS deviation was assumed to vary across homeowners. The challenge for the project was to reduce energy consumption while minimizing inconvenience and keeping the user satisfied.

This project included the analysis of home energy consumption and occupancy characteristics data from publically available databases to recommend better modes of operation for on-demand home appliances and also included the definition of novel algorithms in parallel with Honeywell's CASHEM algorithm development to provide the U.S. Department of Energy (DOE) with a broader technology base of automated context-awareness determination. A business case for CASHEM was also developed.

The first deliverable for the project was a Project Management Plan (PMP) that was shared with DOE and Honeywell The PMP was revised based on DOE and Honeywell comments and finalized.. There were initially seven tasks in the PMP and as the project progressed, it was agreed to combine Task 1.1 and Task 1.5 into a single deliverable (an Excel database).

The following tasks were completed by Pacific Northwest National Laboratory (PNNL) and are described in detail in this report. As they were completed, they were shared with Honeywell for review and comment. Honeywell comments were incorporated and the final task was delivered to Honeywell, as a letter report. 
1. Task 1.1 Data Source and Resources: Residential-based data sources and resources most relevant to the development of CASHEM were identified and a spreadsheet containing collected data was compiled and provided to Honeywell This data set also included data developed for Task 1.5 in the PMP which was a selection of sets of overlapping and non-overlapping (demographic basis) data to be used in Honeywell's CASHEM algorithm development. The most useful and relevant public data were found in data bases from the Florida Solar Energy Center (FSEC) and the DOE Residential Energy Consumption Survey (RECS) data.

2. Task 1.2 Define Scope of On-Demand Home Appliances: On-demand (grid-enabled) home appliances were evaluated, including those that are currently commercially available and those that are expected to be available in the longer term. In this examination, it was found that integrating residential electric water heaters with home energy managers provided the maximum benefit in reducing electric demand and potentially reducing the consumer electrical bill.

3. Task 1.3 On-Site Electricity Heat Generators and Storage for Residential Applications: An investigation was performed for on-site electricity and heat generators and storage. It was concluded that given their capability to be readily dispatched and low capital cost, internal combustion engines were the most suitable for integration with a CASHEM system. The use of water heaters as storage devices was found to further increase the benefits provided by these systems.

4. Task 1.4 Define Residential Building Demographics and Characterize Homes, and Appliance Use: This task focused on defining residential building demographics using publically-available data sources to compare/contrast with demographics selected for the CASHEM pilot demonstration. At the time this task was initiated, the CASHEM pilot demonstration was selected to be five homes in the greater Minneapolis metropolitan area and thus the characteristics and demographics of the pilot project were shared with PNNL. A second focus was on characterizing appliances on the basis of their replacement potential which is an indicator of how quickly penetration of grid-connected appliances could be expected to take place. As an example of the findings, most clothes washers with replacement potential are located in homes constructed 1970 to 1979 and most refrigerators and clothes dryers are in homes constructed between 1980 to 1989. These ages are of the homes and not of the appliances in the homes that may have been installed or replaced after the home was built.

5. Task 1.5 Data Analysis to Determine User Preference and Type Characteristic: The focus of this task was to find parameters that can be used to derive the most effective recommendations to be generated by a CASHEM device. A literature review was performed to find factors affecting energy consumption of single-family detached residential buildings. It was found that user's attitude towards energy consumption and factors such as income and household size have direct influence on how much energy is consumed. Existing research showed that 'social insights' are parameters that play a key role in derivation of influential and effective recommendations to reduce energy consumption through real-time feedback programs.

6. Task 1.6 A Review of Algorithms to Infer Occupant Preferences: In this section, a literature review of algorithms was undertaken to uncover algorithms that have been used to infer periods of occupancy, electrical energy usage patterns and occupant preferences, and to define potential usage recommendations for occupant feedback. Several algorithms were identified. From a review of the algorithms, it was observed that algorithms that model the voltage response of a device as a collection of constant impedance, constant current, and constant power elements, and using this model for matching signatures in measured electric use, would be an accurate representation for inferring periods of occupancy and electrical energy use and thus applicable for use in a CASHEM device. 


\subsection{Data Sources and Resources}

Data were gathered from the Residential Energy Consumption Survey (RECS) ${ }^{1}$ administered by the U.S. Department of Energy DOE Energy Information Administration (EIA) and summarized in an Excel file for Honeywell to archive for future use. The survey data included in the file is from 2009, but the total and average consumption data are from 2005. The EIA, on their website, states that "RECS consumption and expenditures data for 2009 are currently being collected and processed" and they have anticipated the first release of these data in early 2012, but was not yet available at the time the data were compiled. ${ }^{1}$ The 2009 data were collected from 12,083 households selected randomly (using a complex multistage, areaprobability sample design). This sample represents 113.6 million U.S. households; the U.S. Census Bureau's statistical estimate for all occupied housing units in 2009 derived from their American Community Survey. The EIA estimates energy consumption and end uses $^{2}$ in the U.S. by collecting energy characteristics on the housing unit, usage patterns, and household demographics. Energy costs and usage for heating, cooling, appliances and other end uses are then estimated using data from energy suppliers to these homes.

The data selected from RECS in the Excel spreadsheet file included demographics as well as the number of appliances, televisions, computers, space heating, air conditioning, and water heating for different housing unit types in the U.S. for year 2009. According to the EIA, the number of U.S. households has grown by 34.5 million from 1978 to 2009. Also, improved living standards have resulted in more households purchasing major appliances. The Pie Chart in Figure 1.1-1 shows how energy consumption (including all fuels) for appliances and electronics has increased from 17\% in 1978 to $31 \%$ in 2005 .
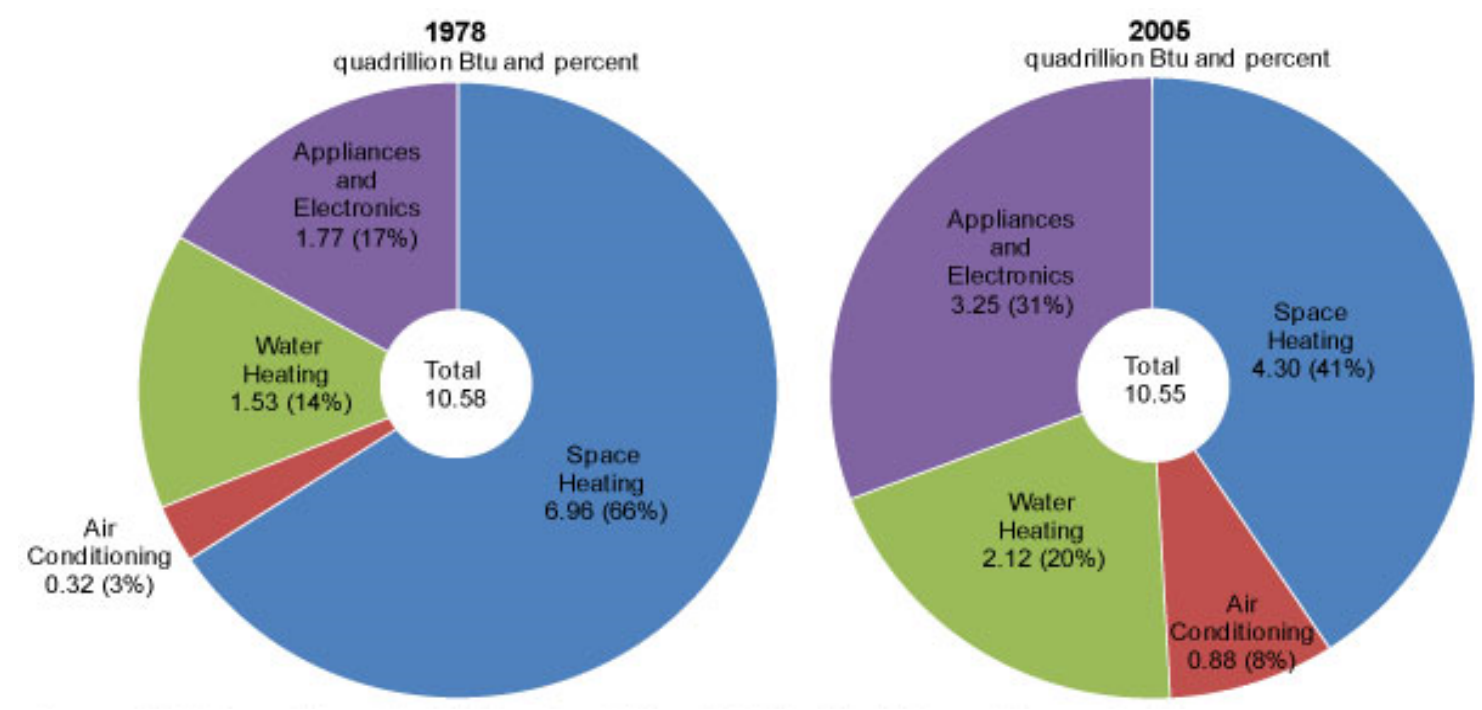

Figure 1.1-1. Total energy consumption in 1978 and 2005 (includes all fuels). Source: http://www.eia.gov/consumption/residential/reports/electronics.cfm

\footnotetext{
${ }^{1}$ Reference: http://www.eia.gov/consumption/residential/ RECS is a national sample survey that includes energyrelated data for different housing type units. The 2012 RECS data were released on June 6, 2012.

${ }^{2}$ End Use: A function for which fuels (energy sources) are used in the household. In RECS, there are five major energy end-use categories that were estimated: space heating, air-conditioning, water heating, refrigerators, and appliances. The amount of energy used for these end uses is estimated by means of a nonlinear regression technique, rather than by data that are actually measured.
} 
Table 1.1-1 shows different types of fuels and the number of housing units that used one or more types of of these fuels in 2009. All 113.6 million homes in the U.S. in 2009 used electricity (not exclusively) while 69.4 million homes (61\%) used Natural Gas in addition to electricity, about $43 \%$ were supplied by propane (not exclusively), and less than $11 \%$ had consumed other types of fuels. The number of housing units that consume electricity in different end uses, e.g., space heating, air-conditioning, water heating, and cooking is tabulated in the bottom of Table 1.1-1. This data is also presented graphically in Figure 1.1-2 showing that $51 \%$ of total homes in the U.S. use electricity for space heating $(34 \%$ is for main space heating and $24 \%$ secondary), $83 \%$ for air conditioning, $41 \%$ for water heating, $63 \%$ for cooking and finally all of them use it for other end uses such as refrigeration, lighting, electronics, etc. The number of detached single-family housing units show almost the same trend for electricity usage of different end uses: $49 \%$ use it for space heating (28\% main and $27 \%$ secondary), $85 \%$ for air conditioning, 38\% for water heating, $64 \%$ for cooking and finally all of them use electricity for other end uses, e.g., a refrigerator, washer, dryer, and other electrical plug loads.

Table 1.1-1. Fuels used and end uses in 2009.

Source: http://www.eia.gov/consumption/residential/data/2009/

\begin{tabular}{|c|c|c|c|c|c|c|}
\hline & \multicolumn{6}{|c|}{ Housing Unit Type (millions) } \\
\hline & \multirow[b]{2}{*}{$\begin{array}{c}\text { Total } \\
\text { Homes }\end{array}$} & \multicolumn{2}{|c|}{ Single-Family Units } & \multicolumn{2}{|c|}{ Apartments } & \multirow[b]{2}{*}{$\begin{array}{c}\text { Manufactured } \\
\text { Homes }\end{array}$} \\
\hline & & Detached & Attached & $\begin{array}{l}2 \text { to } 4 \\
\text { Units }\end{array}$ & $\begin{array}{c}5 \text { or } \\
\text { More Units } \\
\end{array}$ & \\
\hline & 113.6 & 71.8 & 6.7 & 9.0 & 19.1 & 6.9 \\
\hline \multicolumn{7}{|c|}{ Fuels Used for Any Use } \\
\hline Electricity & 113.6 & 71.8 & 6.7 & 9.0 & 19.1 & 6.9 \\
\hline Natural Gas. & 69.4 & 45.7 & 4.7 & 6.1 & 11.0 & 1.8 \\
\hline Propane/LPG ${ }^{(a)}$ & 48.9 & 39.6 & 2.4 & 1.7 & 2.0 & 3.2 \\
\hline Wood & 13.1 & 11.4 & 0.3 & 0.2 & 0.5 & 0.7 \\
\hline Fuel Oil & 7.6 & 5.1 & 0.4 & 0.7 & 1.3 & 0.1 \\
\hline Kerosene & 1.7 & 1.1 & $\mathrm{Q}^{(\mathrm{b})}$ & Q & Q & 0.5 \\
\hline Solar & 1.2 & 1.1 & Q & Q & Q & Q \\
\hline \multicolumn{7}{|c|}{ Electricity Consumed by Each End Use (more than one may apply) } \\
\hline Space Heating & 58.0 & 35.2 & 3.3 & 4.3 & 10.1 & 5.0 \\
\hline Main......... & 38.2 & 20.0 & 2.1 & 3.3 & 8.9 & 3.9 \\
\hline Secondary & 26.8 & 19.7 & 1.7 & 1.7 & 2.1 & 1.8 \\
\hline Air Conditioning & 94.0 & 61.1 & 5.6 & 6.3 & 15.2 & 5.8 \\
\hline Water Heating & 47.1 & 27.5 & 2.3 & 3.3 & 8.7 & 5.2 \\
\hline Cooking & 71.2 & 46.0 & 4.0 & 4.8 & 12.3 & 4.1 \\
\hline Other & 113.6 & 71.8 & 6.7 & 9.0 & 19.1 & 6.9 \\
\hline \multicolumn{7}{|c|}{$\begin{array}{l}\text { (a) LPG = liquefied petroleum gas } \\
\text { (b) EIA withheld data either because the Relative Standard Error (RSE) was greater than } 50 \text { percent or fewer than } 10 \\
\text { households were sampled. }\end{array}$} \\
\hline
\end{tabular}




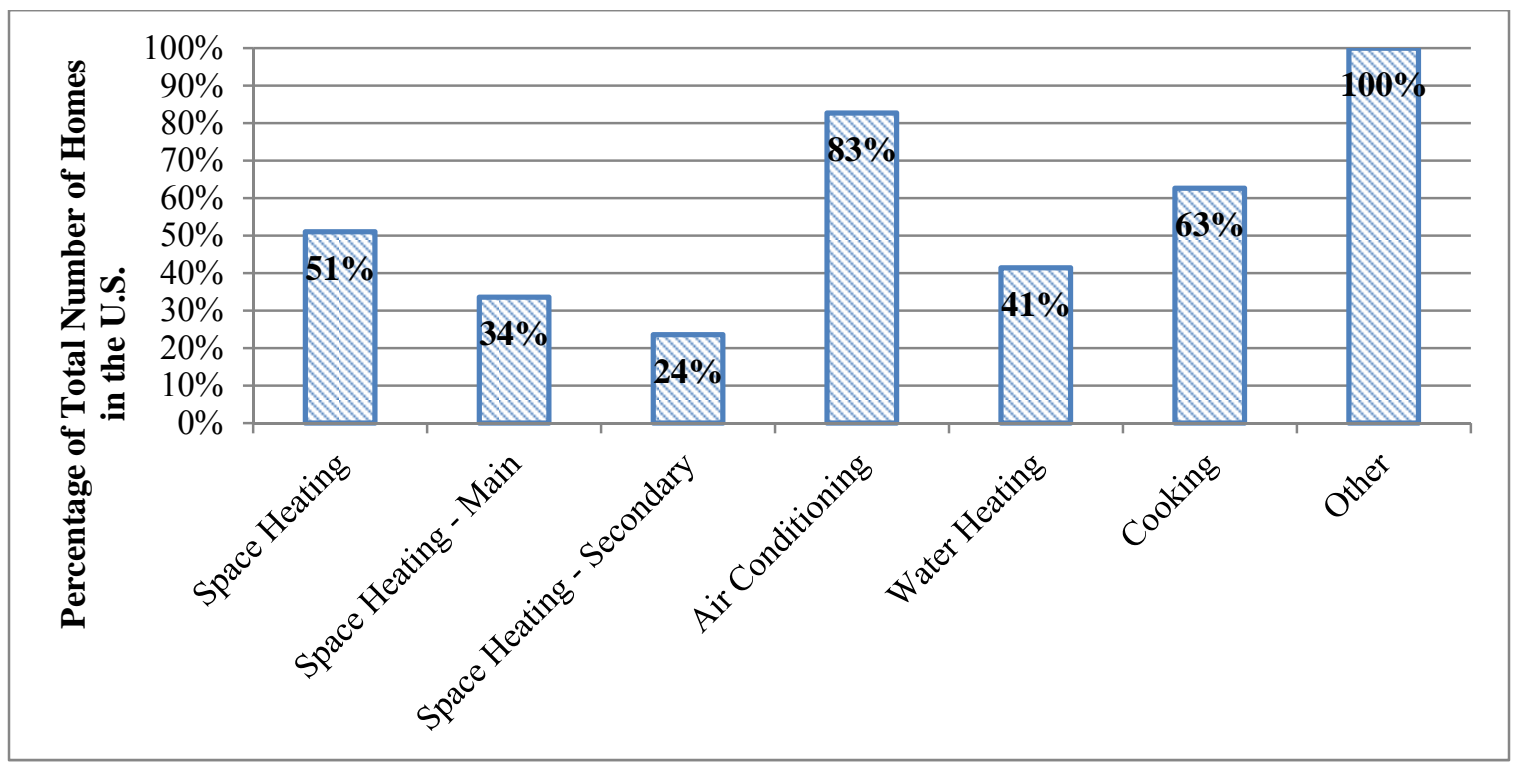

Figure 1.1-2. The percentage of total homes in the US using electricity for different end uses (these are only number of homes and not their energy consumption).

\subsection{Define Scope of On-Demand Home Appliances}

On-demand (grid-enabled) home appliances including those that are currently commercially available and those that are expected to be available in the short term(next 1-2 years) were evaluated in this section.

\subsubsection{Smart Appliances Commercially Available in the Short Term}

In this section, a number of demand response (DR) enabled home appliances that will be commercially available in the short term are identified. These appliances may also be referred to as smart appliances which are considered those with the capacity to directly respond to electric utility price signals as well as signals and commands supplied to them by an advanced HEM system. Cost savings for a consumer using such smart appliances can only be realized if the utility rate structure has time of use or other form of peak pricing tariff. Home appliances considered include clothes washers, clothes dryers, range / ovens, primary refrigerators, secondary refrigerators, dishwashers, televisions, computers, electronics equipment, water heaters, and pool pumps. Traditional heating, ventilation and airconditioning units are outside the scope of this task.

Based on literature and manufacturer's information available, we found that refrigerators, clothes washers, clothes dryers, dishwashers, ranges, and water heaters are the most common appliances considered by different manufacturers to utilize two-way communications to interact with the power grid, as well as HEM systems. GE Appliances, LG Electronics, Miele, Samsung Electronics, Bosch, Electrolux, Whirlpool and Indesit are the key industry players in this domain, as identified in a research report by Pike Research (Walton \& Gohn, 2010). Pike Research also estimates that North America will account for $43 \%$ of smart appliance world market by 2019 (Walton \& Gohn, 2010).

The following three sections document key features in smart appliances from GE, Miele, and LG. These are manufacturers that have released more data about their products. According to the report by 
Pike Research, other manufacturers such as Bosch, Electrolux, Whirlpool and Indesit are also working on supplying smart appliances. However, no publically-available data about specifications of their smart appliances was found at the time of writing this report.

\subsubsection{GE Appliances}

Table 1.2-1 contains a list of GE smart appliances and a summary of their features that was collected as part of this literature review (GE, 2012). All cost saving features embedded in these appliances can only be realized if there is a rate structure in place that has a demand or critical peak price charge. GE smart (i.e., Brillion ${ }^{\mathrm{TM}}$-enabled) appliances work with a GE-developed Nucleus energy manager to adjust their operation. Brillion is GE's HEM technology. It deploys GE's Nucleus to enable cooperative communication between appliances and the grid. The Nucleus can communicate with smart meters and smart appliances to collect and provide near real-time information about home energy use. The Nucleus energy manager is supported with a software program that can be installed on a personal computer and uses wireless technology to gather estimated energy usage data from smart meters installed and appliances enabled (GE, 2012). This information can then be displayed on a computer or smart phone. This display includes current energy usage, current electricity rate, history of electricity usage, and thermostat settings (from a GE thermostat).

Table 1.2-1. GE smart appliances and their features (GE, 2012).

\begin{tabular}{|c|c|c|c|}
\hline Appliances & $\begin{array}{c}\text { Demand Response } \\
\text { Characteristics }\end{array}$ & $\begin{array}{c}\text { Energy Saving Operational } \\
\text { Characteristics }\end{array}$ & $\begin{array}{l}\text { Consumer Energy } \\
\text { Control Characteristics }\end{array}$ \\
\hline Refrigerator & $\begin{array}{l}\text { Defrosting cycles } \\
\text { are automatically } \\
\text { delayed until low- } \\
\text { cost times of day. }\end{array}$ & $\begin{array}{l}\text { Quick Chill and Quick Defrost } \\
\text { features are disabled during high- } \\
\text { cost hours until that period is } \\
\text { over. }\end{array}$ & $\begin{array}{l}\text { Energy saving settings occur } \\
\text { automatically, but consumer can } \\
\text { easily override them with the } \\
\text { press of a button if Quick Chill } \\
\text { or Quick Defrost features are } \\
\text { needed. }\end{array}$ \\
\hline Clothes washer & $\begin{array}{l}\text { Automatically delay } \\
\text { start until energy } \\
\text { rates go down. }\end{array}$ & $\begin{array}{l}\text { During high-cost periods, the } \\
\text { washer automatically defaults to } \\
\text { the Low Energy wash cycle. }\end{array}$ & \multirow[t]{2}{*}{$\begin{array}{l}\text { Energy saving settings occur } \\
\text { automatically, but consumer can } \\
\text { easily override them with the } \\
\text { press of a button. }\end{array}$} \\
\hline Clothes dryer & $\begin{array}{l}\text { Automatically delay } \\
\text { start until energy } \\
\text { rates go down. }\end{array}$ & $\begin{array}{l}\text { Select Low Energy setting during } \\
\text { peak use hours. }\end{array}$ & \\
\hline Dishwasher & $\begin{array}{l}\text { Delay Start Cycle } \\
\text { (to run during low- } \\
\text { cost hours). }\end{array}$ & $\begin{array}{l}\text { Automatically sets to air-dry } \\
\text { during high-cost hours }\end{array}$ & $\begin{array}{l}\text { Energy saving settings occur } \\
\text { automatically, but consumer can } \\
\text { easily override them with the } \\
\text { press of a button. }\end{array}$ \\
\hline Range & $\begin{array}{l}\text { Self-clean feature is } \\
\text { disabled during } \\
\text { high-cost times. }\end{array}$ & $\begin{array}{l}\text { Cooktop surface automatically } \\
\text { reduces power use by } 20 \% \text { during } \\
\text { high-cost hours. } \\
\text { Automatically defaults to the } \\
\text { smaller, less energy-consuming } \\
\text { upper oven during peak use times. }\end{array}$ & $\begin{array}{l}\text { Energy saving settings happen } \\
\text { automatically, but consumer can } \\
\text { bypass the power-saver settings } \\
\text { to use both ovens. }\end{array}$ \\
\hline
\end{tabular}


Table 1.2-1. (contd)

\begin{tabular}{|c|c|c|c|}
\hline Appliances & $\begin{array}{l}\text { Demand Response } \\
\text { Characteristics }\end{array}$ & $\begin{array}{c}\text { Energy Saving Operational } \\
\text { Characteristics }\end{array}$ & $\begin{array}{c}\text { Consumer Energy } \\
\text { Control Characteristics }\end{array}$ \\
\hline $\begin{array}{l}\text { Microwave } \\
\text { Oven }\end{array}$ & $\begin{array}{l}\text { Low fan setting is } \\
\text { automatic default } \\
\text { during high cost } \\
\text { period. }\end{array}$ & $\begin{array}{l}\text { Low intensity surface light is } \\
\text { automatic default during high cost } \\
\text { period. } \\
\text { Low energy cooking mode during } \\
\text { high cost period. }\end{array}$ & \\
\hline Waterheater & $\begin{array}{l}\text { Automatically sets } \\
\text { to use the lowest } \\
\text { amount of energy } \\
\text { during high-cost } \\
\text { hours. }\end{array}$ & $\begin{array}{l}\text { Conserve energy using eHeat }{ }^{\mathrm{TM}} \\
\text { mode, when the Geospring water } \\
\text { heater operates using just } 550 \\
\text { watts (vs. } 4500 \text { watts in standard } \\
\text { electric mode). }\end{array}$ & $\begin{array}{l}\text { Energy saving settings happen } \\
\text { automatically with no disruption } \\
\text { to hot water needs. But if extra } \\
\text { hot water is needed, consumer } \\
\text { can simply set the water heater to } \\
\text { standard electric mode. }\end{array}$ \\
\hline
\end{tabular}

Table 1.2-2. GE smart appliances with the ability to communicate through Nucleus with Brillion ${ }^{\mathrm{TM}}$ Technology (GE, 2012).

\section{The GE Brillion ${ }^{\text {TM }}$ Nucleus Energy Manager Meter has the following features:}

- Acts as the central nervous system for monitoring in-home electrical usage

- Shows energy use in $\mathrm{kWh}$ and in estimated dollars spent, to reveal trends over days, weeks and months-up to 3 years.

- Accumulates daily/monthly/yearly historical trends up to a span of three years

- Designed to adapt to expanding smart grid technology through online software enhancements

- Connects the in-home smart energy network directly to a personal computer (PC) through an ethernet connection or through an internet broadband router (cable-modem, digital subscriber line-modem, wireless, etc.)

- Operates in conjunction with local electricity providers' smart energy programs, where available

- Data is available via computer software. GE is also developing a smart phone app for viewing data.

- Currently available.

The GE Brillion ${ }^{\mathrm{TM}}$ HEM interface has the following features:

- Continuous energy use and cost information

- Gain insight into how much electricity you are consuming in both kilowatt hours $(\mathrm{kWh})$ and dollars.

- Time-based pricing

- Variable (time-of-use) pricing customers can see at-a-glance what price level they are currently paying.

- Historical energy usage

- Consumer can get energy consumption patterns of their usage by month, day and hour.

- Energy analysis

- Analysis tools on GE's energy display enables the consumer to look at their energy data for a defined period of time.

- Messages

- Utilities can communicate via the energy display, notifying the consumer with messages and reminders about utility maintenance, pricing changes, or critical conservation periods.

\subsubsection{Miele Appliances}

Miele@home network utilizes a Miele gateway to integrate household appliances into a domestic bus system. Using a personal computer connected to the internet or a mobile phone, it is possible to control and manage the networked appliances remotely. Miele appliances can also communicate and exchange 
data with the gateway using power line carrier technology. Miele appliances are also smart grid ready and are able to optimize energy use based on electricity rates. Using electricity rates data stored, the appliances can start automatically at the most economical time. The Miele system enables information to be centrally viewed and monitored at a single glance by the consumer. Miele appliances are also equipped with a self-diagnosis feature called 'InfoService' function. Through this function, appliances are able to send emails to owners regarding their status updates, instructions and error messages. If further help is required, the owners are required to contact customer service by phone. The email message to the owner includes tips on how to resolve issues. In case there is still a need for consultation, a customer service representative can solve the problem quickly and efficiently because of the detailed information available (Miele, 2012). Key features of Miele's smart appliances are listed in Table 1.2-3.

Miele appliances include energy saving features such as enabling communication between the cooking range and its exhaust hood. The exhaust hood collects and directly evaluates information about activities at the cooking range. This allows the hood to "automatically pre-empt occurrences on the cooking range and adjust extraction and lighting accordingly" (Miele, 2012).

Table 1.2-3. Key features of Miele Appliances relevant to CASHEM (Miele, 2012).

\begin{tabular}{|c|c|c|c|c|c|}
\hline Appliance & $\begin{array}{l}\text { Demand } \\
\text { Response } \\
\text { Features }\end{array}$ & $\begin{array}{c}\text { Operational Features } \\
\text { to Save Energy }\end{array}$ & \begin{tabular}{|c|} 
Operational \\
Features to \\
Control Energy \\
Use
\end{tabular} & $\begin{array}{l}\text { Self-Diagnostic } \\
\text { Features }\end{array}$ & User Interface \\
\hline Refrigerator & $\begin{array}{l}\text { Automatically } \\
\text { delays start } \\
\text { until energy } \\
\text { rates decrease }\end{array}$ & $\begin{array}{l}\text { Optimal storage } \\
\text { conditions are } \\
\text { maintained by alerting } \\
\text { the user when the } \\
\text { temperature rises, } \\
\text { electricity cuts out or } \\
\text { the door is left open. }\end{array}$ & None & $\begin{array}{l}\text { Status updates, } \\
\text { instructions and } \\
\text { error messages are } \\
\text { sent by e-mail } \\
\text { accompanied by } \\
\text { tips on how to } \\
\text { resolve them. }\end{array}$ & \multirow{4}{*}{$\begin{array}{l}\text { With SuperVision, } \\
\text { the current status } \\
\text { of networked } \\
\text { appliances can be } \\
\text { read in a central } \\
\text { location, for } \\
\text { example on the } \\
\text { display panel of } \\
\text { the oven. } \\
\text { The end of a } \\
\text { program cycle is } \\
\text { signaled with a } \\
\text { sound and an } \\
\text { image. }\end{array}$} \\
\hline \multirow[t]{2}{*}{$\begin{array}{l}\text { Clothes } \\
\text { Washer and } \\
\text { Clothes Dryer }\end{array}$} & \multirow[t]{2}{*}{$\begin{array}{l}\text { Automatically } \\
\text { delays start } \\
\text { until energy } \\
\text { rates decrease }\end{array}$} & $\begin{array}{l}\text { User can select washer } \\
\text { to wash with hot } \\
\text { water, rain water, and } \\
\text { well water. }\end{array}$ & $\begin{array}{l}\text { Energy } \\
\text { consumption } \\
\text { display educates } \\
\text { the user and } \\
\text { helps them } \\
\text { manage energy }\end{array}$ & \multirow[t]{2}{*}{$\begin{array}{l}\text { Status updates, } \\
\text { instructions and } \\
\text { error messages are } \\
\text { sent by e-mail } \\
\text { accompanied by } \\
\text { tips on how to } \\
\text { resolve them. }\end{array}$} & \\
\hline & & $\begin{array}{l}\text { The dryer is a heat } \\
\text { pump that can save up } \\
\text { to } 40 \% \text { primary energy }\end{array}$ & None & & \\
\hline Oven & $\begin{array}{l}\text { Automatically } \\
\text { delays start } \\
\text { until energy } \\
\text { rates decrease }\end{array}$ & $\begin{array}{l}\text { The exhaust hood } \\
\text { automatically adjusts } \\
\text { extraction and lighting } \\
\text { according to activities } \\
\text { at the cooking range. }\end{array}$ & None & $\begin{array}{l}\text { Status updates, } \\
\text { instructions and } \\
\text { error messages are } \\
\text { sent by e-mail } \\
\text { accompanied by } \\
\text { tips on how to } \\
\text { resolve them. }\end{array}$ & \\
\hline
\end{tabular}




\subsubsection{LG Appliances}

Smart grid enabled LG THINQ ${ }^{\mathrm{TM}}$ Technology deploys a smart meter to ensure that appliances operate with minimum amount of energy and during the time lowest electricity rates are available. LG's smart appliances are equipped with liquid crystal display (LCD) monitors that display daily, weekly or monthly data about energy consumption of appliances and their electricity costs. Smart phones and tablet PCs can be used to keep track of daily energy consumption and electricity usage as well as associated charges. Key features of LG's smart appliances are listed in Table 1.2-4.

Table 1.2-4. Key features of LG appliances relevant to CASHEM (LG, 2012).

\begin{tabular}{|c|c|c|c|c|c|}
\hline Appliance & $\begin{array}{l}\text { Demand } \\
\text { Response } \\
\text { Features } \\
\end{array}$ & $\begin{array}{l}\text { Operational } \\
\text { Characteristics } \\
\text { to save energy } \\
\end{array}$ & $\begin{array}{l}\text { Operational } \\
\text { characteristics to } \\
\text { control energy use } \\
\end{array}$ & $\begin{array}{l}\text { Self-Diagnostic } \\
\text { Features }\end{array}$ & $\begin{array}{l}\text { User } \\
\text { Interface }\end{array}$ \\
\hline Refrigerator & $\begin{array}{l}\text { Adjust } \\
\text { various } \\
\text { functions, } \\
\text { such as } \\
\text { defrost time } \\
\text { control - to } \\
\text { offer further } \\
\text { savings on } \\
\text { energy bills at } \\
\text { peak times }\end{array}$ & $\begin{array}{l}\text { Count and display } \\
\text { the frequency at } \\
\text { which homeowners } \\
\text { open the } \\
\text { refrigerator door, } \\
\text { giving them the } \\
\text { information they } \\
\text { need to save even } \\
\text { more energy }\end{array}$ & \multirow{3}{*}{$\begin{array}{l}\text { Deploys a smart } \\
\text { meter to ensure that } \\
\text { appliances use the } \\
\text { minimum amount of } \\
\text { energy at the least } \\
\text { expensive rates as } \\
\text { possible. } \\
\text { The LCD display on } \\
\text { LG's smart } \\
\text { appliances shows } \\
\text { daily, weekly or } \\
\text { monthly reports } \\
\text { detailing the } \\
\text { appliance's overall } \\
\text { levels of energy } \\
\text { consumption and } \\
\text { associated costs. } \\
\text { Daily totals for } \\
\text { electricity usage and } \\
\text { subsequent charges } \\
\text { will be accessible on } \\
\text { smartphones and } \\
\text { tablet PCs. }\end{array}$} & \multirow{2}{*}{$\begin{array}{l}\text { The consumer can } \\
\text { be alerted about } \\
\text { minor problems via } \\
\text { the display panel. } \\
\text { The appliance } \\
\text { includes a feature } \\
\text { by which the user } \\
\text { can press a } \\
\text { sequence of buttons } \\
\text { on the appliance. } \\
\text { This action triggers } \\
\text { a series of tones that } \\
\text { lets a technician } \\
\text { identify the issue } \\
\text { and how to correct } \\
\text { the problem. }\end{array}$} & \multirow{3}{*}{$\begin{array}{l}\text { HEM network } \\
\text { can be created } \\
\text { by interfacing } \\
\text { the appliance } \\
\text { with the users } \\
\text { smart phone of } \\
\text { tablet PC to } \\
\text { manage their } \\
\text { appliances. } \\
\text { Also, LG's } \\
\text { smart } \\
\text { appliances are } \\
\text { equipped with } \\
\text { LCD screens. }\end{array}$} \\
\hline $\begin{array}{l}\text { Clothes } \\
\text { Washer } \\
\text { and } \\
\text { Clothes } \\
\text { Dryer }\end{array}$ & \multicolumn{2}{|c|}{$\begin{array}{l}\text { Offers the ability to choose differing } \\
\text { wash load sizes that in turn alter the } \\
\text { spin time and total water used. This } \\
\text { saves both energy and money. }\end{array}$} & & & \\
\hline Oven & \multicolumn{2}{|c|}{$\begin{array}{l}\text { Using the Smart Grid, LG's ovens } \\
\text { offer three cost options - low, middle } \\
\text { and high - that take into account both } \\
\text { the duration of the cooking cycle and } \\
\text { varying costs of electricity and } \\
\text { energy consumption. }\end{array}$} & & $\begin{array}{l}\text { Consumers can } \\
\text { also diagnose their } \\
\text { washing machines } \\
\text { at home via a } \\
\text { downloadable } \\
\text { mobile application } \\
\text { on their } \\
\text { smartphone. }\end{array}$ & \\
\hline
\end{tabular}

LG appliances include a self-diagnosis feature called Smart Diagnosis ${ }^{\mathrm{TM}}$ (LG, 2012). This feature is expected to assist customer service representatives to quickly and efficiently troubleshoot mechanical issues over the phone. In addition to fault detection and diagnosis, appliances will also alert the owner for minor problems such as: refrigerator door was left open, ice-maker is switched off, or washing machine is off-balance. This alert would show on the display panel. LG is working on having the alert sent via a WiFi connection, on the consumer's smartphone or tablet PC (LG, 2012).

LG's smart grid-enabled refrigerators have capability to control features, such as saving money on electricity bills during peak times by controlling defrost time. LG refrigerators take advantage of a Smart Manager to let the owner know what they still have in the refrigerator or what should go on the grocery shopping list. This could minimize the number of times the homeowner opens the refrigerator's door. It even counts and displays the frequency at which the refrigerator door is opened, so the owner has extra 
information to help them save even more energy. The LG refrigerator will also be able to adjust its temperature and function settings to take advantage of varying energy rates on a daily basis (LG, 2012).

The LG Smart washer gives owners two choices to select. One is 'Recommend Time' and the other is 'Lowest Rate' (LG, 2012). If the user asks for a time recommendation, the washer will operate at the nearest most cost-effective time or immediately if there is no off-peak electricity option available anytime soon. If the second option is selected, then the algorithm in the washer would find the time when electricity rates are at their lowest and wait to run until then. If the user decides to override the washer settings and run the washer at a peak time, then the washing machine will just recommend the most energy-efficient cycle. LG's ovens have the capability to offer three cost options, which are low, middle and high. The oven's options are based on duration of the cooking cycle as well as the real-time cost of electricity (LG, 2012).

In addition to GE, Miele and LG appliances listed here, several other manufacturers (e.g., Samsung Electronics, Bosch, Electrolux, Whirlpool and Indesit ${ }^{1}$ ) list appliances with advanced features; however, at the time of writing this report, documentation of the ability of these appliances to collaborate with the smart power grid and with a variable utility price signal was not publically available.

\subsubsection{Appliances with Maximum Potential for HEM Integration}

In this section, smart appliances and residential equipment identified to be commercially available in the next 1-2 years are analyzed further based on a set of criteria to identify those with maximum potential for HEM integration. Table 1.2-5 contains a summary of features considered. Appliances are broken down into their sub-systems to identify their power consumptions and peak reduction resulting from shifting their load.

Table 1.2-5. Appliance features considered

\begin{tabular}{|c|c|c|c|c|c|c|}
\hline \multicolumn{2}{|c|}{ Appliance or Equipment } & $\begin{array}{l}\text { Total Energy } \\
\text { Shifted (W) in } \\
\text { One Cycle }^{(a)}\end{array}$ & $\begin{array}{c}\text { Duty Cycle } \\
(\%)\end{array}$ & $\begin{array}{c}\text { User Elasticity / } \\
\text { Delay } \\
\text { Acceptance }^{(b)} / \\
\text { (time of use }^{(c)} \text { ) }\end{array}$ & $\begin{array}{c}\text { Estimate } \\
\text { of Market } \\
\text { Size }{ }^{(d)} \\
\text { (Million) }\end{array}$ & $\begin{array}{c}\text { Annual } \\
\text { Energy Use } \\
\text { (kWh/yr) }^{(e)}\end{array}$ \\
\hline \multicolumn{2}{|l|}{ Pool Pump } & $\begin{array}{l}250-2,000 \\
\text { (water pumping) }\end{array}$ & $\mathrm{NA}^{(\mathrm{f})}$ & NA & 0.2 & $2242^{(\mathrm{g})}$ \\
\hline & Defrost & 400 & $\begin{array}{l}10 \text { min in } \\
18-36 \text { hour } \\
\text { period }\end{array}$ & \multirow[t]{2}{*}{$(15: 30-21: 00)$} & \multirow[t]{2}{*}{12.7} & \multirow[t]{2}{*}{1100} \\
\hline Refrigerator & Compressor & $450-700$ & $50 \%-20 \%$ & & & \\
\hline \multirow[t]{2}{*}{ Clothes dryer } & $\begin{array}{l}\text { Entire } \\
\text { device }\end{array}$ & $\sim 5,000$ & NA & \multirow[t]{2}{*}{$\begin{array}{l}25 \%-75 \% \\
(15: 30-21: 00)\end{array}$} & \multirow[t]{2}{*}{8.74} & \multirow[t]{2}{*}{1224} \\
\hline & Heater off & $\sim 1,800$ & NA & & & \\
\hline \multicolumn{2}{|l|}{ Clothes washer } & $350-500$ & NA & $\begin{array}{l}0 \%-75 \% \\
(16: 00-22: 00)\end{array}$ & 25.6 & 204 \\
\hline \multirow[t]{2}{*}{ Range } & $\begin{array}{l}\text { Oven } \\
\text { (heating } \\
\text { element) }\end{array}$ & $500-2,500$ & $25 \%$ & \multirow{2}{*}{$\begin{array}{l}0 \% \text { (during normal } \\
\text { signal) to } \\
10 \% \text { (during peak) } \\
(15: 30-21: 00)\end{array}$} & \multirow[t]{2}{*}{7} & \multirow[t]{2}{*}{432} \\
\hline & Cooktop & $\begin{array}{l}1,200-2,500 \\
\text { (depending on size } \\
\text { of the element) }\end{array}$ & $25 \%$ & & & \\
\hline
\end{tabular}

\footnotetext{
${ }^{1}$ Indesit Company $\operatorname{SpA}$ Fabriano - Ancona - Italy
} 
Table 1.2-5. (contd)

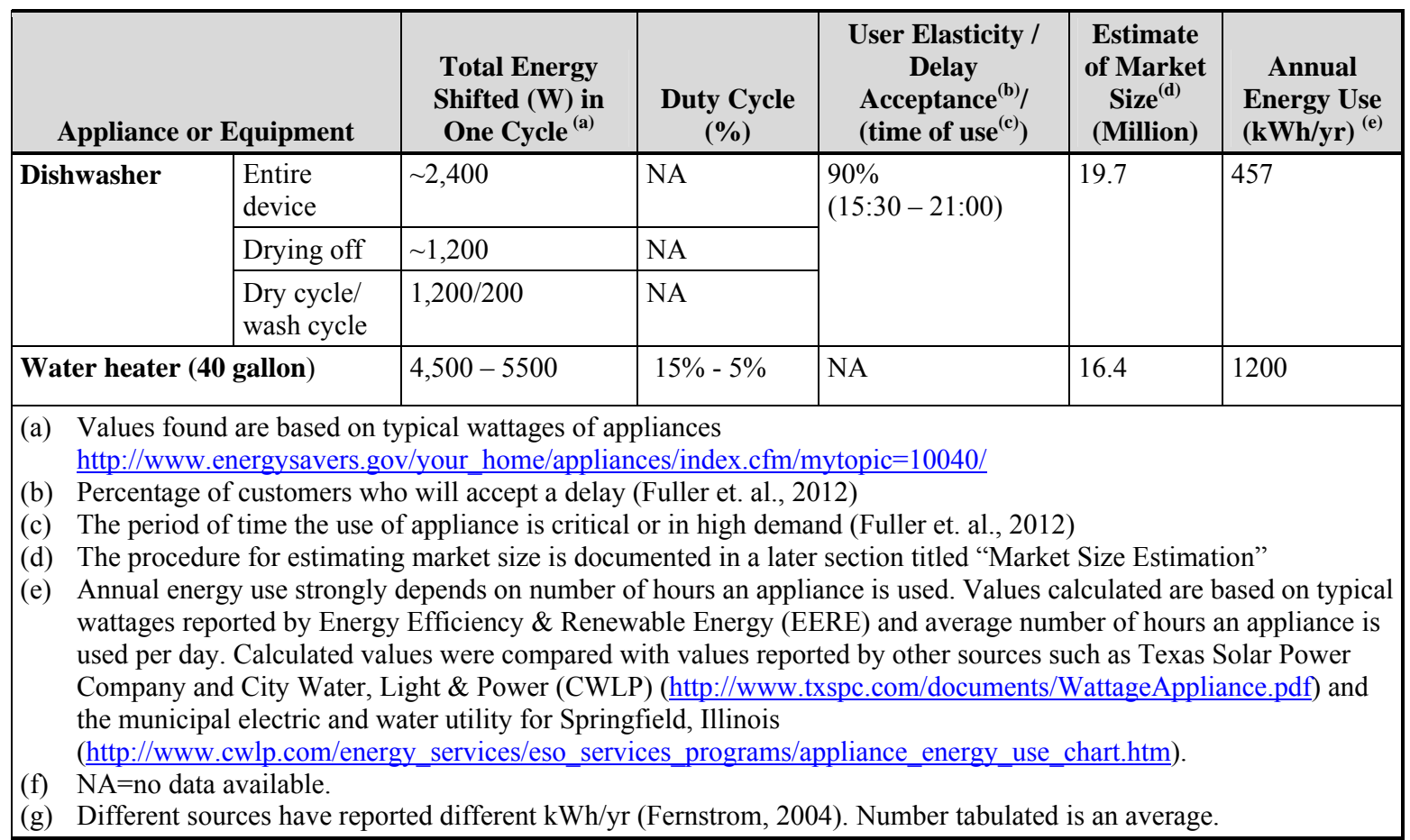

The following metrics are documented in Table 1.2-5:

- Total power (W) in one cycle - the quantity of power consumed by an appliance and its subsystems in one cycle.

- Duty cycle -the proportion of time a system or appliance runs while in operation. For example, the defrost cycle in a refrigerator is estimated to take place 10 minutes in a 24 hour period. Therefore, the duty cycle is $10 / 1440$ or $0.69 \%(\sim 1 \%)$ (Alouani, 1992).

- User elasticity and delay acceptance - a numerical value to determine what percentage of consumers are flexible or adaptable to shift their use of their electric appliances to hours demand is lower and electricity is cheaper. This is based on a modeling study at PNNL of GE appliances in GridLAB$\mathrm{D}^{\mathrm{TM}}{ }^{1}$. The study shows critical and high demand hours of use for each appliance and also the percentage of consumers (in this study) who were willing to accept delay, use energy saving mode of the appliance, or preferred to override all DR options (Fuller et. al., 2012).

- Estimate of market size - this includes estimations of the number of appliances that are reaching the end of their life expectancy and are ready for replacement (RECS, 2009) plus a forecast of the number of new residential constructions that need new appliances (U.S. Census Bureau, 2011).

- Annual energy use $[\mathrm{kWh} / \mathrm{yr}]$ - this is the average annual energy consumption of each appliance per year.

\footnotetext{
${ }^{1}$ GridLAB-D ${ }^{\text {TM }}$ is a power distribution system simulation and analysis tool developed by DOE at PNNL. (Chassin et al., 2008)
} 


\subsubsection{Appliance Load and Cycle Shifting}

In the study of appliances with demand response capability, in this section a summary of some demand response programs addressing home appliances from utility companies is documented. As an initiation to reduce energy consumption during peak times, these companies have developed programs that work by controlling the cycling interval of some home appliances. An example of some of these companies is included here to show how these programs work and how much savings can be expected by shifting demand of appliances specified. For example, Progress Energy (in Florida) has a program called 'EnergyWise Home', which works across the community to lower energy usage during peak times. Customer participation is free and includes the control switch/receiver. In a year, the customer can receive up to $\$ 147$ in bill credit. Table 1.2-6 lists a few utility companies in the U.S. that have residential demand management programs (note, this is not a comprehensive list).

Table 1.2-6. An example of utility companies with community scale HEM programs.

\begin{tabular}{|c|c|c|c|c|c|}
\hline Company & $\begin{array}{l}\text { Name of } \\
\text { the } \\
\text { Program }\end{array}$ & Location & $\begin{array}{c}\text { Cycling } \\
\text { Interval or } \\
\text { Control } \\
\text { Periods }\end{array}$ & Savings & $\begin{array}{l}\text { Appliance/ } \\
\text { Equipment } \\
\text { Controlled }\end{array}$ \\
\hline Progress Energy ${ }^{(a)}$ & EnergyWise & Florida & Not identified & $\begin{array}{l}\text { Up to } \$ 147 \text { credit } \\
\text { (annual) }\end{array}$ & $\begin{array}{l}\text { Water heater, pool } \\
\text { pump, HVAC }^{(\mathrm{g})}\end{array}$ \\
\hline Alliant Energy ${ }^{(b)}$ & $\begin{array}{l}\text { Appliance } \\
\text { Cycling }\end{array}$ & $\begin{array}{l}\text { Iowa and } \\
\text { Wisconsin }\end{array}$ & $\begin{array}{l}\text { Every } 15 \text { min }(1 \\
\text { pm }-7 \mathrm{pm})\end{array}$ & $\$ 45$ credit (annual) & $\begin{array}{l}\text { HVAC and water } \\
\text { heater }\end{array}$ \\
\hline DTE Energy ${ }^{(c)}$ & CoolCurrents & Ohio & Not identified & $\begin{array}{l}\text { Up to } 20 \% \text { annual } \\
\text { saving on AC bill } \\
\text { (there is a } \$ 1.95 \\
\text { monthly charge) }\end{array}$ & HVAC \\
\hline $\begin{array}{l}\text { Price Electric } \\
\text { Cooperative }^{(\mathrm{d})}\end{array}$ & $\begin{array}{l}\text { Water heater } \\
\text { thermal } \\
\text { storage } \\
\text { program }\end{array}$ & $\begin{array}{l}\text { Phillips, } \\
\text { WI }\end{array}$ & $\begin{array}{l}4 \text { hour control } \\
\text { program }\end{array}$ & $\begin{array}{l}\$ 50 \text { - } \$ 350 \text { rebates } \\
\text { depending on the } \\
\text { size of water heater }\end{array}$ & Water heater \\
\hline $\begin{array}{l}\text { Dairyland Power } \\
\text { Cooperative/Jackson } \\
\text { Electric Cooperative }^{(\mathrm{e}, \mathrm{f})}\end{array}$ & $\begin{array}{l}\text { Water heater } \\
\text { program }\end{array}$ & WI & $\begin{array}{l}\text { Not identified/ } \\
\text { limited to } 6 \\
\text { hours per day }\end{array}$ & $\$ 3$ credit (monthly) & Water heater \\
\hline \multicolumn{6}{|c|}{$\begin{array}{l}\text { (a) https://www.progress-energy.com/florida/home/save-energy-money/energy-efficiency-improvements/energy- } \\
\text { wise/index.page } \\
\text { (b) } \underline{\mathrm{http} / / \text { www.alliantenergy.com/SaveEnergyAndMoney/AdditionalWaysSave/ApplianceCycling/index.htm }} \\
\text { (c) } \underline{\mathrm{http} / / \text { www.dteenergy.com/residentialCustomers/saveEnergy/heatingCooling/interruptibleRate.html }} \\
\text { (d) http://www.price-electric.com/waterheat.htm } \\
\text { (e) http://docs.jackelec.com/programs/Water\%20Heater\%20Brochure.pdf } \\
\text { (f) http://www.jackelec.com/programs/water_heater_program } \\
\text { (g) } \mathrm{HVAC=heating,} \mathrm{ventilating,} \mathrm{and} \mathrm{air} \mathrm{conditioning.}\end{array}$} \\
\hline
\end{tabular}

No literature has been found on a utility company controlling cycling interval of other appliances, e.g., refrigerators, washers, dryers and dishwashers. In other words, utilities have not yet developed a program to interrupt or delay the defrost cycle of a refrigerator, or the washing cycle of a dishwasher, or a clothes dryer. However, there is more research being conducted related to load modeling of home appliances (Fuller et. al., 2012), which HEMs projects can take advantage of to build devices that can help consumers make more informed decisions about time of use of their appliances.

Buildings will have a more interactive role in the structure of modern grid, and as a result, there is more need to study and understand the behavior of building loads. One advantage of modeling and 
understanding the loads in buildings is that based on shapes and behavior of the loads, we can decide when cycling interruption is more feasible while the appliance is in operation. For example, Figure 1.2-1 represents a multi-state load model of a dishwasher, which shows the load shape at different cycles and states. During state 1, there is no energy consumption and the dishwasher is in the "off" state. State 2 is a "control only" state, i.e., the motor and coil are powered off automatically, the appliance is in transition from one state to another, and energy consumption is very close to zero. Therefore, it might be possible to "pause" the appliance for the purpose of DR when it is in State 2. Similar features in the operation profile of other appliances may be found by examining their load shapes documented in Appendix A.

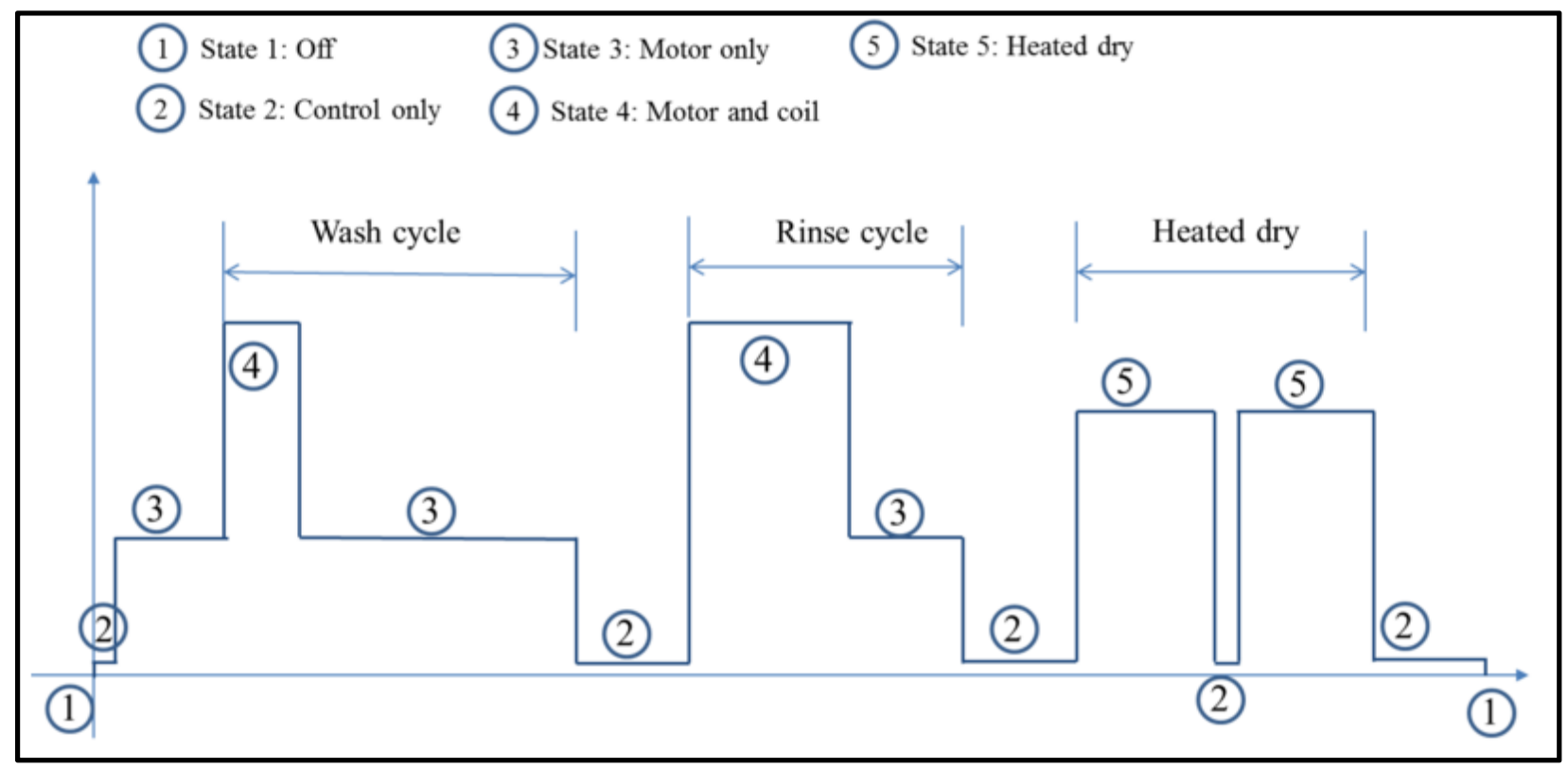

Figure 1.2-1. Multi-state load model of a dishwasher developed in GridLAB-D. These states are determined based on level of power demand (GridLAB-D, 2012).

\subsubsection{Market Size Estimation}

For this study, we assumed that the majority of consumers would consider replacing their appliances with a new appliance if the current appliance is reaching the end of its life span. Furthermore, we recognize that the consumer will only buy a high price smart appliance if they can see some monetary or other benefits. The _National Association of Homebuilders_NAHB) and other home appliance inspection companies (e.g., ATD Home Inspection) have undertaken studies to determine the approximate life expectancy of the majority of household appliances. In these studies they interviewed manufacturers, trade associations, researchers, or used their own historic data to determine the life expectancy of the appliances. Table 1.2-7 shows a summary of NAHB's study of life expectancy of home appliances as well as an average of what was reported from other studies of expected lifespan of appliances. 
Table 1.2-7. Life expectancy of appliances.

\begin{tabular}{|l|c|c|}
\hline \multicolumn{1}{|c|}{ Appliance } & \multicolumn{1}{|c|}{$\begin{array}{c}\text { Expected Number of Years } \\
\text { Reported by NAHB }\end{array}$} & $\begin{array}{c}\text { Average Number of Years from } \\
\text { Other Studies }\end{array}$ \\
\hline Pool pump & Not reported & $5-12$ \\
\hline Range (electric) & 13 & $8-15$ \\
\hline Refrigerator & 13 & $8-14$ \\
\hline Clothes washer & 10 & $5-15$ \\
\hline Clothes dryer (electric) & 13 & $8-14$ \\
\hline Dishwasher & 9 & $7-12$ \\
\hline Water heater (electric) & 11 & $10-11$ \\
\hline
\end{tabular}

Based on the data in Table 1.2-7, the potential market size in the U.S. for clothes washers, dishwashers, and water heaters older than 10 years of age and refrigerators, ranges, and clothes dryers older than 15 years old was determined. According to Residential Energy Consumption Survey (RECS, 2009) data, number of appliances that fall in this category and should therefore be ready for replacement in near future are: 12.4 million refrigerators, 7.1 million second refrigerators, 25.3 million clothes washers, 10.7 million clothes dryers, 19.4 million dishwashers and 42.1 million water heaters. It should be noted that there are a total of 113.6 million water heaters installed and out of which 43.7 million are electric. Approximately $39 \%$ of water heaters currently installed are electric. Therefore, out of 42.1 million water heaters that are older than 10 years of age, about 16-17 million are electric and ready for replacement. RECS data also shows that about $79.5 \%$ of clothes dryers currently installed are electric. Therefore, out of 10.7 million clothes dryers that are reaching their maximum life span, about 8.5 million are electric. Unfortunately, RECS has no data on age of electric ranges. Total number of electric ranges in 2009 was reported as 61.9 million, which is about $60 \%$ of total ranges. The trend for potential appliance replacement (Figure 1.2-2) shows that on average about $11 \%$ of those appliances with life expectancy of $\sim 15$ years are potentially ready for replacement. Since a range's life expectancy is also around 15 years, we estimate that about 11 percent of them have replacement potential.

Pool pumps and motors have an average life span of about ten years and there are about 120,000 units ready for replacement each year plus 22,700 new sales (Fernstrom, 2004). This adds up to 142,700 units in 2004 with an annual growth rate of about $1.7 \%$.

According to United States Census Bureau (2012), there were 306,000 new constructed homes sold in 2011 and we assume all of those need a new refrigerator, clothes washer, and dishwasher. The data show that $79.5 \%$ of new homes built will have new electric clothes dryer, $60 \%$ will have electric ranges, and $39 \%$ would install a new electric water heater.

Table 1.2-8 and Figure 1.2-3 show a summary of the number of appliances that have replacement potential in addition to the number of appliances installed in new homes. Appendix B shows more details on the number of appliances in the U.S. based on age of appliances and year of construction of homes. Graphs shown in Appendix B are used to ascertain maximum potential for smart appliance replacement in the near future. 


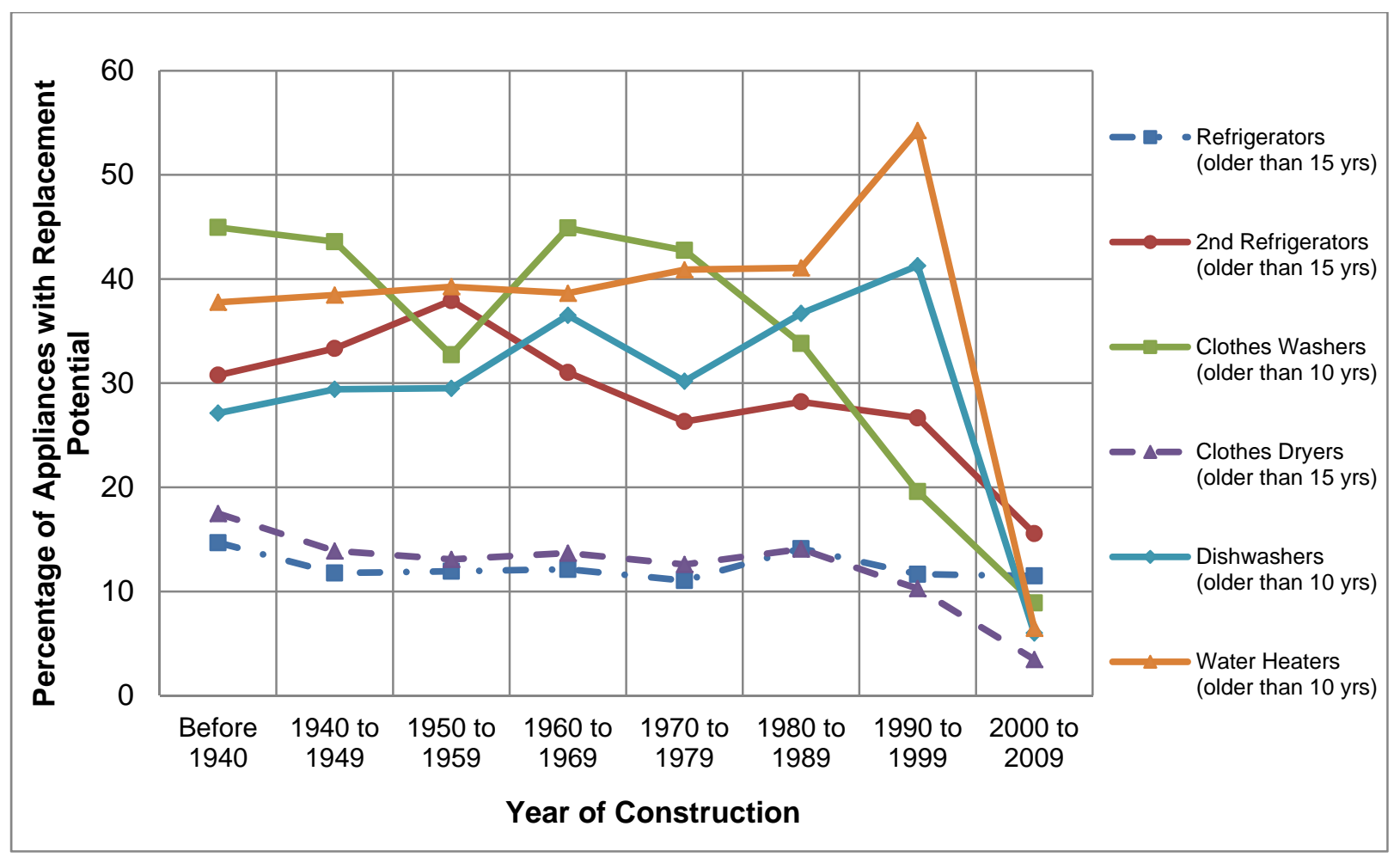

Figure 1.2-2. Replacement trend of appliances based on year of construction of homes. This was used to estimate market size for cooking ranges that have replacement potential by looking at trends for other appliances.

Table 1.2-8. Estimate of market size of appliances and pool pumps.

\begin{tabular}{|l|l|c|c|}
\hline Appliance/Equipment & Units Ready for Replacement & New Units & Total Units (in 2009) \\
\hline Refrigerator & 12.4 million (11\% of total) & 306,000 & $12,706,000$ \\
\hline Second refrigerator & 7.1 million $(27 \%$ of total) & $70,035^{(\text {a) }}$ & $7,170,035$ \\
\hline Range & 6.8 million (11\% of total) & 183,600 & $6,983,600$ \\
\hline Clothes washer & 25.3 million (27\% of total) & 306,000 & $25,606,000$ \\
\hline Clothes dryer & 8.5 million (11\% of total) & 243,270 & $8,743,270$ \\
\hline Dishwasher & 19.4 million (28\% of total) & 306,000 & $19,706,000$ \\
\hline Electric water heater & 16.25 million (37\% of total) & 118,129 & $16,368,129$ \\
\hline Pool pump & 120,000 & 22,700 & 142,712 \\
\hline (a) About 22\% of total homes in the U.S. have second refrigerator (RECS, 2009) \\
\hline
\end{tabular}




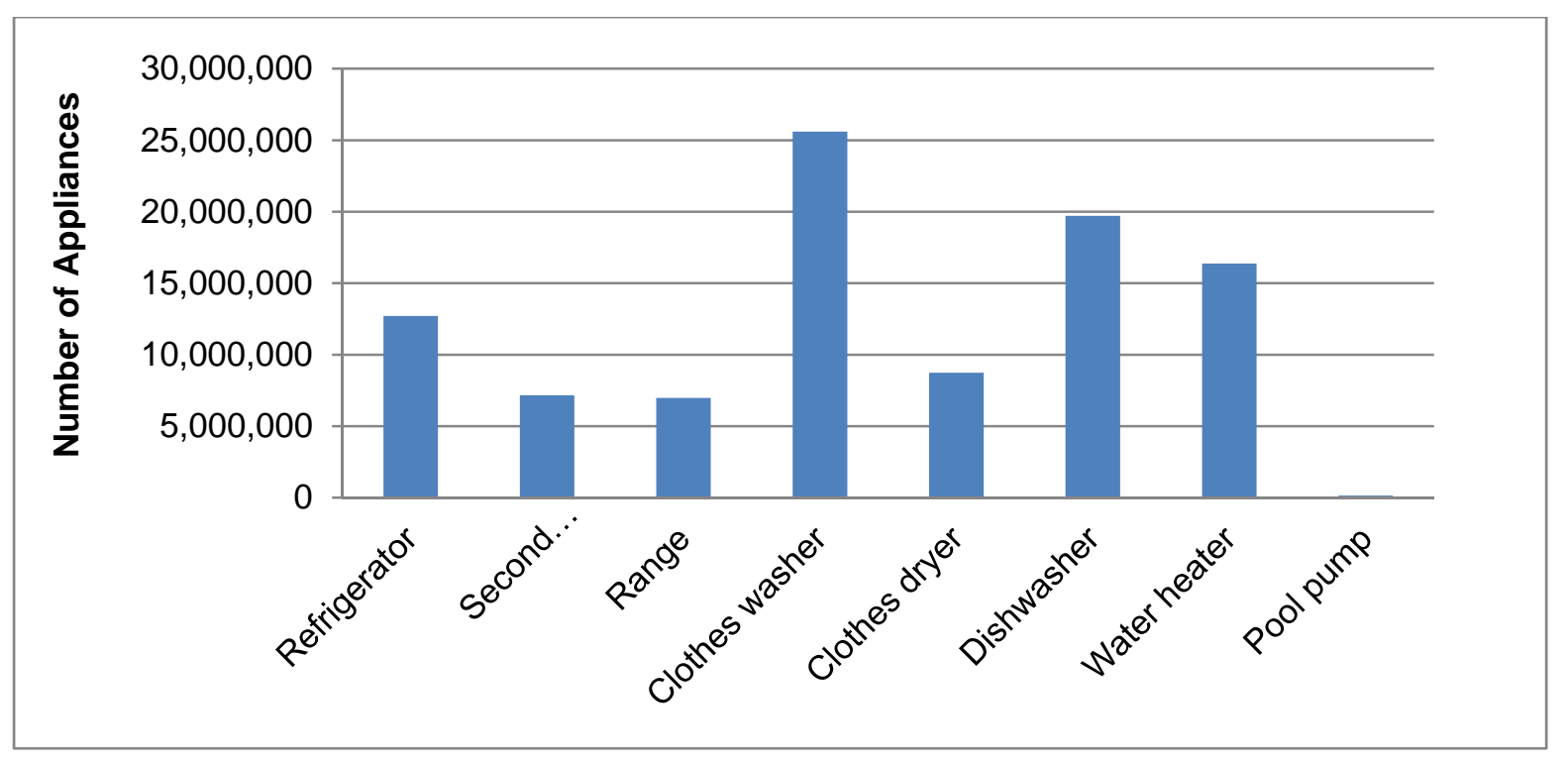

Figure 1.2-3. Estimate of number of appliances with replacement potential.

\subsubsection{Demand Reduction Potential of Smart Appliances}

An estimation of the minimum and maximum amount of energy that can be shifted in one cycle by a 'typical' smart appliance is shown in Table 1.2-9 and plotted in Figure 1.2-4. The calculation is based on multiplying the estimated market size for smart appliances by the DR potential (i.e. the megawatts of energy that can be shifted). These results are based on typical wattage of appliances reported by EERE (2011) as well as the estimation of market size given in Table 1.2-9 with the assumption that all appliances estimated in the market size analysis will be replaced with smart appliances. This first-pass estimate does not take into account the time of use of the appliances or the number of units operational at a given time. For example, the table shows that the load shifting capability, based on appliance energy demand, of the dishwasher is on-par with the clothes dryer. However, dishwasher loads tend to peak late in the evening (because of automatic settings), while clothes dryers tend to peak around noon or on weekends.

Table 1.2-9. Estimate of demand shift potential by smart appliances in one operation cycle.

\begin{tabular}{|c|c|c|c|c|c|c|}
\hline & Appliance & $\begin{array}{c}\text { Minimum } \\
\text { Wattage }\end{array}$ & $\begin{array}{c}\text { Maximum } \\
\text { Wattage }\end{array}$ & $\begin{array}{l}\text { Estimate of } \\
\text { Smart Units }\end{array}$ & $\begin{array}{c}\text { Estimate of } \\
\text { Minimum Total } \\
\text { Demand Shifted } \\
\text { (MW) }\end{array}$ & $\begin{array}{c}\text { Estimate of } \\
\text { Maximum } \\
\text { Total Demand } \\
\text { Shifted } \\
\text { (MW) }\end{array}$ \\
\hline \multicolumn{2}{|l|}{ Pool Pump } & 250 & 2000 & 142,712 & 36 & 285 \\
\hline \multirow[t]{2}{*}{ Refrigerator } & Defrost & 400 & 400 & $12,706,000$ & 5,082 & 5,082 \\
\hline & Compressor & 450 & 700 & $12,706,000$ & 5,718 & 8,894 \\
\hline \multirow[t]{2}{*}{ Clothes Dryer } & Entire device & 1800 & 5000 & $8,743,270$ & 15,738 & 43,716 \\
\hline & Heater off & 1800 & 1800 & $8,743,270$ & 15,738 & 15,738 \\
\hline \multicolumn{2}{|c|}{ Clothes Washer } & 350 & 500 & $25,606,000$ & 8,962 & 12,803 \\
\hline \multirow[t]{2}{*}{ Range } & Oven (heating element) & 500 & 2500 & $6,983,600$ & 3,492 & 17,459 \\
\hline & Cooktop & 1200 & 2500 & $6,983,600$ & 8,380 & 17,459 \\
\hline Dishwasher & Entire device & 1200 & 2400 & $19,706,000$ & 23,647 & 47,294 \\
\hline \multicolumn{2}{|c|}{ Electric water Heater } & 4500 & 5500 & $16,368,129$ & 73,657 & 90,025 \\
\hline
\end{tabular}


Based on results shown in Figure 1.2-4 residential water heaters have a greater potential for reducing demand during peak electrical demand than other appliances. This is corroborated by other studies (Fuller et. al., 2012), which reveal similar results. Furthermore, these results are in line with DOE's residential water heater load control and electric thermal storage programs (DOE, 2012).

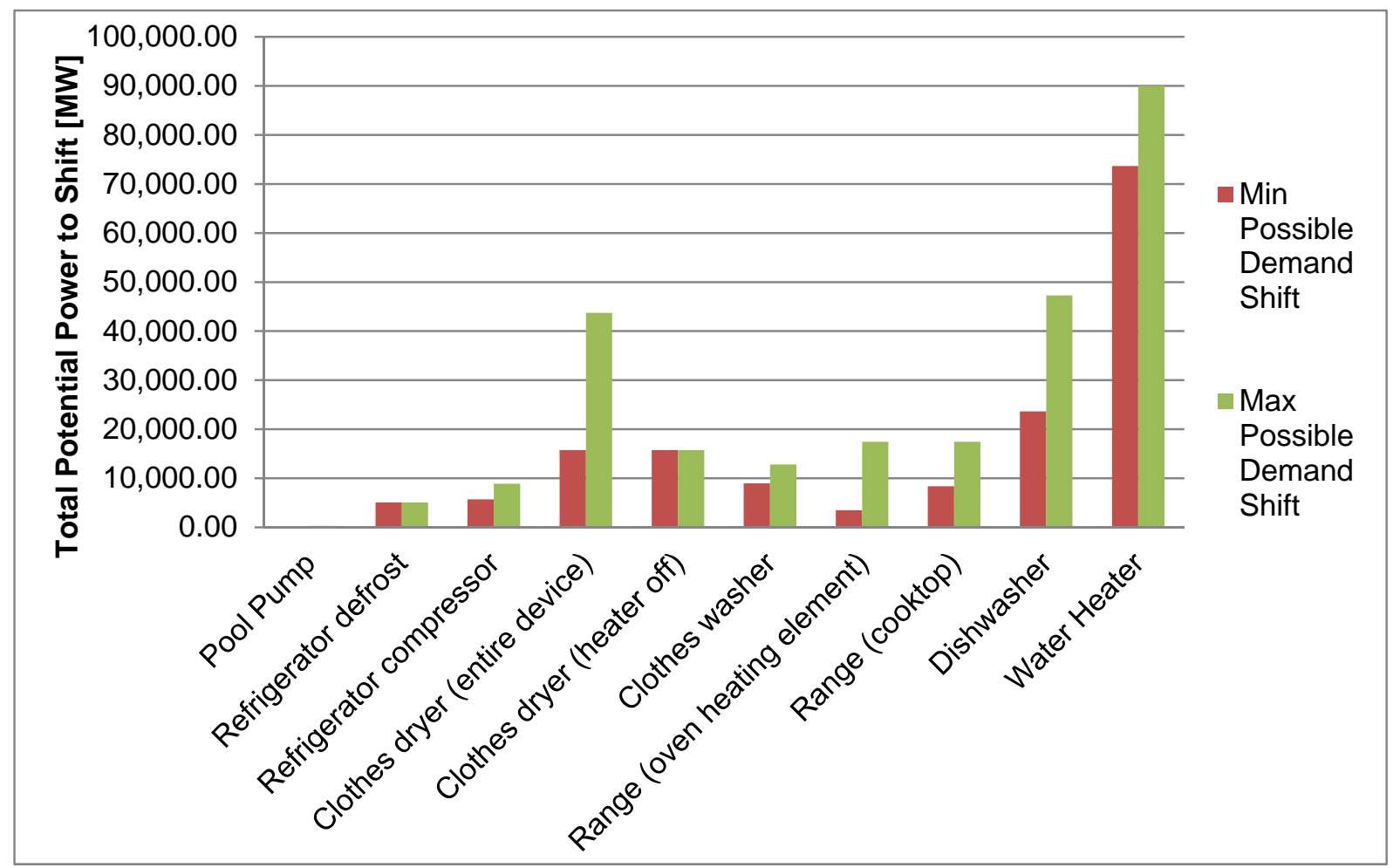

Figure 1.2-4. Minimum and maximum appliance demand shift possible.

Figure 1.2-4 also shows that after water heaters, smart dishwashers are second in the amount of demand load shift. In addition to this, Table 1.2-5 shows that $90 \%$ of participants in a study done by PNNL (Fuller et. al., 2012) are willing (i.e., are elastic) to shift their dishwasher cycle to off-peak hours.

Furthermore, the load shape of the dishwasher (Figure 1.2-1) indicates a potential for the HEM integration because there are several 'control' states (before wash cycle, before rinse cycle and before heated dry cycle) that may allow the HEM to pause the dishwasher cycle, and then move to the next state when there is a lower price signal.

The load models of other appliances (shown in Appendix A) reveal that the cooking range and clothes dryer do not have these 'control' states. However, clothes washers do have 'control' states before wash, rinse, and spin cycles, but pausing the operation between these cycles may create the potential for mold in wet clothes.

Based on Figure 1.2-4, pool pumps have a low total potential for demand load shifting because of their low numbers across the nation. However, those residences that have pool pumps can shift their usage time to off-peak hours, thereby shifting approximately $2 \mathrm{~kW}$ of demand load. Therefore, HEM integration can be an advantage in controlling pool pumps. 


\subsubsection{Conclusion}

The widespread deployment of DR enabled home appliances (e.g., smart appliances) is expected to provide significant potential reduction in the demand of electricity during peak hours. The main objective of this task was to analyze and identify DR enabled appliances (i.e., smart appliances) that have the maximum potential for HEM integration. This analysis is based on an estimate of future market size, total energy that can be shifted during peak electrical demand hours, and technical potential of appliances to respond to price signals. Conclusions about the effectiveness of HEM integrated appliances in reducing electrical demand have been drawn and a ranking of appliances are presented in Table 1.2-10

Table 1.2-10. Rank order of appliances based on maximum potential for HEM integration.

\begin{tabular}{|c|l|l|}
\hline Rank & Appliance & \multicolumn{1}{c|}{ Summary of reasons } \\
\hline 1 & Water heater & $\begin{array}{l}\text { High power use } \\
\text { Maximum load shift of all appliances } \\
\text { High user elasticity } \\
\text { Demand shift can be undertaken with minimal capital cost (investment by the utility) } \\
\text { and little impact on residents given the size of the water heater (thermal capacity) and } \\
\text { time duration of the shift. }\end{array}$ \\
\hline 2 & Dishwasher & $\begin{array}{l}\text { Significant penetration of appliances in residences and therefore a high potential for } \\
\text { load shifting } \\
\text { High user elasticity } \\
\text { Load shape allows cycle interruption and pausing to shift load } \\
\text { May provide additional savings due to shift in electric water heater demand }\end{array}$ \\
\hline 3 & Pool pump & $\begin{array}{l}\text { High power use/unit, therefore potential for large demand shifting } \\
\text { High user elasticity } \\
\text { Low numbers across the nation }\end{array}$ \\
\hline 4 & Clothes dryer & $\begin{array}{l}\text { Moderate user elasticity } \\
\text { High power use }\end{array}$ \\
\hline 5 & Clothes washer & $\begin{array}{l}\text { Moderate user elasticity } \\
\text { Low power use } \\
\text { May provide additional savings due to shift in electric water heater demand }\end{array}$ \\
\hline 6 & Refrigerator & $\begin{array}{l}\text { High user elasticity } \\
\text { Relatively low power use }\end{array}$ \\
\hline
\end{tabular}




\subsection{Onsite Electricity, Heat Generators and Storage for Residential Applications}

This section documents a literature review of on-site generation technologies that are viable and appropriate for single-family residential applications. The most promising on-site electricity and heat generators and storage devices understood to be more widely available and their potential for HEM integration are identified. The focus of this task is to identify the most capable technologies that can be simply implemented into a HEM system.

A comprehensive literature aggregation and review of research papers was conducted. These research papers focus on on-site generation technologies for residential buildings, and their ability to communicate with the CASHEM and HEM infrastructures. The papers included are those that are publically available. After the information was assembled, it was categorized into a spreadsheet that is embedded below as part of this document. This spreadsheet organizes the available information into the following subsections: Residential On-site Generation and General Technology Information.

An Excel file was prepared and delivered to Honeywell containing two tabs. Tab A was a collection of research papers detailing residential and commercial on-site generation projects that have been proposed and/or implemented. These papers are labeled in descending order in terms of the date of final publication. Specific information on each project (e.g., installed capacity, price, and control systems) where available, is categorized for further reference within the table. A brief summary of each paper is also included in the table.

Tab B was a summary of information collected on commercially available on-site generation equipment that is applicable to single-family residences. Specific information extracted from the manufacturer website includes quantity of electric and heat output, fuel used, as well as installation space required. Where possible, a $\$ / \mathrm{kW}$ number is calculated and method documented.

\subsubsection{Characterization of Energy Use and Load in a Home}

The Residential Energy Consumption Survey (RECS) reports that the total United States energy consumption in homes has remained relatively stable for many years as increased energy efficiency has offset the increase in the number and average size of housing units. The average single-family residence is reported to consume approximately 90 million British thermal units (Btu) (26,352 kWh) in 2009 based on RECS. This continues the downward trend in average residential energy consumption of the last 30 years. Despite increases in the number and the average size of homes, plus increased use of electronics, improvements in efficiency for space heating, air conditioning, and major appliances have all led to decreased consumption per single-family residence. Newer homes also tend to feature better insulation and other characteristics, such as double-pane low-e windows, that improve the building envelope and reduce heating and cooling energy consumption.

The annual energy consumption of $26,352 \mathrm{kWh}$ indicated a $3 \mathrm{~kW}$ annual average demand (based on 8760 hours/year). We used the diversity factor (Hendron \& Engebrecht, 2010) in a home (peak load profile) to estimate the peak load that an on-site generation system must be able to serve. A system for a typical single-family home should have capacity of 5 to $10 \mathrm{~kW}$ to satisfy the peak demand. 


\subsubsection{Residential On-Site Generation Technologies}

Residential on-site generation technologies considered include: combined heat and power (CHP) systems that are fuel cell based, internal combustion engine based, as well as microturbine based. Residential scale wind turbines and roof-top solar photovoltaic (PV) are also examined. The examination criteria for these systems are as follows:

1. Ease of integration: Capability to be integrated with other electric sources supplying a singlefamily residence such as another power supply (e.g., a system with microturbine, PV as well as an electric utility supply), a storage system (e.g., battery) and a HEM that includes the management of appliances with DR capability.

2. Capability to be dispatched: The ability for the on-site generation technology to be controlled (i.e., to be turned on and off as determined by the HEM) and implemented within the utility grid.

3. Uninterruptible power supply (UPS) capability: Ability for the technology to be connected as a UPS, i.e., an electrical device that provides emergency power when the input power source fails.

4. Response time: The time the system takes to react and reach steady-state operating conditions when required to supply power.

5. Total capital cost: Total cost of the on-site generation equipment including ancillary equipment required for integration.

6. Adequacy: The ability of the generation technology to supply the required electrical power demand.

7. Security: The ability of the on-site generation system to tolerate sudden disturbances or unexpected losses in sub-systems. For example, this includes the ability of an internal combustion generator to automatically shut down if low oil pressure causes a high engine temperature alarm to sound.

Current documentation on applications of on-site generation systems focuses primarily on commercial buildings. Only five of the papers document an on-site generation capacity that is sized to power a single-family home. Due to the high initial investment required to install these generation systems, only two of the papers, (Higbee, 2005) and (Ruangpattana, 2011), detail an on-site generation system installed within a residential setting. In three papers, hybrid on-site generation systems are documented where PV arrays and wind turbines are coupled together to create a $20 \mathrm{~kW}-13 \mathrm{MW}$ zeroemission energy generation system for a 500 unit multi-family complex. Though these technologies are efficient, they are not economically feasible on a single-family residential scale at this time, and have little potential to be controlled for DR applications. Little information is given in the literature on the control systems implemented for residential on-site generation integrated with HEM for the system to function as a UPS.

\subsubsection{Internal Combustion Generators based Residential CHP Systems}

Based on the literature review, the most commonly used on-site generation systems are CHP internal combustion generators. These products offer a low cost, controllable means for on-site generation and when combined with a battery source have the capability to function as effective UPS systems. 
Commercially available CHP internal combustion generator system (e.g. residential cogeneration units available from Honda Power Products ${ }^{1}$ ) may be fueled by natural gas or liquid propane. These single-family residential gas cogeneration units utilize compact engine technology and sine wave inverter power generation technology to generate electricity with the gas engine and simultaneously recover waste heat, providing homes with hot water and heat. The manufacturer of this system states that the recovered waste heat in the form of hot water from the generator system is connected to the boiler / hot water tank provided by the hot water supply equipment manufacturer. The unit includes a control panel which allows for the input of settings without the use of maintenance tools, making installation easier. A grid monitoring system with dual power outage detection function constantly monitors the power grid voltage waveform to detect outages and safely shut down the system should power be lost. Currently, no information was found detailing the integration of this on-site generator with a DR capable HEM.

\subsubsection{Fuel Cell based Residential CHP Systems}

Advanced generation systems were also evaluated including research papers (Eguchi, 2009), (Armstrong, 2005), and (Delaware County Electric Cooperative, Inc., 2007). These papers detail specific information of fuel cell technologies and their implementation in single-family residences as on-site generation capacity. Fuel cells and microturbines have been implemented in some areas for single-family residences as well as for multiple single-family residences. Within the research paper collection, a total of nine papers were gathered that detailed fuel cell and/or microtubines as on-site generation systems. Four of the nine papers detailed natural gas fuel cells being used within a residential setting with power generation capacities from $2.5 \mathrm{~kW}$ to $50 \mathrm{~kW}$.

Several fuel cell systems on a single-family residential scale were found to be commercially available. One manufacturer ${ }^{2}$ was found that produces fuel cells with $1000 \mathrm{~W}$ and $5000 \mathrm{~W}$ nominal electric power using proton exchange membrane (PEM) technology. The membrane on the fuel cell stack converts hydrogen into electric power with water as the byproduct. Hydrogen is produced on-site by an ancillary unit that process natural gas into hydrogen. These power generators produce electric power at $110 \mathrm{~V}$ or $230 \mathrm{~V}$ AC and $12 \mathrm{~V}, 24 \mathrm{~V}$ or $48 \mathrm{DC}$ (other voltages on request). They are designed to be used as UPS, back-up power systems, and as stand-alone power generators providing electricity to single-family residences, in grid back up, as solar hybrid, in telecommunication towers or military applications or remote applications.

Manufacturers claim that these units are quiet in operation, small in size and light weight, produce zero-emissions, minimal maintenance, reliable, stable and have quick start operation. They state that these products are integrated residential fuel CHP products ${ }^{3}$. This product is designed to replace a conventional boiler, using the same natural gas, water and electrical connections and with similar installation and maintenance requirements.

Residential scale fuel cell products ${ }^{4}$ are commercially available that are advertised to have a wide operating range to be used to balance electricity from intermittent renewable sources such as solar and

\footnotetext{
${ }^{1}$ Honda Power Products. http://world.honda.com/power/cogenerator/

2 TROPICAL S.A., Athens, Greece. http://www.fuelcellmarkets.com/products_and_services/3,1,7159,17,28240.html? subsite $=7159$ \&language $=1$

${ }^{3}$ CeresPower, UK. http://www.cerespower.com/

${ }^{4}$ Ceramic Fuel Cells, Australia. http://www.cfcl.com.au/
} 
wind. This unit is sized to deliver approximately 13,000 kilowatt-hours of electricity per year. Waste heat from this fuel cell can be recovered to provide 200 liters ( $\sim 53$ gallons) of domestic hot water per day. This increases total system efficiency to approximately 85 per cent.

\subsubsection{Residential Scale Wind Turbine Generators}

Commercial single-family residential scale products ${ }^{1}$ are available that when connected to the grid can provide $5-10 \mathrm{~kW}$ of electricity. These small wind systems currently qualify for a $30 \%$ Federal Tax Credit as well as for accelerated depreciation. Advanced wind turbines such as those that utilize a system of magnets and stators surrounding the outer ring enable higher electric outputs from smaller sizes, e.g., $1,500 \mathrm{kWh}$ from a turbine that measures 6 feet in diameter. The model WT6500 wind turbine from Honeywell falls in this category.

\subsubsection{Photovoltaic Systems}

Photovoltaic (PV) panels are common for residential applications and are available from multiple national and international manufacturers. Although not explicitly explained in this text, commercial polycrystalline PV products are included in the attached Excel spreadsheet (at the end of this document) in Tab B.

\subsubsection{Battery Storage Systems}

Residential energy storage systems include battery and hot water within a water heater. In (NREL, 2002), the authors describe features of a system where power generated by on-site generation system is stored within batteries. The size and number of batteries is dependent on the energy needs of the home and the potential energy being supplied by the generation system. However, batteries are reported to be the most expensive component of the renewable energy system in an off-grid home due to maintenance and replacement costs.

Pike Research's report, “Community and Residential Energy Storage” (Pike Research, 2012), assesses the market opportunity for battery-based energy storage systems in community and residential deployments. This report states that total worldwide installed capacity for community and residential energy storage systems will reach 3,000 megawatts by 2022, with an annual market value of $\$ 872$ million driven by the expansion of distributed solar PV capacity, the adoption of plug-in electric vehicles, and the spread of dynamic pricing programs.

In (Tuffner \& Kintner-Meyer, 2011), the authors document the findings from a study to examine the use of electric vehicles to mitigate imbalances in renewable energy generation. This report explores the usage of two different charging schemes - first where charging is varied to absorb the additional imbalance from the wind generation, but never feeds power back into the grid. This scenario is highly desirable to automotive manufacturers, who harbor great concerns about battery warranty if vehicle-togrid discharging is allowed. The second strategy, varies not only the charging of the vehicle battery, but also can vary the discharging of the battery back into the power grid. The authors report that this scenario is currently less desirable to automotive manufacturers.

\footnotetext{
${ }^{1}$ Bergey Wind Power, USA. http://www.bergey.com/
} 


\subsubsection{Hot Water Storage Systems}

DOE's residential water heater load control and electric thermal storage programs (DOE, 2012) have encouraged utilities and water heater programs to work on DR technology. Some of these programs offered by utilities were listed in Table 1.2-5.

Consumers participate in water heater thermal storage programs by allowing their water heaters to be turned off during periods of peak electrical demand. The ability to control these water heaters results in lower costs for consumer. Large water heaters (55+ gallon capacity) offer an effective way to utilize excess off peak energy, including available renewable energy, and to avoid adding to peak electrical demand.

Jackson Electric Cooperative ${ }^{1}$ is one of the leading utilities deploying water heating DR. The technology requires installation of a Load Control Receiver. This receiver allows their wholesale power supplier (Dairyland Power cooperative) to be able to control water heaters during peak hours. Households who participate in this program receive a $\$ 3$ water heater credit applied to their monthly electric bill. Given the absence of economical ways to store electrical energy, storing thermal energy is an effective storage solution currently available.

Hot water storage may be integrated into a hybrid water heater with DR capability. One manufacturer ${ }^{2}$ claims that by using the heat pump (only) in the heat pump water heater to keep the water heated, as well as using DR capability, the appliance has the capacity to save $1,856 \mathrm{kWh} / \mathrm{yr}$.

\subsubsection{Hybrid On-Site Generation Systems}

Hybrid on-site generation systems are documented within (Ruangpattana, 2011), (Higbee, 2005), (Facchinetti, 2011), and (Wilson, 2010). Ruangpattan and Higbee detail hybrid wind and PV systems and Facchinetti and Wilson give information a hybrid microturbine and fuel cell system. The basic strategy of these systems is to maximize the power generation while reducing costs and minimize times of low power generation.

Cost data were not found on residential scale hybrid on-site generation systems. In (Ruangpattana, Klabjan, Arinez, \& Biller, 2011), the authors develop a model to make selection and sizing decisions to maximize revenue from on-site generation systems for industrial sites. In a case study, their model selected each one of the wind and solar options. The $7,154 \mathrm{~kW}$ solar project on a $500,000 \mathrm{ft}^{2}$ roof surface area resulting in $495 \mathrm{ft}^{2}$ of solar panel area with an installation cost of $\$ 60$ million is selected. For wind, the model selects a $6,031 \mathrm{~kW}$ wind farm of 200 turbines costing $\$ 251$ million to install. This results in a negative net present value suggesting that owning an on-site renewable energy generation is not yet financially viable in this case study even with state investment incentives and federal production tax credit benefits.

\footnotetext{
${ }^{1}$ http://docs.jackelec.com/programs/Water\%20Heater\%20Brochure.pdf

${ }^{2}$ G.E. (2012) "G.E. Appliances"

http://products.geappliances.com/ApplProducts/Dispatcher?REQUEST=SpecPage\&Sku=GEH50DNSRSA
} 


\subsubsection{Cost Analysis for On-Site Generation in Single-Family Residences}

An estimation of on-site generation costs is presented and documented in Table 1.3-1. For the purpose of calculation, we use the specific costs of one particular capacity of the on-site generator as documented in the table. In Figure 1.3-1, average annual energy expenditures for single-family residences for selected states are shown. These data can be used for comparison with the cost of on-site generation systems.

It can be concluded that economically, the installed price for the available distributed generation and renewable energy system is still very high, leading to a $\$ / \mathrm{kWh}$ cost that is significantly higher than electricity purchased from a utility (almost by a factor 2-3 or higher) (Higbee, Brehm, Sen, \& Ammerrnan, 2005), and therefore cannot be justified at the present time for only energy needs. However, with the increased cost of energy coupled with the advent of power electronics and research and development efforts for renewable energy applications, it is a realistic goal that the future power supply for residential customers will include a percentage of on-site generation systems.

Table 1.3-2 categorizes the cost of operation and installation of hybrid systems and their potential power generation. The costs within this table are taken from the research papers. Within the $\$ / \mathrm{kW}$ calculations, the total power is the sum of the estimated generation of the hybrid system.

\subsubsection{Integration of On-Site Generation Technologies and Home Energy Management}

Along with the on-site generation technology research, general research papers applicable to residential on-site generation were also found. Specific papers of interest within this workbook are (O'Neil, 2011), (Zeifman, 2011), and (Heo, 2008). Each of these details a differing way of controlling appliances within the smart home setting. These papers give information on HEM and load monitoring for on-site generation systems. The basic HEM system discussed within these papers is a simple LED screen that details that total power used by a certain appliance.

In addition, commercial products are available that perform integration of multiple power sources as examined in the project. One such system ${ }^{1}$ has two inputs each for AC and DC power, each DC terminal can connect to 10-50 volts sources like batteries, solar panels, fuel cells, DC wind generators, alternators, etc. The AC connections are for AC loads, the grid and generators. The power modules are $2 \mathrm{~kW}$ and as many as 12 can be connected together for up to $24 \mathrm{~kW}$. The manufacturer states that this system can function as any combination of inverter, grid-tie inverter, UPS, charge controller, DC-DC converter, programmable power supply or load bank, etc.

\footnotetext{
${ }^{1}$ HT2000 Power Module from Heart Transverter, Costa Rica, http://www.transverter.com/
} 
Table 1.3-1. Estimation of cost for installing and operating residential on-site generation systems.

\begin{tabular}{|c|c|c|c|c|}
\hline $\begin{array}{c}\text { On-Site } \\
\text { Generator }\end{array}$ & $\begin{array}{c}\text { Capacity } \\
\text { kW }\end{array}$ & $\begin{array}{c}\text { First Cost } \\
\$ / \mathbf{k W}\end{array}$ & $\begin{array}{c}\text { Installation Cost } \\
\$ / \mathbf{k W} \\
\end{array}$ & $\begin{array}{c}\text { Operation Cost / } \\
\text { Maintenance Cost } \\
\$ / \mathbf{k W} \\
\end{array}$ \\
\hline $\begin{array}{l}\text { Internal } \\
\text { combustion } \\
\text { engine }\end{array}$ & $5-10$ & $450-550^{(a)}$ & $\begin{array}{l}400-800 \text { for } \\
\text { transfer switch } \\
\text { hardware }^{(\mathrm{b})}\end{array}$ & $5-6$ per hour at rated load ${ }^{(\mathrm{c})}$ \\
\hline Fuel cell & 5 & $15,000^{(\mathrm{d})}$ for one $5 \mathrm{~kW}$ unit & NA & 51,000 (over 10 years) $^{(\mathrm{e})}$ \\
\hline PV & 10 & $5,000^{(\mathrm{f})}$ & $4,000^{(\mathrm{g})}$ & $0^{(\mathrm{h})}$ \\
\hline Wind turbine & $\begin{array}{l}10 \text { producing } \\
\text { between } 10,000 \text { to } \\
18,000 \mathrm{kWh} \text { per } \\
\text { year }^{(\mathrm{k})}\end{array}$ & $3,000-8,000^{(i)}$ & $25,000-35,000^{(\mathrm{j})}$ & $\begin{array}{l}0.03-0.06^{(\mathrm{j})} \\
20-25 \% \text { of the total cost per } \\
\mathrm{kWh} \text { produced over the lifetime } \\
\text { of the turbine. }{ }^{(\mathrm{k})}\end{array}$ \\
\hline $\begin{array}{l}\text { Energy } \\
\text { Storage }\end{array}$ & $\begin{array}{c}\text { Capacity } \\
\text { kW }\end{array}$ & $\begin{array}{c}\text { First Cost } \\
\$ / \mathbf{k W}\end{array}$ & $\begin{array}{c}\text { Installation Cost } \\
\$\end{array}$ & $\begin{array}{c}\text { Operation Cost / } \\
\text { Maintenance Cost } \\
\text { \$/kW }\end{array}$ \\
\hline $\begin{array}{l}\text { Electric water } \\
\text { heaters }\end{array}$ & 4 & $\begin{array}{l}125, \text { assuming } \$ 500 \text { as the cost } \\
\text { for a new electric resistance } \\
\text { water heater) to retrofit } \\
\text { existing water heaters to be } \\
\text { DR-enabled. } \\
150-200, \text { assuming } \$ 600 \text { - } \\
\$ 800 \text { for new electric } \\
\text { resistance water heater with } \\
\text { DR-enabled retrofit } \\
250 \text { - } 375 \text {, assuming } \$ 1,000 \text { - } \\
\$ 1,500 \text { for new DR-enabled } \\
\text { hybrid (heat pump) water } \\
\text { heater }{ }^{(1)}\end{array}$ & $\begin{array}{l}600-800 \text { for electric } \\
\text { resistance water }^{(m)} \\
\text { heater }^{(m)} \\
2000-3000 \text { for } \\
\text { hybrid water }_{\text {heater }^{(\mathrm{n})}}\end{array}$ & NA \\
\hline Batteries & Variable & $\begin{array}{l}80-200^{(0)} \text { based on battery } \\
\text { technology }\end{array}$ & NA & NA \\
\hline $\begin{array}{ll}\text { (a) } & \text { Retrieved } f \\
\text { (b) } & \text { Retrieved } \mathrm{f} \\
& \underline{1 \& \text { storeId= }} \\
\text { (c) } & \text { See http://b } \\
\text { (d) } & \text { http://www } \\
\text { (e) } & \text { (Total first } \\
\text { (f) } & \text { Retrieved } \mathrm{f} \\
\text { (g) } & \text { Retrieved } \mathrm{f} \\
\text { (h) } & \text { Retrieved } \mathrm{f} \\
\text { (i) } & \text { Retrieved } \mathrm{f} \\
\text { (j) } & \text { Retrieved } \mathrm{f} \\
\text { (k) } & \text { Retrieved } \mathrm{f} \\
& \text { power/oper } \\
\text { (l) } & \text { Retrieved } \mathrm{f} \\
& \text { carry-out cc } \\
\text { (m) } & \text { Based on a } \\
& \text { http://www } \\
\text { (n) } 2001 \text { Water } \\
& 16,2012 . \mathrm{It} \\
\text { (o) } & \text { Retrieved } \mathrm{f}\end{array}$ & 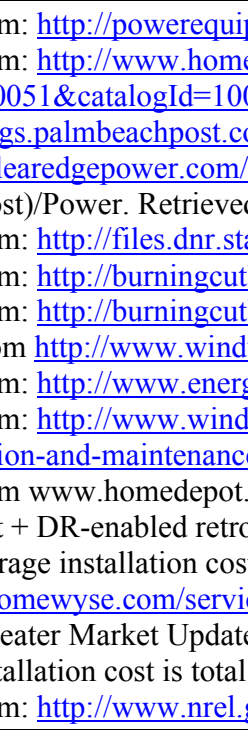 & $\begin{array}{l}\text { ent.honda.com/generators/genera } \\
\text { pot.com/h d1/N-5yc1vZbm1f/h } \\
\text { /eyeonthestorm/before-the-storm } \\
\text { l-cell/fuel-cell-efficiency } \\
\text { com: http://www1.eere.energy.go } \\
\text { mn.us/aboutdnr/energysmart/sol } \\
\text { y.com/solar/ } \\
\text { y.com/solar/ } \\
\text { ry.org/resources/how-much-do-y } \\
\text { ca.gov/distgen/equipment/wind/c } \\
\text { lergy-the-facts.org/en/part-3-ecol } \\
\text { osts-of-wind-generated-power.ht } \\
\mathrm{m} \text { and www.lowes.com Septemb } \\
\\
\text { MN from: } \\
\text { /cost to install electric water } \\
\text { repared by Verinnovation, Inc. f } \\
\text { stalled cost in Table } 4.15 \text { minus } \mathrm{t} \\
\text { /docs/fy02osti/31689.pdf retriev }\end{array}$ & $\begin{array}{l}\text { tor-power-manageme } \\
\text { d2/Navigation?langId } \\
\text { /generator-maintenanc } \\
\text { v/femp/pdfs/fuelcell t } \\
\text { ar_payback_calculator } \\
\text { vind-turbines-cost } \\
\text { ost.html } \\
\text { momics-of-wind-power } \\
\text { el } 20,2012 \text {. Cost for e } \\
\text { er } 2012 \text {. } \\
\text { or the Nortwest Energ } \\
\text { he first cost. } \\
\text { ed May } 31,2012 \text {. }\end{array}$ & $\begin{array}{l}\text { r.pdf } \\
\text { e-be-prepared-before-a-storm } \\
\text { chapter-1-cost-of-on-land-wind- } \\
\text { lectric resistance water heater is } \\
\text { Efficiency Alliance, January }\end{array}$ \\
\hline
\end{tabular}




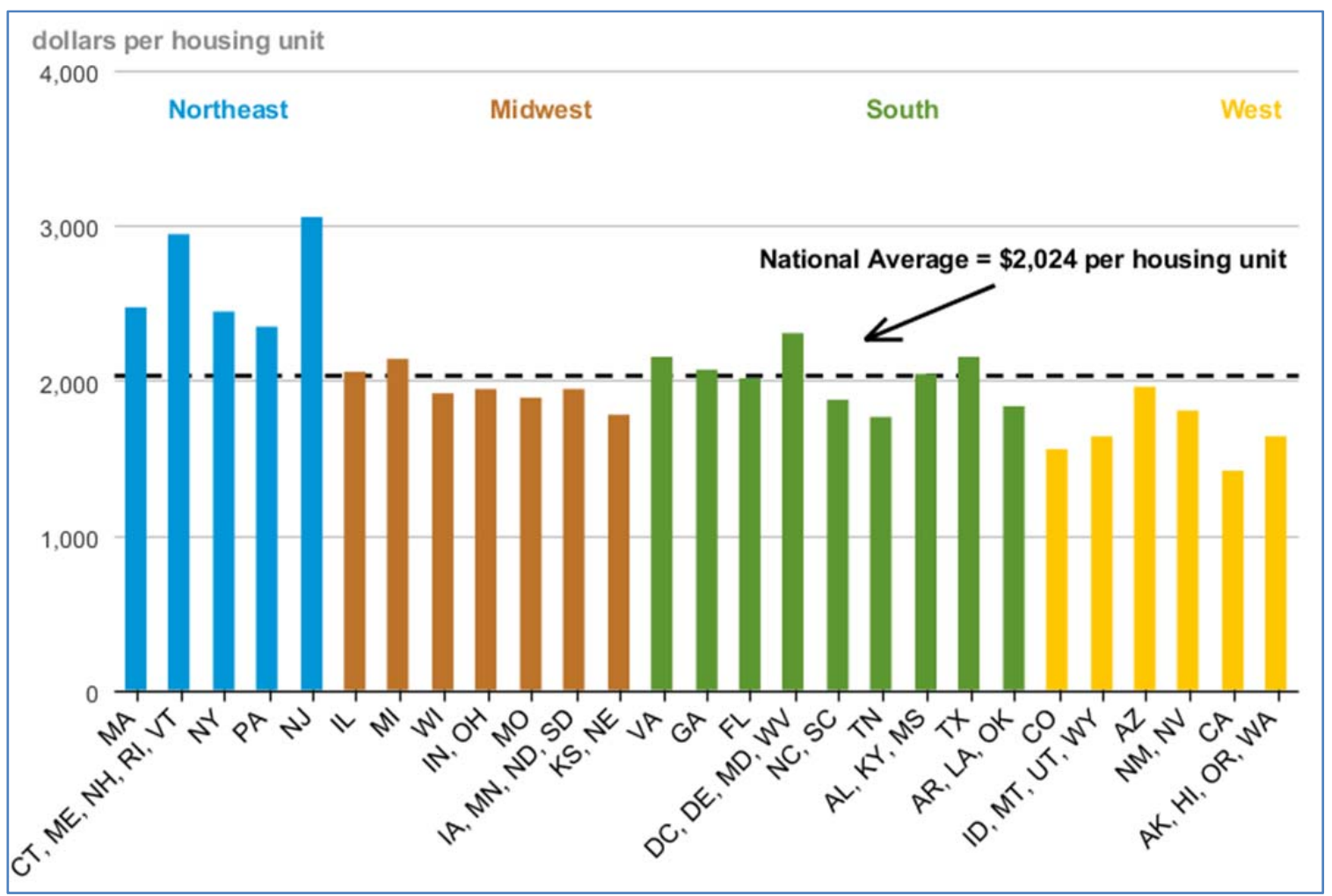

Figure 1.3-1. Average home energy expenditures for selected states, 2009. Source: EIA Residential Energy Consumption Survey

Table 1.3-2. Estimated cost for hybrid on-site generation systems.

\begin{tabular}{|l|l|}
\hline Hybrid On-site Generator Technology & \multicolumn{1}{c|}{ Estimated Costs } \\
\hline PV and wind turbine & Estimated installation cost \\
& PV: $\$ 60$ million for $7,154 \mathrm{~kW}$ capacity \\
& Wind turbine: $\$ 250$ million for $6,031 \mathrm{~kW}$ capacity \\
& Total $=\$ 2,351 / \mathrm{kW}$ \\
& Source: (Ruangpattana, Klabjan, Arinez, \& Biller, 2011) \\
\hline Fuel cell and microturbine & Estimated installation cost \\
hybrid system & Capstone C200 Microturbine: \$320,000 for 200kW capacity \\
& Solid oxide fuel cell module: \$2,000 for 5kW \\
& Total $=\$ 1,570 / \mathrm{kW}$ \\
& Source: (Wilson, 2010) TO BE UPDATED \\
\hline
\end{tabular}

\subsubsection{State and Federal Incentives for Residential On-Site Generation Technologies}

On-site generation technologies are often subsidized by the state and federal government. This literature review includes the collection of information on the availability of state and federal incentives for differing on-site generation technologies. There are different types of financial incentives and regulatory policies that are available in order to stimulate utilization of renewable energy in the U.S. 
Database of State Incentives for Renewables \& Efficiency (DSIRE ${ }^{1}$ ) has color-coded summary maps that provide geographical overview of different incentives. These include, but not limited to, grant programs, loan programs, property tax incentives, rebate programs, sales tax incentives, and tax credits. Examples of these maps are shown in Figure 1.3-2 to Figure 1.3-5.

Although, these maps do not indicate type of on-site generators these incentives are available for, they still provide a good overview of different funds available in each state. Further information can be extracted from DSIRE especially for states and regions in the U.S. that have maximum potential for appliance replacement. Details of incentives available in Minnesota, where CASHEM demonstration homes are located are given in Table $1.3-3^{2}$.

Figure 1.3-2 shows grant programs in different states. As the map color-coded key indicates, orange colored states have state program(s) only, yellow represents states with utility, local, or private program(s) only, and red indicates state program(s) plus utility, local, or private program(s). Figure 1.3-3 shows tax credits for renewables. Personal tax credit(s), corporate tax credit(s), and personal plus corporate tax credit(s) are shaded in orange, yellow and red respectively. Figure 1.3-4 shows rebate programs for renewables in the U.S. In this map, colors orange, yellow and red represent states that have state program(s) only, utility, local and/or non-profit program(s) only, and state program(s) plus utility, local and/or non-profit program(s). Finally, Figure 1.3-5 shows sales tax incentives that are available across the nation. Red represents state tax exemption or deduction and red represents states with state exemption plus local governments that are authorized to offer exemption or deduction.

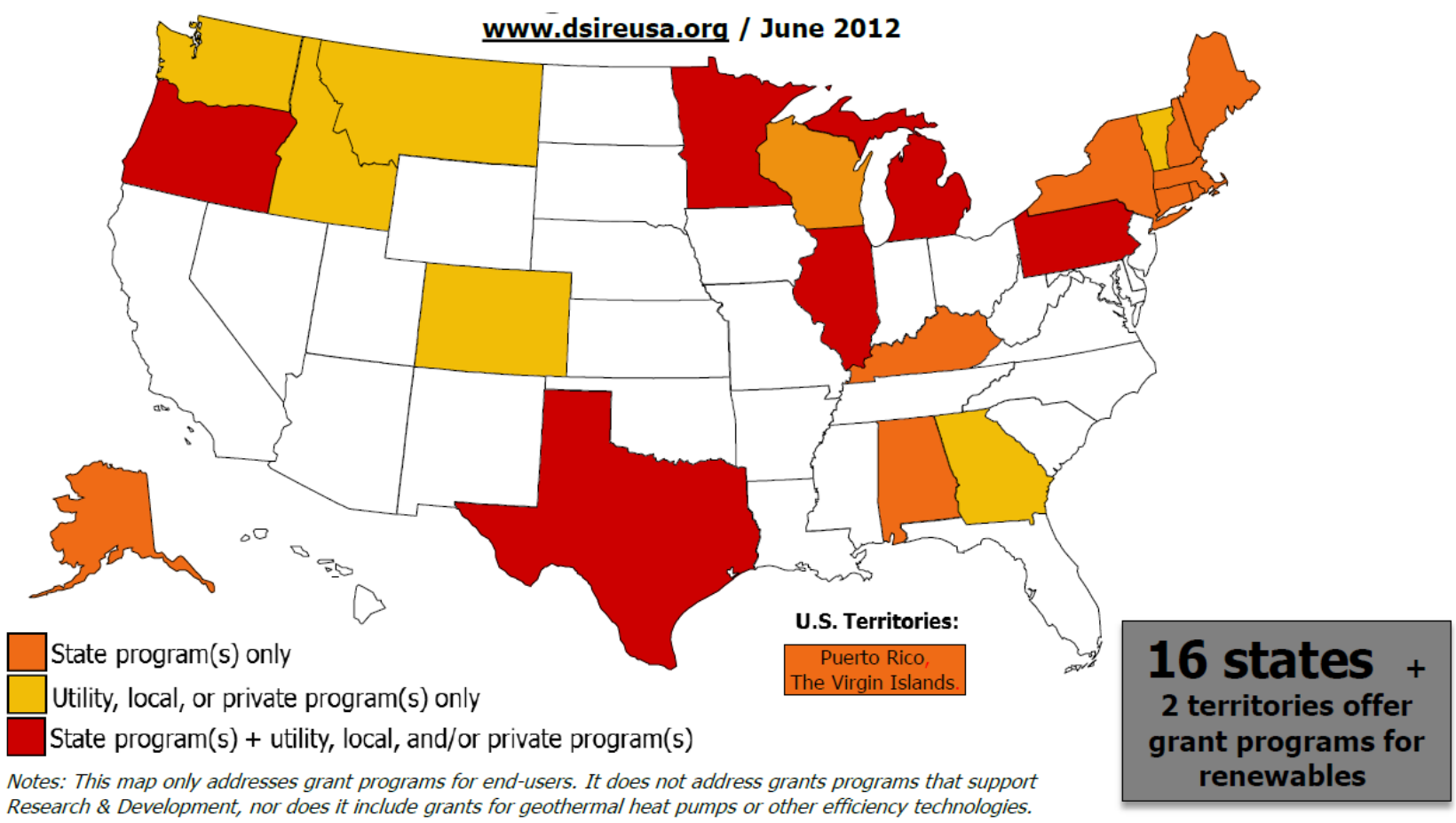

Figure 1.3-2. Grant programs for renewables. Source: http://www.dsireusa.org/documents/summarymaps/Grants Map.pdf

\footnotetext{
1 http://www.dsireusa.org/

2 Local tax incentives given in this table are for the city of Minneapolis or Anoka.
} 


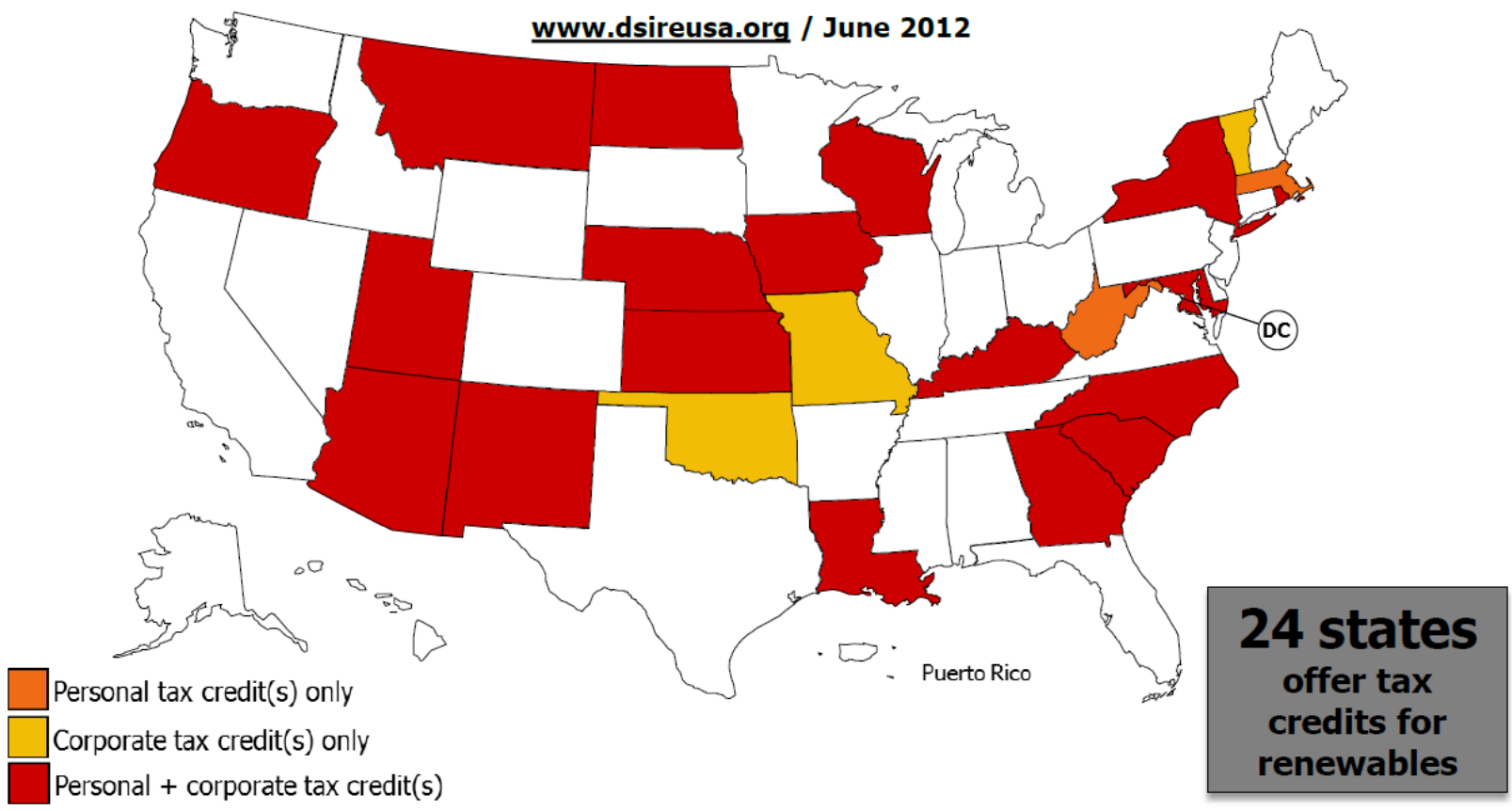

Notes: This map does not include corporate or personal tax deductions or exemptions; or tax incentives for geothermal heat pumps.

Figure 1.3-3. Tax credits for renewables. Source:

http://www.dsireusa.org/documents/summarymaps/TaxCredits_Map.pdf

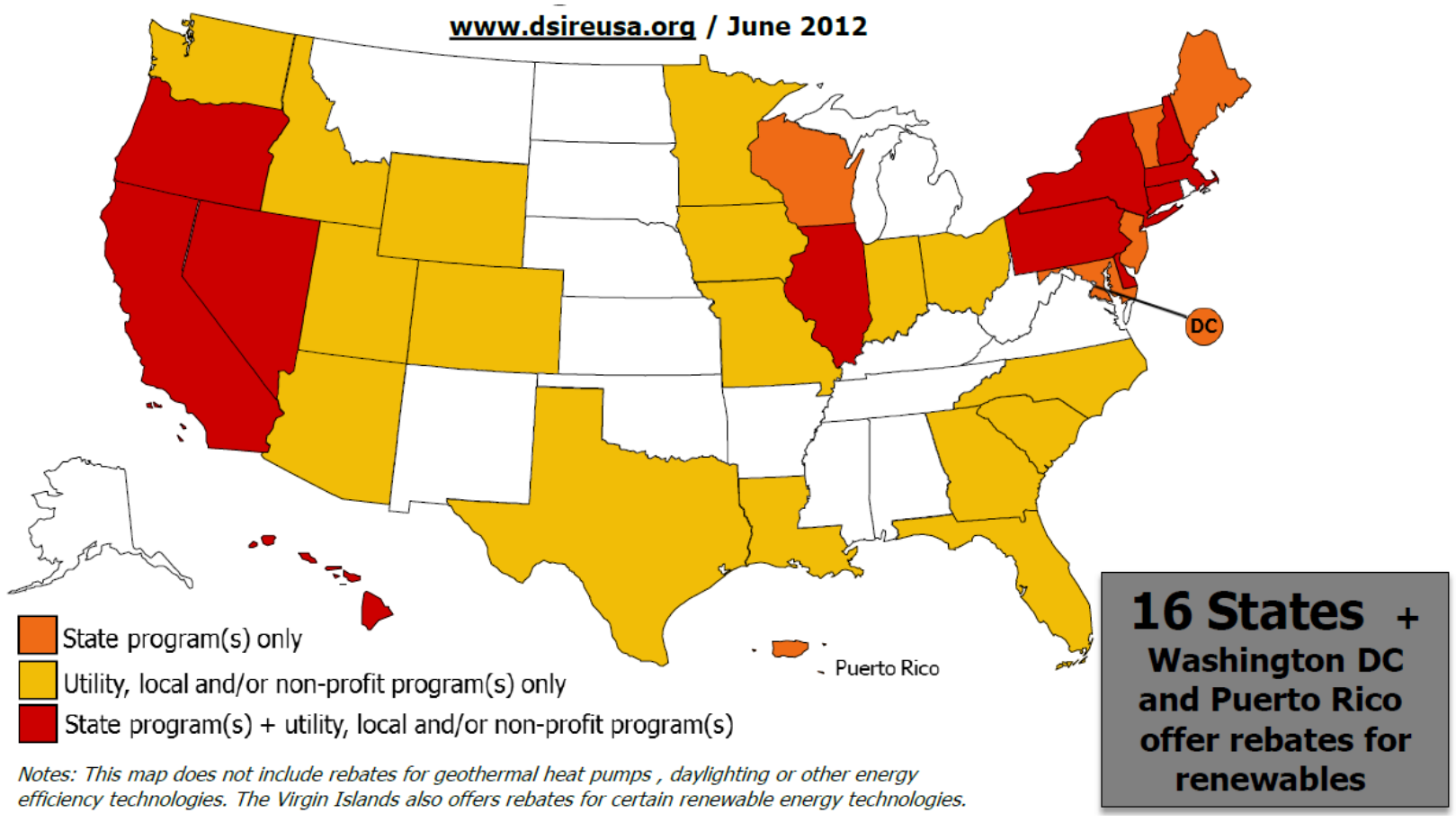

Figure 1.3-4. Rebate programs for renewables in different states. Source:

http://www.dsireusa.org/documents/summarymaps/Rebate map.pdf 


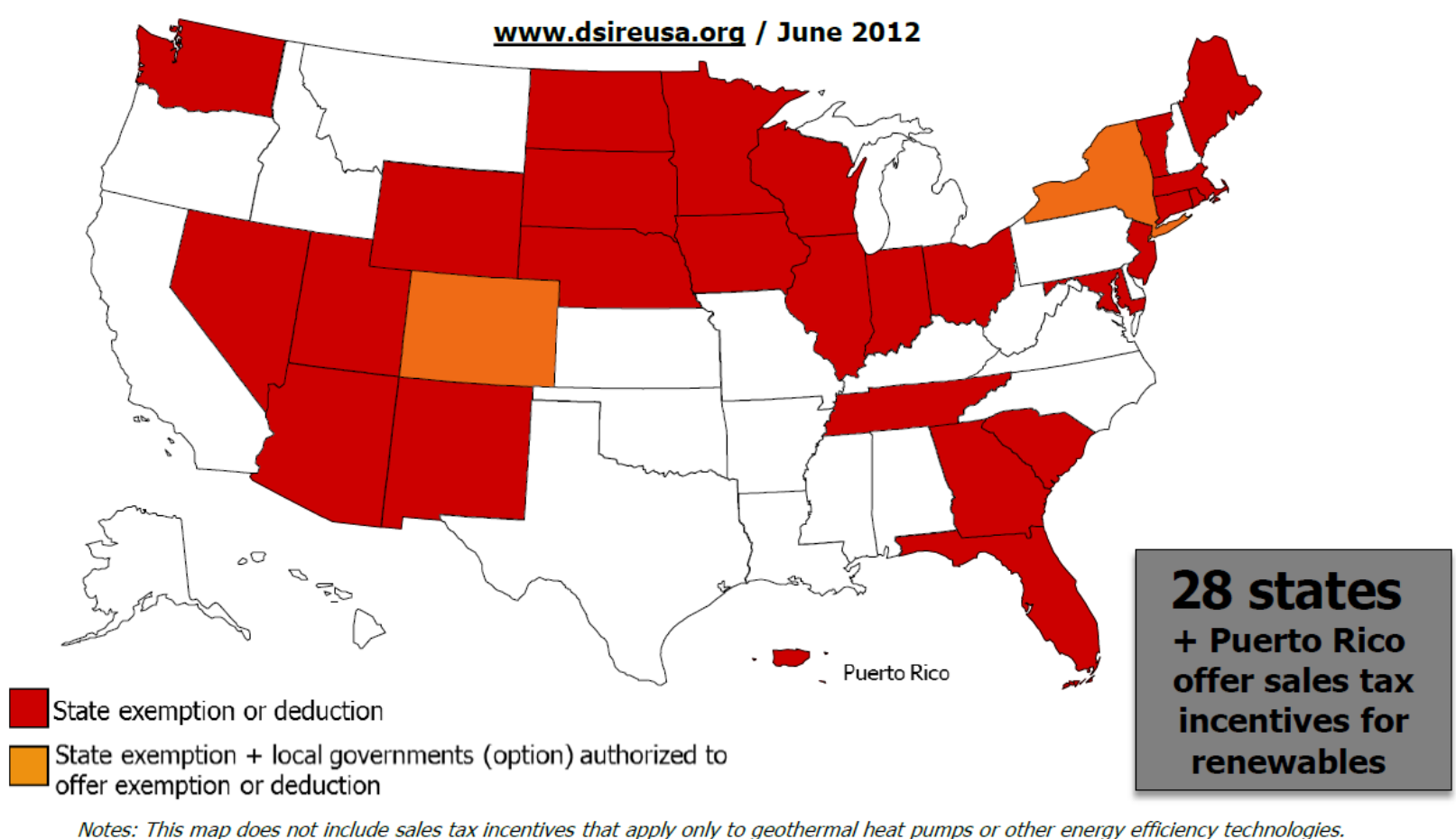

Figure 1.3-5. Sales tax incentives for renewables in different states. Source: http://www.dsireusa.org/documents/summarymaps/SalesTax map.pdf

Table 1.3-3. Summary of on-site generation incentives available in Minnesota. Source: Database of State Incentives for Renewables \& Efficiency (DSIRE), http://www.dsireusa.org

\begin{tabular}{|l|l|l|}
\hline $\begin{array}{c}\text { On-site } \\
\text { Generation } \\
\text { Technology }\end{array}$ & \multicolumn{1}{|c|}{$\begin{array}{c}\text { Exemptions and } \\
\text { Incentives }\end{array}$} & \multicolumn{1}{c|}{ Tax Credits } \\
\hline $\begin{array}{l}\text { Internal } \\
\text { combustion } \\
\text { engine }\end{array}$ & NA & NA \\
\hline Fuel cell & $\begin{array}{l}\text { Renewable Development } \\
\text { Fund - amount varies } \\
\text { based on size }\end{array}$ & $\begin{array}{l}\text { Personal Tax Credit: } 30 \% \\
\text { Maximum incentive available: } \$ 500 \text { per } 0.5 \mathrm{~kW}\end{array}$ \\
\hline PV & $\begin{array}{l}\text { Solar Energy Sales Tax } \\
\text { Exemption: } 100 \% \\
\text { Exemption }\end{array}$ & $\begin{array}{l}\text { Personal Tax Credit: } 30 \% \\
\text { Solar-electric systems placed in service before } 1 / 1 / 2009: \$ 2,000 \\
\text { Solar-electric systems placed in service after } 12 / 31 / 2008: \text { no maximum }\end{array}$ \\
\hline Wind turbine & $\begin{array}{l}\text { Wind Energy Sales Tax } \\
\text { and Property Tax } \\
\text { Exemption: 100\% } \\
\text { Exemption }\end{array}$ & $\begin{array}{l}\text { Personal Tax Credit: } 30 \% \\
\text { Wind turbines placed in service in 2008: } \$ 4,000 \\
\text { Wind turbines placed in service before 1/1/2009: no maximum }\end{array}$ \\
\hline NA=no information available. & \\
\hline
\end{tabular}


Figure 1.3-6 shows direct cash incentives available for solar projects in different U.S. states. There are 22 states plus District of Columbia (DC), Puerto Rico (PR), and the U.S. Virgin Islands (USVI) that offer direct cash incentives for solar projects. According to DSIRESOLAR, direct cash incentives for solar are "a variety of forms, including rebates, buydowns, grants, and performance-based incentives. A rebate is an incentive payment issued to a purchaser after the system has been installed, while buydown refers to reductions in the bottom-line cost to purchasers. Grants generally involve more detailed, competitive applications for larger projects. "' More than 20 states and 200 utilities offer direct incentives for PV and/or solar thermal systems. These incentives typically cover $20 \%$ to $50 \%$ of project costs and range from a few hundred dollars to millions of dollars.

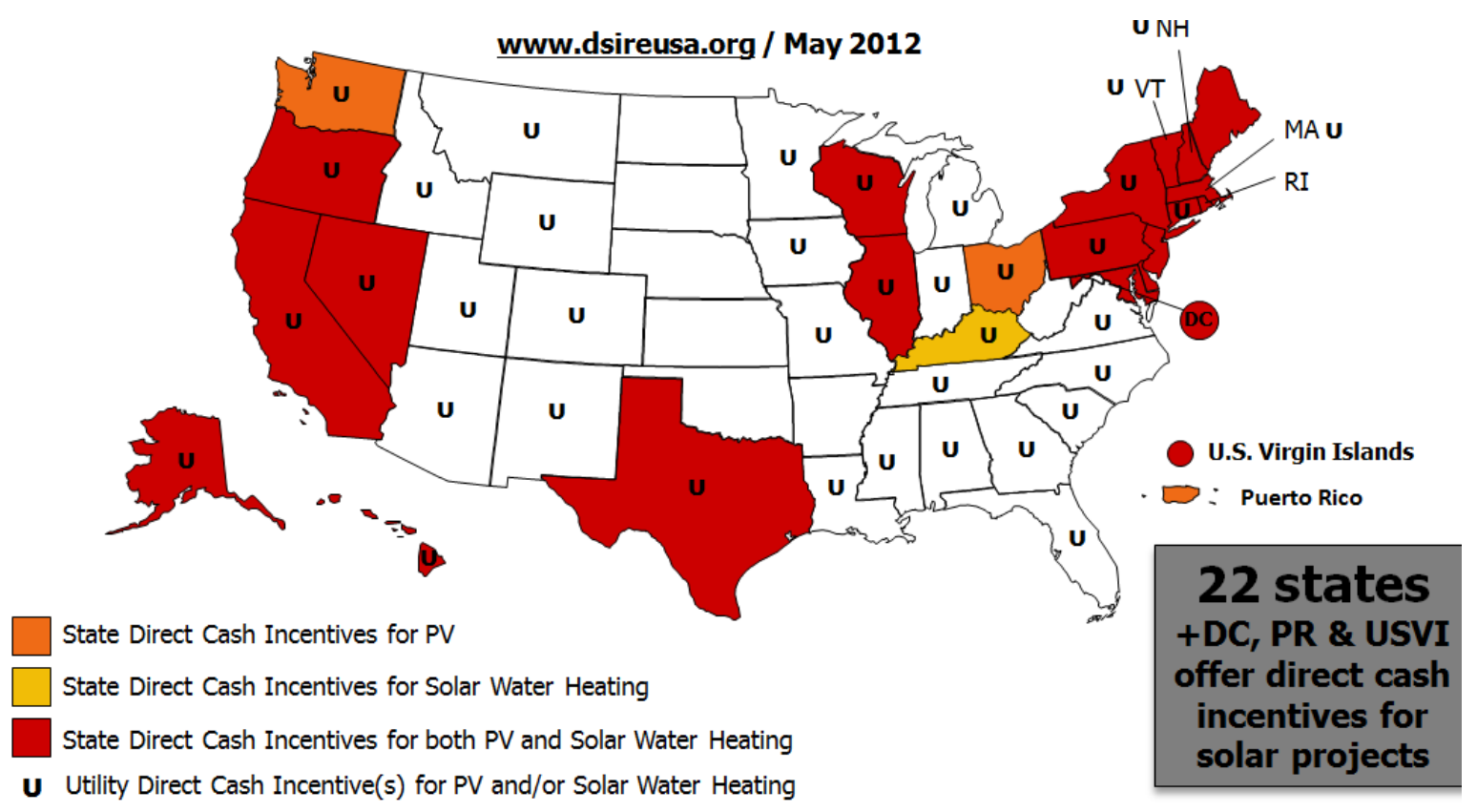

Figure 1.3-6. Direct cash incentives available for solar projects.

Source: http://www.dsireusa.org/solar/solarpolicyguide/?id=10

Table 1.3-3 shows a summary of incentives available in the state of Minnesota for different on-site generation systems. It should be noted that Minnesota is among states that have energy efficiency resource standards that include both electricity and natural gas savings requirements. Details of the energy efficiency resource standard are: $1.5 \%$ reduction of previous 3-year average retail electric sales by 2010; $1.5 \%$ reduction of previous 3 -year average retail natural gas sales by $2010 .^{2}$ This policy is designed to encourage installation of on-site generators that use renewable energy and non-natural gas on-site generators.

\subsubsection{Conclusions}

In performing this literature review, we focused on characterization of on-site generation sources applicable to single-family residences. In Table $1.3-4$, the estimated $\$ / \mathrm{kW}$ cost and attributes of the onsite generation technology are summarized. The attributes focus on beneficial aspects of the systems. The

\footnotetext{
${ }^{1} \mathrm{http://www.dsireusa.org/solar/solarpolicyguide/?id=10}$

2 http://www.dsireusa.org/documents/summarymaps/EERS_map.pdf
} 
assignment of the attributes was based on information collected from the research papers. This is not a complete or comprehensive list of all on-site generation technologies, but an overview of the most integrated and commonly reported systems. The $\$ / \mathrm{kW}$ is an estimation of the total capital per $\mathrm{kW}$. This estimate only includes the total capital cost and not the operation and maintenance or cost of installation. This information is based on manufactures information found during the literature search.

Table 1.3-4. Ranking of on-site generation technologies based on the $\$ / \mathrm{kW}$ and attributes documented in literature

\begin{tabular}{|c|c|c|c|}
\hline Rank & $\begin{array}{c}\text { On-site Generator } \\
\text { Technology }\end{array}$ & Estimated First $\$ / \mathbf{k} \mathbf{W}^{\mathbf{1}}$ & Attributes \\
\hline 1 & $\begin{array}{l}\text { Internal combustion } \\
\text { engine }\end{array}$ & 450 to 550 & $\begin{array}{l}\text { Readily dispatched } \\
\text { UPS capability } \\
\text { Response time ( } \mathrm{sec}) \\
\text { Low total capital costs } \\
\text { Ease of integration into grid }\end{array}$ \\
\hline 2 & Fuel cell & 15,000 & $\begin{array}{l}\text { Readily dispatched } \\
\text { UPS capability } \\
\text { Response time (sec) } \\
\text { Low total capital cost } \\
\text { Incentives available }\end{array}$ \\
\hline 3 & Roof-top solar PV arrays & 5,000 & $\begin{array}{l}\text { Readily dispatched } \\
\text { Incentives available }\end{array}$ \\
\hline 4 & Wind Turbine & NA & Incentives available \\
\hline Rank & $\begin{array}{l}\text { On-site Storage } \\
\text { Technology }\end{array}$ & Estimated \$/kW & Attributes \\
\hline 1 & Electric water heater & $\begin{array}{l}125 \text { (Add mixing valves }+ \text { transactive control } \\
\text { to an existing } 4 \mathrm{~kW} \text { water heater.) } \\
500 \text { (New DR- enabled } 4 \mathrm{~kW} \text { water heater.) }\end{array}$ & $\begin{array}{l}\text { Readily dispatched } \\
\text { Low total capital cost } \\
\text { Ease of integration into grid } \\
\text { Response time (sec) }\end{array}$ \\
\hline 2 & Batteries & $80-200$ & $\begin{array}{l}\text { Readily dispatched } \\
\text { Low total capital cost } \\
\text { UPS capability } \\
\text { Response time (sec) } \\
\text { Ease of integration into grid }\end{array}$ \\
\hline
\end{tabular}

This information should be reviewed to further define and refine the scope of the research to understand with greater accuracy the initial capital costs, specific installation information as well as life cycle performance of the on-site generation technologies suitable for integration into a single-family residence. Further study is required in using the HEM to control a fast-ramping, high efficiency on-site generation system so as to respond rapidly to utility price signals and balancing market needs, and capture this financial value for both the utility and home owner. This will allow further study in on-site generation technologies that would be the most beneficial for CASHEM.

\footnotetext{
${ }^{1}$ Note: Estimated $\$ / \mathrm{kW}$ values shown are for an example product of each technology. Costs will vary for different products.
} 


\subsection{Define Residential Building Demographics and Characterize Homes and Appliance Use}

In this section, residential building demographics will be defined based on Residential Energy Consumption Survey (RECS) available for appliances installed in U.S. homes. These data are provided by the EIA. RECS (2009) residential building/appliances demographics include type of housing unit, housing ownership, year of home construction, number of household members, household income, census region and climate region.

\subsubsection{Background}

In section 1.2, a market size analysis was completed to estimate number of appliances that are ready for replacement based on their average life span. Based on this study, the number of appliances that have replacement potential in the near future was estimated. In addition the number of new units installed each year was estimated based on number of new homes constructed annually. These data were used to assess total market size for smart appliances and CASHEM. Results summarized in section 1.2 are shown in Figure 1.4-1.

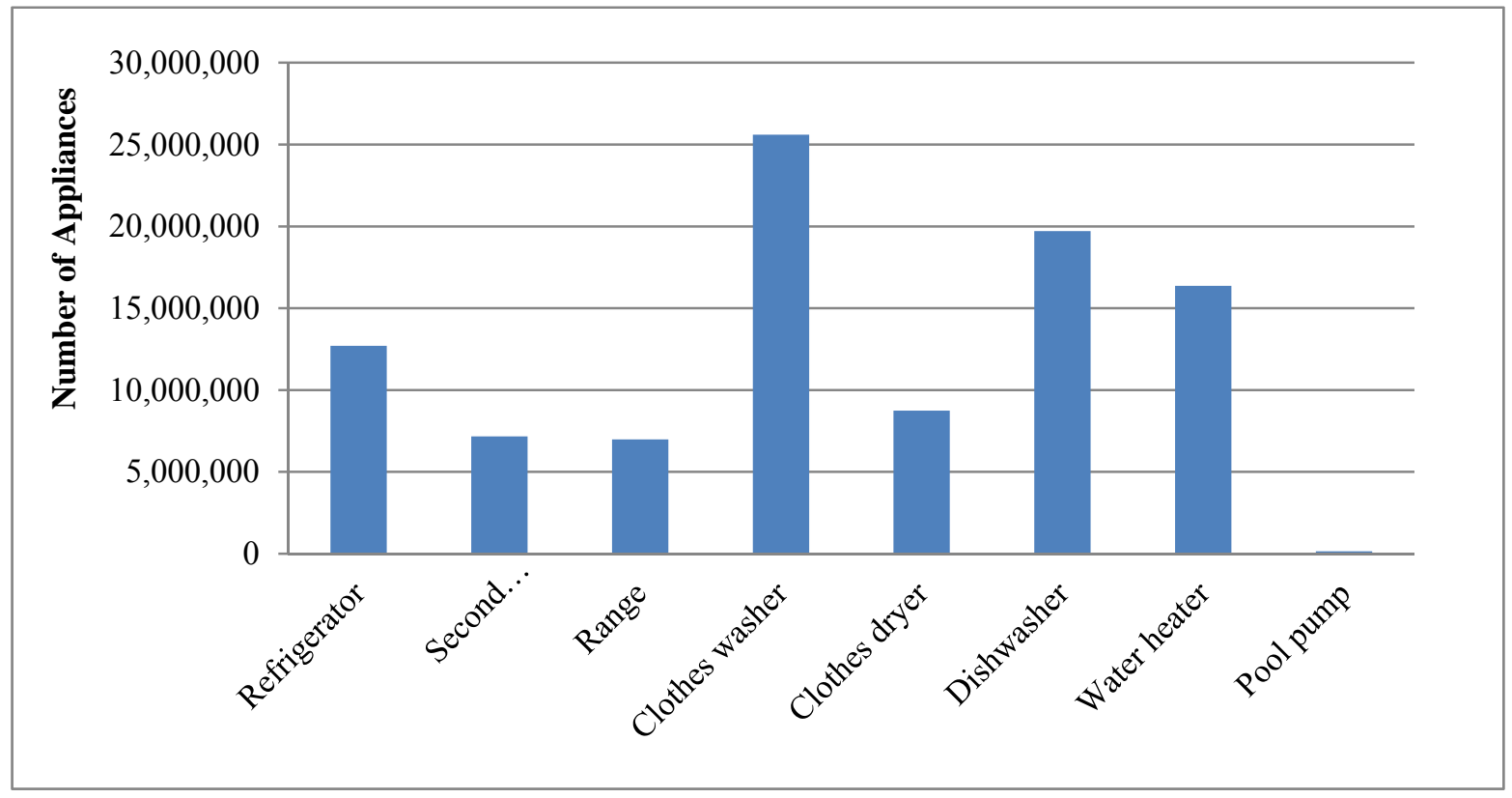

Figure 1.4-1. Total number of appliances that are ready for replacement in addition to estimate of annual new units installed.

\subsubsection{Appliances Demographics}

A further study has been done based on RECS (2009) to evaluate demographics of appliances and especially those that have replacement potential. This analysis will provide an estimation of the geographical concentration of appliances that have maximum replacement potential in order to determine market for appliances and CASHEM. 
Figure 1.4-2 shows the growth trend in number of appliances in the U.S. based on year of construction of homes until year 2009. These data can be used to predict and estimate growth rate of appliances in the next decade.

Figure 1.4-3 through Figure 1.4-5 show the trend in total number of appliances in the U.S. based on demographics from RECS (2009) ${ }^{1}$.

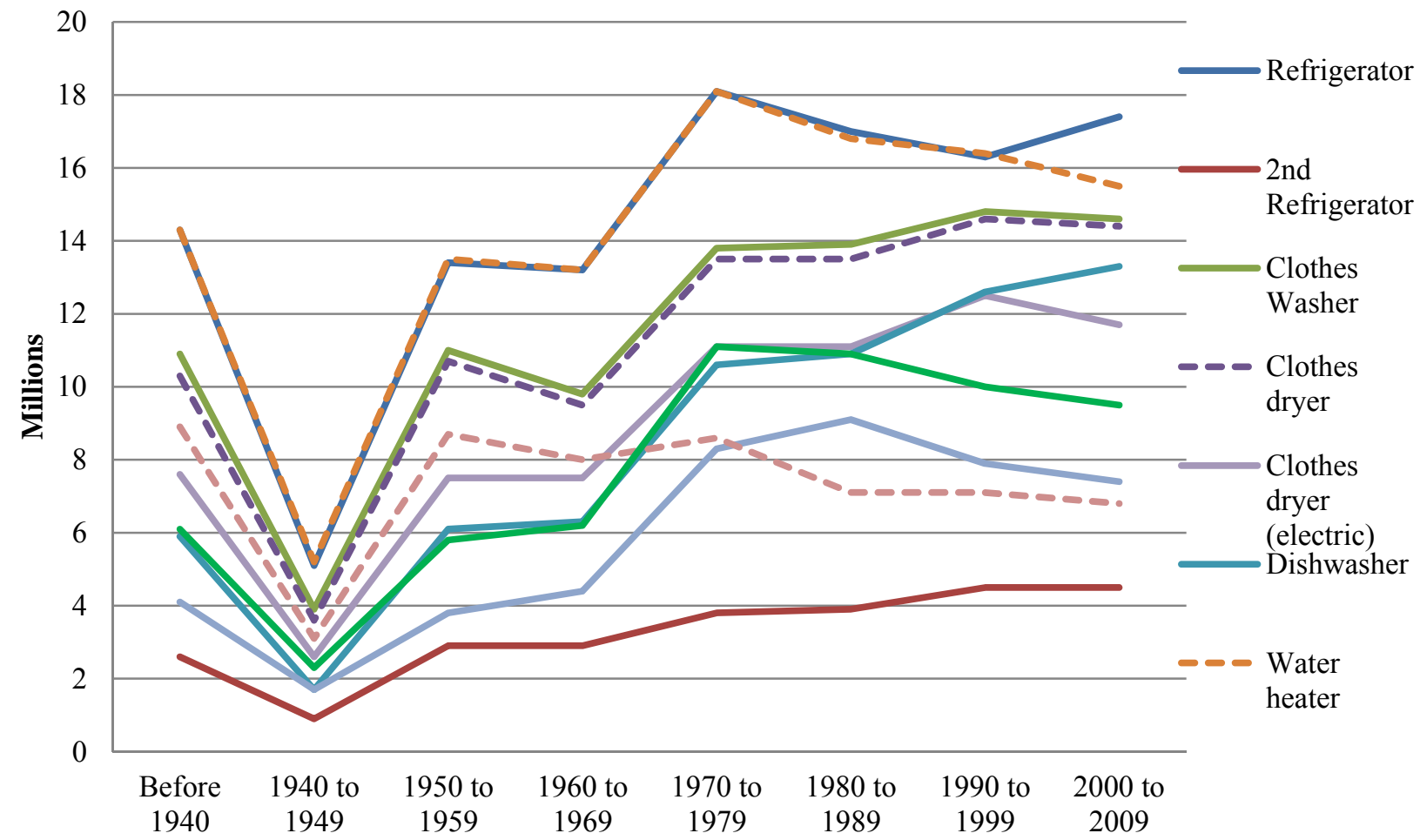

Figure 1.4-2. Change in total number of appliances in the U.S. based on year of construction of homes.

\footnotetext{
${ }^{1}$ Note that RECS data do not show water heaters by income level and thus water heaters are not included in these tables.
} 


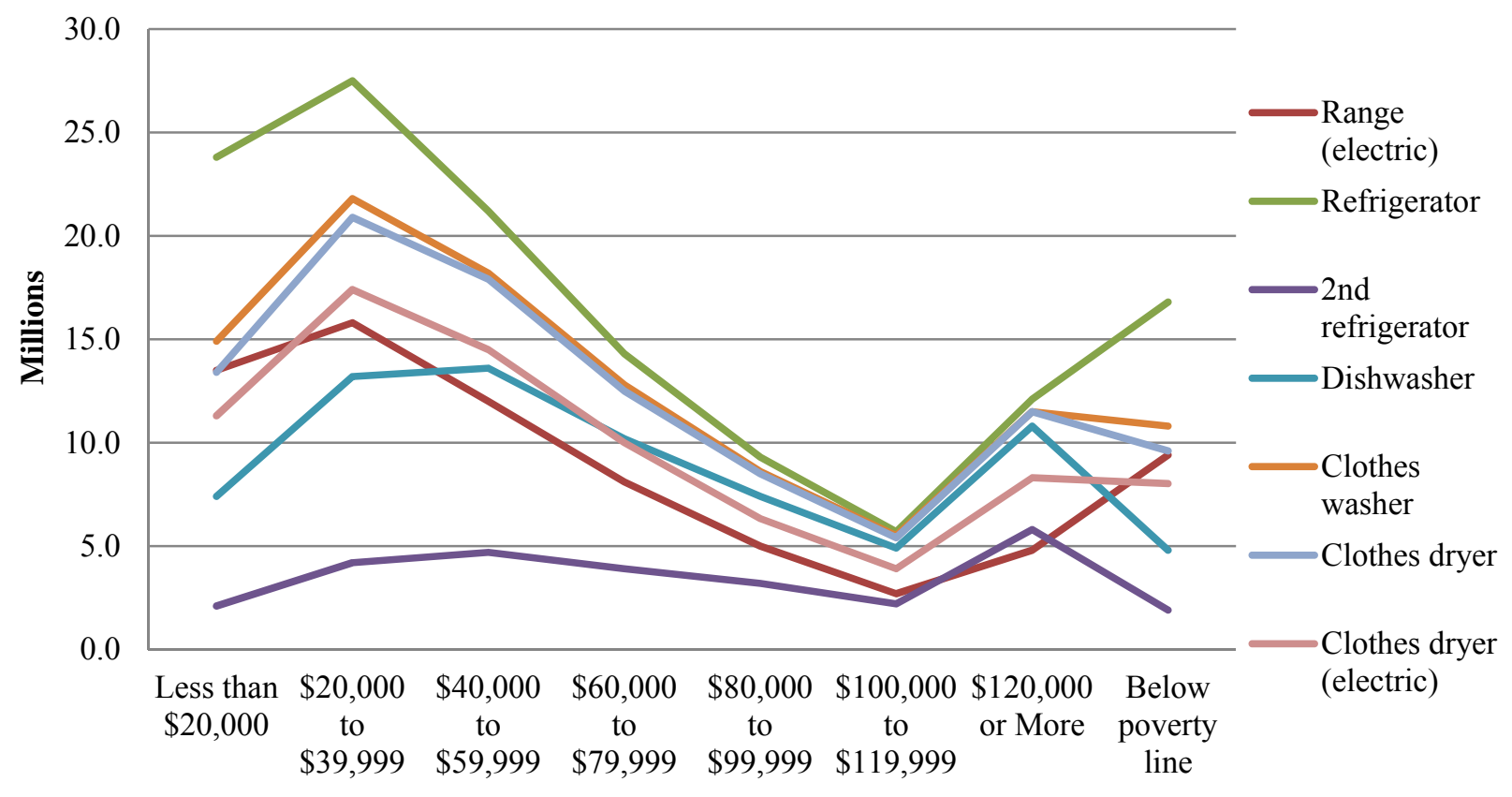

Figure 1.4-3. Change in total number of appliances based on household income.

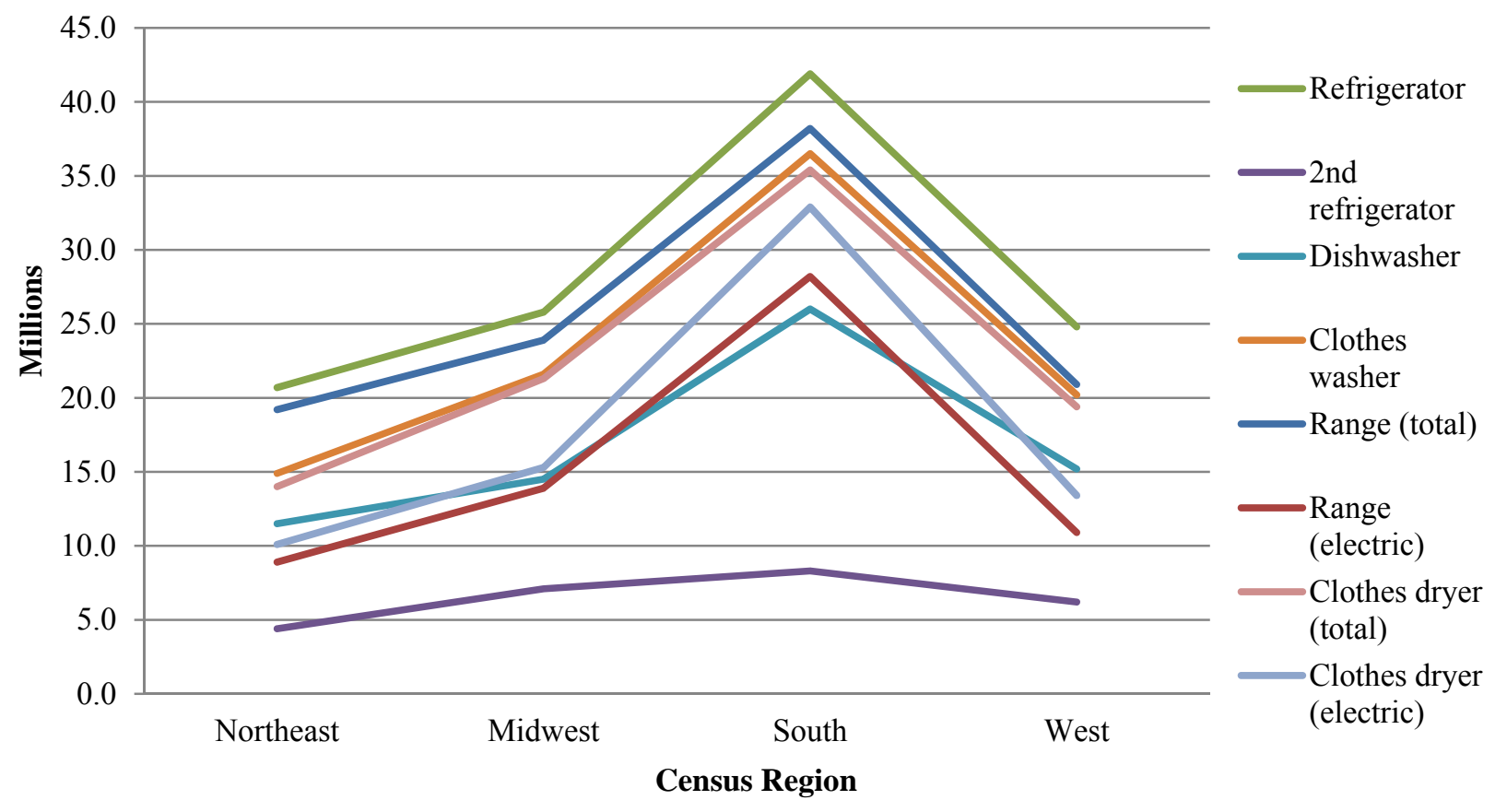

Figure 1.4-4. Trend in total number of appliances based on the U.S. census regions. 


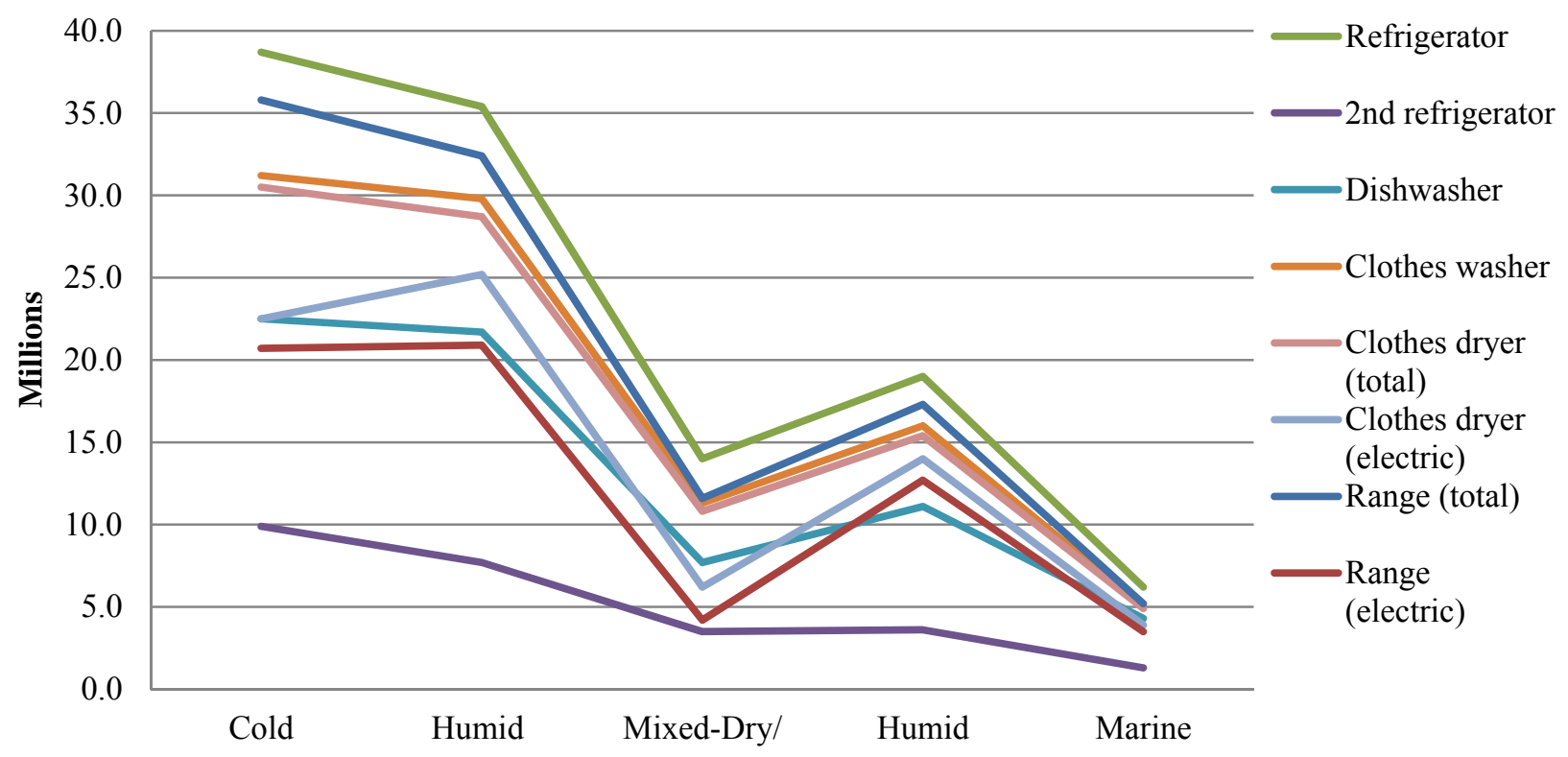

Figure 1.4-5. Trend in total number of appliances based on climate region.

\subsubsection{Compare/Contrast with CASHEM Demographics}

The assumed characteristics of CASHEM homes currently being used for experiments and data collection include:

- Single-family detached homes

- 2,000 to 3,000 square feet

- Located in the greater Minneapolis metro area (climate region 'cold', census region 'Midwest'2)

- have pool pumps

- have natural gas and gas heat

Based on RECS (2009):

- About $63 \%$ of total homes in the U.S are single-family detached homes

- Average size of single-family detached homes in the U.S. is around 2,486 square feet

- About 23\% of homes are located in census region 'Midwest' (Figure 1.4-6)

- More than $34 \%$ of homes are located in climate region 'cold/very cold' (Figure 1.4-7)

- More than $61 \%$ of total homes in the U.S. have natural gas

- About $49 \%$ of total homes use natural gas as their main space heating fuel

\footnotetext{
${ }^{1}$ See Figure 1.4-10 below for the climate regions in the U.S.

${ }^{2}$ See Figure 1.4-9 below for the census regions in the U.S.
} 


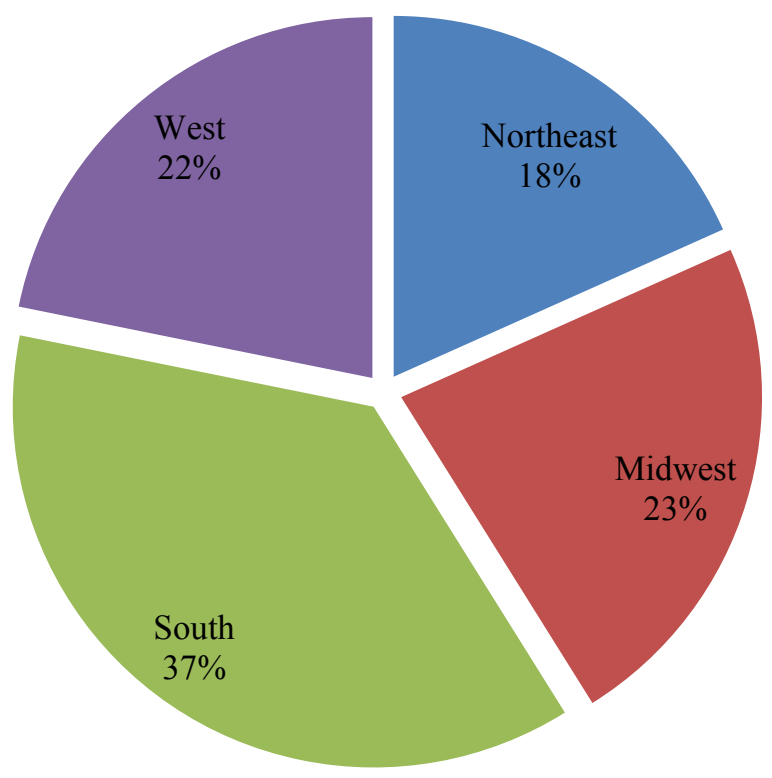

Figure 1.4-6. Distribution of housing units in different census regions.

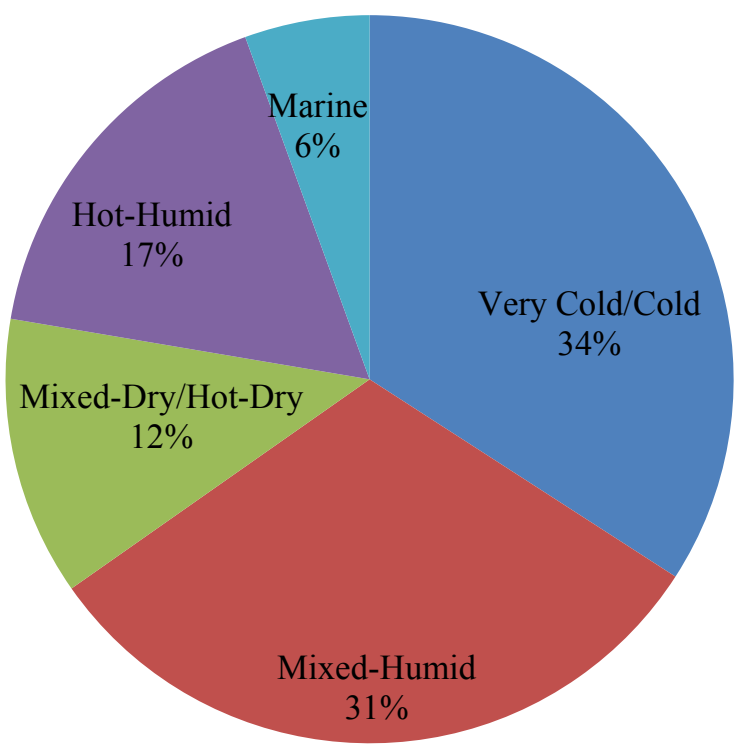

Figure 1.4-7. Distribution of housing units in different climate regions.

\subsubsection{Characterize the Market for the Down-Selected Appliance}

The purpose of this characterization is to identify the potential market for smart grid-enabled home appliances. Criteria considered for the market characterization include year of construction of homes, census region, climate region, and household income. 


\subsubsection{Replacement Potential Based on Year of Construction}

Figure 1.4-8 shows number of appliances that have replacement potential based on year of construction of homes until year 2009 (RECS, 2009). In Task 1.2, these appliances were characterized as those that are reaching their expected end of life according to the NAHB. In general, refrigerators, ranges, and clothes dryers have longer life expectancy compared to clothes washers, dishwashers, water heaters and pool pumps. According to data shown in Figure 1.4-8, most clothes washers with replacement potential are located in homes constructed from 1970 to 1979, most refrigerators and clothes dryers are in homes constructed from 1980 to 1989, and the rest (i.e., dishwashers and water heaters) are in houses constructed from 1990 to 1999. Although data for second refrigerators are shown, most probably residents will not consider replacing second refrigerators with smart grid-enabled units and will most likely replace the second refrigerator with the primary refrigerator when it is replaced (if still operating). However, those households with second refrigerators that are reaching the end of their life might consider replacing their first refrigerator with a smart grid-enabled unit.

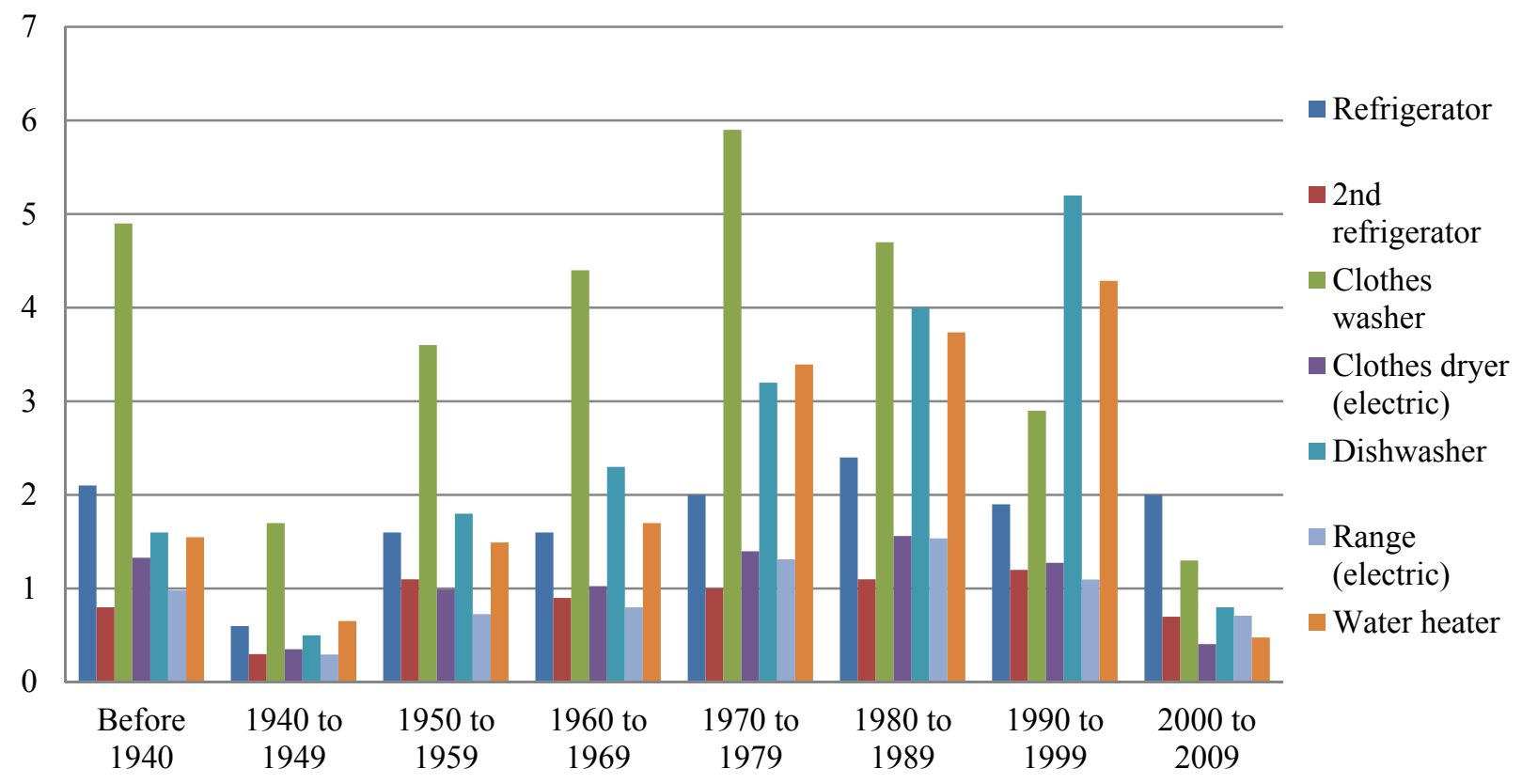

Figure 1.4-8. Distribution of units that have replacement potential in each decade.

\subsubsection{Replacement Potential Based on Census Region in the United States}

Figure 1.4-9 shows the number of appliances that have maximum replacement potential on the map of census regions and divisions of the United States prepared by the U.S. Census Bureau. RECS data presented on the map shows that most appliances that have replacement potential are concentrated in census region South followed by Midwest. RECS data do not show distribution of water heaters in different census regions and therefore water heaters are not shown in Figure 1.4-9. 


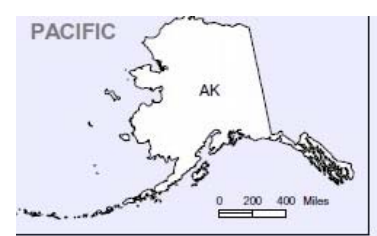

Concentration of units ready for replacement

in census regions of the United States

(numbers are in millions)

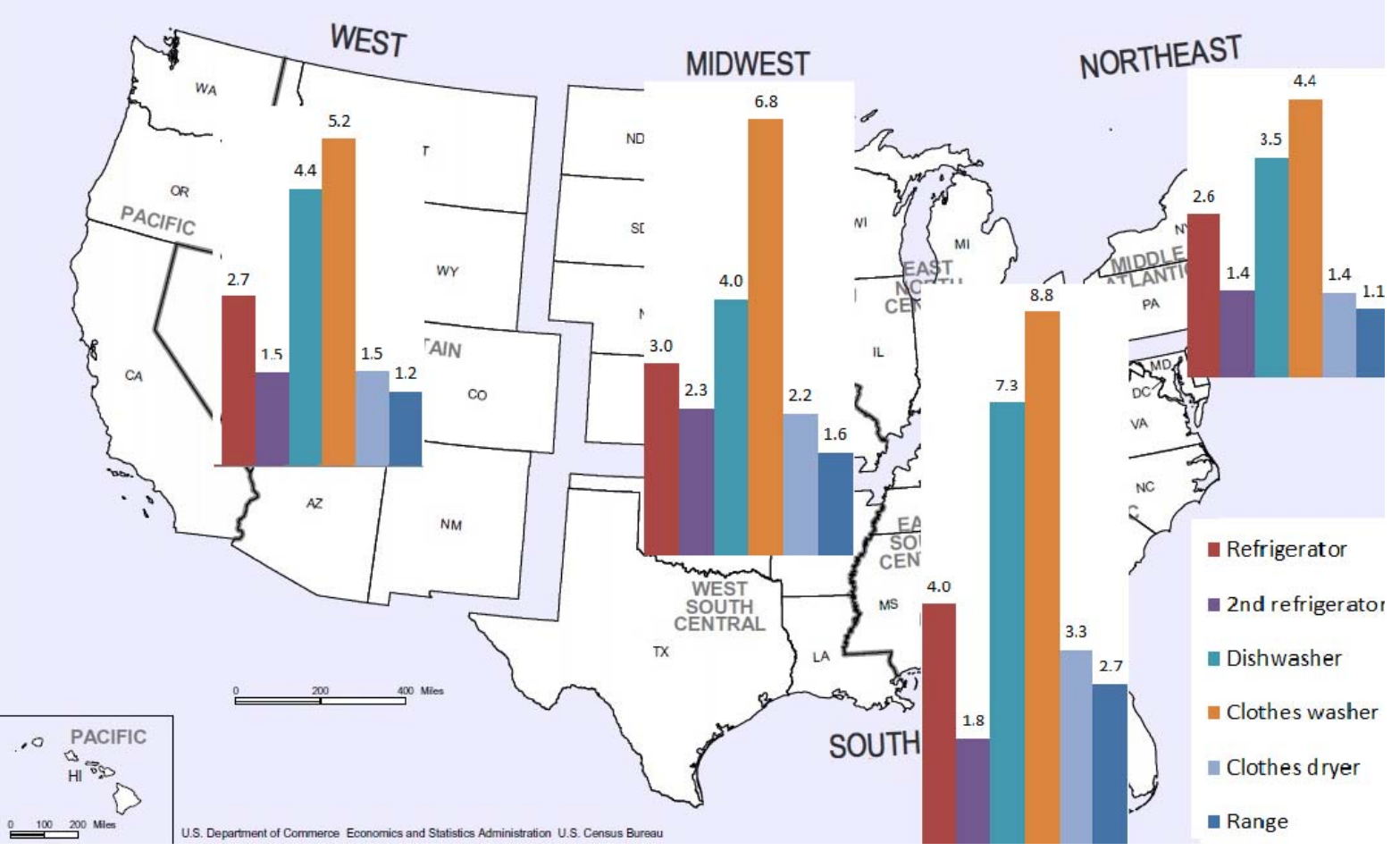

Figure 1.4-9. Distribution of units that have replacement potential in different census regions in the U.S.

\subsubsection{Replacement Potential Based on Climate Region in the United States}

RECS classification of climate zones is based on the climate descriptions used by the International Energy Conservation Code (IECC) and American Association of Heating, Refrigerating and AirConditioning (ASHRAE). The simplified version of climate zone map which is shown in Figure 1.4-10 was developed by PNNL and Oak Ridge National Laboratory (ORNL). This simplified map is combined of five categories: Cold/very cold, mixed-humid, hot-dry/mixed-dry, hot-humid, and marine (PNNL \& ORNL, 2010). 


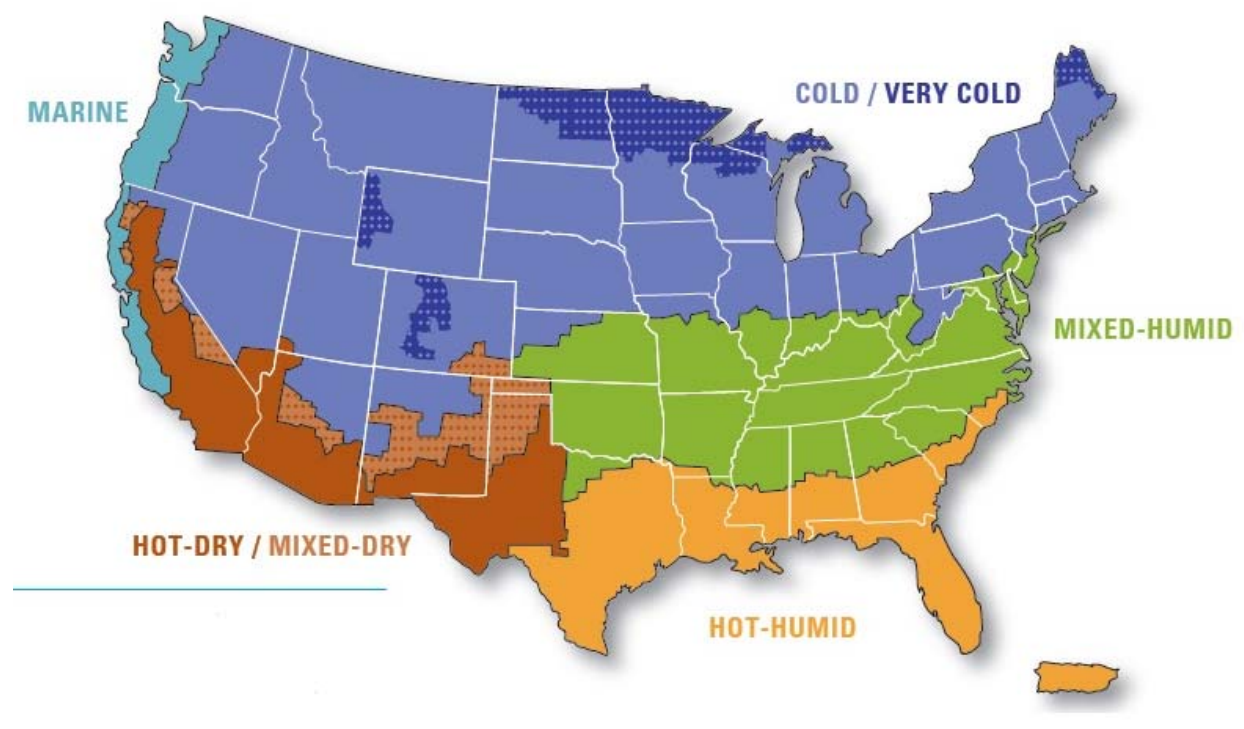

Figure 1.4-10. IECC simplified map of climate regions in the United States.

Figure 1.4-11 shows the concentration of appliances that have replacement potential in different climate regions in the U.S. Figure 1.4-11 shows that the greatest estimated number of replacement appliances are found in climate region cold/ very cold followed by mixed-humid region.

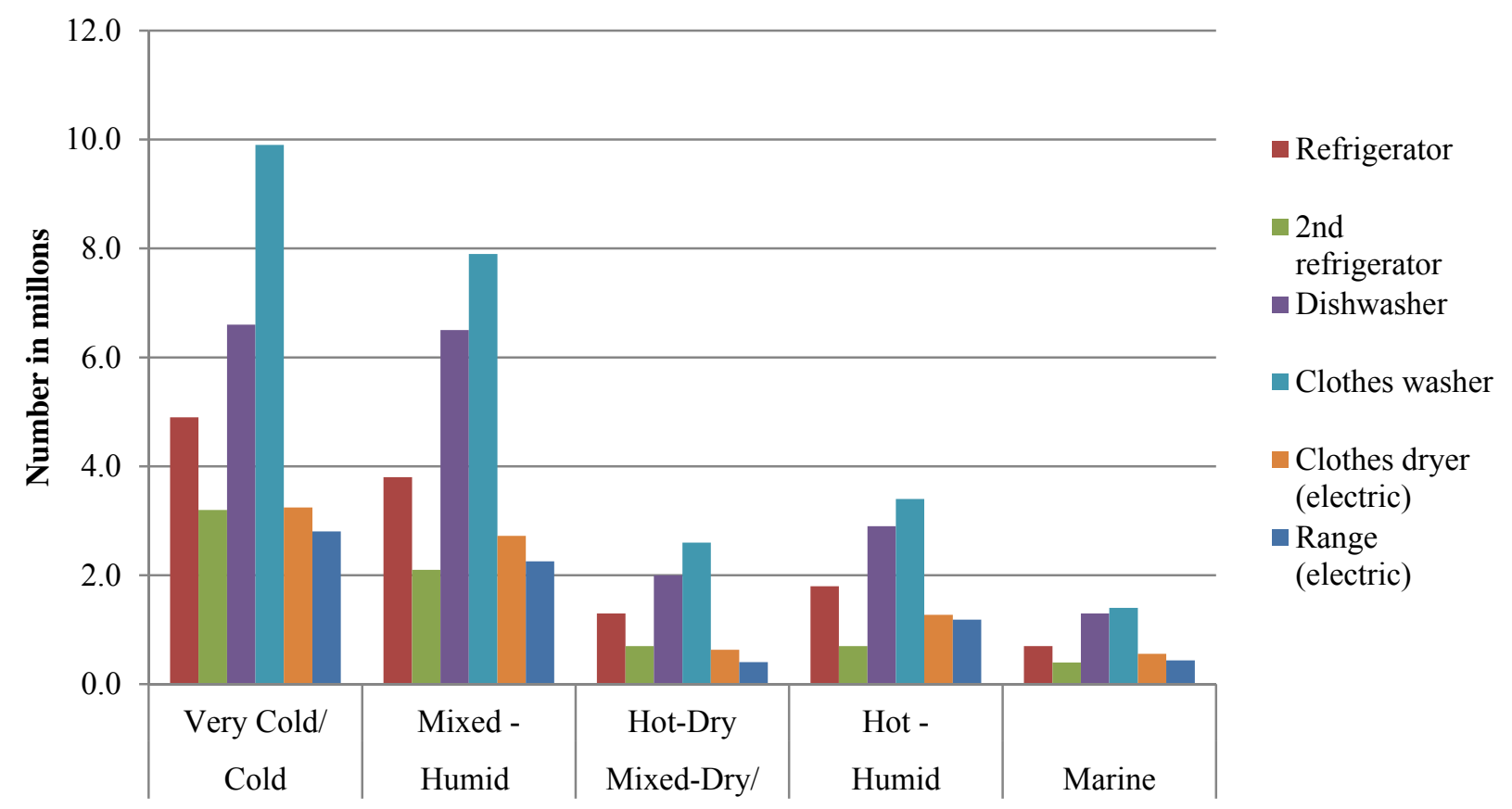

\section{Climate regions}

Figure 1.4-11. Distribution of units that have replacement potential in different climate regions in the U.S. 


\subsubsection{Replacement Potential Based on Household Income in the United States}

Figure 1.4-12 shows the concentration and distribution of appliances that have maximum replacement potential based on household income. Based on data shown, the majority of these appliances are found in households with annual household income from $\$ 20,000$ to $\$ 39,999$. There are studies that show higher income households are more likely to own household appliances ${ }^{1}$. Considering the cost of smart gridenabled appliances, households with higher income might have more resources to invest in such appliances. Further studies related to price elasticity of demand for smart grid-enabled appliances are needed to analyze potential market based on household income for CASHEM integrated appliances. Households with income higher than $\$ 100,000$ represent about $15 \%$ of population and based on data shown in Figure 1.4-13 they are located in census region South followed by West, Northeast, and Midwest.

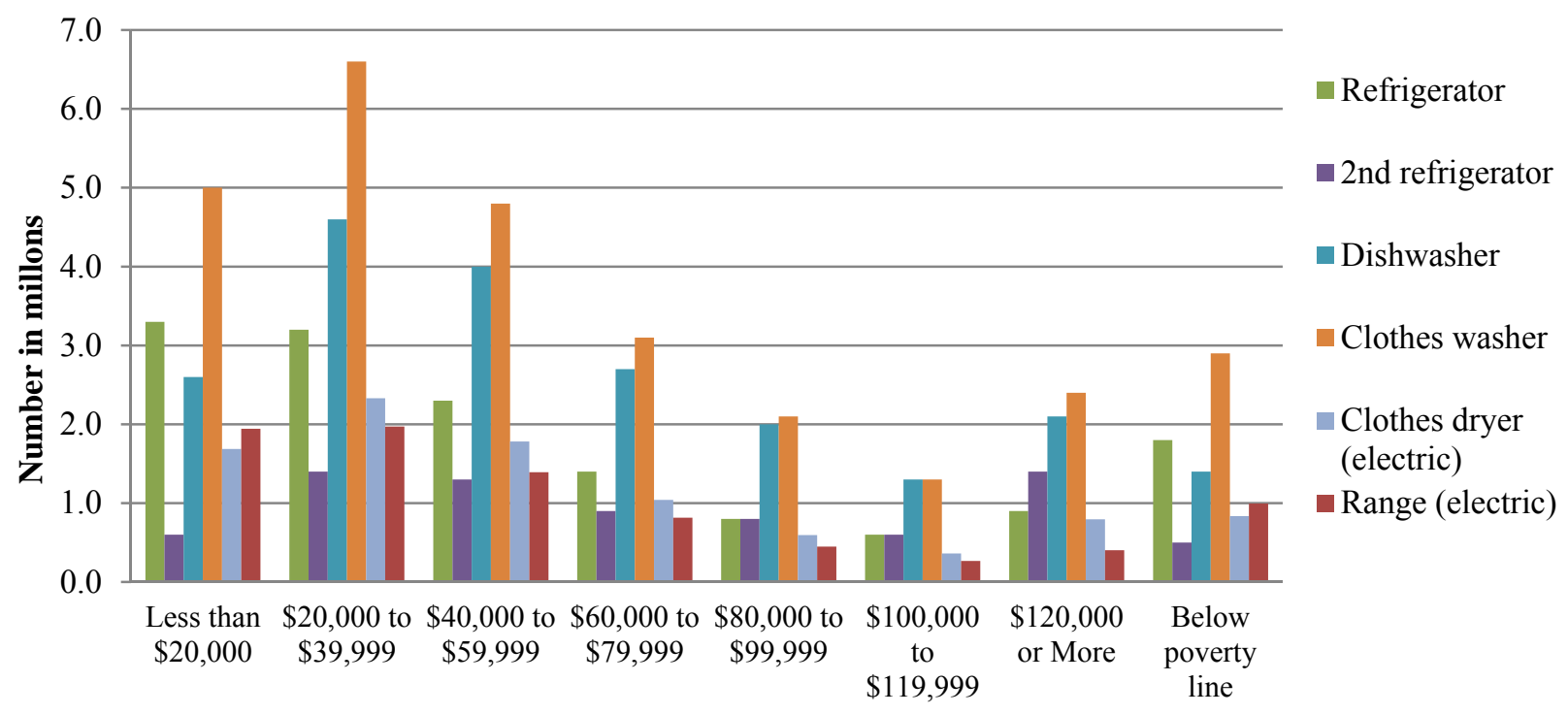

Household income

Figure 1.4-12. Distribution of units that have replacement potential based on household income.

\footnotetext{
${ }^{1}$ Energy Information Agency. "The Effect of Income on Appliances in U.S. Households.” U.S. Department of Energy:http://www.eia.doe.gov/emeu/recs/appliances/appliances.html. 2002. Accessed February 1, 2007.
} 


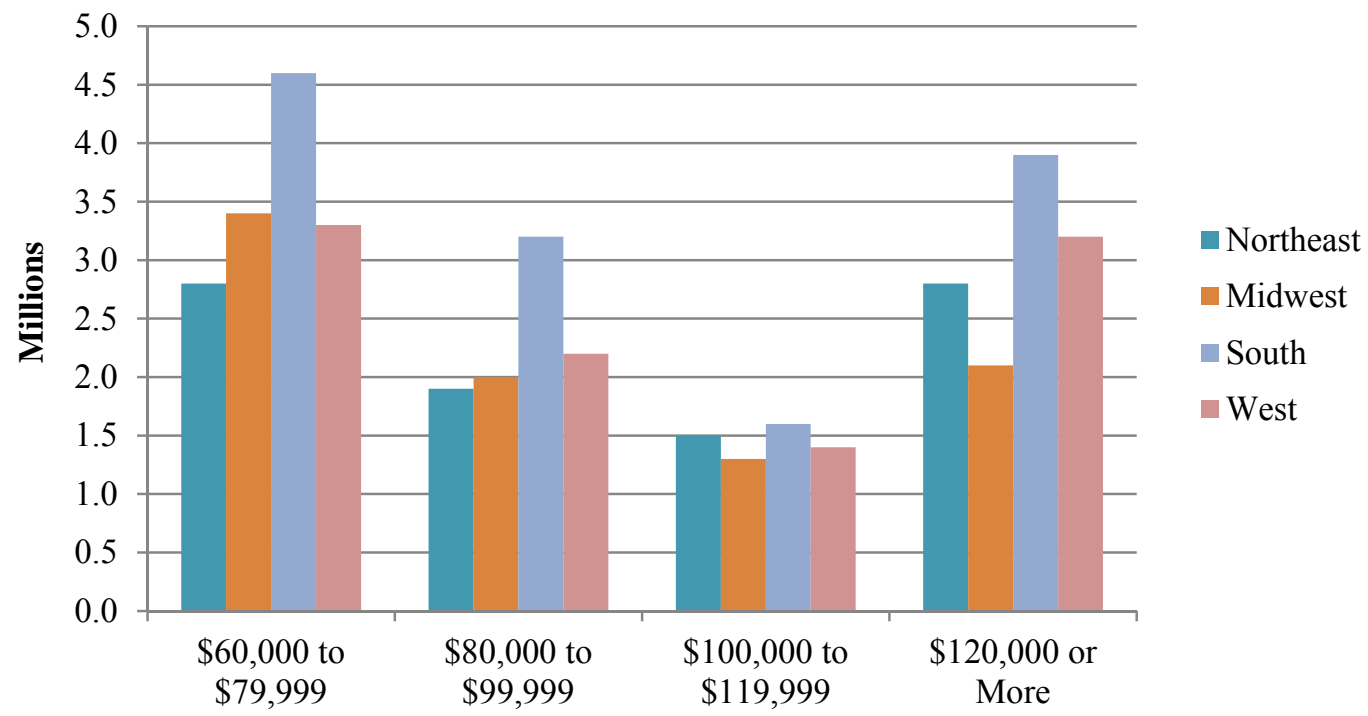

Figure 1.4-13. Income level in different census regions.

According to data included, most appliances that have replacement potential are located in climate regions mixed humid and cold/very cold as well as census regions South and Midwest. Because of the higher cost of smart appliance compared to conventional ones, it can be assumed that mostly people with more power to buy will invest in extra features of these appliances. RECS data summarized in Figure 1.4-13 shows number of people with higher income levels in different U.S. census regions. The location of potential market for smart appliances can therefore be approximated using information enclosed in this section. This includes states such as NY, MD, IL, north of GA, part of SC, and VA.

\subsubsection{Characterize the Market for the Down-Selected Generation Device}

In Task 1.3, on-site generator technologies down-selected include internal combustion engine, fuel cell, roof-top solar PV, and wind turbines. Energy storage systems included electric water heaters and batteries. These devices were selected and ranked based on different attributes such as estimated cost, availability, response time, UPS capability, and ease of integration.

In this section, the market for these down-selected devices will be characterized. This characterization will be based on availability of renewable energies in climate zones and census regions that were identified previously. This characterization will be based on publically-available data and EnergyPlus standardized residential models.

The market characterization for the down-selected on-site generators and storage devices will focus on climate zones 3, 4, and 5, and states included in this area, primarily Minnesota, where the CASHEM demonstration homes are located.

\subsubsection{Reference Home Models}

The DOE Building America (BA) program has developed residential building reference models mainly to be used for the purposes of energy reduction research and to perform cost and performance 
assessment. These models are used for different studies including integration of clean on-site power generator systems. Standard user profiles have also been developed to be used with these reference houses. The House Simulation Protocols report (Hendron and Engebrecht, 2010) includes guidelines and characteristics of reference homes including operating conditions, space conditioning, domestic hot water, lighting, appliances and other loads, occupancy, and internal mass. Characteristics of these reference homes can be used to study and assess energy impact of different on-site generators running an hourly simulation. End use results can be used to select the system that reduces home owner costs while enhancing energy efficiency and performance. Characteristics of CASHEM demonstration homes can be compared with that of BA reference homes ${ }^{1}$.

\subsubsection{State and National Renewable Energy Maps ${ }^{2}$}

The United States Environmental Protection Agency (EPA) and National Renewable Energy Laboratory (NREL) have developed renewable energy potential maps. These maps provide general information about the renewable energy potential of EPA tracked sites in the U.S. showing which renewable resources are most available in different regions in the U.S. These maps (shown in Figure 1.4-14 to Figure 1.4-21) show either utility scale or community scale power sources. Although these are not residential scale generation resources, they still provide a good idea about availability of wind, solar, and biomass in the country as well as each state.

Figure 1.4-14 shows the wind energy resource in a color coded ranking from poor to superb representing power class 1 to 7 which is based on amount of power produced per meter square (i.e., power density). For example, wind or power class 1 means resource potential is poor and power generation is from 0 to $200 \mathrm{~W} / \mathrm{m}^{2}$; power class 7 means wind resource potential is superb and power generation is above $800 \mathrm{~W} / \mathrm{m}^{2}$. Table 1.4-1 shows that a power class higher than 5 is required for on-site wind generation to be cost-effective in residential homes. There is almost no site with power class higher than 5 (i.e. wind power density between 500 to $800 \mathrm{~W} / \mathrm{m}^{2}$ ) for community wind energy generation potential in the region with higher market potential for smart appliances (identified in the previous section). This makes wind a poor choice for residential on-site power generator in this region.

Figure 1.4-15 shows community wind energy generation potential in Minnesota and Anoka, MN, where CASHEM demonstration homes are sited. The power class in Anoka is 2 and community wind energy generation potential seems to be "marginal" (i.e., wind power density between $200-300 \mathrm{~W} / \mathrm{m}^{2}$ ) in this area. One study ${ }^{3}$ shows that power class 2 has a payback time of 28 to 40 years and a net loss of $\$ 15,000$ to $\$ 25,000$ after 20 years for home use. Table 1.4-1 shows a summary of payback periods for a residential-sized Scirocco wind turbine ${ }^{4}$. Although there are U.S. based residential wind turbine manufacturers (e.g. Bergey Windpower Company ${ }^{5}$ ), the only study and source found related to payback time of different wind power classes was done by Solacity and for Scirocco wind turbine.

\footnotetext{
${ }^{1}$ There are advantages to this such as understanding retrofit options that may cost less than integration of on-site generation or comparing appliance load of reference homes with those installed in CASHEM demonstration homes ${ }^{2}$ Results shown on these maps are based on "site screening criteria adapted from NREL criteria and GIS data provided by NREL and EPA.

${ }^{3}$ http://www.solacity.com/Economics.htm\#EnergyPotential

${ }_{5}^{4}$ Scirocco wind turbines are manufactured by Eoltec/BFI, Nice, France. See http://www.eoltec.com/

${ }^{5}$ Small wind turbines for homes, farms and small businesses by Bergey, Norman, OK. See http://www.bergey.com/
} 


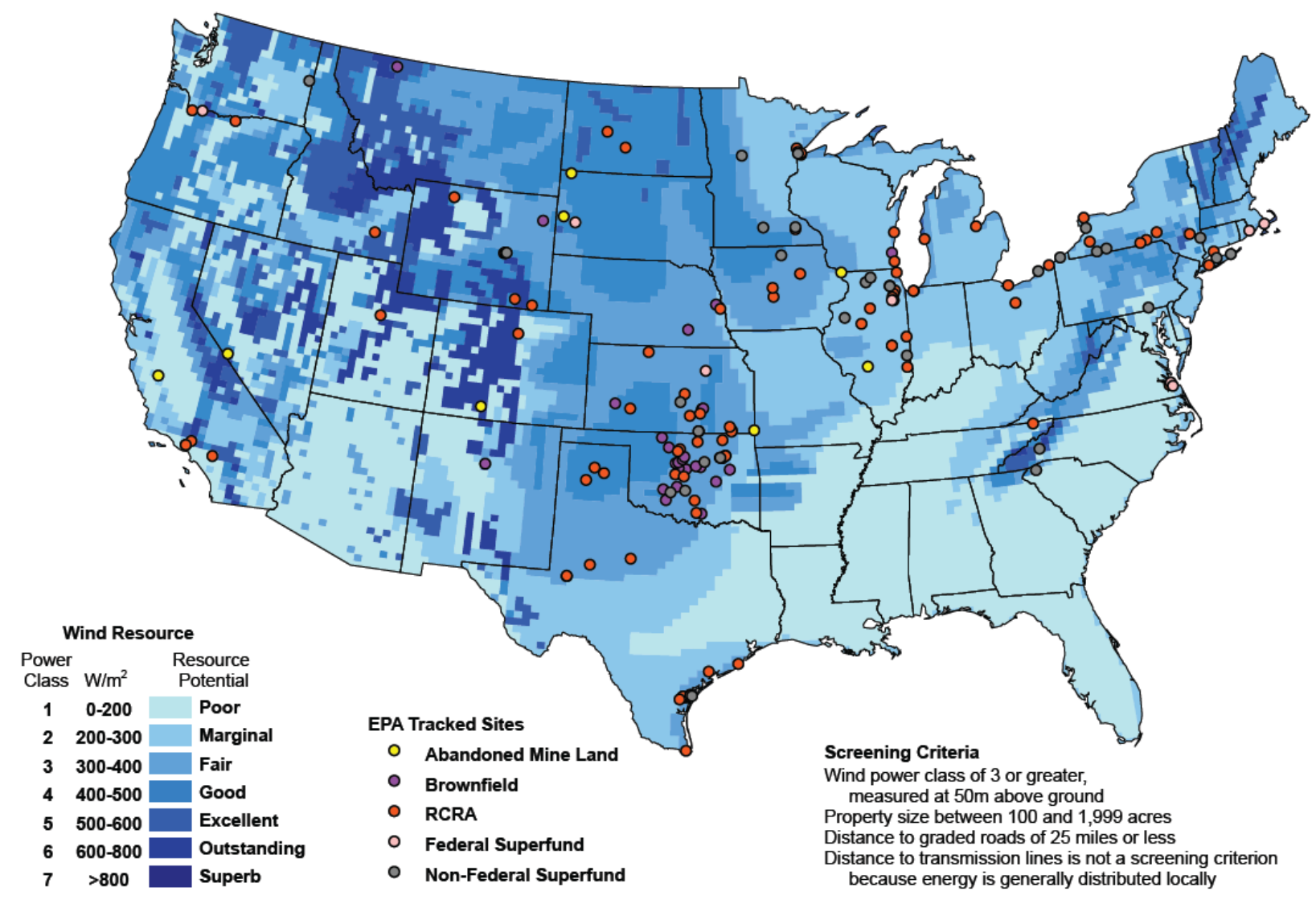

Figure 1.4-14. EPA tracked sites with community wind energy generation potential. Source: http://www.epa.gov/renewableenergyland/maps/pdfs/comm_wind_us.pdf

The map in Figure 1.4-16 shows EPA tracked sites with PV policy driven and utility scale PV solar energy generation potential. Solar resource potential is color-coded from moderate to excellent, which represents solar insolation ${ }^{1}$ of less than $3.5 \mathrm{kWh} / \mathrm{m}^{2} /$ day $^{2}$ to greater than $6 \mathrm{kWh} / \mathrm{m}^{2} /$ day. Figure $1.4-17$ shows the PV type available as: "utility only"; "PV policy driven only"; or "PV policy driven and utility scale PV". The region identified to have maximum potential for appliance replacement is also marked on the map in Figure 1.4-17 in the large oval overlay in the Midwest portion of the U.S. Based on this map, solar energy resource potential is "moderate" to "very good" in this overlay area meaning radiant solar energy reaching an area can be less than $3.5 \mathrm{kWh} / \mathrm{m}^{2} /$ day in some regions (e.g., north of Ohio and Illinois) and 5 to $6 \mathrm{kWh} / \mathrm{m}^{2} /$ day in some other region (e.g., west of Nebraska, Kansas and Oklahoma). Solar availability and cost-effectiveness of on-site solar generators is highly affected by average peak sun hours per day. A more detailed study is required to evaluate and calculate solar energy payback in each state. This is because different states have different incentives available which result in different payback periods. This report is limited to the city of Minneapolis, MN, which is closest to where the CASHEM demonstration homes are located.

\footnotetext{
${ }^{1}$ http://www.rurdev.usda.gov/SupportDocuments/OR-QuickGuide2SolarPV.pdf

2 This is also known as average peak sun hours per day, which is equal to number of hours per day that average solar irradiance is about $1,000 \mathrm{~W} / \mathrm{m}^{2}$.
} 


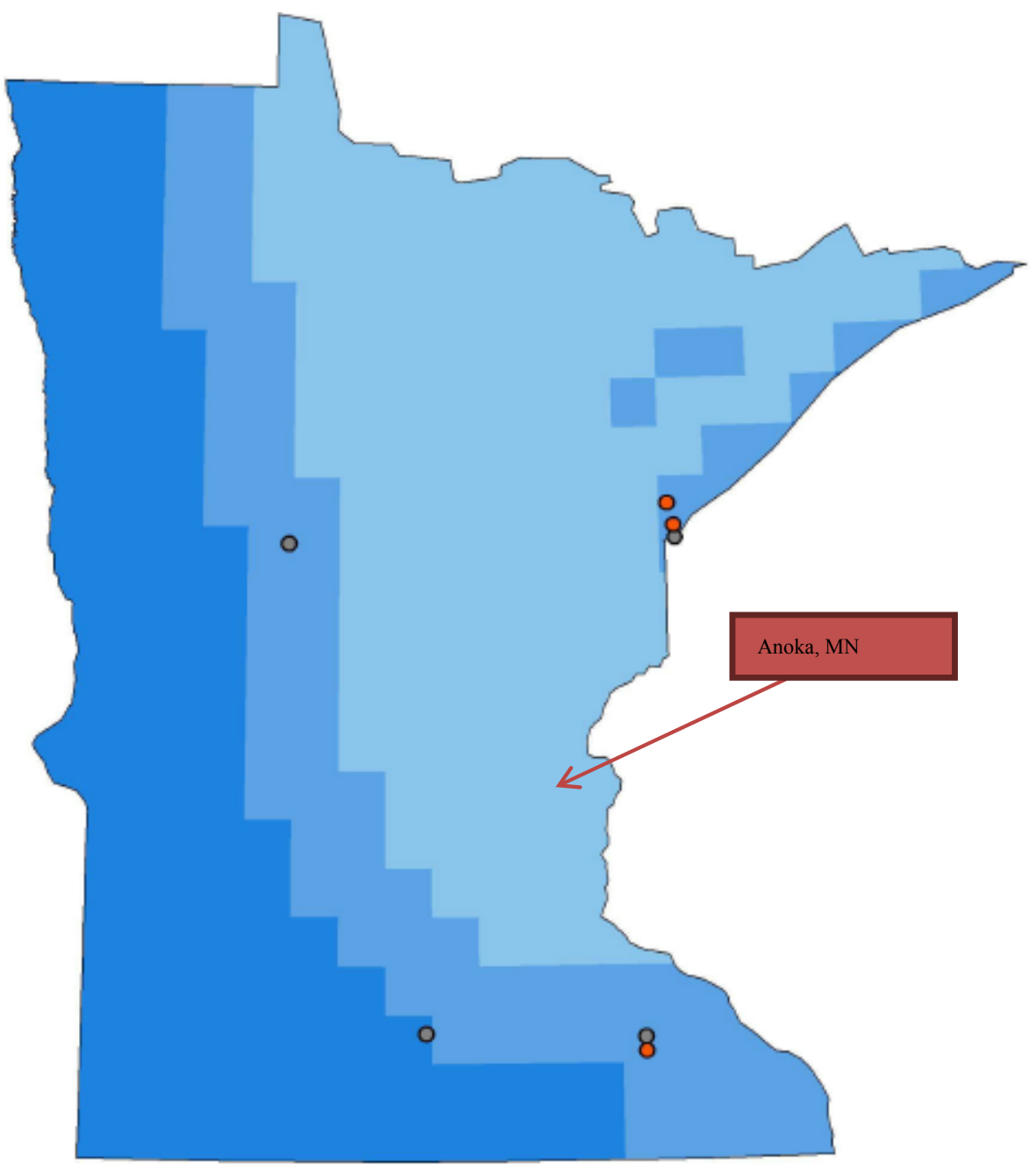

\section{Wind Resource}

\begin{tabular}{cc|l}
$\begin{array}{c}\text { Power } \\
\text { Class }\end{array}$ & W/m & Resource \\
\hline 1 & $\mathbf{0 - 2 0 0}$ & Potential \\
2 & $\mathbf{2 0 0 - 3 0 0}$ & Poor \\
3 & $\mathbf{3 0 0 - 4 0 0}$ & Marginal \\
4 & $\mathbf{4 0 0 - 5 0 0}$ & Fair \\
$\mathbf{5}$ & $\mathbf{5 0 0 - 6 0 0}$ & Good \\
$\mathbf{6}$ & $\mathbf{6 0 0 - 8 0 0}$ & Excellent \\
7 & $>800$ & Outstanding \\
& & Superb
\end{tabular}

\section{EPA Tracked Sites}

- Abandoned Mine Land

- Brownfield

- RCRA

- Federal Superfund

- Non-Federal Superfund

\section{Screening Criteria}

Wind power class of 3 or greater, measured at $50 \mathrm{~m}$ above ground Property size between 100 and 1,999 acres Distance to graded roads of 25 miles or less Distance to transmission lines is not a screening criterion because energy is generally distributed locally

Figure 1.4-15. EPA tracked sites in Minnesota with community wind energy generation potential. Source: http://www.epa.gov/renewableenergyland/maps/pdfs/comm_wind mn.pdf 
Table 1.4-1. Scirocco wind turbine payback. Source:

http://www.solacity.com/Economics.htm\#EnergyPotential

\begin{tabular}{|c|c|c|c|c|c|}
\hline \multirow{2}{*}{$\begin{array}{l}\text { Wind } \\
\text { Class }\end{array}$} & $\begin{array}{c}\text { Annual } \\
\text { Production }\end{array}$ & $\begin{array}{c}\text { Payback, } \\
\text { Years }\end{array}$ & $\begin{array}{c}\text { Profit or (Loss) after 20 } \\
\text { Years }\end{array}$ & $\begin{array}{c}\text { Payback, } \\
\text { Years }\end{array}$ & $\begin{array}{c}\text { Profit or (Loss) after 20 } \\
\text { Years }\end{array}$ \\
\hline 1 & $0-\$ 1,293$ & $24-$ infinity & $(\$ 31,000)-\$-6,000$ & $40-$ infinity & $(\$ 51,000)-(\$ 25,000)$ \\
\hline 2 & $\$ 1,293-\$ 1,803$ & $17-24$ & $(\$ 6,000)-\$ 5,000$ & $28-40$ & $(\$ 25,000)-(\$ 15,000)$ \\
\hline 3 & $\$ 1,803-\$ 2,155$ & $15-17$ & $\$ 5,000-\$ 12,000$ & $24-28$ & $(\$ 15,000)-(\$ 8,000)$ \\
\hline 4 & $\$ 2,155-\$ 2,442$ & $13-15$ & $\$ 12,000-\$ 17,000$ & $21-24$ & $(\$ 8,000)-(\$ 3,000)$ \\
\hline 5 & $\$ 2,442-\$ 2,697$ & $12-13$ & $\$ 17,000-\$ 22,000$ & $19-21$ & $(\$ 3,000)-\$ 3,000$ \\
\hline 6 & $\$ 2,697-\$ 3,048$ & $10-12$ & $\$ 22,000-\$ 29,000$ & $17-19$ & $\$ 3,000-\$ 10,000$ \\
\hline 7 & $\$ 3,048-\$ 4,054$ & $8-10$ & $\$ 29,000-\$ 50,000$ & $13-17$ & $\$ 10,000-\$ 30,000$ \\
\hline
\end{tabular}
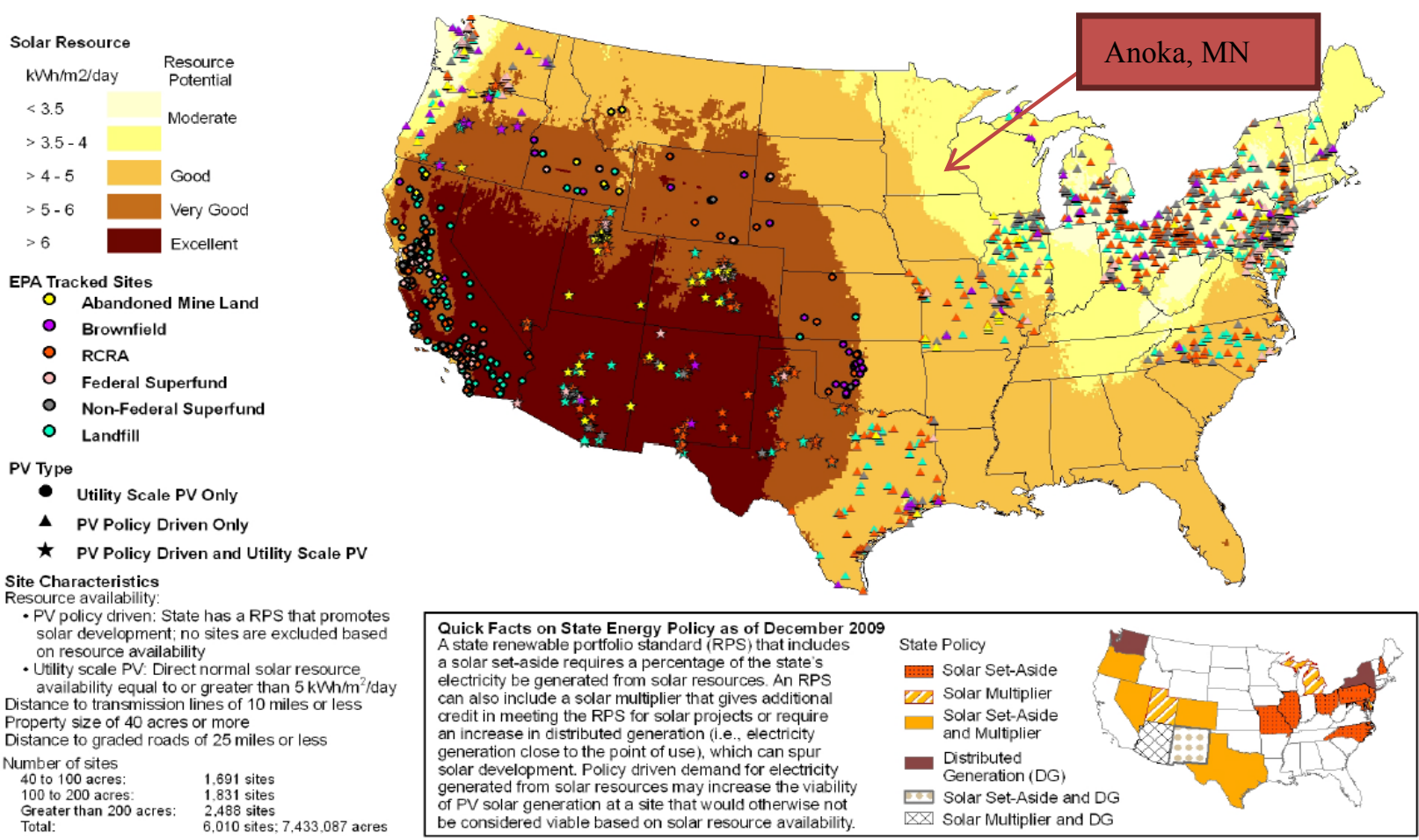

Figure 1.4-16. EPA tracked sites with PV policy driven and/or utility scale PV solar energy generation potential. Source:

http://www.epa.gov/renewableenergyland/maps/pdfs/pv_utility_policy_us.pdf

Anoka, MN is marked in Figure 1.4-16 and it appears the resource potential is "moderate" in Anoka. Department of Natural Resources in Minnesota has provided a solar energy payback calculator ${ }^{1}$, which can be used to estimate net present value and payback on an investment in solar PV system. A snapshot of the calculator is shown in Figure 1.4-17. The results are for a residential PV system size of 10KW and it shows that the payback period is about 13 years. PV modules have a long life cycle of about 25 to 30 years, which makes the PV system in this example cost-effective.

${ }^{1}$ http://www.dnr.state.mn.us/energysmart/why/calculator.html 


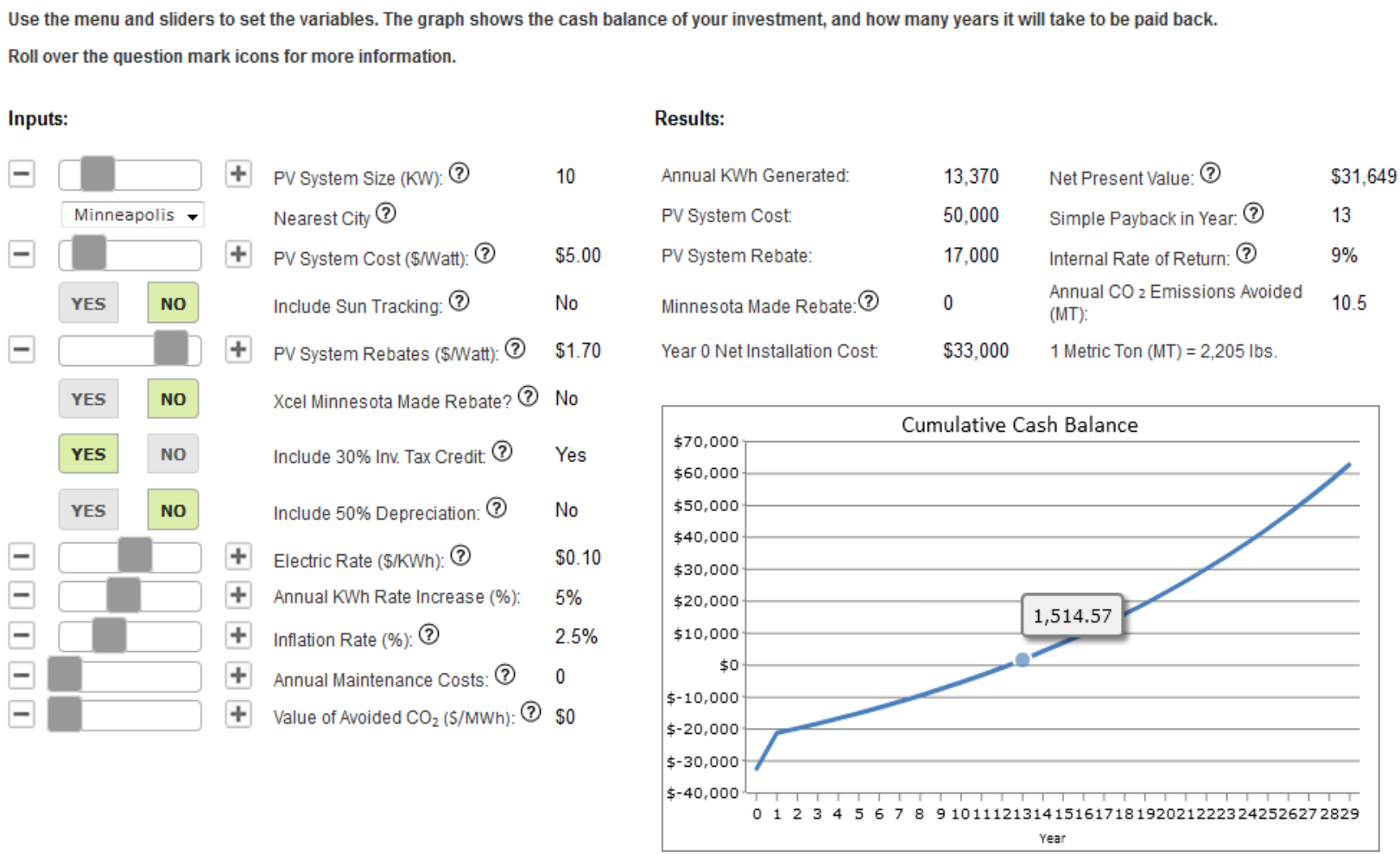

Figure 1.4-17. Solar energy payback calculator for 2012-2013 for Minneapolis, MN

Figure 1.4-18 and Figure 1.4-19 show EPA tracked sites with biopower and biorefinery siting potential in the U.S. and Figure 1.4-20 and Figure 1.4-21 show these facility potentials in Minnesota. Availability of these resources is "good" to "outstanding" in the region identified to have high potential for appliance replacement. Despite its availability, biomass-based fuel is not currently used as residential fuel as shown in the U.S. energy flow chart prepared by DOE (Figure 1.4-22). One key reason for no or little use of biofuels in the residential sector is the lack of a robust transmission and distribution system which is currently primarily dependent upon surface (road and rail) transportation. The U.S. energy flow chart shows that after petroleum, natural gas is the most used fuel and accounts for about $45 \%$ of residential energy source. Availability of natural gas, as shown in Figure 1.4-23, and the extensive transmission and distribution system allow for widespread use in the residential sector throughout the U.S. This distribution system combined with its low cost makes it the most favorable residential fuel today and for the foreseeable future. 


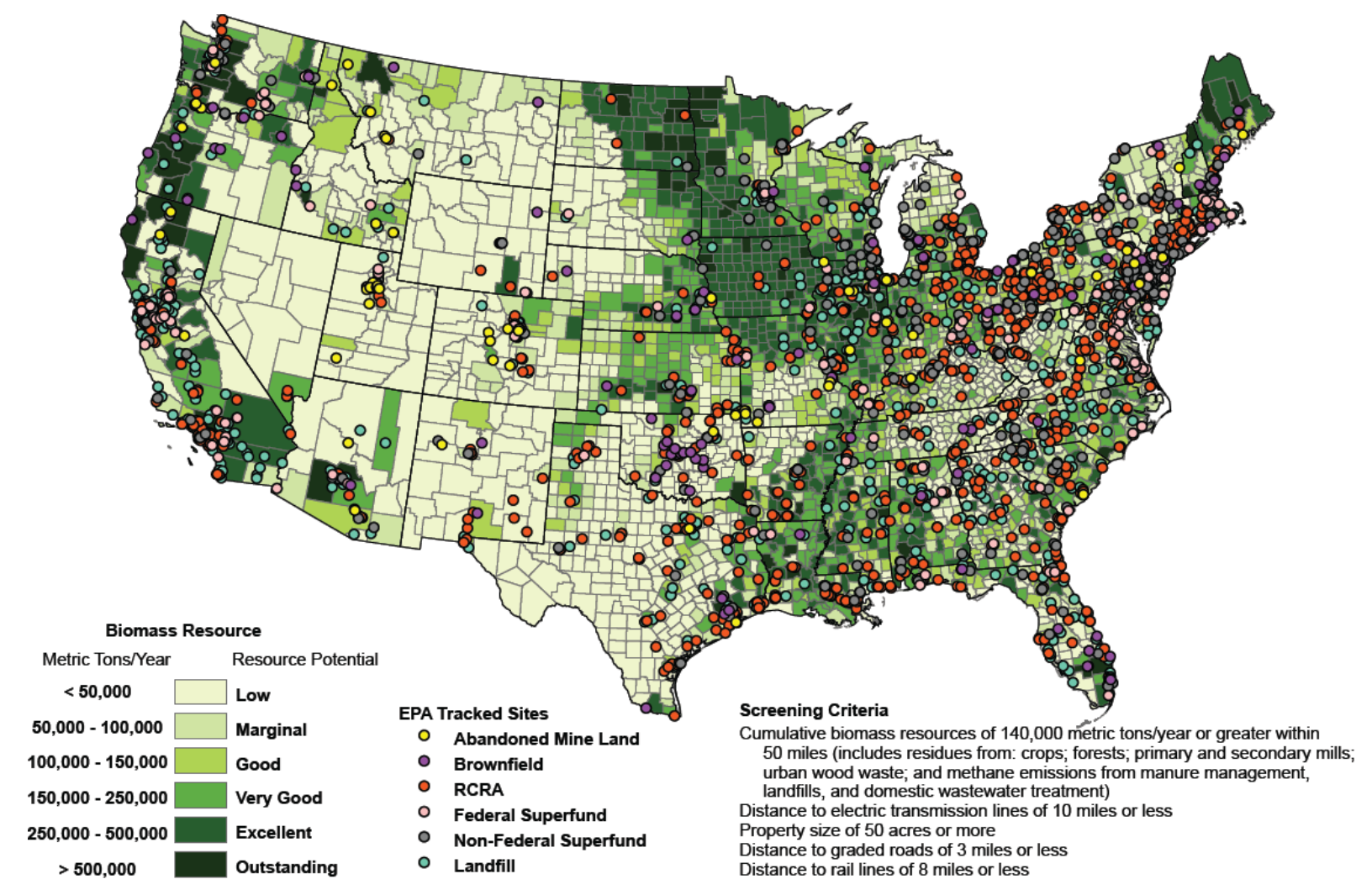

Figure 1.4-18. EPA tracked sites with biopower facility siting potential

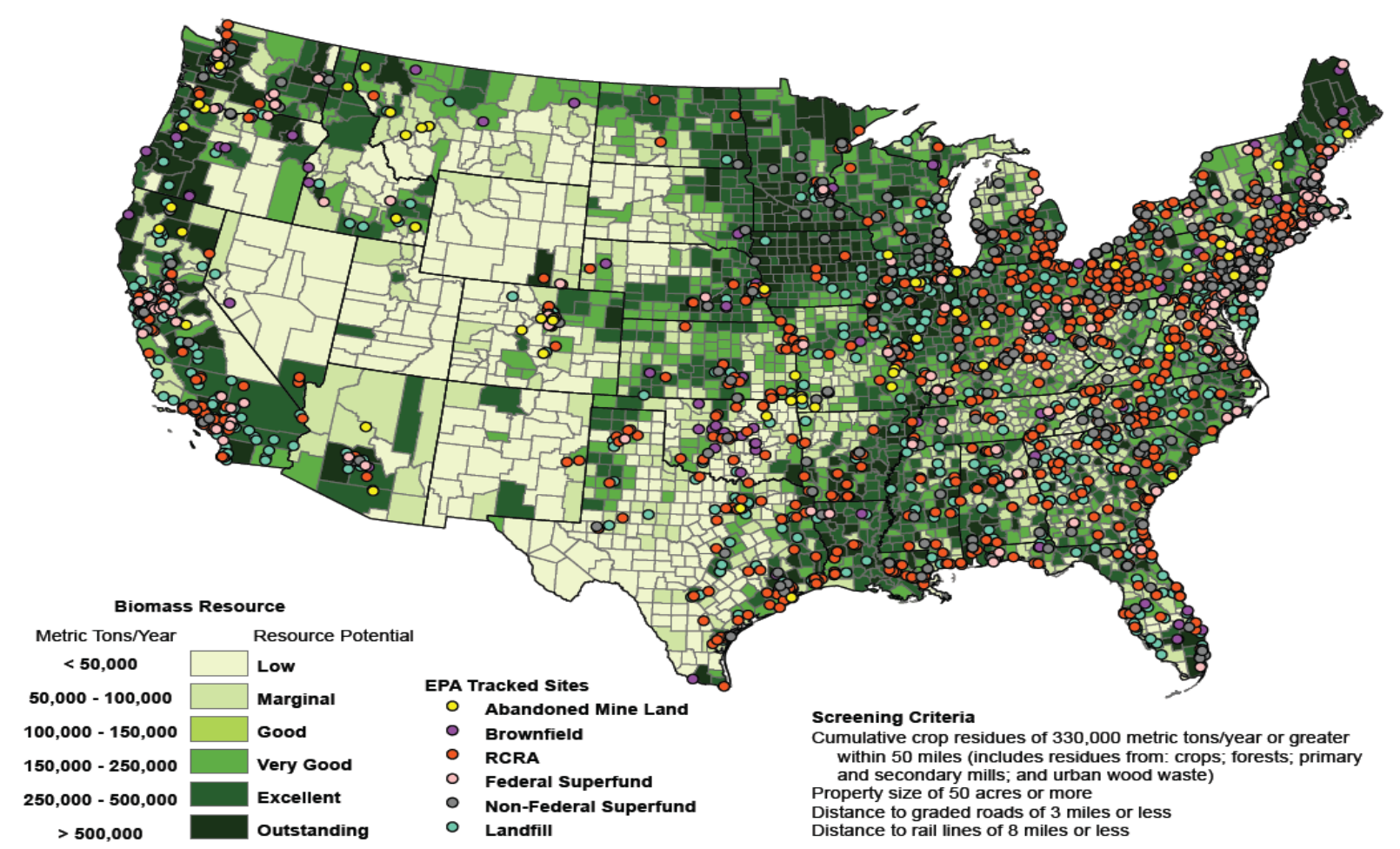

Figure 1.4-19. EPA tracked sites with biorefinery facility siting potential. Source: http://www.epa.gov/renewableenergyland/maps/pdfs/biorefinery us.pdf 


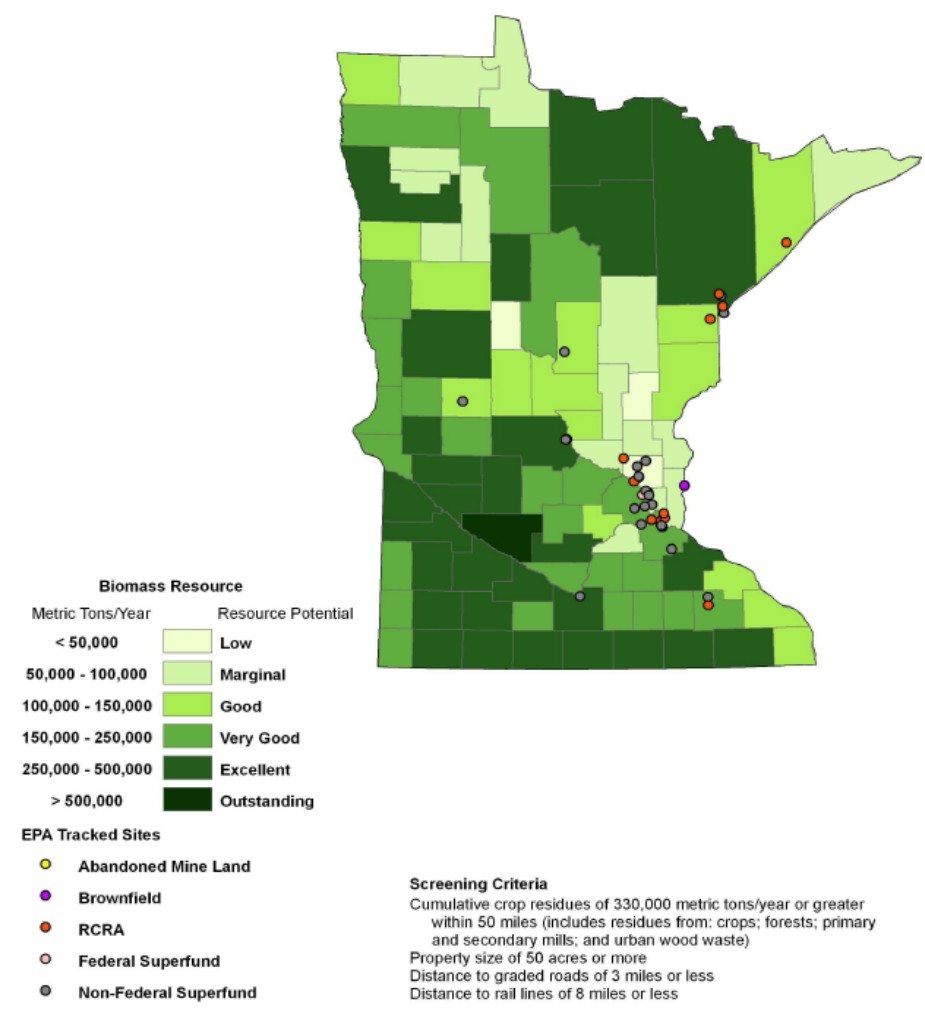

Figure 1.4-20. EPA tracked sites in Minnesota with Biorefinery facility siting potential.

Source: http://www.epa.gov/renewableenergyland/maps/pdfs/biorefinery_mn.pdf

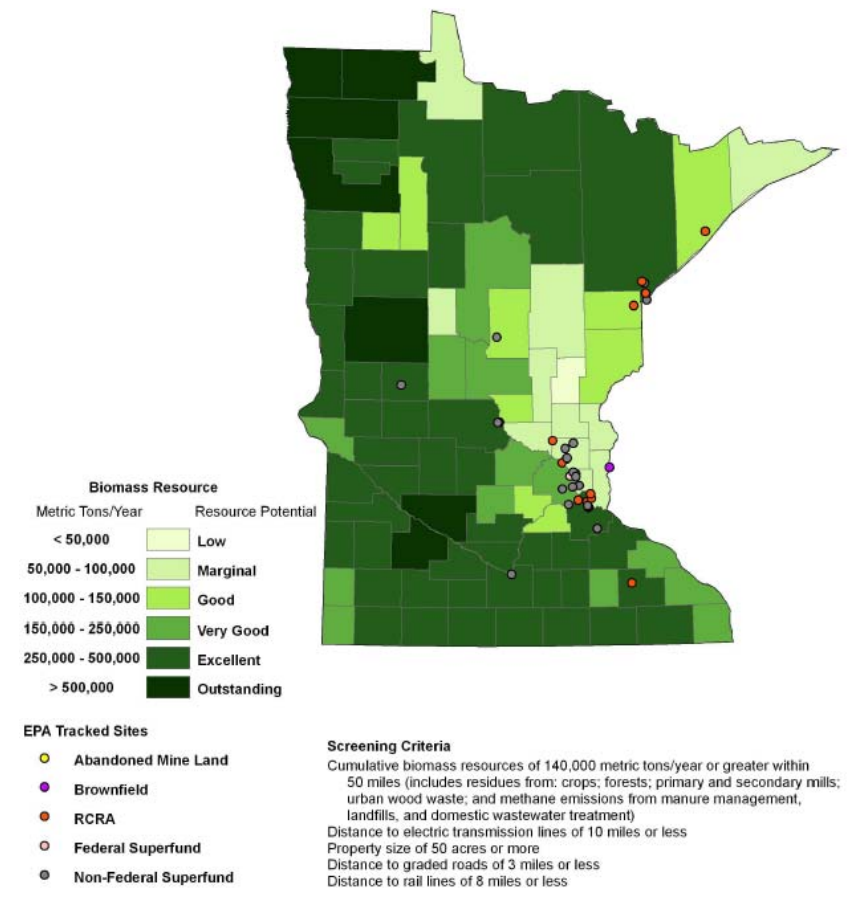

Figure 1.4-21. EPA tracked sites in Minnesota with Biopower facility siting potential.

Source: http://www.epa.gov/renewableenergyland/maps/pdfs/biopower_mn.pdf 


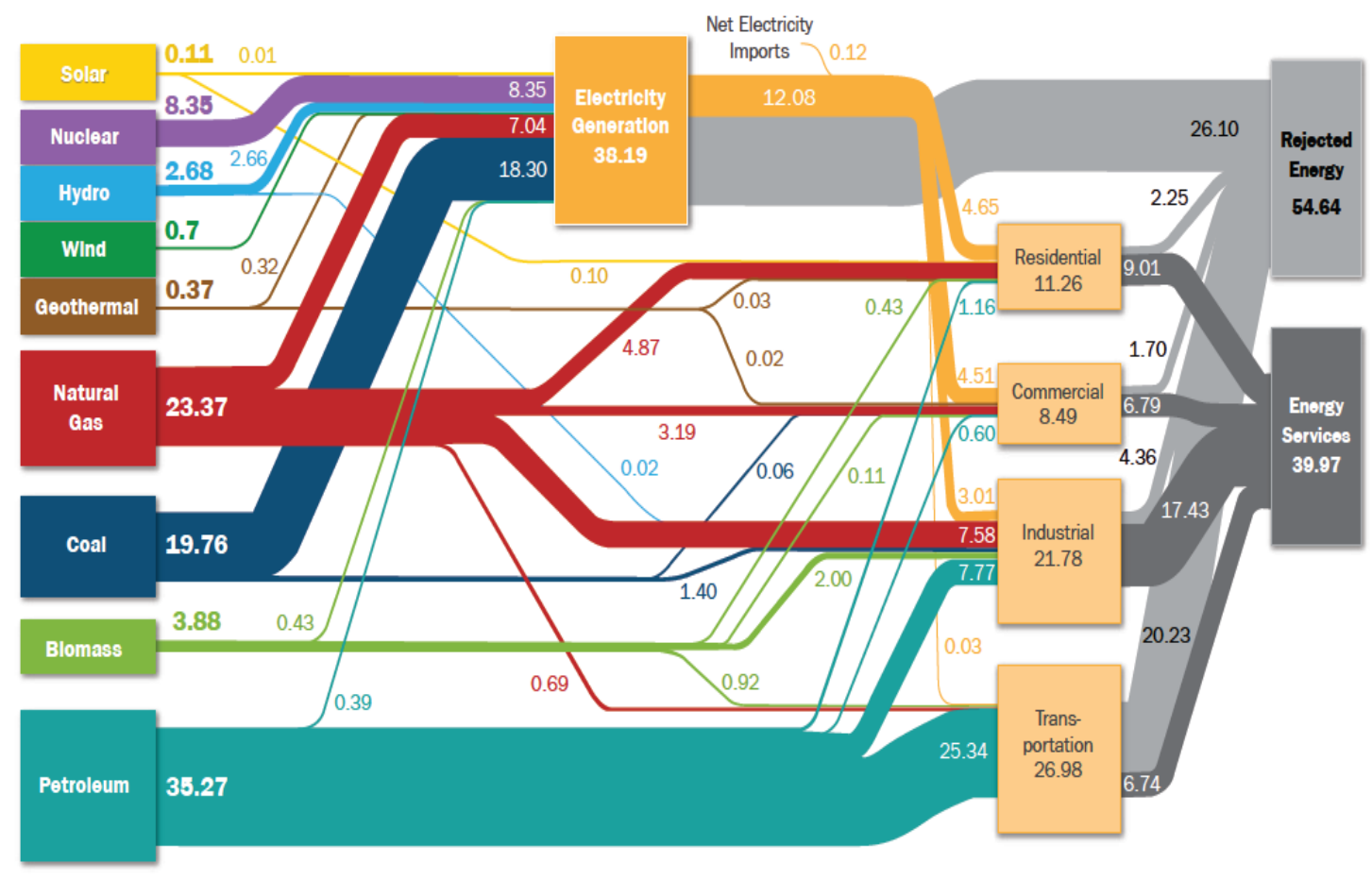

Figure 1.4-22. U.S. energy flow in 2009. Source: Department of Energy. (2011) Report on the first quadrennial technology review (QTR), Washington, DC.

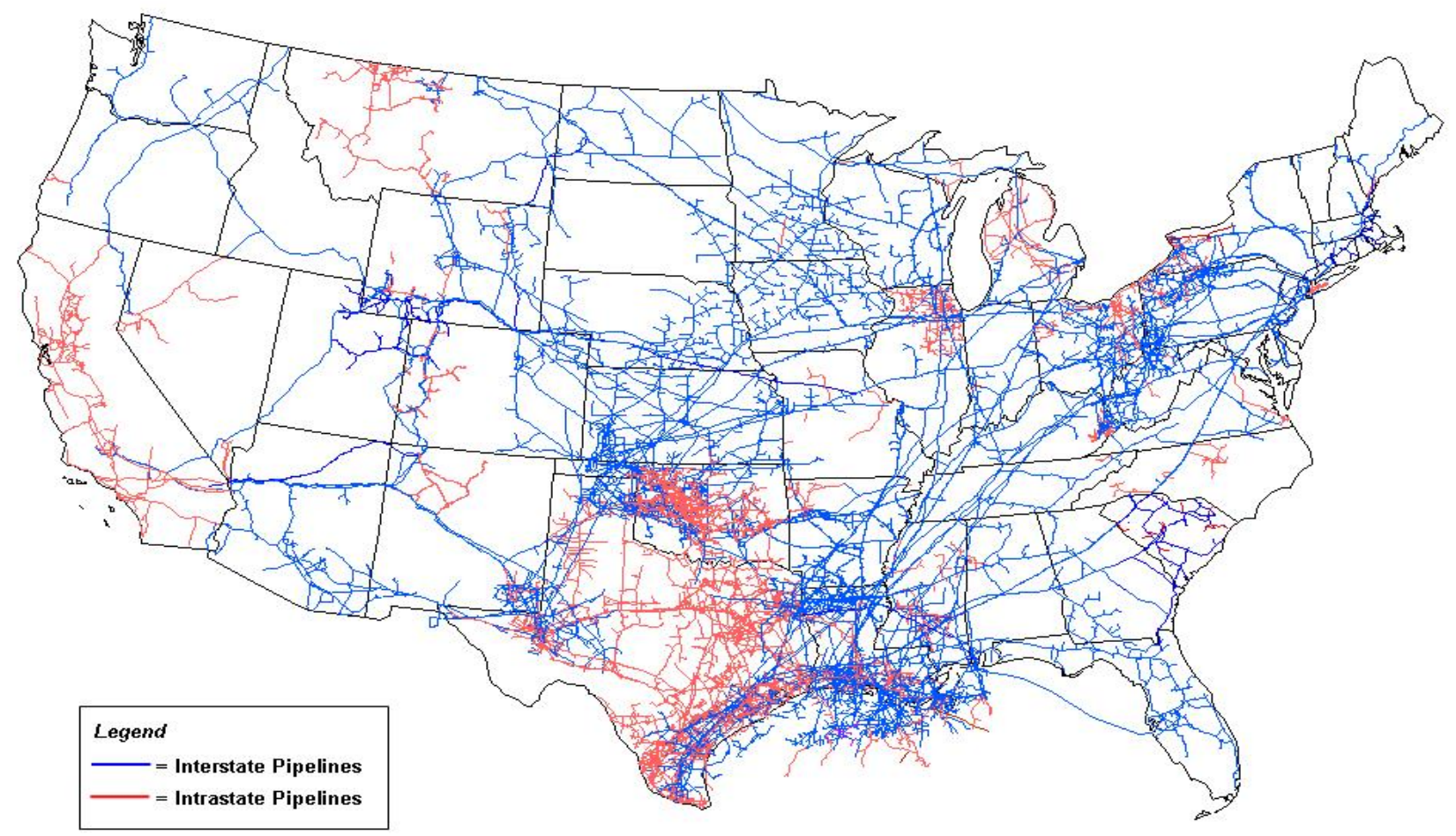

Figure 1.4-23. U.S. natural gas pipeline network, 2009.

Source: http://www.eia.gov/pub/oil_gas/natural_gas/analysis_publications/ngpipeline/ng pipelines map.html 


\subsubsection{Conclusions}

In this section, the concentration of electric home appliances that have maximum replacement potential was identified in the U.S.. This study was based on year of construction of homes, census region, climate region and household income. The geographical concentration of these appliances was found and marked on the ASHRAE climate zone map shown in. It was also found that most clothes washers with replacement potential are located in homes constructed 1970 to 1979, most refrigerators and clothes dryers are in homes constructed between 1980 to 1989, and the rest (i.e. dishwashers and water heaters) are in houses constructed between 1990 to 1999. Another finding was the number of households with income higher than $\$ 100,000.00$ in different U.S. regions. Based on RECS data, households with this range of income are most concentrated in South followed by West, Northeast and Midwest. This information helps identifying the potential market for smart appliances by geographic location, household type and income level.

The market for the down-selected on-site power generators was characterized in Task 1.3 based on potential, availability of resources in different regions, cost, and payback period. It was found that wind is the least available and least cost-effective resource among other energy resources for residential sector. Natural gas is the most available with least cost, which makes it the most favorable fuel for on-site power generation. That makes internal combustion and fuel cell more cost-effective than solar and wind as onsite power generators. Refer to the cost study in Task 1.3 for the ranking of these technologies.

\subsection{Data Analysis to Determine User Preference and Type Characteristic}

\subsubsection{Introduction}

The objective of this task is to perform a literature review and analyze data available (e.g., FSEC) to find user (occupant) characteristics based on different energy consumption behaviors observed daily and weekly. This should help understand what CASHEM capabilities are most effective in reducing energy consumption while maintaining occupants comfort and satisfying their preferences as much as possible based on their life style and other characteristics (e.g., economic considerations, etc.). Understanding and determining user preference and type characteristics will also assist with deriving influential recommendations to help occupants make more informed decisions about how they use energy and operate their home.

\subsubsection{Research Questions}

This literature review and research focuses on the following questions:

1. How much energy can be saved by providing feedback and recommendations to home occupants?

2. Do user behavior and type characteristics affect energy use profile?

3. What is the best process to derive user preference-based recommendations?

4. How can CASHEM be used to strike a balance between satisfying user preference while saving energy? 


\subsubsection{Background}

Occupant feedback programs started as early as 1974 and have attracted more and more attention in the past decade. Table 1.5-1 shows a summary of feedback programs available for residential sector in North America. The programs included are based on those discussed in a report by Friedrich et al. (2010); a case study done for American Council for an Energy-Efficient Economy to understand effective behavioral approaches to improve consumer energy efficiency.

There has been much research done examining the effectiveness of continuous electricity use feedback on energy consumption via a display monitor. Appliance load monitoring and energy feedback was tested as early as 1979 by McClelland \& Cook (Darby, 2006). Their experiment showed 12\% energy consumption reduction as a result of electricity use feedback. Darby (2006) also studied the effectiveness of energy feedback and reported 5-15\% energy reduction from direct feedback via a display monitor. The same study shows that energy savings go as high as $20 \%$ with pay-as-you-go systems in North America (Darby, 2006). A pay-as-you-go ${ }^{1}$ program was initially started in the U.S. by Salt River Project (SRP) in Arizona in 1993 with the intention to help low-income customers with their bills while conserving energy by prepaying for electricity (Neenan, 2010). The pre-paid program, which is known as the M-power program started with a 100 home pilot to give more control to consumers over their electricity bill by prepaying for an amount of electricity they choose ${ }^{2}$. In April 2010, the number of customers enrolled in the M-Power program reached over 100,000 and is not just limited to low-income users. Customers also join the program with energy conservation intentions. There are currently over 110 SRP PayCenter machines in Phoenix area (SRP, 2012).

Allen \& Jonda (2006) performed a more comprehensive literature review on the effects of real-time energy use feedback and concluded that raising awareness by providing real-time energy use feedback can affect consumer behavior towards use of energy. They also mentioned that consumers respond more strongly to large collective energy use data rather than micro data. Therefore, weekly or monthly data might have more impact on consumer behavior. There are other studies that have evaluated the impact of the current generation of energy display/feedback technologies (such as that from OPower) and there are more data that are just now becoming public.

\footnotetext{
${ }^{1}$ A pre-pay program is a prepayment plan that gives consumers the opportunity to buy energy in the amount they want from Pay Machines that look like an ATM. Using M-Power display, the consumer can see how much of the energy purchased has been used and the remaining credit in the dollar amount. It would also show an estimate of the number of days remaining before energy credit runs out. The system recommends user to purchase additional energy credit when enough credit for about four days is left. A "warning" message also appears if the credit is too low. Other information displayed include: the amount of energy used in the last hour expressed in dollars, amount of energy currently being used in $\mathrm{kWh}$, the amount of energy used since midnight in dollars, the amount of energy used on the previous day and month (in dollars), and current energy rate. Therefore, the user can see how changing thermostat setpoint as well as other energy saving activities would affect amount of energy being used.

${ }^{2}$ SRP M-Power Price Plan: http://www.srpnet.com/payment/mpower/default.aspx.
} 
Table 1.5-1. List of feedback programs (Friedrich et al., 2010).

\begin{tabular}{|c|c|c|}
\hline Program & Program Description & Findings $^{1}$ \\
\hline $\begin{array}{l}\text { Residential smart energy } \\
\text { monitoring pilot (Cape Light } \\
\text { Compact) }\end{array}$ & $\begin{array}{l}\text { This program used data from home } \\
\text { energy monitoring systems. }\end{array}$ & $\begin{array}{l}\text { On average participants achieved a } \\
9.3 \% \text { energy use reduction during the } \\
12 \text { month pilot period. }\end{array}$ \\
\hline Flex your power ${ }^{(b)}$ & $\begin{array}{l}\text { This was a state-wide media and } \\
\text { outreach program in California. }\end{array}$ & Not available. \\
\hline $\begin{array}{l}\text { Home energy reporting } \\
\text { program (e.g. OPOWER) }\end{array}$ & $\begin{array}{l}\text { This program works by delivering } \\
\text { personalized energy reports that } \\
\text { include recommendations and tips to } \\
\text { reduce energy use. }\end{array}$ & $\begin{array}{l}\text { Resulted in energy use reduction of } \\
2.4 \% \text { during a } 16 \text {-month period. }\end{array}$ \\
\hline SPR M-Power program ${ }^{(\mathrm{d})}$ & Pay-as-you-go (i.e. pre & $\begin{array}{l}\text { Resulted in energy use reduction of } \\
12 \% \text { on average. }\end{array}$ \\
\hline $\begin{array}{l}\text { Real-time monitoring pilot } \\
{\text { (Hydro One })^{(e)}}\end{array}$ & $\begin{array}{l}\text { This program uses informational } \\
\text { strategies and time-of-use pricing to } \\
\text { encourage consumers to save power. }\end{array}$ & $\begin{array}{l}\text { Resulted in energy use reduction of } \\
6.5 \% \text { on average. }\end{array}$ \\
\hline $\begin{array}{l}\text { Building operator certification } \\
(\mathrm{BOC}) \text { program }^{(\mathrm{f})}\end{array}$ & $\begin{array}{l}\text { The BOC program is offered in } 22 \\
\text { states. (this program involves energy } \\
\text { management in multi-family housing } \\
\text { rather than single-family homes) }\end{array}$ & $\begin{array}{l}\text { Savings of about } 9.2 \text { million } \mathrm{kWh} \text { of } \\
\text { electricity and } 35,000 \text { therms of gas } \\
\text { was achieved resulting from } 2,300 \mathrm{~kW} \\
\text { demand reduction. }\end{array}$ \\
\hline \multicolumn{3}{|c|}{$\begin{array}{l}\text { (a) http://www.capelightcompact.org/library/2010/08/3.31.10-Residential-Smart-Home-Energy-Monitoring- } \\
\text { Final-Evaluation-Report.pdf } \\
\text { (b) } \underline{\mathrm{http}: / / \text { www.fypower.org/ }} \\
\text { (c) http://opower.com/what-is-opower/reports } \\
\text { (d) http://www.srpnet.com/payment/mpower/default.aspx } \\
\text { (e) } \underline{\mathrm{http}: / / \mathrm{www} \cdot h y d r o o n e . c o m / \text { Pages/Default.aspx }} \\
\text { (f) } \underline{\mathrm{http}: / / \text { www.theboc.info/ }}\end{array}$} \\
\hline
\end{tabular}

NREL also did a review on engaging households and savings resulted through smart feedback based on studies done by Ehrhardt-Martinez (2010 and 2011). This review was based on 61 research studies and 57 feedback initiatives that took place in 9 countries. Out of 58 studies conducted, 33 took place in the United States. In this review, the feedback program research was divided into two eras of energy crisis (from 1974 to 1994) and climate change (from 1995 to 2010). Savings resulted from these historical programs show that direct feedback in real-time results in more energy savings when compared to indirect feedbacks provided after energy was consumed. Also, maximum savings can be achieved by providing recommendations in addition to real-time energy consumption feedback. Result from historical feedback research was summarized as shown in Figure 1.5-1.

\footnotetext{
${ }^{1}$ Savings reported are greatly affected by type of space heating and water heating (i.e., larger reductions would be observed in homes with non-electric water heating or space heating)
} 


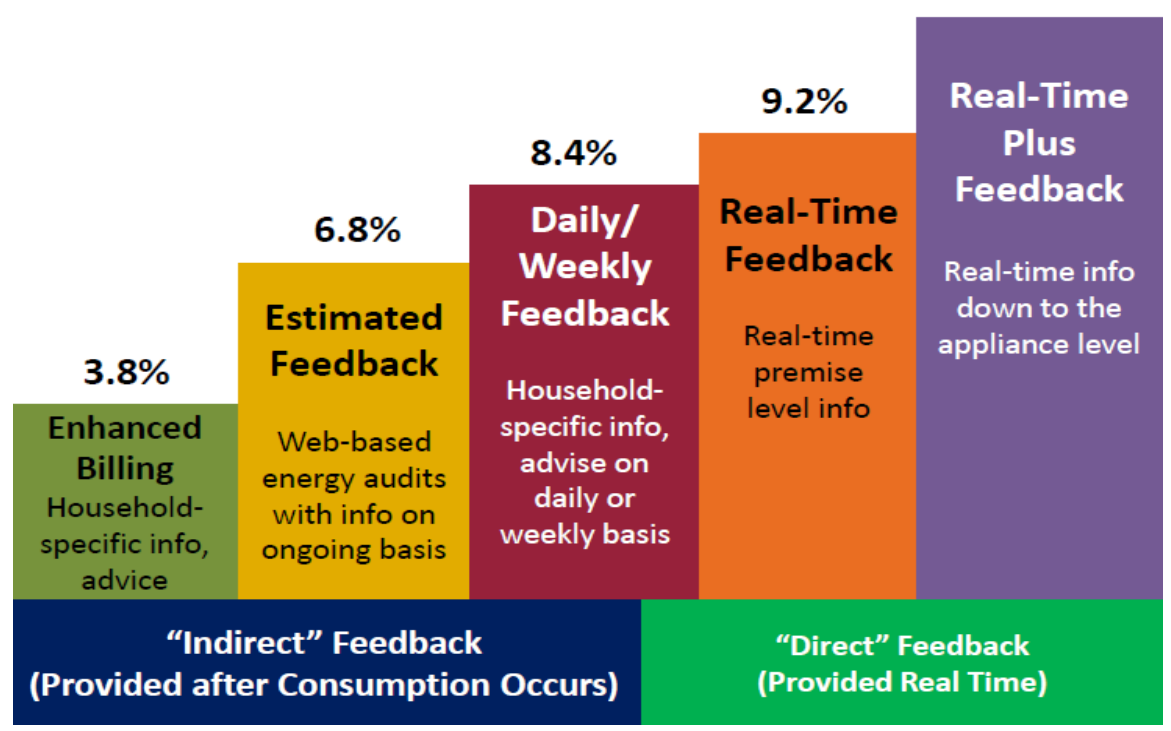

Figure 1.5-1. Average savings resulted from historical feedback programs (Source: http://www.nrel.gov/tech_deployment/state_local_activities/pdfs/tap_webinar_20110728 martinez.pdf)

One of the main objectives of feedback study by NREL was to find out if feedback is more effective when combined with social science insights. Findings showed that there are several non-economic motivation strategies that can increase energy savings resulted from feedback. These strategies include social norms ${ }^{1}$, goal setting ${ }^{2}$, commitments ${ }^{3}$, and social context ${ }^{4}$ (Ehrhardt-Martinez, 2011). According to other studies, social norms can affect energy savings by $2-10 \%$, goal setting can reduce energy consumption by $5-17 \%$, and commitments by $5-8 \%$. Another factor studied by Peterson et al. (2007) was 'competition'. A competitive program that engages people in a more social interaction with peer groups of similar profile (e.g. location, size of household, and etc.) can result in 10-32\% energy savings. Peterson's study used aggregate, real-time feedback in several dormitories in Oberlin University to set up a competition between different groups of students and advertised a reward (i.e. incentive) for the winner who achieves maximum amount of energy savings. This study showed that not many people showed up for the reward's party although they had participated in energy saving activities. This study concluded that the main motive in saving energy was therefore not the incentive/reward but the social interaction and the challenge involved in the saving energy activities required.

Therefore, feedback and recommendation programs should be formulated in a way that set up 'norms' and motivate people to evaluate their behavior regarding energy consumption. Recommendations should also be goal-oriented, competitive and make people more committed to energy savings. This can be achieved by displaying not only the occupant's energy use profile, but also providing consumption of 'peer groups' (i.e., neighbors with similar status, building size, and preferences).

\footnotetext{
${ }^{1}$ People tend to question their behavior if they find it not to be 'normal'.

${ }^{2}$ People are normally goal-oriented and they need to define what they are trying to achieve and evaluate their progress towards accomplishing that goal.

${ }^{3}$ People normally want to be known as responsible and accountable. "Commitments help people to ensure that their actions are consistent with their ideals (Ehrhardt-Martinez, 2011)."

${ }^{4}$ People normally learn from each other and through that they get support, approval and encouragement as well.
} 
Feedback related studies prove that load monitoring and displaying as well as feedback programs make energy use more visible to customers and have greater impact on energy use reduction. On the other hand, preference modeling and user modeling (Zukerman and Albrecht, 2000) have not been explored in the area of HEM and it has been used for objectives other than energy savings. In the energy industry, such models are used to estimate and predict the electricity demand profile (Yamaguchi et al, 2011) using daily and weekly activities performed. These models have been employed to convert 'behavior' to 'energy consumption'. This is useful when there is no empirical energy consumption (i.e., metered data) available.

User preference modeling may also be used to provide adequate services according to the preference of multi-users in a smart home (Lin and $\mathrm{Fu}, 2007$ ). Although this assists with operation of appliances according to different preferences each user has, it does not really aid with energy saving or shifting load. Other uses of occupant preference modeling include employment in building performance simulation tools for better prediction of energy use (Hoes et al., 2009) and control strategies (Herkel et al., 2008; \& Yun and Steemers, 2008). These control strategies would be beneficial if there is a thermostat that could be automatically adjusted based on previous behavior of the user or to control window operation for natural ventilation.

Predictive statistical models for user modeling such as Markov Models, Neural Networks, Rule Induction, and other methods summarized and reviewed by Zukerman and Albrecht (2000) can be explored in the area of HEM. These models take advantage of observed historical data and use these as sample results to provide recommendations about future actions. Therefore these recommendations represent some aspects of a user's future behavior such as goals and preferences (Zukerman and Albrecht, 2000). However, deployment of these models in the area of HEM has limitations because user previous actions and preferences are not necessarily in line with goals of energy conservation and therefore they cannot be used as samples to train statistical models. Another limitation is that user interventions are usually required to operate home appliances. For example, the dishwasher or clothes washer is normally loaded before it is operated.

The objective of this research is to better understand user preference in terms of appliances' time of operation and use in addition to the type of user to provide context-aware smart recommendations. Such recommendations should optimize occupant comfort/satisfaction while reducing use of energy.

\subsubsection{User Type Characterization}

Gram-Hanssen (2011) raised the question whether user behavior is as important as energy efficiency (e.g., more efficient windows or appliances) when it comes to energy conservation. This study showed that user practice (e.g., lighting and appliance operation) has more impact on energy savings compared to the inherent energy efficiency of technologies ${ }^{1}$. However, analysis related to energy consumption of residential heating and cooling revealed that user practices are almost as important as building physics and energy efficient systems (Gram-Hanssen, 2011). The leading factors affecting amount of energy usage in homes are the number of occupants, income, and the size of the house. The $\mathrm{kWh} /$ Btu per person is lower in homes that have more than one occupant even though total energy consumption is higher (Gram-Hanssen, 2011).

\footnotetext{
${ }^{1}$ One possible reason could be the 'rebound effect'. The rebound effect is the increase use of a commodity such as energy as a result of reduction in operating costs due to efficiency improvements thereby reducing the observed (energy) savings achieved.
} 
Different studies show that income is the second factor influencing baseline energy use in residential buildings. Nevertheless, findings are not consistent when it comes to energy conservation behavior in response to energy use feedback (Brandon \& Lewis, 1999; Gram-Hanssen, 2011; Heslop, Moran \& Cousineau 1981; Matsukawa 2004). One explanation is that average low-income consumers might be using energy conservatively enough and high-income consumers might prefer to just invest in some energy-efficient appliances rather than adjusting their behavior by responding to feedback and recommendations (Cunningham \& Joseph, 1978). Also, consumers with higher income are in general more aware of environmental concerns, but this general awareness and concern for the environment may not necessarily affect their personal energy usage pattern (Heslop, Moran \& Cousineau 1981). It should be noted that these studies go back to more than thirty years ago. However, in recent years there have been more efforts in raising general public awareness about energy conservation. There have been more technological advancements as well as educational advertisements to affect consumers' attitude towards energy consumption.

Allen \& Jonda (2006) also studied the effects of user behavior on energy consumption when energy use feedback is provided. Their research indicated that "when thinking about energy feedback, it is important to consider that certain characteristic differences between consumers may cause some to be generally more receptive to feedback than others." In their study, they considered income and attitudinal differences' as factors that influence effectiveness of energy use feedback. Attitude is not the same as behavior, but a "dynamic factor in the motivation and inducement of behavior" and "they have proven to be highly resistant to change" according to Naesje et al. (2005).

Naesje et al., (2005) tried to capture consumer attitude towards different factors that affect energy use. The dimensions considered in order to have better understanding of attitude include comfort vs. [some level of] hardship, economics vs. environment, saving [energy] as a principle, public regulation vs. individual freedom, and a relaxed homeowner vs. an idealistic home-improver. Realizing these attitudinal dimensions is valuable for determining recommendations and feedback that can be provided to different types of occupants to have effective influence on their behavior. For example, knowing one consumer values profit over environment can help adjusting recommendations so that the user is encouraged to shift consumption in order to save money. Survey can be conducted to collect data on user attitude. In HEM display, a set of simple yes or no questions can be implemented and asked to adjust set of recommendations given accordingly.

The model presented in Figure 1.5-2 shows an overview of relationship between different elements and dimensions related to energy consumption. Based on this model, there are several dimensions that affect energy use. One factor that is controllable by training and education through a CASHEM device is 'attitude', which affects both living standard (i.e., lifestyle) and energy consumption behavior (Figure 1.5-2). This model shows how 'attitude' is affected by public measure for energy conservation, demographics, and standard of living.

One element that is missing in this model is occupants' 'status' which affects number of occupants in the house and is a great determinant of appliance operation schedules. This can be used to derive appliance operation schedules that can be used in real-time energy modeling and simulation as well as recommendations provided. 


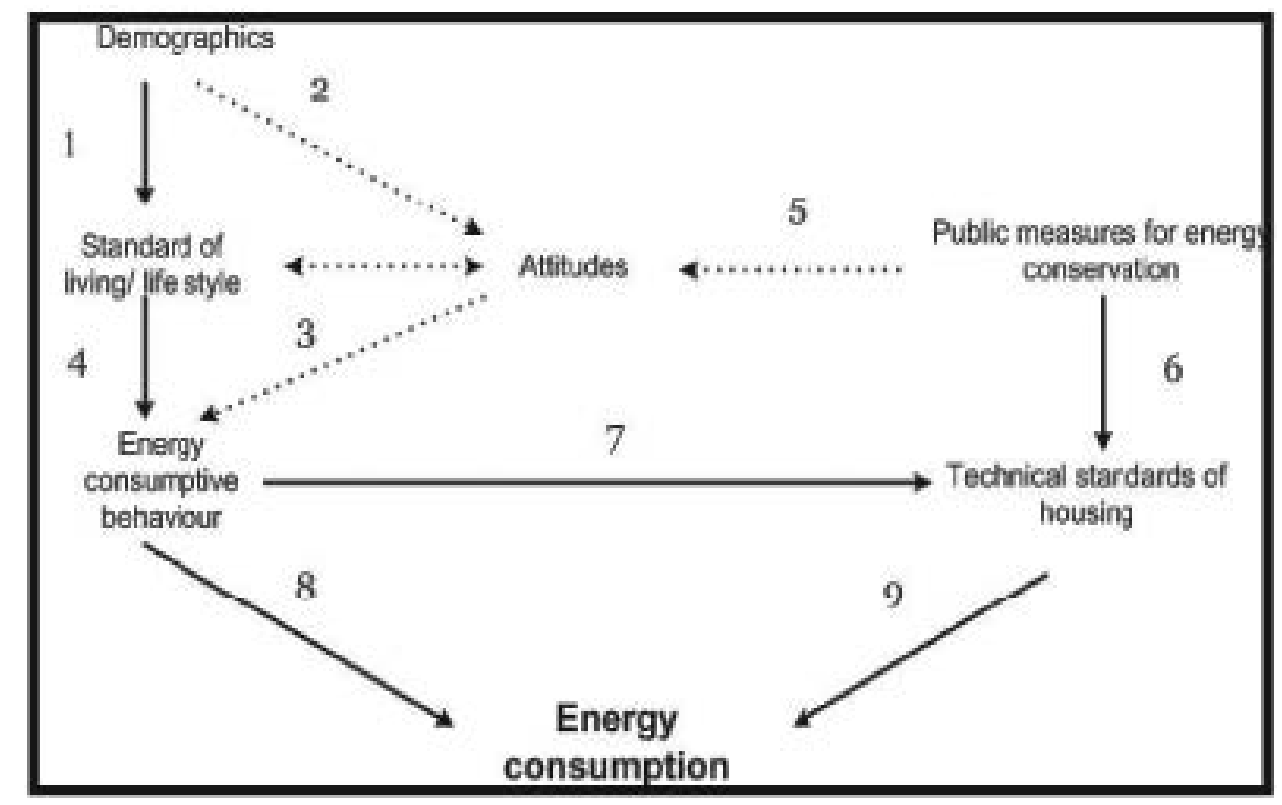

Figure 1.5-2. Model of players in energy consumption based on Aune (1998) found in Naesje et al. (2005)

Many studies use number of bedrooms to determine the number of occupants. Although number of bedrooms can also be used in this case to determine the number of electrical loads, knowing occupant's status would be a better determinant of appliance operation schedule because for example four adults living in a house may need different schedule from two adults and two children living in a household.

Classification of occupants' status has been underestimated in research related to feedback programs. Data collected about status of occupants is however commonly missing and even U.S. Census Bureau does not have data about details of 'who' occupies single-family homes in the U.S. Figure 1.5-3 shows a proposed classification for single-family housing occupants. This classification is based on knowledge collected from several reports and articles available on the internet as well as data on population of general households, families, and group quarters available from the U.S. Census Bureau ${ }^{1}$.

Another important factor in deriving effective recommendations is user's 'preference'. Preference is defined by Merriam-Webster Online dictionary as:

1. $a$ : the act of preferring : the state of being preferred $b$ : the power or opportunity of choosing

2. the act, fact, or principle of giving advantages to some over others

As noted above, in the case of HEM, giving the occupant the power to choose is not totally in line with goals of energy conservation. Therefore, recommendations should be given in a way that can optimize user satisfaction while saving energy/electricity. Satisfying user's preference can also be achieved by CASHEM through utilizing on-site power generations and storage. Managing power generated on-site in addition to appliance operation management is the strength of CASHEM and where this work mainly distinguishes from other feedback program research done historically.

\footnotetext{
${ }^{1}$ http://www.census.gov/compendia/statab/cats/population/households families group quarters.html.
} 

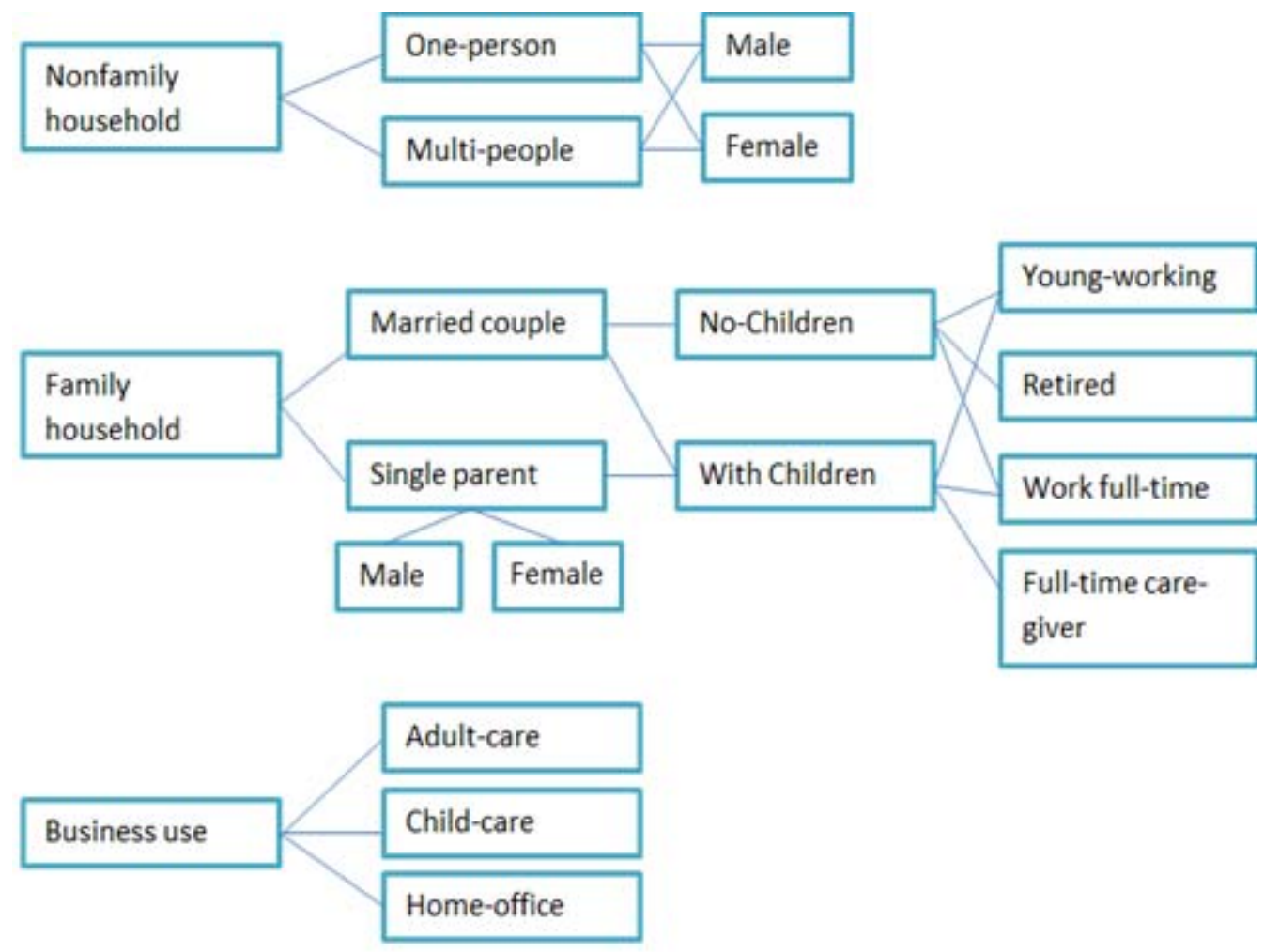

Figure 1.5-3. Proposed user status classification

\subsubsection{Frequency of Use of Appliances Based on Number of Occupants}

The DOE has collected detailed data about number of appliances in the United States, age of appliances, number of household members, and so on. Although there is no information about the structure of family (i.e., status of occupants) as well as behavior, data related to frequency of each appliance use can still be useful to derive more effective recommendations. This is because they reflect and reveal some information about preference of appliance use depending on number of household members. For example, these data can be used to decide how many loads of dishwasher operation should be expected if there are four people in the household. Data available from Residential Energy Consumption Survey (RECS) ${ }^{1}$ are tabulated and shown in Figure 1.5-3 to Figure 1.5-11 below for electric stoves, dishwashers, clothes washers and clothes dryers (numbers in the figures are in millions).

\subsubsection{Energy Use Profiles}

Figure 1.5-12 to Figure 1.5-19 show an average of total power consumption in a typical week and weekend in each season over a 24-hour period. These are based on metered data available from FSEC. Data presented are from five different homes participating in FSEC building science program study. These homes were described in Task 1.1 of this project ${ }^{2}$. Table 1.5-2 below summarizes description of homes selected here. It should be noted that some of these are zero energy homes.

\footnotetext{
${ }^{1}$ Residential Energy Consumption Survey (RECS) http://www.eia.gov/consumption/residential/data/2009/

${ }^{2}$ For more information refer to the spreadsheet included in the Task 1.1 deliverable.
} 


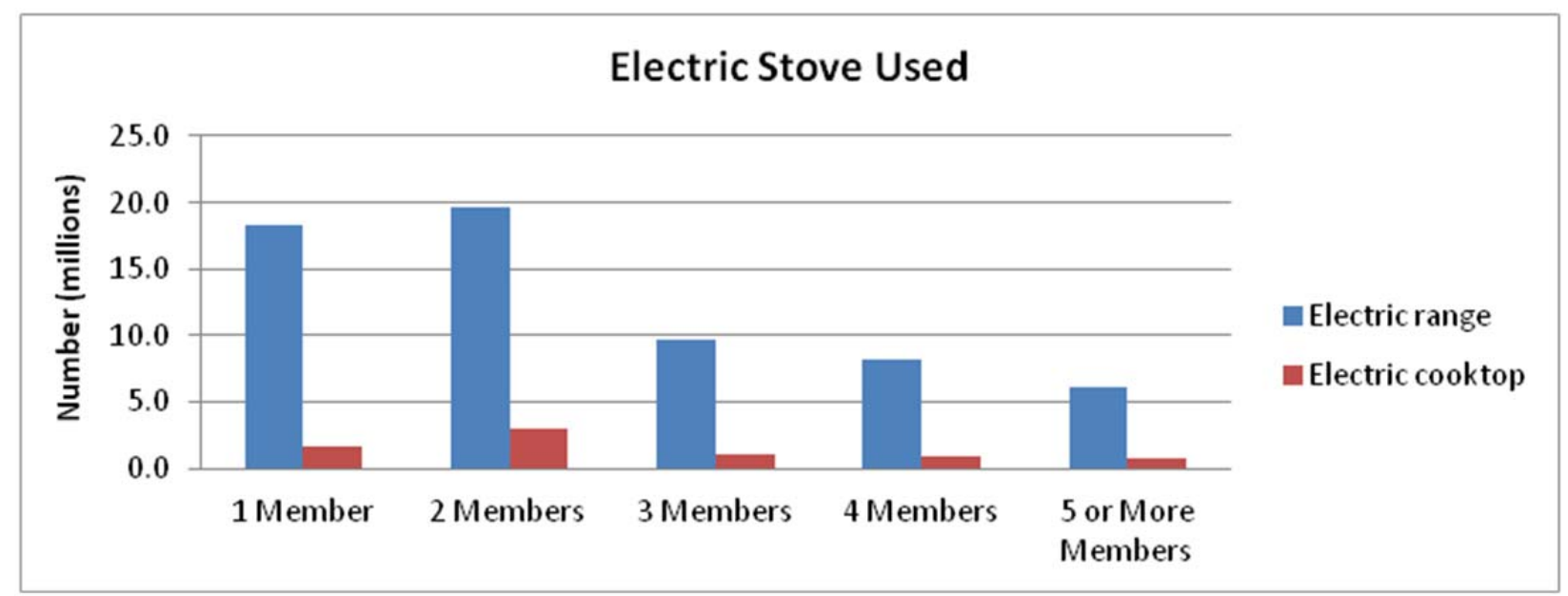

Figure 1.5-4. Number of electric stoves based on number of household members

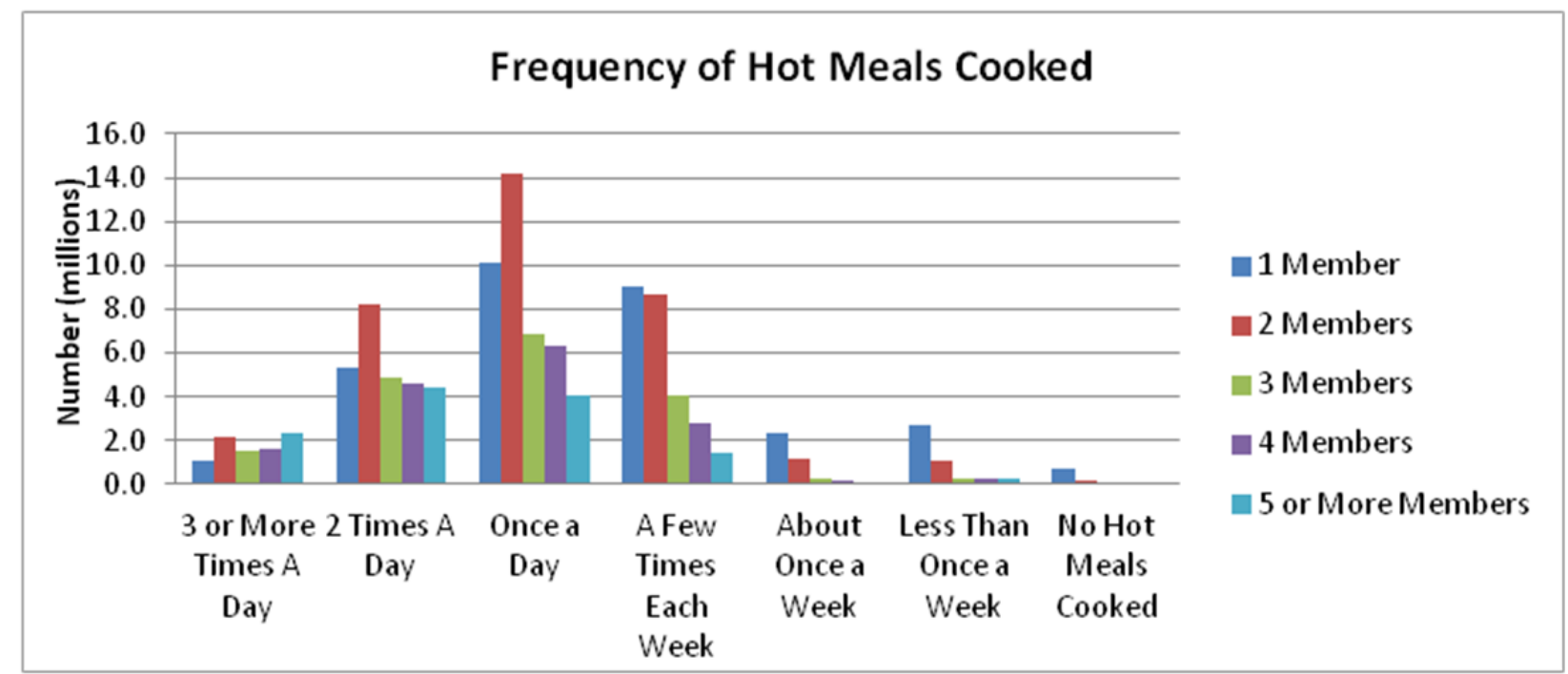

Figure 1.5-5. Frequency of cooking based on number of household members

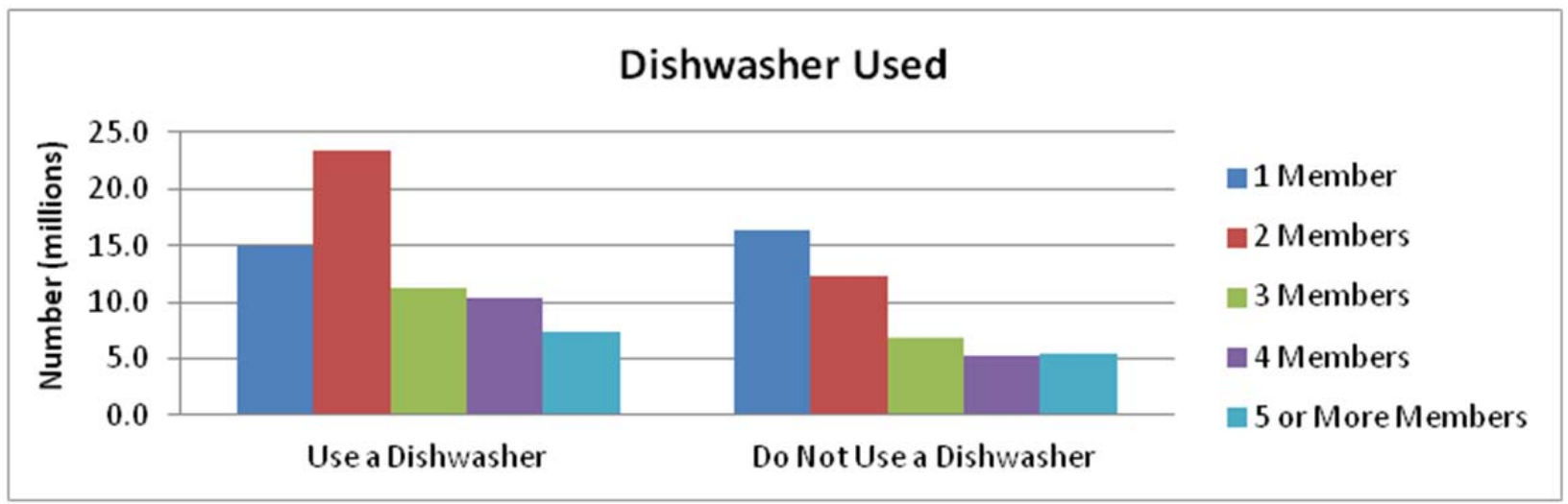

Figure 1.5-6. Number of homes that do use or not use a dishwasher based on number of household members 


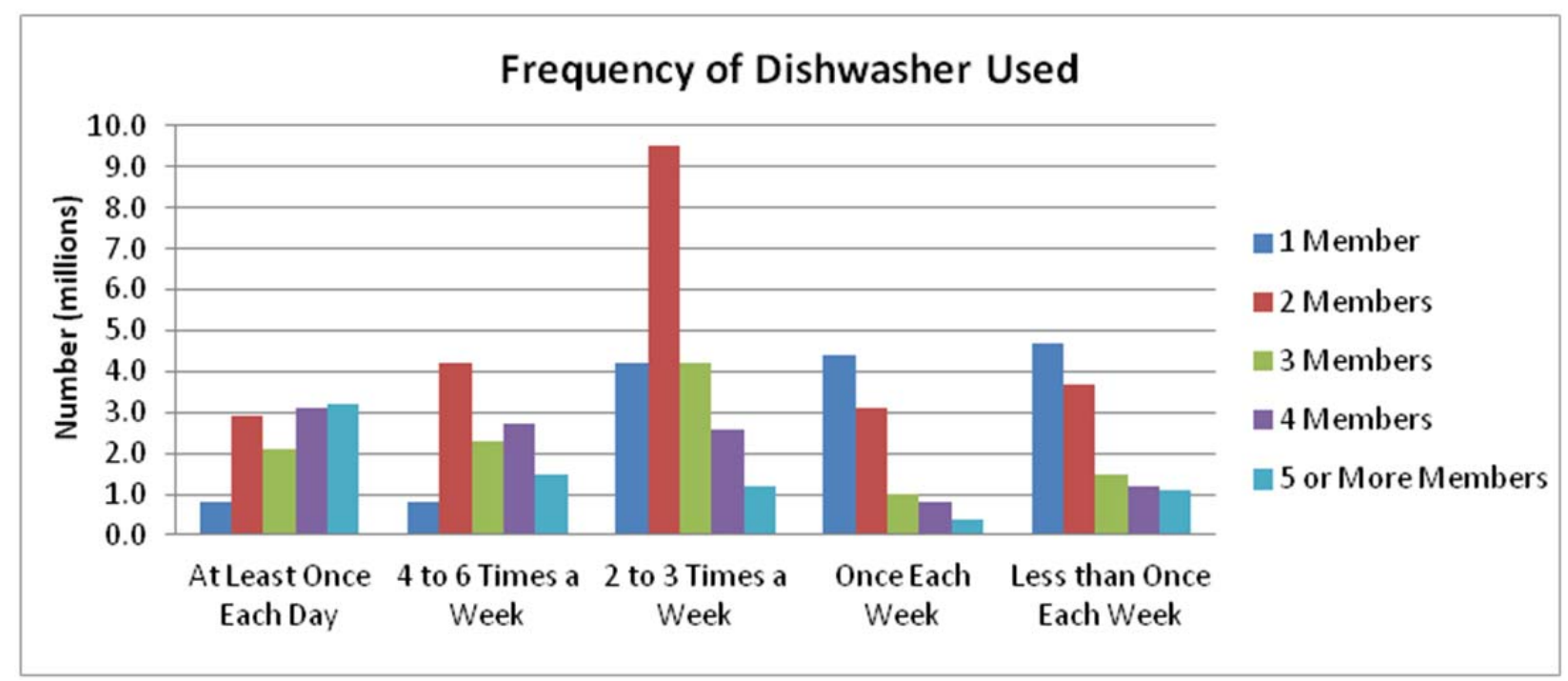

Figure 1.5-7. Frequency of use of dishwasher based on number of household members

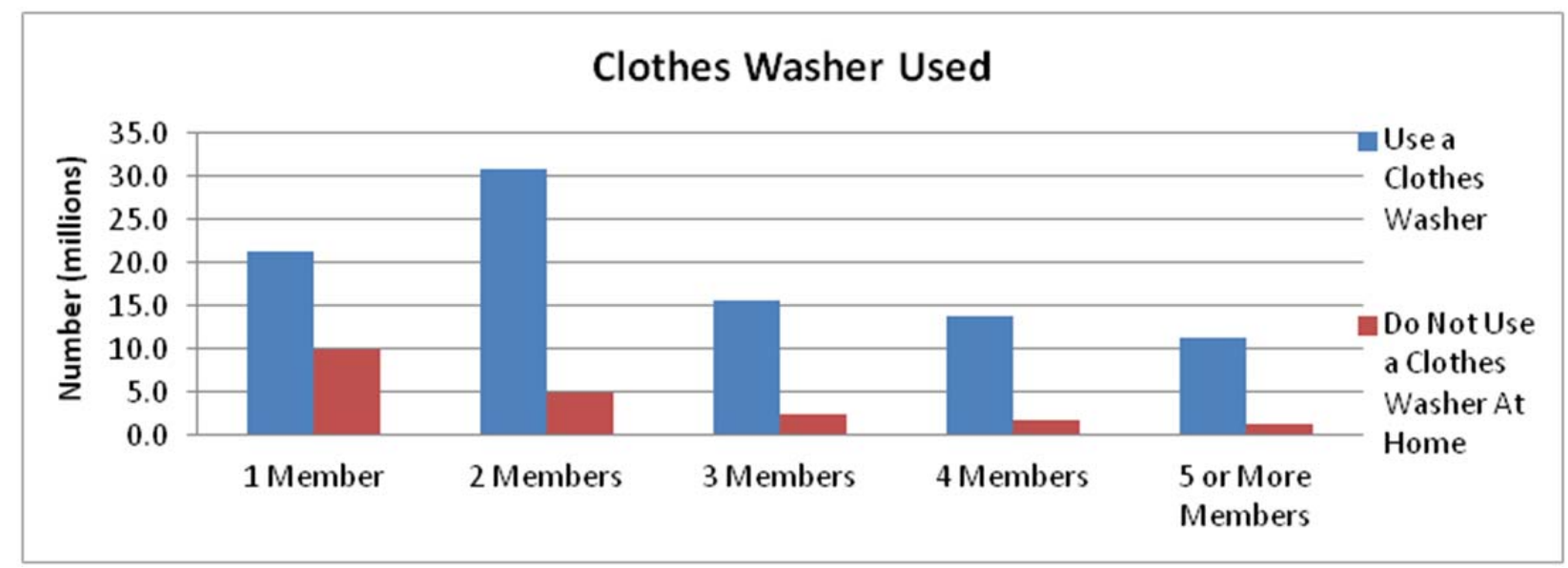

Figure 1.5-8. Number of clothes washers used based on number of household members

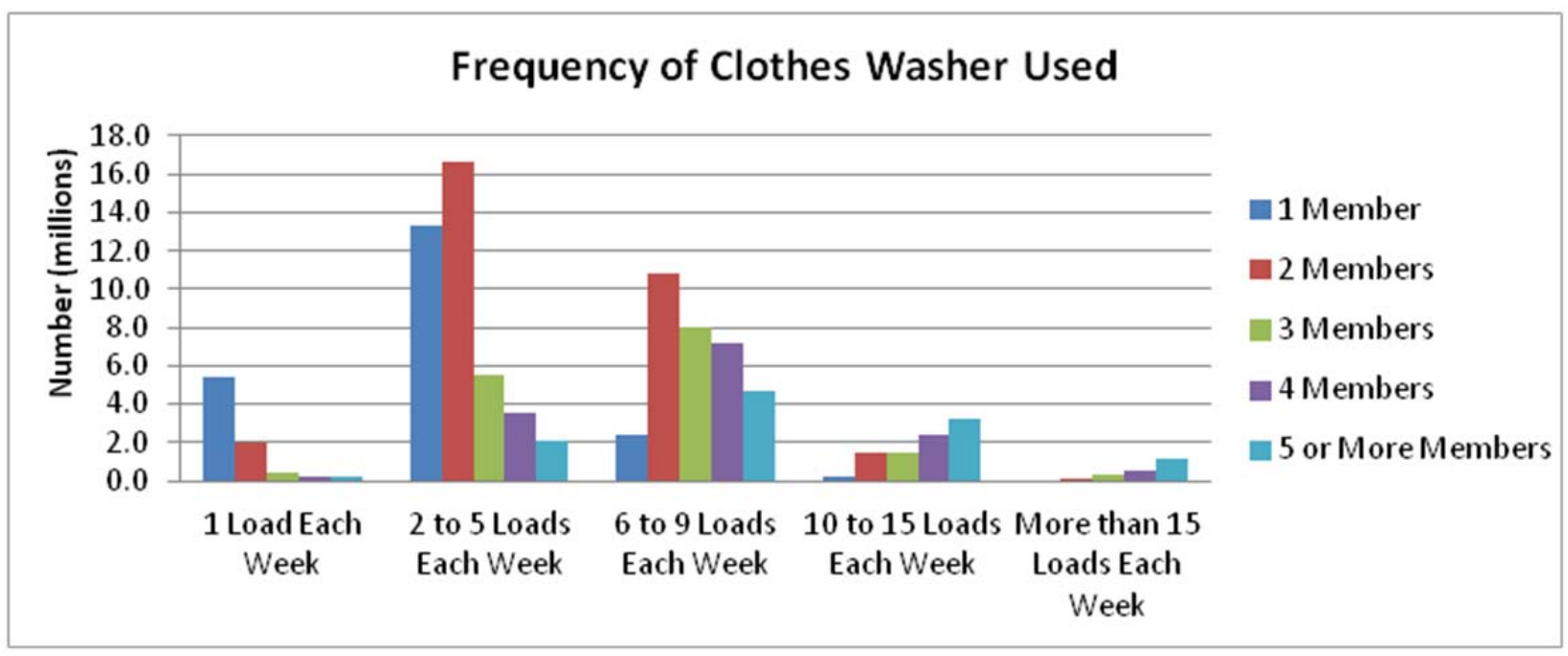

Figure 1.5-9. Frequency of use of clothes washer based on number of household members 


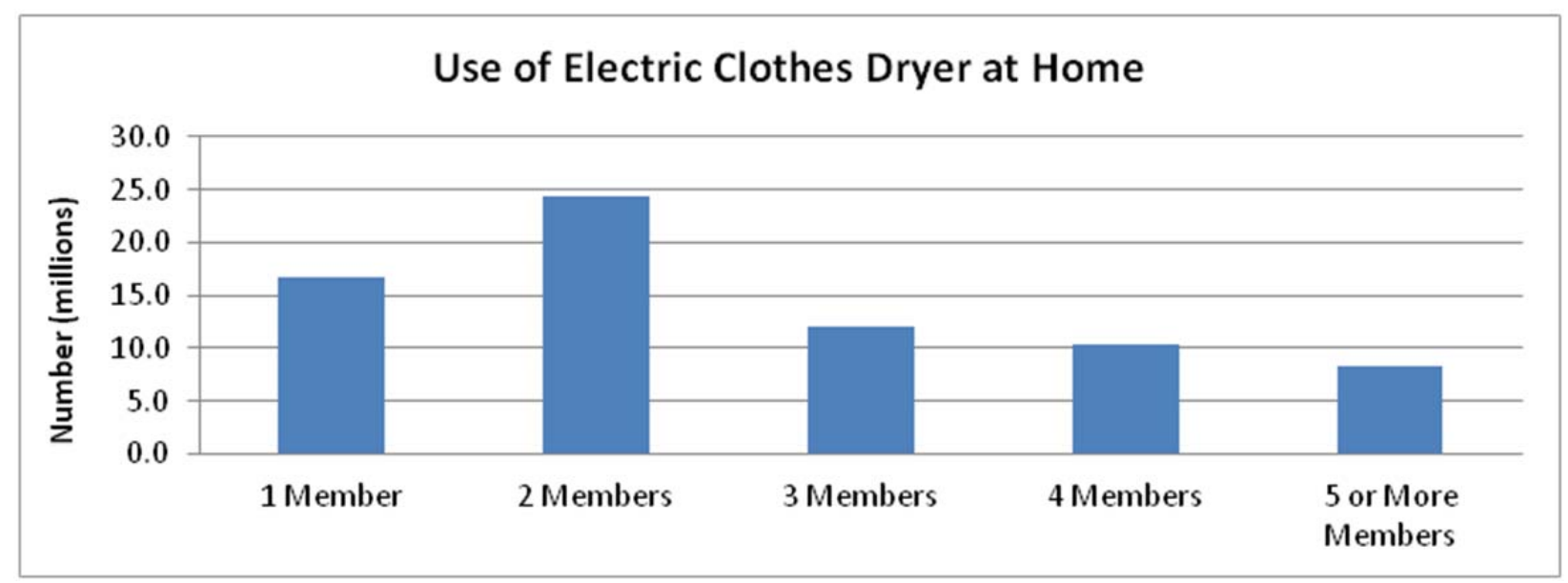

Figure 1.5-10. Number of electric clothes dryers used at home based on number of household members

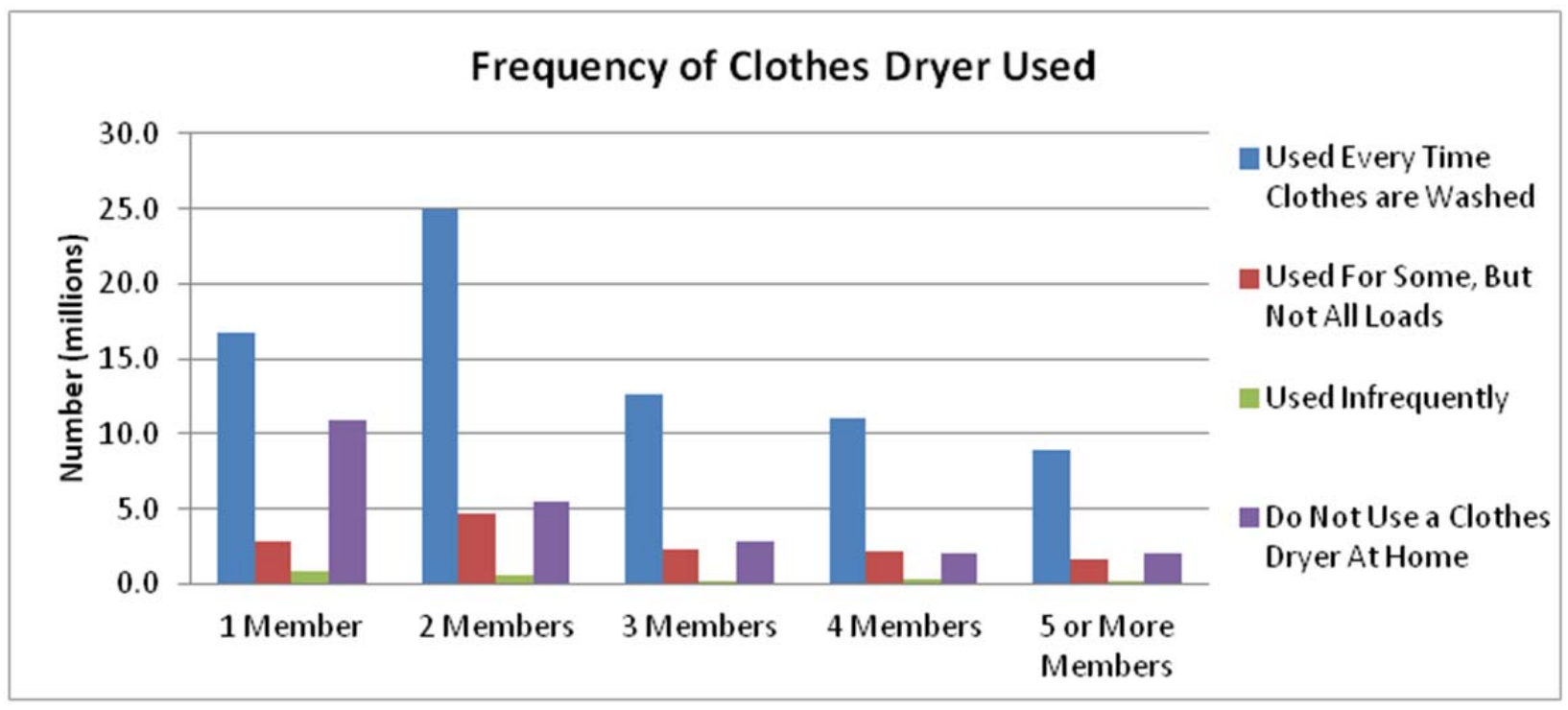

Figure 1.5-11. Frequency of use of clothes dryer based on number of household members

Table 1.5-2. Description of the homes participating in the FSEC metering study.

\begin{tabular}{|l|l|}
\hline Name & \multicolumn{1}{c|}{ Description } \\
\hline NZG & $\begin{array}{l}\text { Near Zero Energy Home: Gainesville, FL. } \\
\text { Occupied by a family of 2. It is a 1,772 } \mathrm{ft} 2 \text {, single story, three bedroom/two bath home with a HERS }\end{array}$ \\
\hline ZEG & $\begin{array}{l}\text { Planned Zero Energy Home: Gainesville, } \mathrm{FL} \\
\text { It is a single story three bedroom/two bath home with } 1,519 \mathrm{ft}^{2} \text { of living space and a preliminary HERS rating of } 16 .\end{array}$ \\
\hline DPR & $\begin{array}{l}\text { A deep retrofit, zero energy home located in Cocoa Beach, Florida. } \\
\text { Originally built in 1957, it is a 2,000 } \mathrm{ft}^{2} \text { four bedroom/two bath home with an office space and Florida room. It is } \\
\text { occupied by two adults and two teenagers. }\end{array}$ \\
\hline TW1 & $\begin{array}{l}\text { Florida's first production built, net zero energy home. Located in Gainesville, Florida. } \\
\text { It is a single story three bedroom + office/ two and half bath home with 2,248 } \mathrm{ft}^{2} \text { and a HERS rating of -2. }\end{array}$ \\
\hline TW2 & $\begin{array}{l}\text { Net zero energy home located in Newberry, Florida. It is a single story three bedroom / two bath home with 1,546 } \\
\mathrm{ft}^{2} \text { and a HERS rating of 1. }\end{array}$ \\
\hline (a) Home Energy Rating System (HERS) program: http://www.energy.ca.gov/HERS/
\end{tabular}




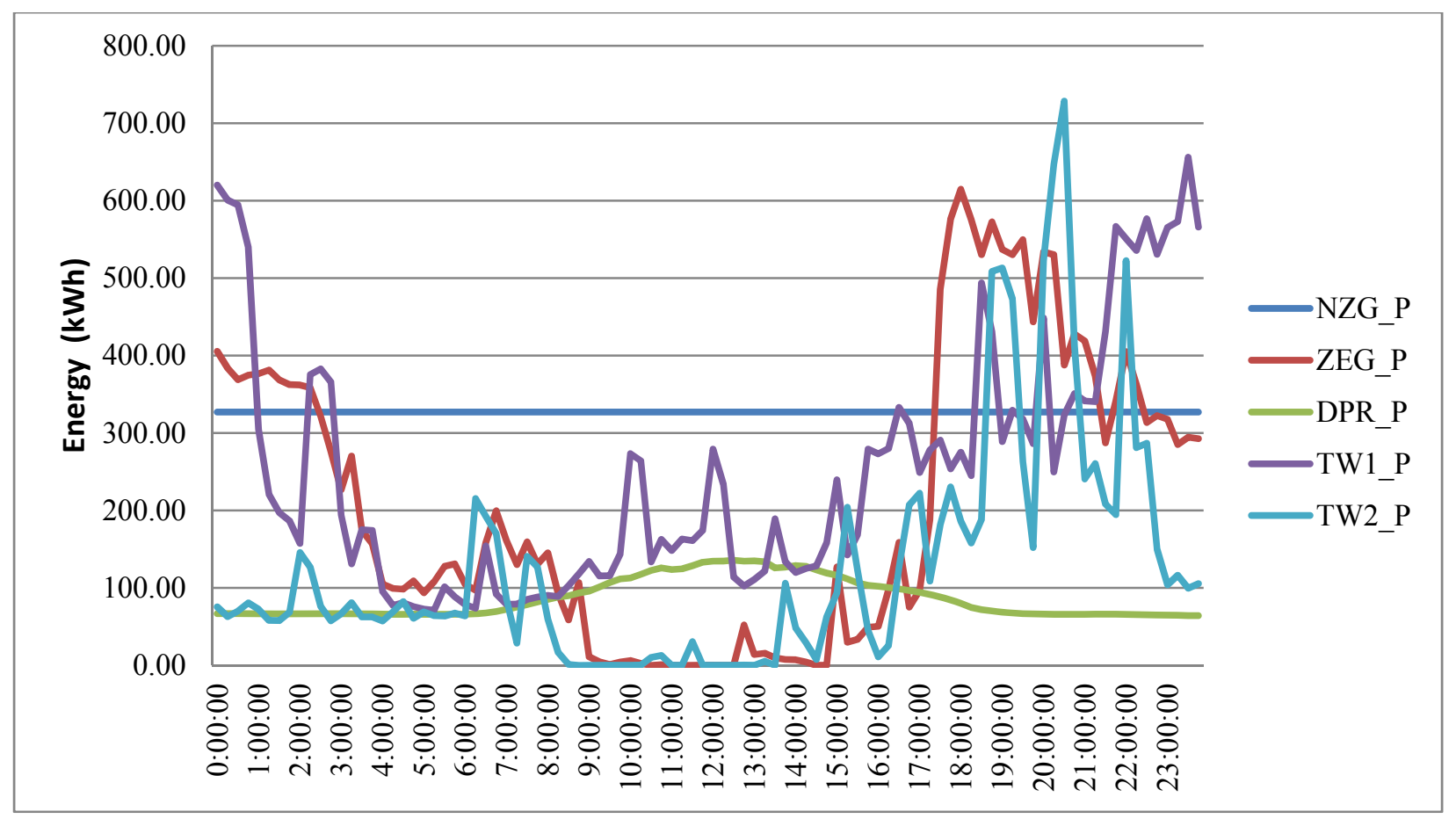

Figure 1.5-12. Typical weekday (spring)

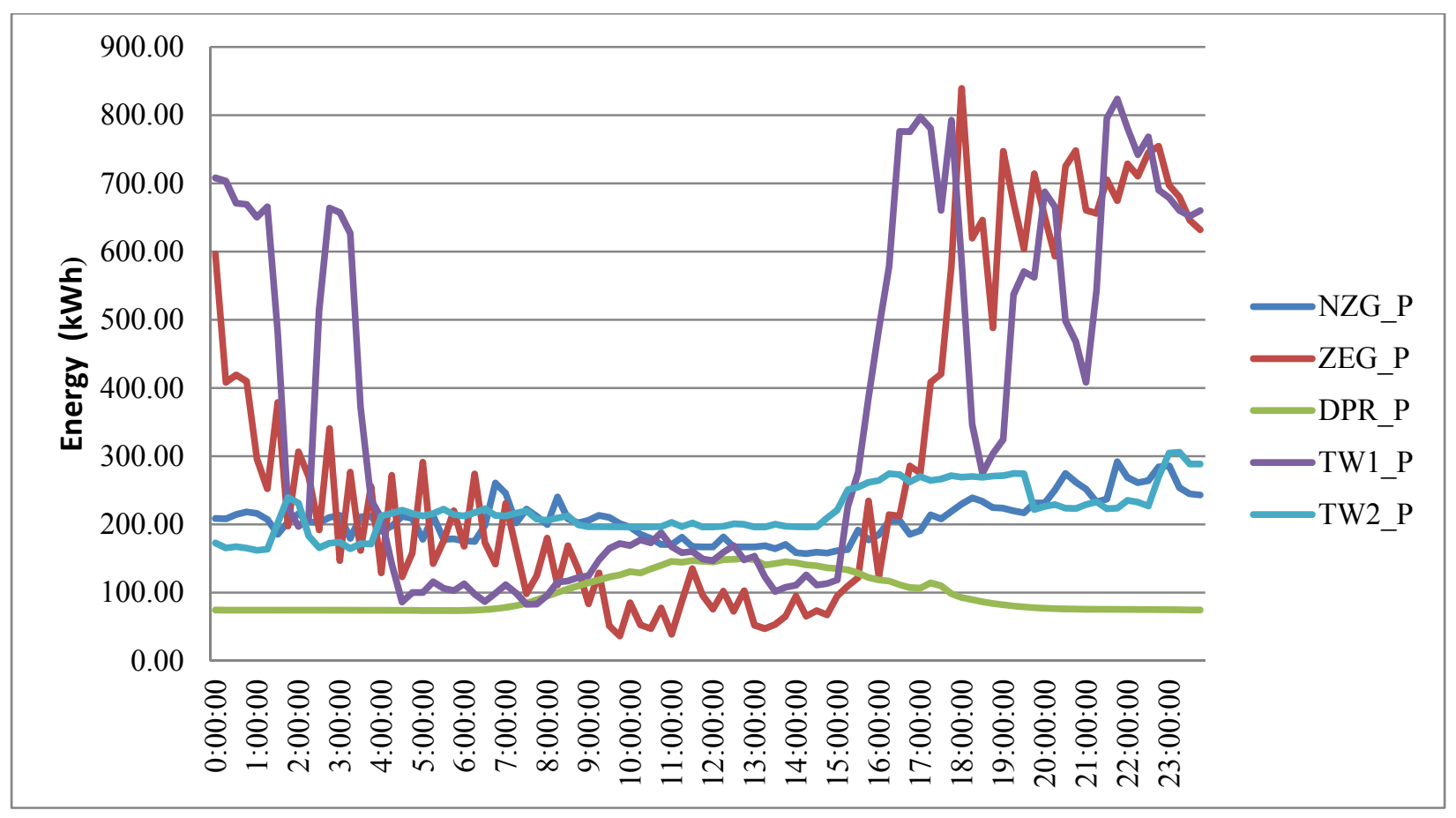

Figure 1.5-13. Typical weekday (summer) 


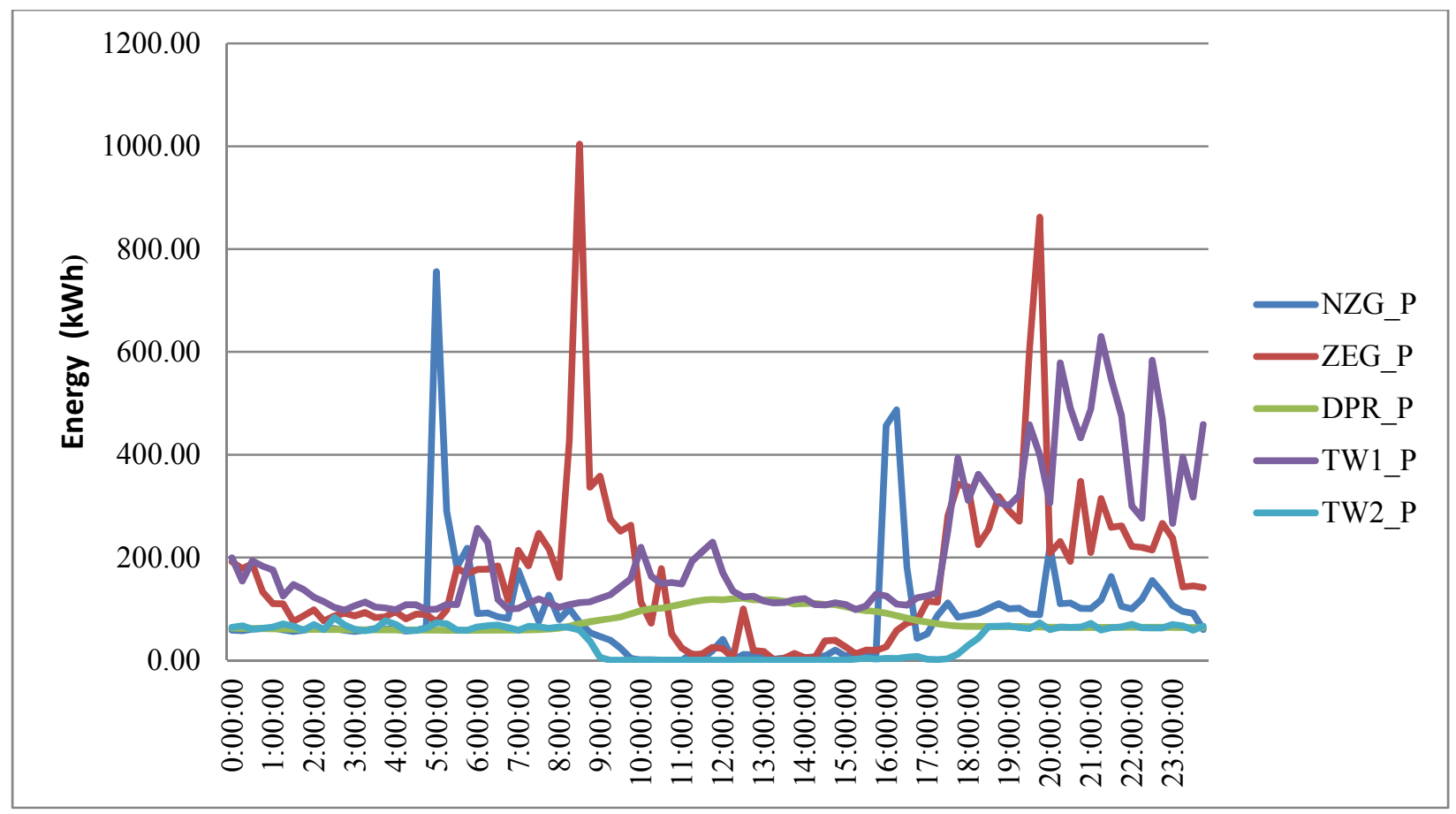

Figure 1.5-14. Typical weekday (fall)

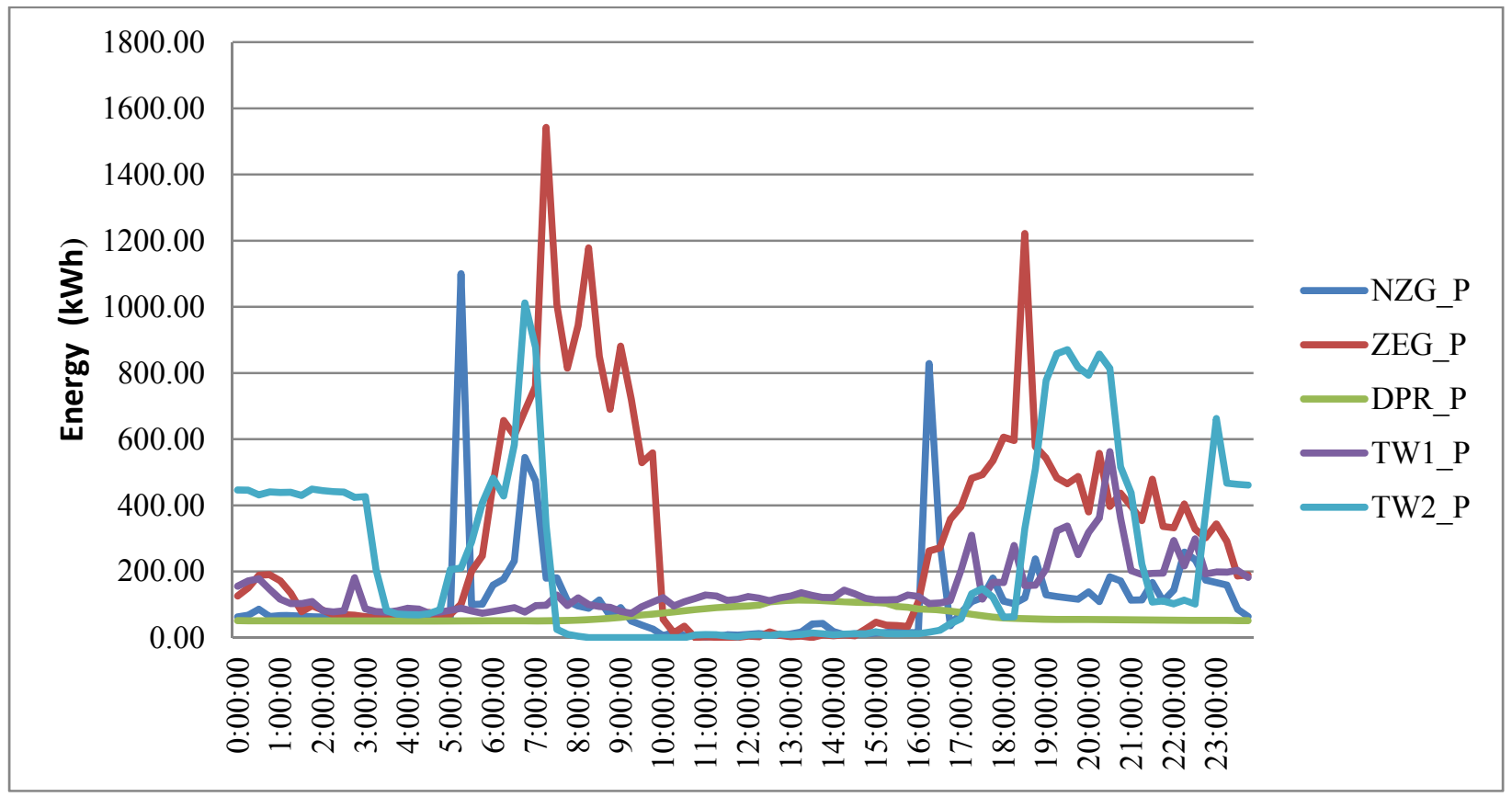

Figure 1.5-15. Typical weekday (winter) 


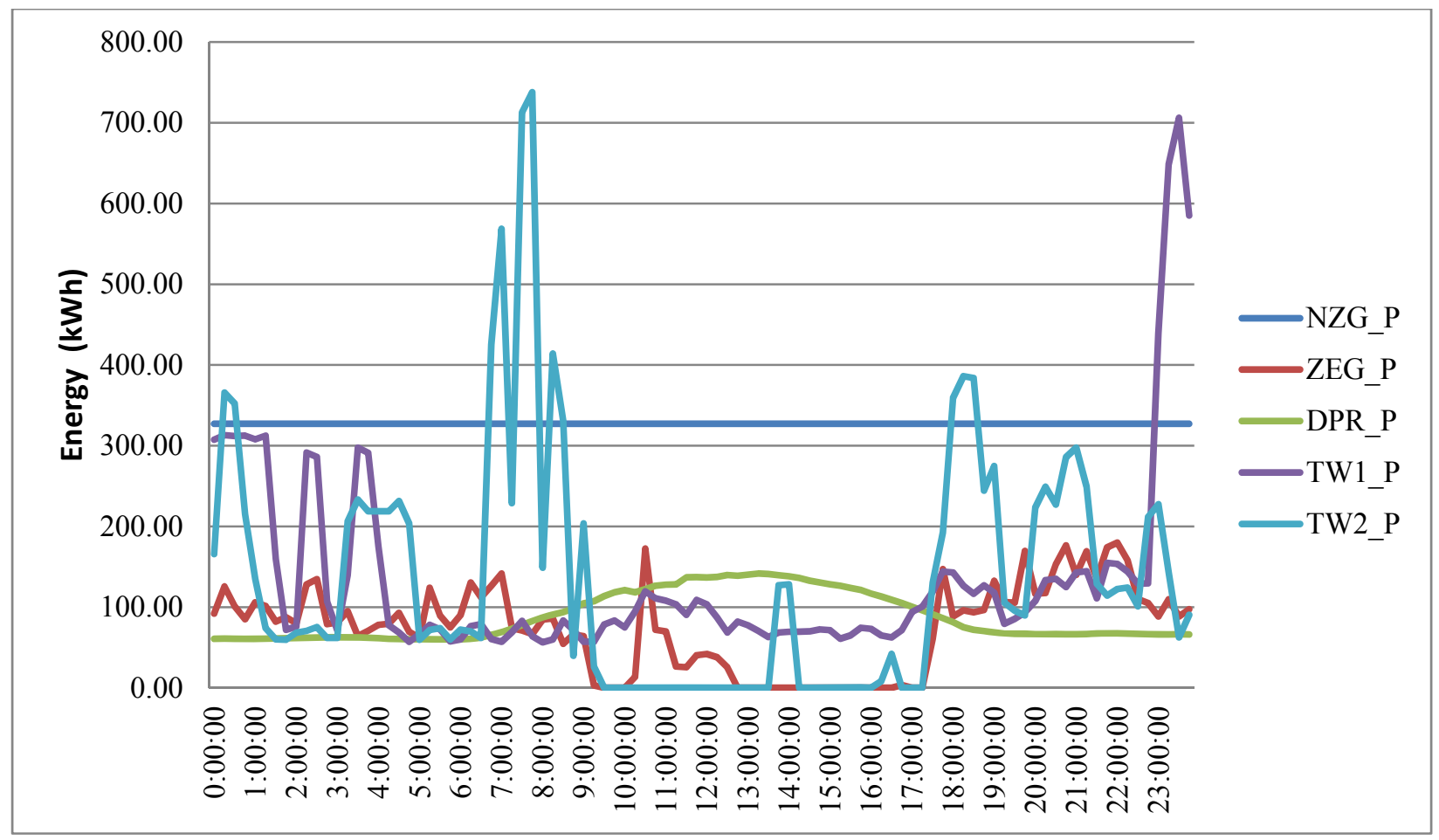

Figure 1.5-16. Typical weekend (spring)

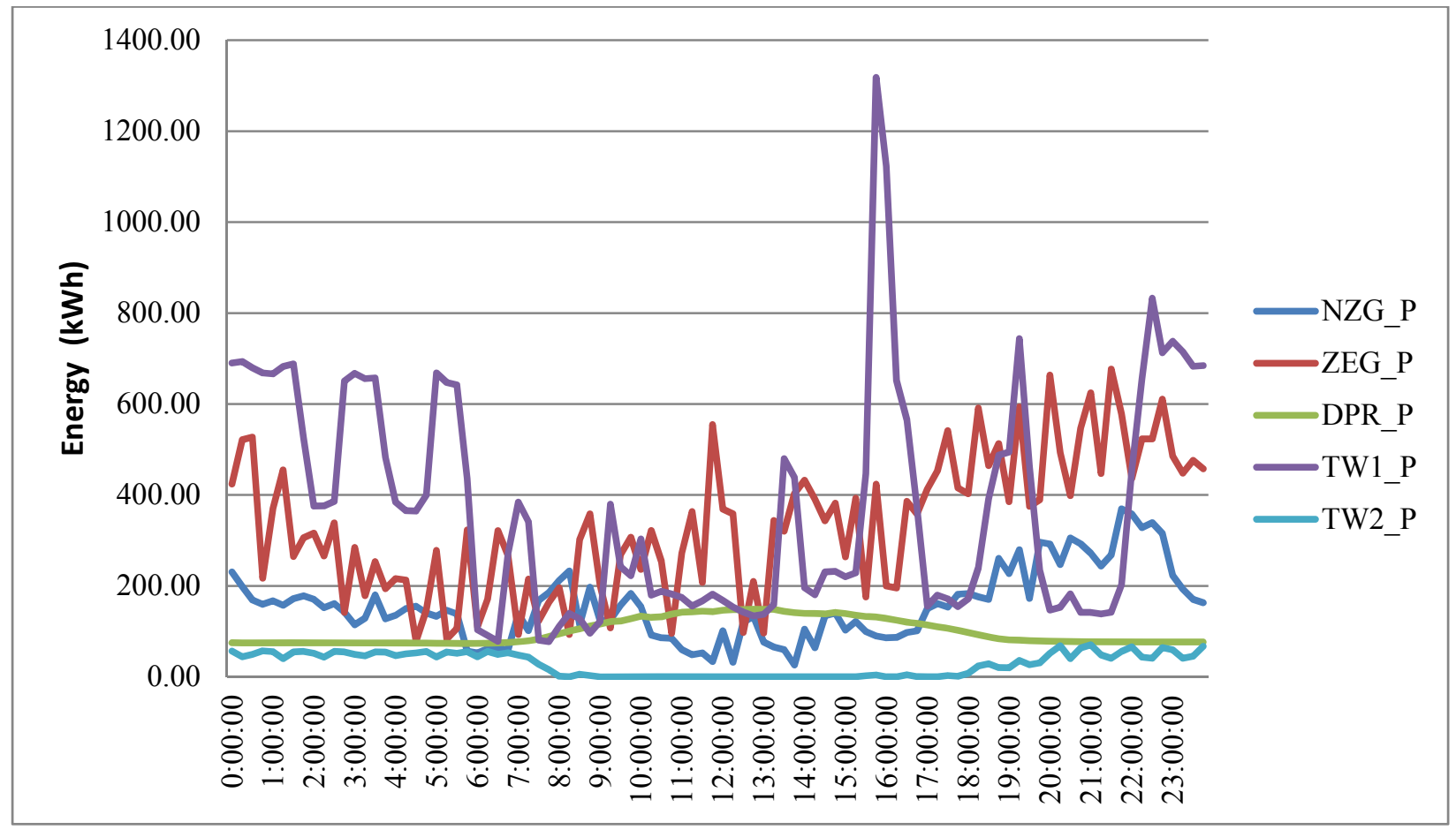

Figure 1.5-17. Typical weekend (summer) 


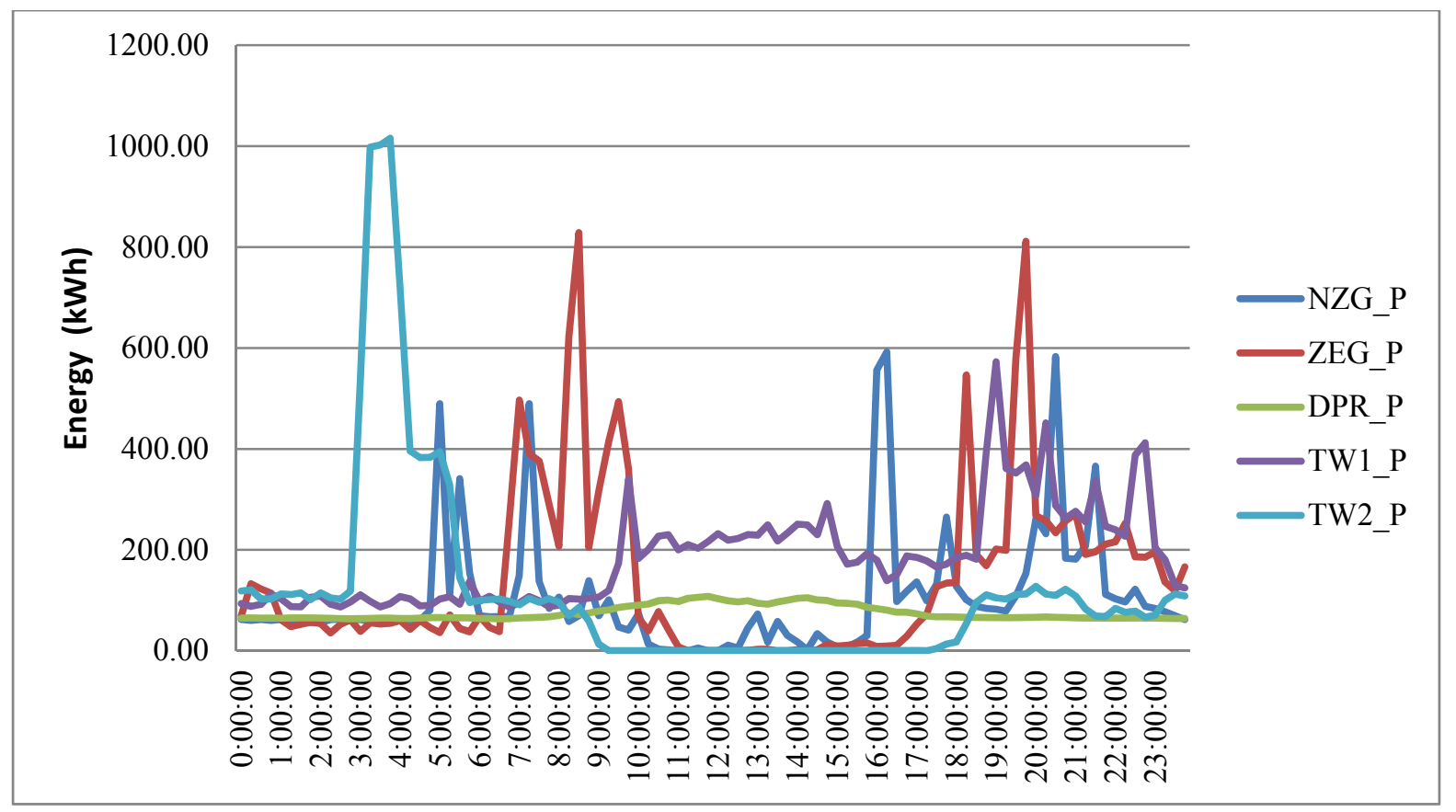

Figure 1.5-18. Typical weekend (fall)

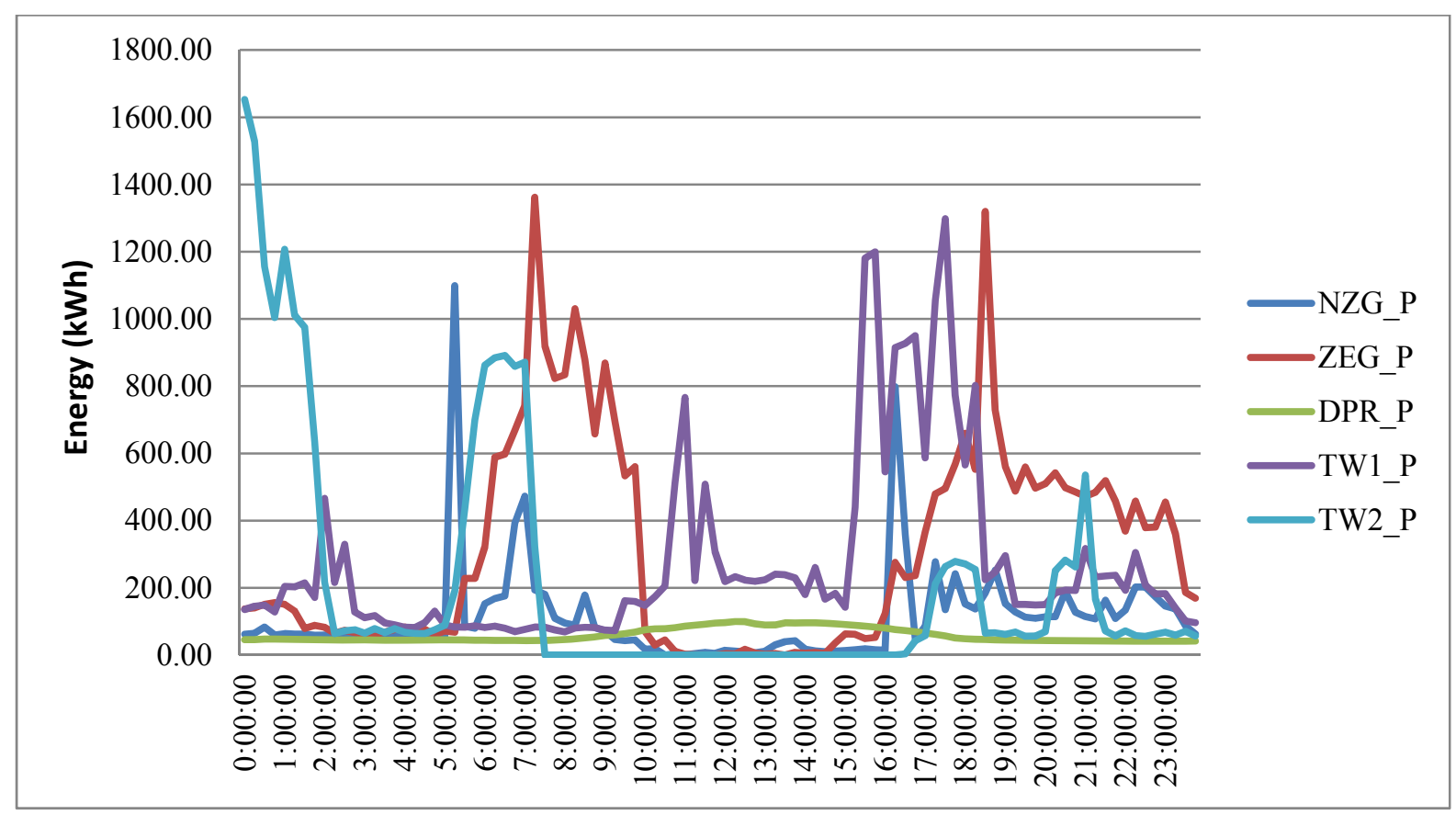

Figure 1.5-19. Typical weekend (winter)

These measured data clearly show that different users have different energy use profiles. Drawing user type behavior or characteristics based on historical energy profile requires data regarding user's status and attitude. Generally, such data are not collected consistently along with metered data and therefore not available. 


\subsubsection{Average Energy Use Profile and Schedules Based on EnergyPlus and ELCAP $^{1}$}

Appliance schedules used in EnergyPlus residential prototype models are based on several studies including load shapes from the End-Use Load and Consumer Assessment Program (ELCAP) metered data and represent an average usage patterns for different appliances.

While the confidence in ELCAP as a data source has waned since the end-use metering study was performed in the $1980 \mathrm{~s}$, most other studies are either unavailable or too small for generalization. It is likely that for major appliances, while efficiencies might have increased, usage patterns may be similar. In the EnergyPlus models, ELCAP load shapes are used to schedule appliance usage, but the appliance energy consumption is modeled based on current updated information.

These detailed residential models have been developed to represent residential buildings in terms of envelope, systems, operation schedule and plug load as closely as possible to reality. Therefore, they provide a good representation of household energy consumption profile that can be used for different studies related to building energy from design stage to operation. These modeling and simulation efforts to predict energy profile of buildings can be used to make informed decisions regarding design of residential buildings, selection of heating and cooling systems, choice of on-site power generation and also operation of the building.

Figure 1.5-20 to Figure 1.5-25 below show schedules used in EnergyPlus residential prototype building models as well as ELCAP data which are an aggregated average home energy metered data over a period of 24-hours for a large number of homes. These data can be used to extract peak hours and set recommendations in a manner that shifts load outside hours of high energy demand. Another related issue is the rebound effect from load reduction. Therefore, while shifting load is critical, rebound effect should also be taken into consideration.

\footnotetext{
${ }^{1}$ The Pacific Northwest End Use Load and Conservation Assessment Program residential end-use metering study conducted from 1986 to 1996. ELCAP data are available on the ELCAP on-line data base at http://elcap.cadmusweb.com/
} 


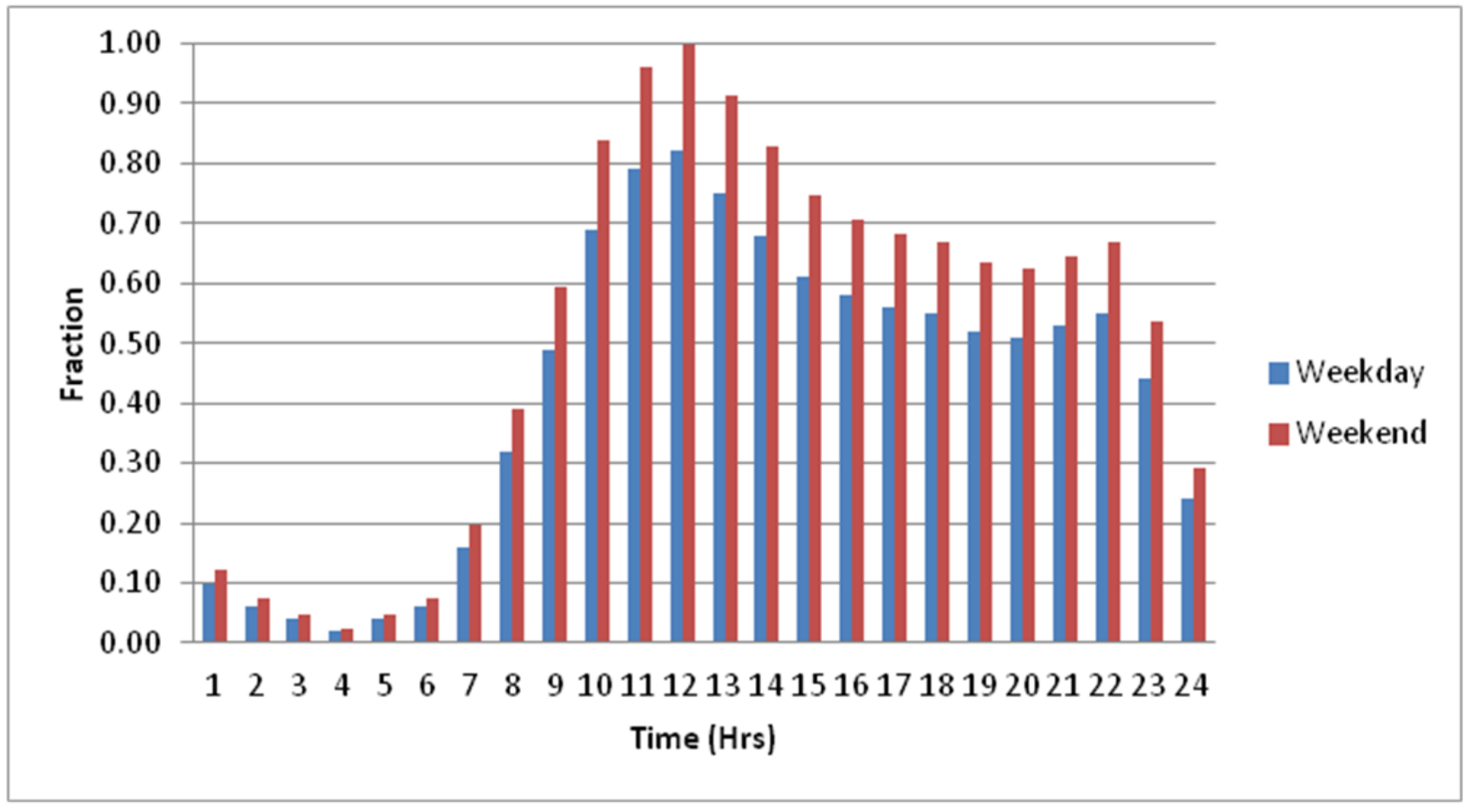

Figure 1.5-20. Clothes dryer schedule modeled in EnergyPlus

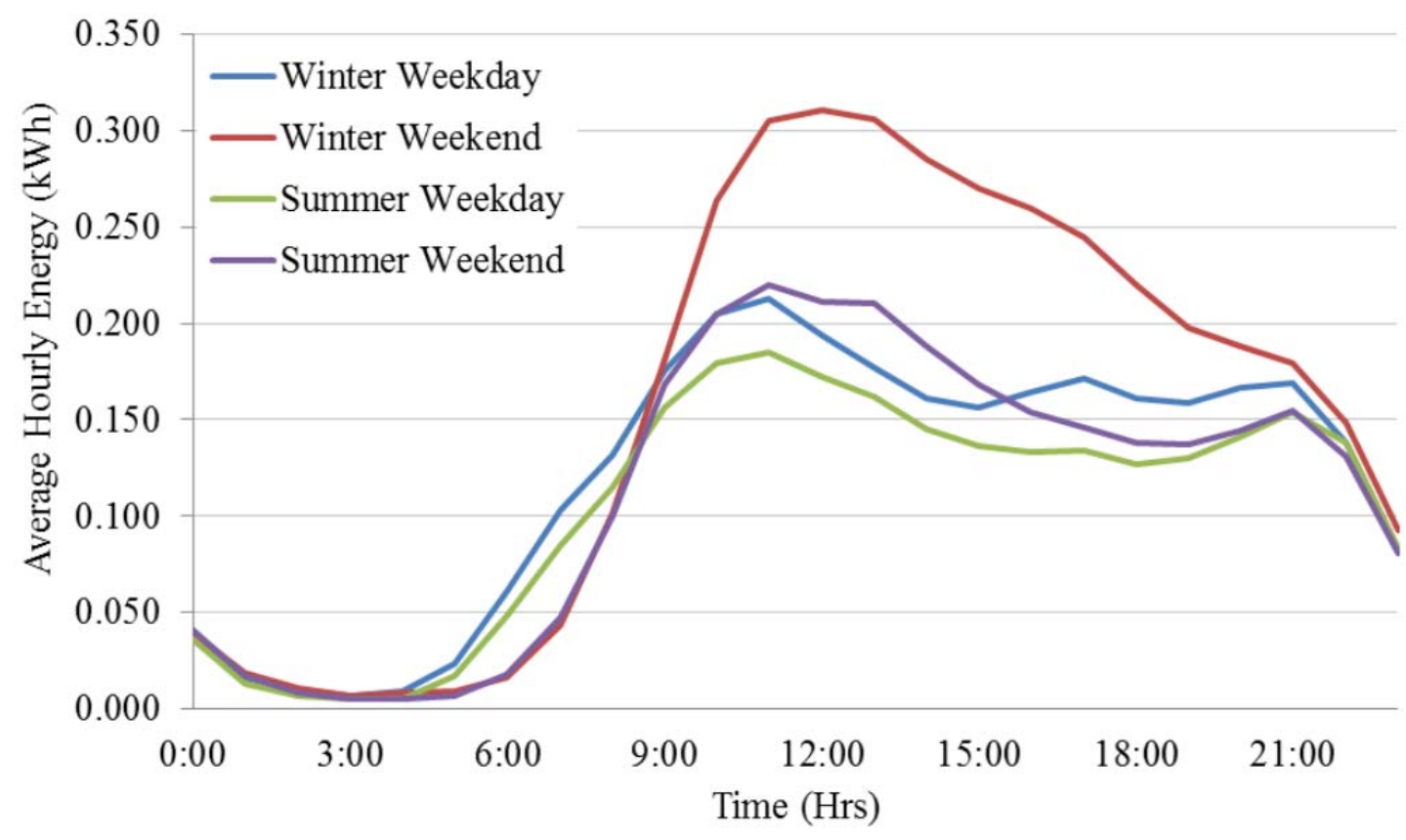

Figure 1.5-21. Clothes dryer load profile from ELCAP data 


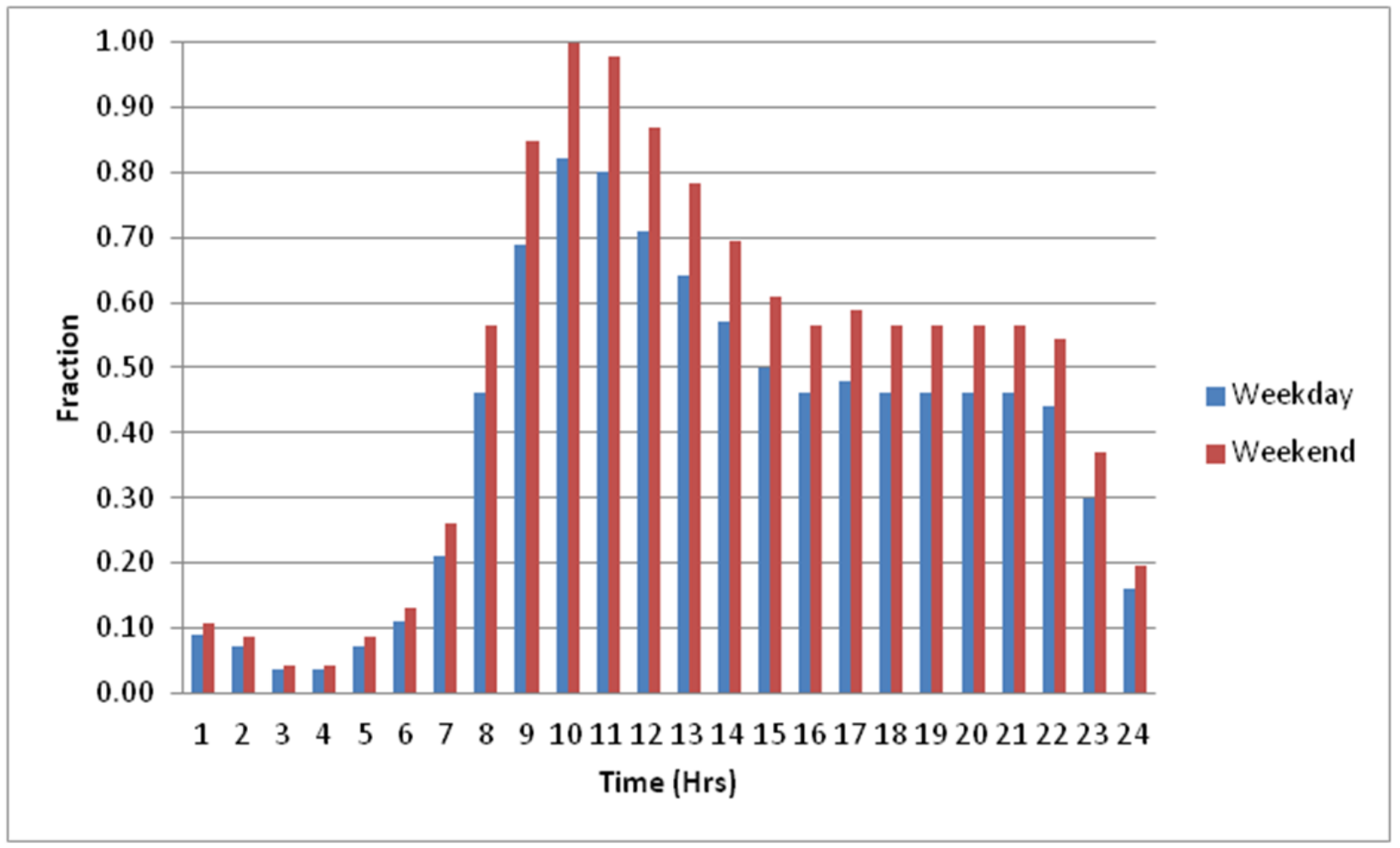

Figure 1.5-22. Clothes washer schedule modeled in EnergyPlus

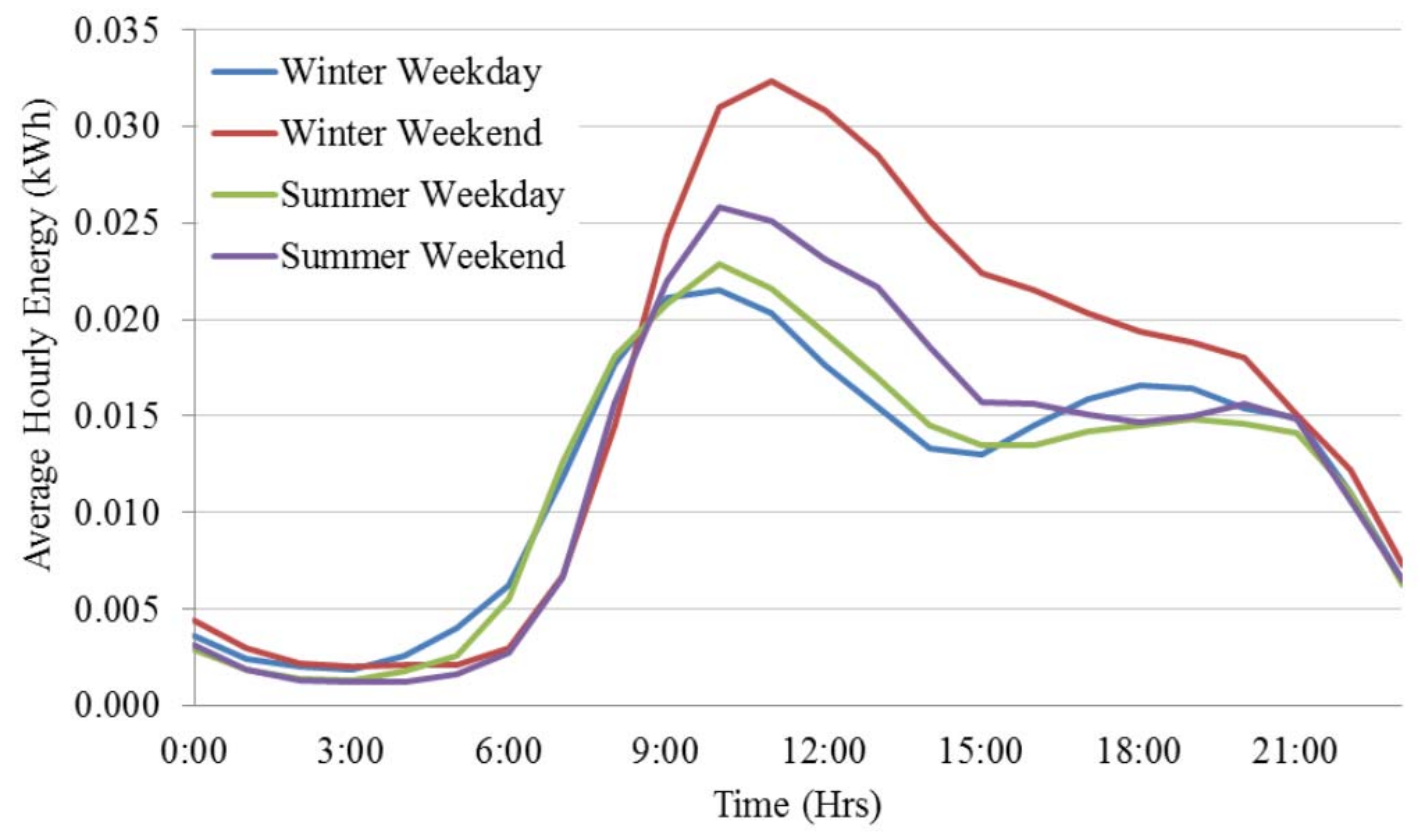

Figure 1.5-23. Clothes washer load profile from ELCAP data 


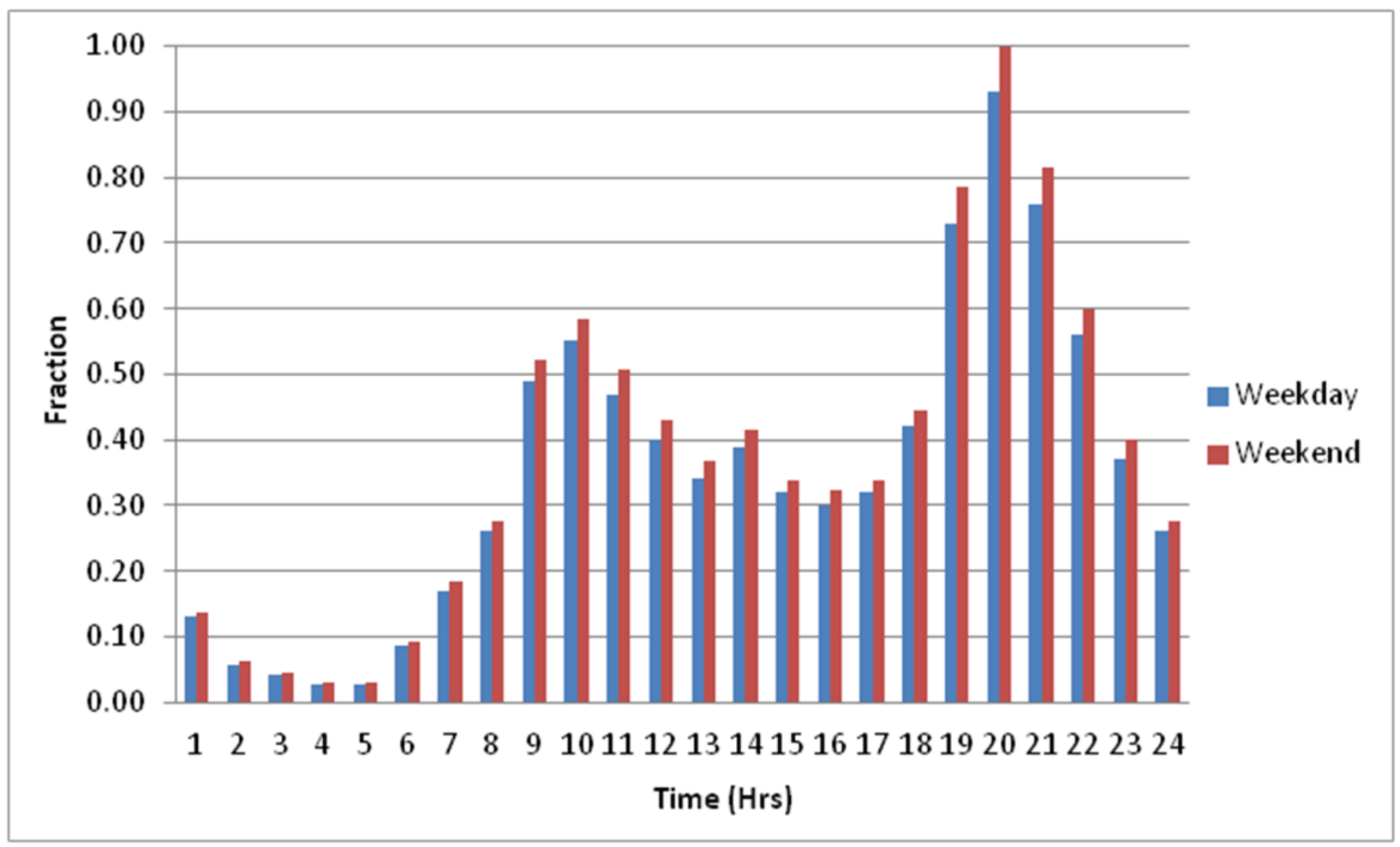

Figure 1.5-24. Dishwasher schedule modeled in EnergyPlus

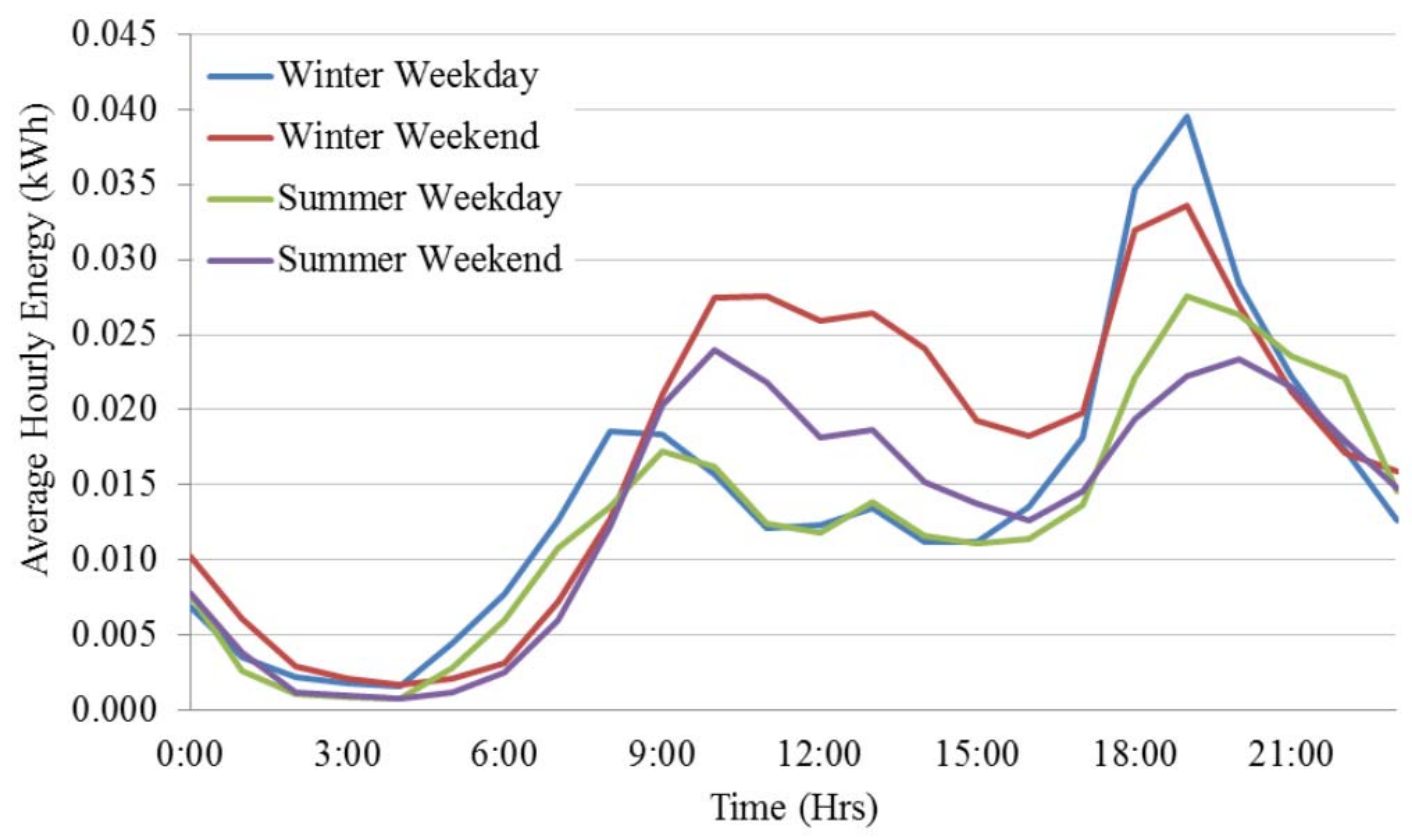

Figure 1.5-25. Dishwasher load profile from ELCAP data 


\subsubsection{Conclusions}

The main objective of this task was to find parameters that can be used to derive the most effective recommendations to be generated by a Context Aware Smart Home Energy Management (CASHEM) device. A literature review was performed to find factors that mainly affect energy consumption of singlefamily detached residential buildings. Based on this review it was found that user's attitude towards energy consumption and their status (which determines factors such as income and household size) have direct influence on how much energy is consumed. In addition to that, results of feedback program studies and research done historically showed that 'social insights' are parameters that play key role in derivation of influential and effective recommendations to reduce energy consumption through real-time feedback programs. Figure 1.5-26 shows how user characterization and preferences can be used to derive effective recommendations. This same approach shown in Figure 1.5-26 can also be taken to generate specific recommendations for display to the homeowner/user.

The shaded box in blue highlights steps of the process covered in this section. Based on literature, a user can be characterized as one who has attitude and status. These are shown in the dashed box in Figure 1.5-26 and their details are listed. Using user's 'attitude' towards energy consumption it is possible to find how flexible the user is in shifting loads and also what appliance modes of operation they are more likely to use. User's 'status' can be used to determine number of loads needed per week as well as schedule that best fits requirements of a household.

Operation modes available in each appliance are another factor that should be considered in developing recommendations. Finally, social insights are another major determinant in making recommendations influential and encouraging for the user to follow. Studies show that by taking advantage of social insights in feedback programs, it is possible to reduce energy consumption by 20 $35 \%$. Therefore, recommendations should not just be informative, but they should also set up achievable energy saving goals, let occupants know what is the 'normal' amount of energy used by peer groups, make them committed to energy saving plans, and create a more competitive environment that encourages them to save energy. 


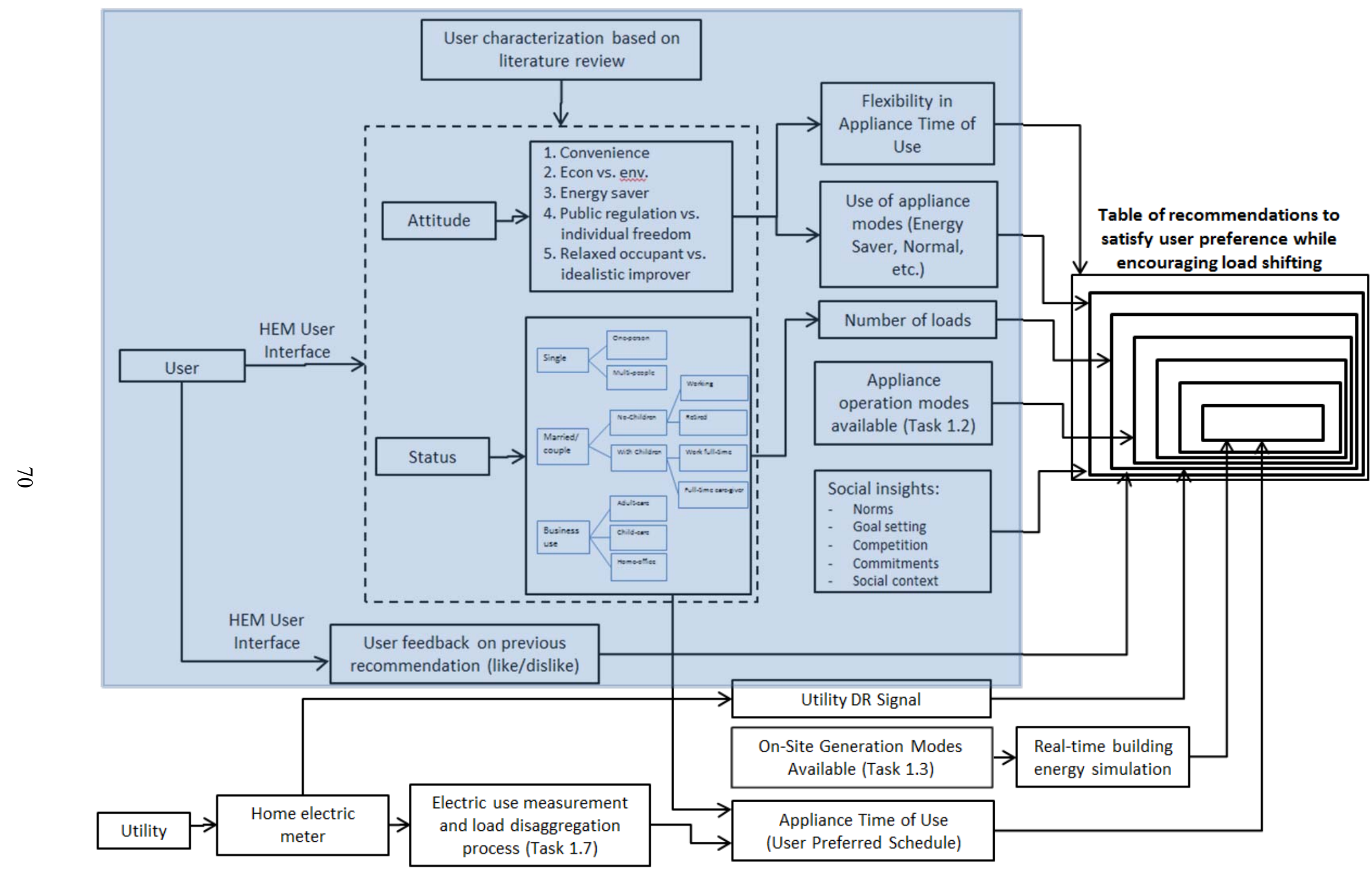

Figure 1.5-26. The process of deriving and generating recommendations using user characterization and preference 


\subsection{A Review of Algorithms to Infer Occupant Preferences}

This task will document the review of algorithms from existing literature focusing on residential data to:

1. Infer periods of occupancy;

2. Infer electrical energy usage patterns and occupant preferences; and

3. Define potential usage recommendations for occupant feedback.

An algorithm found to be successful in the above could be considered as a candidate for integration into a Context-Aware Adaptive Home Energy Management (CASHEM) system.

\subsubsection{Algorithms to Infer Periods of Occupancy}

Within the domain of HEM, knowledge of occupancy conditions in the home are required to analyze energy use data. To minimize intrusion and increase occupant acceptance, it is preferred to infer occupancy indirectly. Occupancy information may be binary, or have a numerical value indicating the number of occupants, or be a model with the ability to estimate occupancy in the future based on conditions at that time. In this section, binary occupancy is first addressed.

Occupancy may be determined through examining patterns of appliance use. For example, repeating patterns in day and time of appliance use, and the sequential use of appliances such as relations between the use of a dish washer and a clothes washer may be related. Two methods may be considered to determine such occupancy information - those that use only measured electrical data and those that make use of electrical data combined with additional sensors. For example, an estimation of internal thermal loads calculated through additional temperature sensors, may be used to detect occupancy with the assumption that occupants contribute measurably to thermal load. More directly-measured occupancy data may be available from infrared sensors, pyro-electric detectors, and/or visual sensing cameras. This can be seen in ( $\mathrm{Yu}, \mathrm{Wu}, \mathrm{Lu}, \& \mathrm{Fu}, 2006)$, where the authors use multi-camera and sensory floor approaches to accurately estimate human positions within a home environment. The authors include an image showing a sensor grid on the floor that appears to be at a spacing of $30 \mathrm{~cm}$. The authors report that $78 \%$ of the time the difference between the actual position of the occupant and the estimated position is less than $30 \mathrm{~cm}$.

In (Lam, Höynck, \& Dong, 2009), the authors present a study that develops algorithms for occupancy number detection based on the analysis of environmental data captured from ambient sensing networks. Three machine learning methods - Support Vector Machines, Neural Networks and Hidden Markov Models were investigated to process the sensor data for the estimation of occupancy numbers for a typical daily schedule. Although this work was performed in an open plan office environment, it has input into a residential setting. Results of this work indicate that, due to the characteristics of the open office plan, $\mathrm{CO}_{2}$ and acoustic parameters have the largest correlation with the number of occupants in the space. An average of $80 \%$ accuracy on the occupancy number detection was achieved by Hidden Markov Models during testing periods. 
In addition, features to determine occupancy are currently present in some commercially available residential thermostats. An article in USA Today ${ }^{1}$ included three commercially available thermostats (Nest Ecobee, and Honeywell) with features that include determining when an occupant is present and also features to estimate occupant behavior.

Nest claims to learn user habits and create programs to meet the user's energy needs in the most efficient way possible. In addition to monitoring and adjusting the temperature, it measures ambient light, humidity, and motion, using the information to fine-tune its program. If it detects that the user is not home, it has the ability to adjust temperature accordingly, even if the standard program dictates otherwise.

Canadian company Ecobee's Smart Thermostat is similar in functionality to the Nest. It uses data from sensors and embedded algorithms to create a model of a home's energy use patterns and provides 'insights' into the home's energy performance The LCD touchscreen interface includes programming functions, an energy conservation mode, and five-day weather forecasts. It can also be controlled through a smart phone or other mobile device.

The Honeywell Prestige 2.0 Comfort System offers "interview-based programming" that asks questions about the resident's usage habits and configures the device to best take advantage of those habits.

The next section discusses algorithms that go beyond directly measuring the presence or absence of occupants and create models of appliance usage patterns through the measurement and analysis of electric use.

\subsubsection{Algorithms to Infer Electrical Energy Usage Patterns and Occupant Preferences}

In this section, existing algorithms to create models of occupant's use patterns and preferences are examined. These models enable the anticipation of the time of appliance use and preferences based on the quantity of electricity used. Data for creating these models is often collected using techniques of Nonintrusive load monitoring $\left(\mathrm{NILM}^{2}\right)$. Aside from the cost for special measuring devices, the intrusion into the local installation is the main problem for reaching a high market distribution. The use of standard digital electricity meters could avoid this problem but the loss of information of the measured data has to be compensated by more intelligent algorithms and implemented rules to disaggregate the total load trace of only the active total power measurements. In (Zeifman \& Roth, 2011), the authors review various NILM algorithms. They classify them based on whether they use low frequency data or high frequency data. Low frequency techniques use measurements of real power only or real and reactive power. They may include the measurement of additional macroscopic signatures. High frequency methods consider Harmonics and Fourier Transforms. The authors state that even though most of NILM uses some measures to demonstrate the algorithm success, there is no agreement upon what accuracy metric shall be used. Their review suggests several conclusions:

\footnotetext{
${ }^{1}$ http://usatoday30.usatoday.com/tech/products/story/2012-05-06/smart-thermostats/54750056/1, Updated 5/7/2012 11:18 AM, accessed 1/2/2013

${ }^{2}$ Non-intrusive load monitoring (NILM) is also referred to as Non-intrusive appliance load monitoring (NIALM). In this document we will use the term NILM.
} 
1. No complete NILM solution suitable for all types of household appliances is available. The available solutions are either unsuitable for some appliances or still at an early developmental stage.

2. No complete set of robust, widely accepted appliance features has been identified. The available features do not provide for unambiguous and distinct appliance detection and classification. Using more mutually-independent features improves accuracy, albeit with higher false positive rates.

3. Using several 'orthogonal' disaggregation algorithms may improve accuracy, but optimal fusion needs to be implemented.

4. Relative operating characteristics curves could be used for algorithm benchmarking.

In (Zukerman \& Albrecht, 2001) the authors review two methods of predictive statistical modeling of user behavior: content-based and collaborative. Content-based learning is used when a user's past behavior is a reliable indicator of the user's future behavior. Collaborative learning is used whenever one can assume that a user behaves in a similar way to other users. The authors state that the limitations of traditional knowledge representation methods for modeling human behavior led to the investigation of such statistical models. The statistical models may be linear models, term frequency inverse document frequency (TFIDF)-based models, Markov models, neural networks, classification, rule-induction, or Bayesian networks.

The content-based approach is suited for tailoring a system's behavior to the specific requirements of a particular user. However, this approach requires each user to provide relatively large amounts of data to enable the construction of a statistical model. In addition, the features selected when implementing this approach have a substantial effect on the usefulness of the resulting model. Features that are too specific yield a system that is useful only for repetitive behaviors, while features that are too general yield predictions of debatable usefulness.

The collaborative approach reduces the data collection burden for individual users, and can be implemented using the specific values of the data (without obtaining features with the 'right' level of abstraction). However, since this approach makes predictions about the behavior of a single user from observations of many users, it does not support tailoring a system to the requirements of a particular user. Furthermore, most systems that implement this approach merge all users into a model that represents an 'average' user. This prevents modeling the behavior of different types of users, e.g., an undergraduate student versus a police officer.

To remedy this situation, predictive statistical models built with the collaborative approach must be extended to model the characteristics of groups of users, as described in (Alspector, Koicz, \& Karunanithi, 1997) and (Horvitz, Breese, Heckerman, Hovel, \& Rommelse, 1998). These enhanced models can then make more accurate predictions about the behavior of individual users by matching these users to a particular group. Nonetheless, even with the improved predictive accuracy of these models, the fundamental inability of the collaborative approach to represent the idiosyncrasies of individual users calls for a solution which combines both types of modeling approaches (Alspector, Koicz, \& Karunanithi, 1997) and (Degado \& Ishii, 1999).

An important issue that emerges pertains to the variety of techniques being applied to build predictive statistical models. At present, the only justification given for preferring a particular modeling technique is its empirical success, either in isolation or compared with that of other methods. Ideally, a predictive model should have both high recall (predicted probability) and high precision (accuracy). Recall measures 
the proportion of items of interest recommended by a system among the items of interest in the system's knowledge base, and precision measures the proportion of items of interest among the items recommended by the system.

Accuracy and predicted probability are measures used to evaluate models that predict a user's actions, locations or goals. Accuracy calculates the percentage of times the event that actually occurred was predicted with the highest probability (over several trials), while predicted probability returns the average of the probabilities with which this event was predicted (over several trials).

In (Cook, Youngblood, \& Heierman, 2003), the authors present a smart home architecture 'MavHome' (Managing an Intelligent Versatile Home), which allows a home to act as an intelligent agent. Prediction algorithms are introduced including compression-based prediction, prediction using a task-based model, Markov Model, Episode Discovery, Meta-Prediction and Prediction Using Sequence Matching. The authors state that results from synthetic and real collected smart home data indicate that the predictive accuracy is high even in the presence of many possible activities. The author's algorithm allows each of these prediction approaches to play a role in predicting inhabitant activity. The authors demonstrate the effectiveness of these algorithms on smart home data but have yet to test MavHome on complex environments with multiple occupants.

This algorithm was tested using synthetic smart home data and real data collected by students. In these experiments, the algorithm yields a predictive accuracy as high as $53.4 \%$ on the real data and $94.4 \%$ on the synthetic data. The advantages of this method are its design simplicity and ability to incrementally use all collected history.

The algorithm matches the most recent sequence of events with sequences in collected histories. When the inhabitant issues a command to a device, it is recorded in the inhabitant history. A match identifies a sequence in history that matches the immediate event history. A match queue is maintained to ensure a near-linear run time. Therefore, a key disadvantage to this approach is the fact that the entire action history must be stored and processed off line, which is not practical for large behavior prediction tasks over a long period of time. In (Barbato, Borsani, Capone, \& Melzi, 2009), the authors present a work in progress within the European project $\mathrm{AIM}^{1}$ for the design of a system that can minimize energy waste in home environments efficiently managing devices operation modes.

In their architecture the authors proposed a heterogeneous hierarchical sensor network to monitor physical parameters like light and temperature as well as the presence of users at home and in each room. With the data the system creates profiles of the behavior of house inhabitants and through a prediction algorithm automatically set system parameters in order to optimize energy consumption and cost while guaranteeing the required comfort level. Based on user profiles and real-time information provided by the system, user behavior can be predicted and the energy consumption is optimized by automatically controlling appliances. When users change their habits due to unpredictable events, the system is able to detect wrong predictions by analyzing real time information from sensors and modify system behavior accordingly.

The authors claim that by the automatic control of energy management system it is possible to avoid complex manual settings of system parameters that would prevent the introduction of home automation

\footnotetext{
${ }^{1}$ AIM - A novel architecture for modeling, virtualizing and managing the energy consumption of household appliances. http://www.ict-aim.eu/
} 
systems for energy saving into the mass market. The authors also claim that the presented solution is simpler than other profiling systems which rely on complex learning techniques: just replicating a previously observed set up that satisfied the user in a similar context provides good results and requires shorter training periods. The authors state that in a simulation environment, the percentage of correctly predicted profiles for each room in a five-room simulated house is $87 \%$ to $94 \%$.

In (Berges, Goldman, Matthews, Soibelman, \& Anderson, 2010), the authors examine residential buildings and how NILM provides energy consumption and operation schedule of electrical appliances in order to conserve energy. Here, the algorithms detect current and voltage and calculate power demand of the house or appliance. In their paper, the authors include an image of the load disaggregation algorithm flowchart showing the processing blocks for Edge Detection, Feature Extraction and Classification. The researchers obtained several inexpensive commercially available sensors capable of wireless signal transmission. They have found that the measured real power and power factor showed large differences between the meters, of the order of $10-20 \%$, whereas the documented accuracy of each metering device is $3 \%$ or better. At the same time, no pattern for the inter-device variation could be detected in order to establish scaling factors. Because of these measurement discrepancies, the authors built their own data acquisition system, based on a commercially available oscilloscope. The features used by the authors are the calculated real and reactive power and the transient features in terms of the regression coefficients of a non-linear fit to fast Fourier transform (FFT). The matching algorithms considered are standard pattern recognition classifiers (nearest-neighbor and Bayes). The reported accuracy ranges from $67 \%$ to $100 \%$.

In (Baranski \& Voss, 2004), the authors present a NILM algorithm based on a series of clustering methods. This is used to create hypothetical finite state machines to model detectable appliances. The authors state that patterns of refrigerators, electric flow heaters, stoves or a cookers could be detected but do not provide specific results.

In (Sultanem, 1991) the author presents a paper that shows that a local measurement of variations in active and reactive power is sufficient in most cases to identify an appliance. The authors study the wave shapes and spectra of some electrical household appliances and synchronized them with appliance events. In a second stage, a sorting algorithm identifies the appliance that has operated.

Switching an appliance on or off is generally done with other appliances already in operation. The author states that identification is therefore not linked to the current value but to its variation. In this paper it is shown that in steady-state conditions, the current set up by a large number of electrical household appliances experiences two types of fluctuations: (1) fluctuations due to load variations, as in the case of a vacuum cleaner or the motor of a washing machine; and (2) a drift linked to the increase in resistivity due to heating. This is the case of most heating appliances which only reach a stable regime after several minutes of operation.

The author recommends that the measurement device should detect events corresponding to a current variation and put them in parametric form by differentiating between conditions before and after the event. This kind of detection is difficult to perform with a purely analog device because the issue is to detect level variations, not a rated level. The author states that continuous measurement techniques are suitable for this detection. This technique consists of performing on-going measurement of the current signal by integrating it over a small number of periods ( 5 to 10 periods) and comparing each measurement with the former. If a variation is detected, it can then be analyzed and the identification parameters computed locally. The author concludes that this method has several advantages including the detection of events can be accurate since it can involve complex numerical tests. 
Work related to NILM includes appliance energy management. For example, in (Kishore \& Snyder, 2010), mechanisms to optimize electricity consumption within a home and across multiple homes in a neighborhood were demonstrated. The homes are assumed to use energy management controllers (EMCs) to control the operation of some of their appliances. The EMCs use both prices and user preferences to control power usage across the home. The authors proposed a distributed scheduling mechanism to reduce peak demand within a neighborhood of homes. The mechanism provides homes a guaranteed base level of power and allows them to compete for additional power to meet their needs. The authors also introduce a EMC optimization model based on dynamic programming, which accounts for the potential for electricity capacity constraints.

In addition, researchers have focused on hardware and communication techniques to enable load monitoring. In (Cabrer, 2006), the authors detail network communication technologies that can be installed into a system to create a dynamic environment that responds to user actions based on the previous data. This previous data is based on the user's use of an appliance, however, utility price information is not considered.

\subsubsection{Proposed Path for Algorithm Development}

Literature indicates that the research effort for NILM noted above has been focused on signature exploration and less on algorithm development. Signature exploration is defined to seek a combination of appliances such that the resultant aggregate signal is as close to the observed signal (i.e., measured electrical use) as possible. The energy use patterns for numerous appliances are matched simultaneously to the detected features over a prolonged period of time. Signature exploration utilizes more information and is expected to provide better disaggregation performance. On the other hand, the development of algorithms such as regression analysis seems to be more robust for appliances with unknown signatures. With the assumption that signatures of major appliances in a home are known, methods based on signature exploration appear to be suitable.

In addition, the NILM method employed may be determined by the resolution of data required whether it is sufficient to determine occupied or unoccupied, or it is necessary to know the number and location of the occupants. However, at this stage of the CASHEM project, we focus on determining appliance use patterns. By modeling the end use loads in detail, it is possible to evaluate how technologies such as DR and energy efficiency programs will affect the electric energy consumption and further HEM development.

A study by PNNL (Taylor, 1990) focused on day-type information ${ }^{1}$ to assist in studying energy use patterns. The method used in this work of determining clusters in data can be extended to CASHEM. When analyzing residential energy use, this study proposed a method whereby in addition to grouping data based on season, data is also grouped based on weekday, weekend and day after a holiday. Such a filtering technique is expected to increase the accuracy of the data analysis processes for load disaggregation that follow. Most studies already employ such disaggregation; however, literature was not found on studies that consider "day after a holiday".

Detection algorithms based on models that consider power, impedance and current may provide improved performance compared to existing methods described previously. In (Schneider \& Fuller,

\footnotetext{
${ }^{1}$ Day — type includes data that can be binned or filtered by time of day, day of week, week of month, month, or year.
} 
2010), the authors state that a simple load model consisting of a combination of constant power, constant impedance, and constant current elements is sufficient for a single point in time; however, the exact model values are difficult to determine and it is inadequate for some time-series simulations. The authors examine how to improve simple time invariant load models and develop multi-state time variant models to capture the effects on energy consumption, rather than single point power demand. The voltage response of a device is modeled as a collection of constant impedance, constant current, and constant power elements. This approach is illustrated in a 'ZIP' ${ }^{11}$ model (Table 1.6-1) (Schneider \& Fuller, 2010). In a time-variant load representation, the coefficients of the ZIP model, $V_{\mathrm{n}}, S_{\mathrm{n}}, Z \%, I \%, P \%, Z_{\theta}, I_{\theta}$, and $P_{\theta}$, remain constant, but the power demand, $P_{i}$ and $Q_{i}$, of the $i^{\text {th }}$ load varies with the actual terminal voltage, $V_{a}$. The ZIP model only varies the power demand as a function of actual terminal voltage, $V_{a}$.

Table 1.6-1. ZIP models are two state models, energized and de-energized. When energized there is only a single operational state and the energy consumption can be determined using (1) for real power, (2) for reactive power, and (3) as a constraint. Source: (Schneider \& Fuller, 2010)

$$
\begin{aligned}
P_{i}= & {\left[\frac{\left|V_{a}^{2}\right|}{\left|V_{n}^{2}\right|} \cdot\left|S_{n}\right| \cdot Z_{\%} \cdot \cos \left(Z_{\theta}\right)+\frac{\left|V_{a}\right|}{\left|V_{n}\right|} \cdot\left|S_{n}\right| \cdot I_{\%}\right.} \\
& \left.\cdot \cos \left(I_{\theta}\right)+\left|S_{n}\right| \cdot P_{\%} \cdot \cos \left(P_{\theta}\right)\right] \\
Q_{i}= & {\left[\frac{\left|V_{a}^{2}\right|}{\left|V_{n}^{2}\right|} \cdot\left|S_{n}\right| \cdot Z_{\%} \cdot \sin \left(Z_{\theta}\right)+\frac{\left|V_{a}\right|}{\left|V_{n}\right|} \cdot\left|S_{n}\right| \cdot I_{\%}\right.} \\
& \left.\cdot \sin \left(I_{\theta}\right)+\left|S_{n}\right| \cdot P_{\%} \cdot \sin \left(P_{\theta}\right)\right] \\
100= & Z_{\%}+I_{\%}+P_{\%}
\end{aligned}
$$

where

$P_{i} \quad$ real power consumption of the $i$ th load;

$Q_{i} \quad$ reactive power consumption of the $i$ th load;

$V_{a} \quad$ actual terminal voltage;

Vn nominal terminal voltage;

$S_{n} \quad$ apparent power consumption at nominal voltage;

$Z_{\%} \quad$ percent of load that is constant impedance;

$I_{\%} \quad$ percent of load that is constant current;

$P_{\%} \quad$ percent of load that is constant power;

$Z_{\theta} \quad$ phase angle of constant impedance component;

$I_{\theta} \quad$ phase angle of constant current component;

$P_{\theta} \quad$ phase angle of constant power component.

In the development of NILM methods for CASHEM, future algorithm development could examine the development of such ZIP models from measured electrical data and employ a method of signature exploration to compare measured use with stored appliance signatures.

\footnotetext{
${ }^{1}$ ZIP models are two state models, energized and de-energized. The ZIP model is similar to the polynomial representation used in many commercial software packages. In the polynomial representation of the ZIP load, the constant coefficient is equivalent to $P \%$, the linear coefficient is equivalent to $I \%$, and the quadratic coefficient is equivalent to $Z \%$.
} 
In the case of a dishwasher ${ }^{1}$, each state in the dishwasher model is shown in Figure 1.6-1 is governed by a ZIP model with transitions between states determined by internal state transition rules. The default ZIP components for each heating coil are modeled as $100 \%$ constant impedance, and motor at $100 \%$ constant power. All coils in this model are assumed to be the same ZIP fraction. The dishwasher model shown in Figure 1.6-1 d was developed in GridLAB-D as a multi-state load model. These states are defined by the level of their electricity consumption and they are: State 1 (off), State 2 (Control only), State 3 (Motor only), State 4 (Motor and coil) and State 5 (Heated dry). Source:

http://sourceforge.net/apps/mediawiki/gridlab-d/index.php?title=Spec:Dishwasher
(1) State 1: Off
(3) State 3: Motor only
(5) State 5: Heated dry
(2) State 2: Control only
(4) State 4: Motor and coil

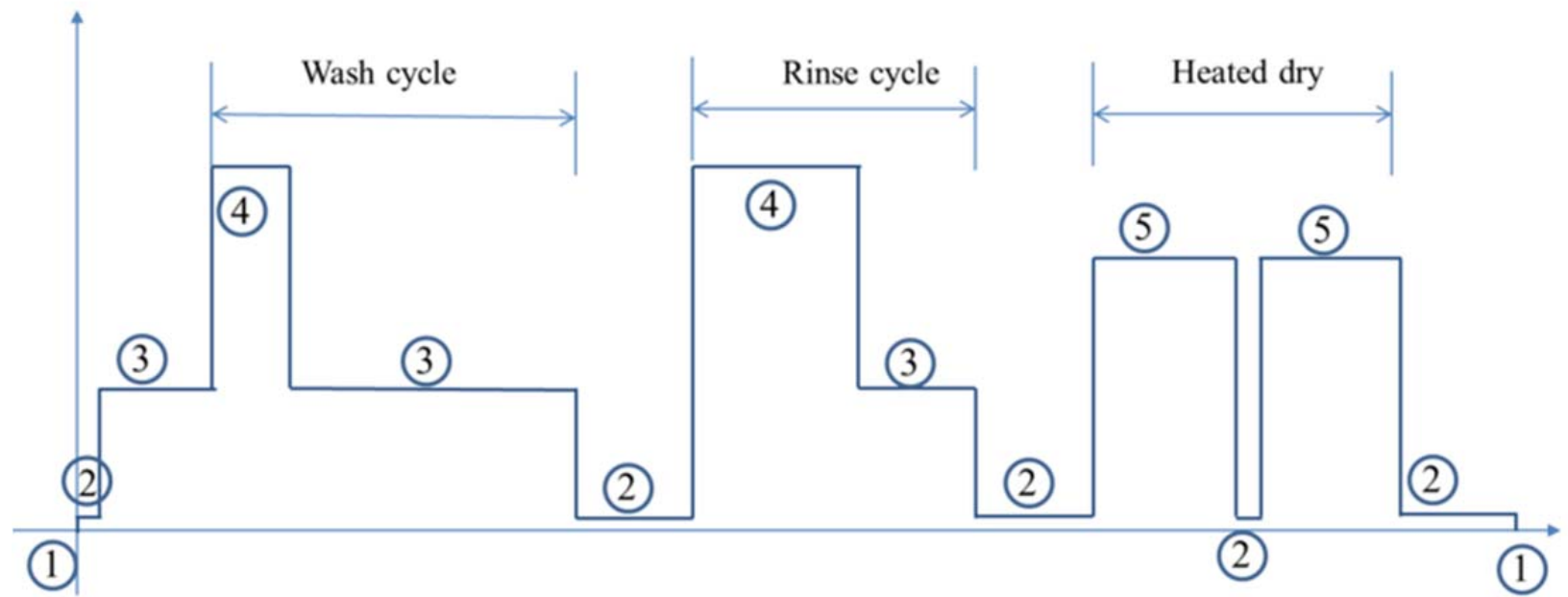

Figure 1.6-1. Dishwasher model from GridLAB-D

If only the motor is running (i.e., State 3):

- Load power $[\mathrm{kW}]=$ power $_{\text {motor }}[\mathrm{VA}] \cdot$ power factor $_{\text {motor }}$

- Load current $[\mathrm{kW}]=0$

- Load impedance $[\mathrm{kW}]=0$

If heating coil is only ON (i.e., State 2 and State 5):

- Load power $[\mathrm{kW}]=0$

- $\quad$ Load current $[\mathrm{kW}]=0$

- Load impedance $[\mathrm{kW}]=$ heating_element_capacity $[\mathrm{kW}]$

If heating coil and motor are ON (i.e., State 4):

- $\quad$ Load power $[\mathrm{kW}]=$ power $_{\text {motor }}[\mathrm{VA}] \cdot$ power factor $_{\text {motor }}$

- $\quad$ Load current $[\mathrm{kW}]=0$

\footnotetext{
${ }^{1}$ Specifications of the dishwasher class in the GridLAB-D residential module. Source: http://sourceforge.net/apps/mediawiki/gridlab-d/index.php?title=Spec:Dishwasher
} 
- Load impedance $[\mathrm{kW}]=$ heating_element_capacity $[\mathrm{kW}]$

Energy calculation:

- Total power $[\mathrm{kW}]=$ Load power $[\mathrm{kW}]+$ Load current $[\mathrm{kW}]+$ Load impedance $[\mathrm{kW}]$

- Energy used $[\mathrm{kWh}]=$ Total power $[\mathrm{kW}] \cdot \Delta t[\mathrm{sec}] / 3600$

Furthermore, it is required to address uncertainty in the estimated models. In (Lu \& Chassin, A state queueing model of thermostatically controlled appliances, 2004), the authors develop a state-queuing (SQ) model to analyze the price response of aggregated loads consisting of thermostatically controlled appliances (TCAs). TCAs include residential HVAC systems, electric water heaters, and refrigerators. In (Lu, Chassin, \& Widergren, Modeling Uncertainties in Aggregated Thermostatically Controlled Loads Using a State Queueing Model, 2005), the authors discuss the modeling of uncertainties in aggregated thermostatically controlled loads using the SQ model. The cycling times of TCAs vary with the TCA types and sizes, as well as the ambient temperatures. The random consumption of consumers, which shortens or prolongs a specific TCA cycling period, introduces another degree of uncertainty. By modifying the state transition matrix, the authors show that these random factors can be taken into account in a discrete SQ model. Such methods of addressing uncertainty should also be included in the scope of future NILM work.

\subsubsection{Define Potential Usage Recommendations for Occupant Feedback}

In this section, existing tools and algorithms are investigated that:

1. Provide immediately implementable recommendations, e.g., change in appliance operation mode or schedule, or on-site generator setpoint or schedule.

2. Suggestions on when to use the appliance and/or on-site generation source based on a variable utility rate, reduction in environmental impacts, etc.

3. Long term recommendations, e.g., information on equipment degradation obtained by categorizing and examining watt traces of the appliances.

Algorithms are investigated that provide performance feedback to the occupant-based performance assessment-against-self, as well as performance assessment against a peer group, to reduce energy use through user behavior modification.

\subsubsection{User Feedback and Behavior Programs}

In (Darby, 2006), the author documents financial and energy savings available through feedback technology. The author confirms that domestic energy consumption is still largely invisible to millions of users and this is a prime cause of waste and that feedback to the user on consumption is necessary for energy savings; however, it is not always sufficient, the author writes - "sometimes people need help in interpreting their feedback and in deciding what courses of action to take".

Immediate direct feedback from user-friendly displays promotes savings from daily behavior in nonheating end-uses. In the longer term, informative billing and annual energy reports can promote investment as well as influencing behavior. The author reports that savings have been shown in the region 
of 5-15\% and 0-10\% for direct and indirect feedback respectively. Direct displays in combination with improved billing show promise for early energy and carbon savings, at relatively low cost. They also lay the foundations for further savings through improved energy literacy.

The author states that user-friendly displays are needed as part of any new meter specification. Monitors would be most useful if they showed instantaneous usage, expenditure and historic feedback as a minimum, with the potential for displaying information on micro generation, tariffs and carbon emissions (linked to disclosure in the bill of the emissions factor of their supply).

Feedback is of value in itself as a learning tool and must be seen in context. The outcomes from feedback will vary according to circumstances, but they can also sometimes be improved by using feedback in conjunction with advice and information.

In (Darby, 2006), the author concludes that important factors influencing the effectiveness of feedback are:

1. General context, e.g., social, educational and historical factors, energy infrastructure.

2. Scale and timing of usage. Indirect feedback is most likely to give a compelling picture of what is happening to the heating load, while instantaneous direct feedback illustrates the impact of smaller end-uses.

3. Billing or other periodic feedback (e.g., via a computer or mobile device) will show longer term effects best, e.g., investment in insulation, new appliances, new heating system, home extensions (e.g., the addition of floor space, or other modifications such as the addition of shading devices), or additional members to the household. Direct/instantaneous displays will show the significance of moment-to-moment behavior best.

Existing work also includes (Friedrich, Amann, Vaidyanathan, \& Elliot, 2010), where the authors provide examples of successful behavioral programs that reduce customer energy use in order to attempt to achieve carbon emission reduction and economic goals. In this paper, the authors do not provide details on the specific behavior programs or algorithms used; however, they conclude that effective behavior programs take an interest in their audience and collect data on who customers are and what they want through market segmentation. The author states that utility programs have used evaluation methods that reveal some of the factors involved in saving energy - visibility, social norms, competition and user friendliness - but frequently do not go far enough in analyzing the effects of these factors. The ability to see energy efficiency/savings from the perspective of program participants is essential for success.

\subsubsection{Software Tools Currently Used to Generate Feedback}

In this section, we examine existing tools that provide feedback to users. In (SENTECH, Inc., 2010), the authors review home energy audit tools including REM/Rate ${ }^{1}{ }^{1}$, BEACON Home Energy Advisor ${ }^{\circledR}{ }^{2}$, Energy Insights ${ }^{\circledR}{ }^{3}$, Home Energy Tune-uP ${ }^{4}{ }^{4}$, Energy Gauge ${ }^{\circledR}{ }^{1}$, TREAT ${ }^{\circledR}{ }^{2}$, the National Energy Audit

\footnotetext{
${ }^{1}$ http://www.archenergy.com/products/remrate

2 http://scegportal.icfi.com/resources/BEACON\%20CONTRACTOR\%20USER\%20GUIDE-\%20Updated\%202011$02-15 . \mathrm{pdf}$

$\frac{02-15 . p}{3}$ http://www.apogee.net/products/energyInsights.aspx

4 http://www.homeenergytuneup.com/
} 
Tool (NEAT $\left.{ }^{\circledR}\right)^{3}$, Home Energy Saver ${ }^{\mathrm{TM}}$ Professional (HESPro $)^{4}$, and Real Home Analyzer ${ }^{\circledR}{ }^{5}$. Not included in their study are audit tools under DOE oversight or influence such as, Manufactured Home Energy Audit (MHEA) ${ }^{6}$, Home Energy Yardstick ${ }^{7}$, and other specialized tools designed for specialized purposes such as HVAC loads or for localized utility program energy efficiency efforts. The authors state that tool recommendations, if generated, consist of either automatically-generated, as programmed into the tool, or via user input, either through libraries or conditional lists. Energy efficiency measures are prioritized on the basis of local program initiatives, estimated cost-effectiveness of improvement activities, other factors such as health and safety issues, or a combination thereof.

These web-based audit tools, while addressing the whole house, are simple in scope, as few characteristics are input and the recommended measures reported are general in nature. Findings of the study report that no one tool fully captures all the characteristics currently thought to be important to a national home performance assessment program: low cost, universal availability, ease of use with reasonable input requirements, conformance to a universally accepted accuracy standard, and the ability to generate improvement recommendations and associated costs. The audit tools as a population, however, appear to address the potential needs of a national program. Some specific tools are described below:

Home Energy Yardstick analyzes energy bill data, compares usage to other households across the nation, and provides links to the Home Energy Advisor to explore potential improvement measures such as air sealing and insulating the home.

Home Energy Saver is analytical and is based on user inputs; the tool presents recommended energy efficiency measures with expected cost savings and payback. Home Energy Saver calculates an energy factor for appliances based on name plate information. This is an assimilation tool with the ability to estimate energy consumption for different end uses. In (Mills, 2008), the author states that a body of qualitative decision-support information augments the analytical results; however, the author does not provide details of the qualitative recommendations provided to the user.

National Energy Audit Tool (NEAT $\left.{ }^{\circledR}\right)$, (Gettings, Krigger, \& Fishbaugher, 2001) assists agencies to select energy conservation measures for primarily single-family site-built homes that meet government criteria for cost effectiveness. NEAT currently examines 34 energy conservation measures related to insulation and replacing inefficient equipment; however, the tool does not consider appliance operation modes or time of use.

${ }^{1}$ http://www.energygauge.com/

2 http://psdconsulting.com/software/treat/

3 http://weatherization.ornl.gov/assistant.shtml

4 http://hespro.lbl.gov/pro/

5 http://credit.csgrp.com/webapps/nyserda/InstructionManuals/11.07.21\%20RHA Manual_HPwES Program_pdf

6 http://eber.ed.ornl.gov/pub/weatherization/Manuals/MHEA\%20Users.pdf

7 http://www.energystar.gov/index.cfm?c=home improvement.hm_improvement index tools 
Home Asset Rating (ICF International, 2010) This tool uses algorithms that use simulated energy use, actual energy bills, and actual weather data, along with data inputs that are typically collected thru a visual inspection of the home. This data is then used to cross reference between the expected (i.e., simulated) and actual (i.e., metered) energy use to determine potential variances in end-use energy use on a monthly basis. The variations are then used by the algorithms to calibrate the asset rating and corresponding energy use prediction. Once the calculations are complete, the end result can show three separate energy use estimates for a single home - the first is the estimate asset rating energy use from the original calculations; the second is the operational rating based on the utility bills; and the final one is the algorithm modified asset rating energy use.

Real Home Analyzer (Conservation Services Group, 2010) is capable of estimating heating and cooling loads for homes. The user enters information about the home - the envelope and the HVAC system details - and also blower door measurements. A contractor (or a user) is able to review analysis and reports screen and revisit any measures for which there are data errors or missing information and add pricing to measures and create scenarios, proposals or contracts.

Existing appliances and home energy managers that do provide more detailed feedback to the user including suggestions on appliance operation schedule include GE Brillion ${ }^{\mathrm{TM}}$ Nucleus Energy Manager, Miele@home network and LG THINQ ${ }^{\mathrm{TM}}$ Technology that have been described in the Task 1.2 report.

\subsubsection{Proposed CASHEM User Recommendation Framework}

In the Task 1.6 Report, we propose a recommendation framework based on a lookup table of possible scenarios. This is shown in a schematic flowchart in Figure 1.6-2. We estimate nine independent parameters in the lookup table and approximately three values for each parameter. Recommendations are stored in the lookup table for different combinations of the nine independent parameters such that they satisfy the maximum number of constraints imposed by the parameters.

In an example use case, through the HEM interface the user enters an Attitude of "Energy Saver" and a status of "Family with Children". From these two pieces of information it is inferred that the user has "Flexibility in Appliance Time of Use" of three hours, uses the Energy Saver Appliance modes and may operate the dishwasher once per day. The number of times an appliance is used is taken as a constraint as this is based on the number of occupants in the home and may not be changed. If the user does not select Energy Saver, then each recommendation also includes an estimation of the energy and money saved as well as the environmental benefits if the user had selected Energy Saver. This is also to be implemented for Flexibility in Time of use, to inform the user of the benefits of being more flexible and contributing towards shifting the load.

It is assumed that the HEM is setup correctly during the installation of the HEM in the users' home for appliance operation modes available. From the algorithm employed for measurement of electric energy use and load disaggregation, the user's preferred time of use for the appliances is determined. This combination of parameters is used to generate recommendations for different cases as depicted in Table 1.6-2 below. Three specific examples are given in Table 1.6-2: (1) a case to delay the use of an appliance until the utility price signal is back to Normal; (2) a case to use an on-site generation device to enable the use of an appliance while the utility price signal is critical; and (3) a case to use one appliance, instead of two simultaneously, to reduce peak demand while the utility price is high. 


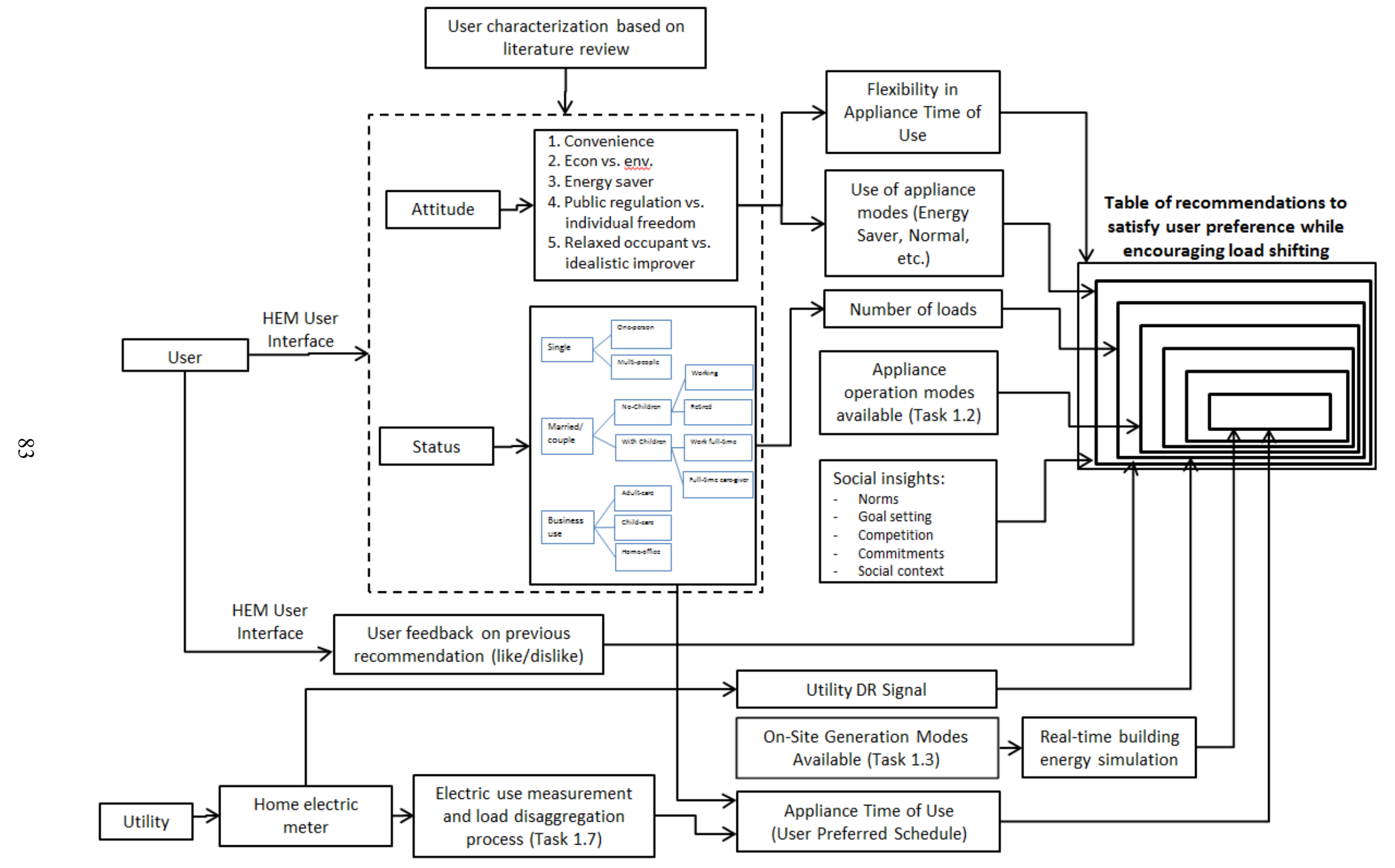

Figure 1.6-2. A flowchart for a proposed recommendation framework for CASHEM. 
Table 1.6-2. Example of recommendation for dishwasher for two different user types

\begin{tabular}{|c|c|c|c|c|c|c|c|c|c|c|c|}
\hline \multicolumn{3}{|c|}{$\begin{array}{c}\text { User Input using the HEM } \\
\text { Interface }\end{array}$} & \multicolumn{3}{|c|}{$\begin{array}{l}\text { CASHEM Analysis from } \\
\text { the User Input }\end{array}$} & \multicolumn{3}{|c|}{ Information Obtained During CASHEM Setup } & \multicolumn{2}{|c|}{$\begin{array}{c}\text { Information Obtained from a Smart } \\
\text { Meter }\end{array}$} & \multirow[t]{2}{*}{ Recommendation } \\
\hline Status & $\begin{array}{l}\text { Number } \\
\text { of } \\
\text { Occupants }\end{array}$ & Attitude & $\begin{array}{c}\text { Flexibility } \\
\text { in Time of } \\
\text { Use }\end{array}$ & $\begin{array}{l}\text { Appliance } \\
\text { Mode Used }\end{array}$ & $\begin{array}{l}\text { Number } \\
\text { of Loads }\end{array}$ & $\begin{array}{l}\text { Appliance } \\
\text { Modes } \\
\text { Available }\end{array}$ & $\begin{array}{l}\text { On-Site } \\
\text { Generation } \\
\text { Modes } \\
\text { Available }\end{array}$ & $\begin{array}{c}\text { Energy Used by a House in } \\
\text { the Same Peer Group vs. } \\
\text { Your House }\end{array}$ & $\begin{array}{l}\text { Utility DR Signal } \\
\text { (time in hours) }\end{array}$ & \begin{tabular}{|c|} 
User's Proffered \\
Appliance Time of \\
Use Known from \\
Historical Usage \\
Pattern \\
\end{tabular} & \\
\hline \multicolumn{12}{|c|}{ Example 1: This example advises the user to delay their use of an appliance based on the current DR signal from the utility. } \\
\hline \begin{tabular}{|l|} 
Family \\
with \\
Children
\end{tabular} & 4 & Energy Saver & 3 Hours & $\begin{array}{l}\text { Normal } \\
\text { Mode }\end{array}$ & $\begin{array}{l}3 \text { per } \\
\text { week }\end{array}$ & \begin{tabular}{|c|} 
Energy \\
Saving, \\
Normal, High \\
Temperature \\
Wash
\end{tabular} & None & 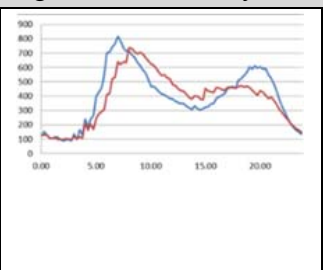 & $\begin{array}{c}2100 \text { - 1459: Normal } \\
1500 \text { - } 1759 \text { High } \\
1800 \text { - } 1959 \text { Critical }\end{array}$ & 1900 & \begin{tabular}{|l|} 
Wait to operate the \\
dishwasher till 2000 \\
- Money saved by \\
shifting is $\$$. \\
- Save $\$$ by operating the \\
dishwasher in Energy \\
Saving mode.
\end{tabular} \\
\hline \multicolumn{12}{|c|}{ Example 2: This example advises the user to use an on-site generation device to enable their use of an appliance while the DR signal from the utility is at the critical level. } \\
\hline Family & 2 & $\begin{array}{c}\text { Require } \\
\text { Convenience }\end{array}$ & None & $\begin{array}{l}\text { Normal } \\
\text { Mode }\end{array}$ & $\begin{array}{l}2 \text { per } \\
\text { week }\end{array}$ & \begin{tabular}{|c|} 
Energy \\
Saving, \\
Normal, High \\
Temperature \\
Wash
\end{tabular} & \begin{tabular}{|c|} 
Combined \\
Heat and \\
Power System
\end{tabular} & 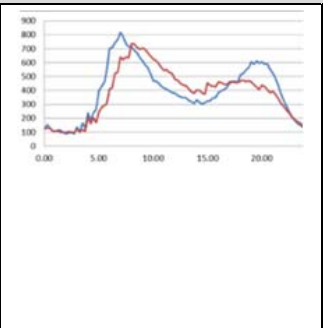 & $\begin{array}{c}2100 \text { - 1459: Normal } \\
1500 \text { - } 1759 \text { High } \\
1800 \text { - } 1959 \text { Critical }\end{array}$ & 1900 & $\begin{array}{l}\text { Use the On-Site generator } \\
\text { to fill in the peak demand } \\
\text { caused by using the } \\
\text { dishwasher at } 1900 \text {. } \\
\text { • Money saved by using } \\
\text { On-Site generator is } \$ \text {. } \\
\text { - Save } \$ \text { by operating the } \\
\text { dishwasher in Energy } \\
\text { Saving mode. }\end{array}$ \\
\hline \multicolumn{12}{|c|}{$\begin{array}{l}\text { Example 3: This example addresses a scenario where two appliances - dishwasher and clothes washer - may be used simultaneously and advice is given to the user to delay the use of one appliance } \\
\text { while the DR signal from the utility is at the high level to take into account a secondary effect on the electric water heater. }\end{array}$} \\
\hline Family & 2 & \begin{tabular}{c|c|c|c|c|} 
Require \\
Convenience
\end{tabular} & None & $\begin{array}{c}\text { Normal } \\
\text { Mode }\end{array}$ & $\begin{array}{l}2 \text { per } \\
\text { week }\end{array}$ & \begin{tabular}{|c|} 
Energy \\
Saving, \\
Normal, High \\
Temperature \\
Wash
\end{tabular} & None & 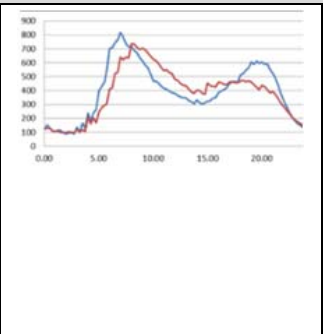 & $\begin{array}{c}2100 \text { - 1459: Normal } \\
1500 \text { - } 1759 \text { High } \\
1800 \text { - } 1959 \text { Critical }\end{array}$ & 1600 & $\begin{array}{l}\text { Delay the use of either the } \\
\text { dishwasher or the clothes } \\
\text { washer till } \\
\text { - Money saved by using } \\
\text { On-Site generator is } \$ \text {. } \\
\text { - Save \$ by operating the } \\
\text { dishwasher in Energy } \\
\text { Saving mode. }\end{array}$ \\
\hline
\end{tabular}




\subsection{References}

Agency, U. E. (n.d.). The ENERGY STAR Current. Retrieved July 18, 2012, from Energy Star: http://www.energystar.gov/

Allen, D. and Jonda, K. (2006). The Effects of Household Characteristics and Energy Use Consciosness on the Effectiveness of Real-Time Energy Use Feedback: A Pilot Study. ACEEE Summer Study on Energy Efficiency in Buildings.

Alspector, J., Koicz, A., \& Karunanithi, N. (1997). Feature-Based and Clique-Based User Models for Movie Selection: A Comparative Study. User Modeling and User-Adapted Interaction, 7(4), 279-304.

Association of Home Appliance Manufacturers. http://www.aham.org/

ATD - Home Inspection. (2010). Retrieved July 18, 2012, from Attention to Detail:

http://www.atdhomeinspection.com/average-product-life.htm

Baechler, M.C., Williamson, J., Gilbride, T., Cole, P., Hefty, M., and Love, P. (2010). Guide to Determining Climate Regions by County. Building America Best Practices Serie. Vol. 7.1. Last accessed on August 31, 2012 from http://apps1.eere.energy.gov/buildings/publications/pdfs/building_america/ba_climateguide 7 1.pdf

Baranski, M., \& Voss, J. (2004). Detecting Patterns of Appliances from Total Load Data Using a Dynamic Programming Approach. Proceedings of the Fourth IEEE International Conference on Data Mining.

Barbato, A., Borsani, L., Capone, A., \& Melzi, S. (2009). Home Energy Saving Through a User Profiling System Based on Wireless Sensors. BuildSys '09 Proceedings of the First ACM Workshop on Embedded Sensing Systems for Energy-Efficiency in Buildings (pp. 49-54). New York, NY: ACM.

Berges, M., Goldman, E., Matthews, H. S., Soibelman, L., \& Anderson, K. (2010). User-centric NonIntrusive Electricity Load Monitoring for Residential Buildings. SUBMITTED to the Journal of Computing in Civil Engineering.

Berry, C. (2009). Residential Energy Consumption Survey (RECS). Retrieved July 18, 2012, from U.S. Energy Information Administration: http://205.254.135.7/consumption/residential/data/2009/\#undefined

Blue Line Innovations. (2006). Summary: The Impact of Real-Time Feedback on Residential Electricity Consumption: The Hydro One Pilot. Last accessed on 1/9/2013 from:

http://www.bluelineinnovations.com/documents/reportsummaryhydroone0320.pdf

Brandon, G., \& Lewis, A. (1999). Reducing Household Energy Consumption: A Qualitative and Quantitative Field Study. Journal of Environmental Psychology, 19, 75-85.

Building Energy Codes Program. Residential Prototype Building Models. Last accessed on August 27, 2012 from http://www.energycodes.gov/development/residential/iecc_models/

Bureau, U. S. (2012). Nre Residential Sales. Retrieved July 18, 2012, from U.S. Department of Commerce: http://www.census.gov/construction/nrs/ 
Cabrer, M. R. (2006, May). Controlling the Smart Home from TV. IEEE Transactions on Consumer Electronics, 52(2), 421-429.

Cavallo, J., \& Mapp, J. (2000). Targeting Refrigeerators for Repair or Replacement. Retrieved July 18, 2012, from: http:/www.kouba-cavallo.com/art/REFRIG7a.pdf

Center, F. S. (2004). Oven Technology Assessment. Retrieved July 18, 2012, from

http://www.fishnick.com/equipment/techassessment/7_ovens.pdf

Chassin, D.P.; Schneider, K.; Gerkensmeyer, C. (2008). GridLAB-D: An open-source power systems modeling and simulation environment, IEEE 2008 PES Transmission and Distribution Conference and Exposition, 21-24 April 2008. http://dx.doi.org/10.1109/TDC.2008.4517260

Conservation Services Group. (2010). NYSERDA Home Performance with ENERGY STAR®: Real Home Analyzer User Manual. Conservation Services Group.

Cook, D. J., Youngblood, M., \& Heierman, E. O. (2003). MavHome: An Agent-Based Smart Home. Proceedings of the First IEEE International Conference on Pervasive Computing and Communications. Fort Worth, Texas: IEEE.

Crist, D. (n.d.). New and Existing Home Sales, U.S. Retrieved July 18, 2012, from National Association of Home Builders: http://www.nahb.com/fileUpload_details.aspx?contentID=55761

Darby, S. (2006). The Effectiveness of Feedback on Energy Consumption: A Review for Defra Of the Literature on Metering, Billing and Direct Displays. University of Oxford, Environmental Change Institute. Oxford, United Kingdom: University of Oxford.

Davis Energy Group. (2004). Codes and Standards Enhancement Initiative for PY2004: Title 20 Standards Development Analysis of Standards Options For Residential Pool Pumps, Motors, and Controls. Retrieved July 18, 2012, from Energy Solutions: http://consensus.fsu.edu/FBC/PoolEfficiency/CASE_Pool_Pump.pdf

Delgado, J., \& Ishii, N. (1999). Formal Models for Learning a User's Preferences, a Preliminary Report. Proceedings of the IJCAI99 Workshop on Learning about Users. Stockholm, Sweden.

District, N. P. (2009). Operating Costs of Household Appliances. Retrieved July 18, 2012, from Cornhusker Public Power District: http://www.cornhusker-power.com/householdappliances.asp

Ehrhardt-Martinez, K.,Donnelly, K. A., and Laitner, J.A. (2010). Advanced Metering Initiatives and Residential Feedback Programs: A Meta-Review for Household Electricity-Saving Opportunities. Report No. E105. Washington, DC: ACEEE.

Ehrhardt-Martinez, K. (2011). The Persistence of Feedback-Induced Energy Savings in the Residential Sector. Boulder, CO: the Renewable and Sustainable Energy Institute, University of Colorado.

ENERGY STAR. (2012). The ENERGY STAR Current. Retrieved July 18, 2012, from Energy Star: http://www.energystar.gov/ 
Energy, E. E. (2011). Estimating Appliance and Home Electronic Energy Use. Retrieved July 18, 2012, from Energy Savers: http://www.energysavers.gov/your_home/appliances/index.cfm/mytopic=10040

F, F. (2005). Appliance Cycling Evaluation. Retrieved July 18, 2012, from

http://policy.rutgers.edu/ceep/publications/2005/cycling.pdf

Friedrich, K., Amann, J., Vaidynathan, S., and Elliott, N. (2010). Visible and Concrete Savings: Case Studies of Effective Behavioral Approaches to Improving Customer Efficiency. American Council for an Energy-Efficient Economy. Washington, D.C.

Fuller, J.C., Vyakaranam, B., Kumar, N.P., Leistritz, S.M., \& Parker, G.B. (2012). Modeling of GE Appliances in GridLAB-D: Peak Demand Reduction. U.S. Department of Energy.

General Electric Company (2012). Last accessed on July 18, 2012 from http://www.geappliances.com/home-energy-manager/appliance-energy-consumption.htm

Gettings, M., Krigger, J., \& Fishbaugher, M. (2001). National Energy Audit (NEAT) Users Manual (Version 7). Oak Ridge National Laboratory, Energy Division. Oak Ridge, Tennessee: U.S. Department of Energy.

Gram-Hanssen, K. (2011). Household's Energy Use - which is the more important: efficient technologies or user practices? World Renewable Energy Congress 2011. Linkoping, Sweden.

GridLAB-D:Community Portal. (2009). Retrieved July 18, 2012, from Sourceforge:

http://sourceforge.net/apps/mediawiki/gridlab-d/index.php?title=gridlab-d:Community_Portal

Heaters. 77(114).35299-35304. Accessed on July 31, 2012 from

http://www1.eere.energy.gov/buildings/appliance_standards/pdfs/wh_rfi 2012_06 13.pdf

Hendron, R., \& Engebrecht, C. (2010). Building America House Simulation Protocols. National Renewable Energy Laboratory. U.S. Department of Energy Building Technologies Program. Last accessed on August 27, 2012 from

http://apps1.eere.energy.gov/buildings/publications/pdfs/building_america/house_simulation_revised.pdf

Herkel, S., Knapp, U., and Pfafferott, J. (2008). Towards a Model of User Behavior Regarding Manual Control of Windows in Office. Building and Environment, 43: 588-600.

Heslop, L.A., Moran, A., and Cousineau, A. (1981). 'Consciousness' in Energy Conservation Behavior: An Exploratory Study. Journal of Consumer Research 8: 299-305.

Higbee, J., Brehm, J., Sen, P. K., \& Ammerrnan, R. (2005). Residential Electric Power Systems: Implications for Distributed Generation. Colorado School of Mines. IEEE.

Hoes, P., Hensen, J. L. M., Loomans, M. G. L. C., de Vries,B., and Bourgeois, D. (2009). User Behavior in Whole Building Simulation. Energy and Buildings, Elsevier 41:295-302. 
Horvitz, E., Breese, J., Heckerman, D., Hovel, D., \& Rommelse, K. (1998). The Lumiere Project: Bayesian User Modeling for Inferring the Goals and Needs of Software Users. Proceedings of the Fourteenth Conference on Uncertainty in Artificial Intelligence. Madison, WI.

Household Appliances on the Smart Grid: Energy Management and Demand Response Applications, Communications Technologies, Standards, and Key Industry Players, Pike Research, accessed on March 8, 2012 from http://www.pikeresearch.com/research/smart-appliances

Suriya Ruangpattana, Diego Klabjan, Jorge Arinez, Member, IEEE, and Stephan Biller, Member, IEEE. Optimization of On-site Renewable Energy Generation for Industrial Sites

http://ieeexplore.ieee.org/xpls/abs all.jsp?arnumber $=5772448$

J. D. Wilson, Student Member, IEEE, C. M. Colson, Student Member, IEEE, and M.H. Nehrir, Fellow IEEE. Cost and Unit-sizing Analysis of a Hybrid SOFC/Microturbine Generation System for Residential Applications.

http://ieeexplore.ieee.org/xpl/articleDetails.jsp?reload=true\&arnumber=5619952\&contentType=Conferen $\underline{\text { ce+Publications }}$

ICF International. (2010). Existing Home Asset Rating Sensitivity Analysis, Existing Software Tool Comparison, and Methodology for Estimating Home Characteristics. Fairfax, VA: Submitted to: United States Department of Energy.

Is Food Warming Burning a Hole in Your Profit. (n.d.). Retrieved July 18, 2012, from Energy Efficient Enterprises: http://www.maced.org/E3/documents/E3\%20Deli\%20Equipment.pdf

Itron, I. (2005). Database For Energy Efficiency Resources (DEER) Update Study. Retrieved July 18, 2012, from Itron: http://www.calmac.org/publications/2004-05_DEER_Update_Final_Report-Wo.pdf

KEMA. (2009). Northwest Power and Conservation Council. Retrieved July 18, 2012, from End-Use Load Data Update Project Final Report:

http://neep.org/uploads/EMV\%20Forum/EMV\%20Products/KEMA\%20End\%20Use\%20Catalog\%20Rep ort $\% 20$ Executive $\% 20$ Summary $\% 20$ for $\% 20$ Web.pdf

Kishore, S., \& Snyder, L. V. (2010). Control Mechanisms for Residential Electricity Demand in SmartGrids. IEEE.

Lam, K., Höynck, M., \& Dong, B. (2009). Occupancy Detection through an Extensive Environmental Sensor Network in an Open-Plan Office Building. Eleventh International IBPSA Conference (pp. 14521459). Glasgow, Scotland: IBPSA.

LG (2012). Last accessed on July 18, 2012 from http://www.lgnewsroom.com/newsroom/contents/61738

Lin, Z., and Fu, L. (2007). Multi-user Preference Model and Service Provision in a Smart Home Environment. Proceedings of the $3^{\text {rd }}$ Annual IEEE Conference on Automation Science and Engineering. (pp. 759-764) Scottsdale, AZ, USA, Sep. 22-25, 2007.

Lu, N., \& Chassin, D. P. (2004, August). A state queueing model of thermostatically controlled appliances. IEEE Transactions on Power Systems 19(3), 1666-1673. 
Lu, N., Chassin, D. P., \& Widergren, S. E. (2005, May). Modeling Uncertainties in Aggregated Thermostatically Controlled Loads Using a State Queueing Model. IEEE Transactions on Power Systems 20(2), 723-733.

Matsukawa, I. (2004). The Effects of Information on Residential Demand for Electricity. Energy Journal. 25 (1): $1-17$.

Miele \& Cie. KG. Last accessed on July 18, 2012 from http://www.miele-projectbusiness.com/international/en/project_business/products/miele-at-home.aspx

Mills, E. (2008). The Home Energy Saver - Documentation of Calculation Methodology, Input Data, and Infrastructure. Lawrence Berkeley National Laboratory, Energy Analysis Department, Environmental Energy Technologies Division. Berkeley, CA: University of California.

Naesje, P.C., T.K. Andersen, H. Saele. (2005). Consumer Response on Price Incentives. ECEEE 2005 Summer Study: What Works and Who Delivers? 1259-1269.

NREL - National Renewable Energy Laboratory. (2002). Battery Power for Your Residential Solar Electric System. U.S. Department of Energy.

Neenan, B. (2010). Paying Upfront: A Review of Salt River Project's M-Power Prepaid Program. Electric Power Research Institute (EPRI). Palo Alto, CA. Last accessed on 1/9/2013 from: http://www.srpnet.com/environment/earthwise/pdfx/spp/EPRI_MPower.pdf

Noureddine, A.H., Alouani, A.T., and Chandrasekaran, A. (1992). On the Maximum Likelihood Duty Cycle of an Appliance and its Validation. IEEE Transactions on Power Systems, 7(1):228-235.

Pike Research. (2012). Community and Residential Energy Storage: Distributed Energy Storage Systems for Voltage Support, Frequency Regulation,. Navigant Consulting, Inc.

Precepts, H. (2007). Study of Life Expectancy of home Components. Retrieved July 18, 2012, from Home Precepts: http://www.homeprecepts.com/files/Life_Expectancy.pdf

Residential Energy Consumption Survey (RECS). (2009). Retrieved July 18, 2012, from U.S. Energy Information Administration: http://205.254.135.7/consumption/residential/data/2009/\#undefined

Ruangpattana, S., Klabjan, D., Arinez, J., \& Biller, S. (2011). Optimization of On-site Renewable Energy Generation for Industrial Sites. IEEE Power Systems Conference and Exposition. Phoenix, Arizona.

Sastry, C., Pratt, R., Srivastava, V., \& Li, S. (2010). U.S. Department of Energy. Retrieved July 18, 2012, from Use of Residential Smart Appliances for Peak-Load Shifting and Spinning Reserves Cost/Benefit Analysis. PNNL-19083, Pacific Northwest National Laboratory, Richland, Washington. http://www.aham.org/ht/a/GetDocumentAction/i/51596

Schneider, K. P., \& Fuller, J. C. (2010). Detailed End Use Load Modeling for Distribution System Analysis. Power and Energy Society General Meeting (pp. 1-7). Minneapolis, MN: IEEE. 
SENTECH, Inc. (2010). Review of Selected Home Energy Auditing Tools - In Support of the Development of a National Building Performance. Washington, D.C.: The U.S. Department of Energy, Office of Energy Efficiency and Renewable Energy.

Spec:Dishwasher. (2012, May 10). Retrieved July 18, 2012, from Sourceforge:

http://sourceforge.net/apps/mediawiki/gridlab-d/index.php?title=Spec:Dishwasher

Sultanem, F. (1991). Using Appliance Signatures For Monitoring Residential Loads At Meter Panel Level. IEEE Transactions on Power Delivery. 6-4, pp. 1380-1385. IEEE.

Taylor, Z. T. (1990). Daytyping Methodologies for Analyses of Commercial Building End-use Loads: End-use Load and Consumer Assessment Program. Pacific Northwest National Laboratory, Richland, Washington.

The Cadmus Group, Inc. (2010). Residential Retrofit High Impact Measure Evaluation Report. Retrieved July 18, 2012, from California Public Utilities Commission Energy Division:

http://www.calmac.org/publications/FinalResidentialRetroEvaluationReport_11.pdf

Tuffner, F., \& Kintner-Meyer, M. (2011). Using Electric Vehicles to Meet Balancing Requirements Associated with Wind Power. Pacific Northwest National Laboratory. United States Department of Energy.

U.S. Department Of Energy (DOE) (2012) Energy Conservation Program for Consumer Products and Certain Commercial and Industrial Equipment: Energy Conservation Standards for Residential Water Zpryme Research \& Consulting. (2010). Smart Grid Insights: Smart Appliances. Last accessed on July 18,2012 from http://www.zpryme.com/SmartGridInsights/2010 Smart Appliance Report Zpryme Smart Grid Insigh $\underline{\text { ts.pdf }}$

Walton, J. and B. Gohn (2010). Executive Summary: Smart Appliances, PikeResearch. http://www.pikeresearch.com/research/smart-appliances

Wilson, J. D. (2010). Cost and Unit-sizing Analysis of a Hybrid SOFC/Microturbine Generation System for Residential Applications. North American Power Symposium (NAPS), 2010 (pp. 1-6). IEEE.

Yamaguchi, Y., Fujimoto, T., and Shimoda, Y. (2011). Occupant Behavior Model for Households to Estimate High-Temporal Resolution Residential Electricity Demand Profile. Paper presented at the Proceedings of Building Simulation 2011. Sydney, Australia, November 14-16.

Yu, C.-R., Wu, C.-L., Lu, C.-H., \& Fu, L.-C. (2006). Human Localization via Multi-Cameras and Floor Sensors in Smart Home. 2006 IEEE Conference on Systems, Man, and Cybernetics (pp. 3822-3827). Taipei, Taiwan: IEEE.

Zeifman, M., \& Roth, K. (2011, February). Nonintrusive Appliance Load Monitoring: Review and Outlook. IEEE Transactions on Consumer Electronics, 57(1), 76-84.

Zukerman, I., \& Albrecht, D. W. (2001). Predictive Statistical Models for User Modeling. User Modeling and User-Adapted Interaction 11: 5-18, 2001. (pp. 5-18). Netherlands: Kluwer Academic Publishers. 


\section{Appendix A}

Appliance Load Shapes in a 24-Hour Period Generated Using Appliance Models Contained in GridLAB-D Simulation Software 



\section{Appendix A}

\section{Appliance Load Shapes in a 24-Hour Period Generated Using Appliance Models Contained in GridLAB-D Simulation Software}

This appendix contains the appliance load shape graphs generated by simulating multi-state appliance models in GridLAB-D. GridLAB-D is an open-source, state-of-the-art software designed at PNNL for the Department of Energy's Office of Electricity Delivery and Energy Reliability (DOE-OE) to simulate the complexities of the smart grid from the substation down to the end-use load. The load shapes from the ELCAP $^{1}$ load study are used to estimate the usage pattern of the appliances at different times, during the course of an average day.

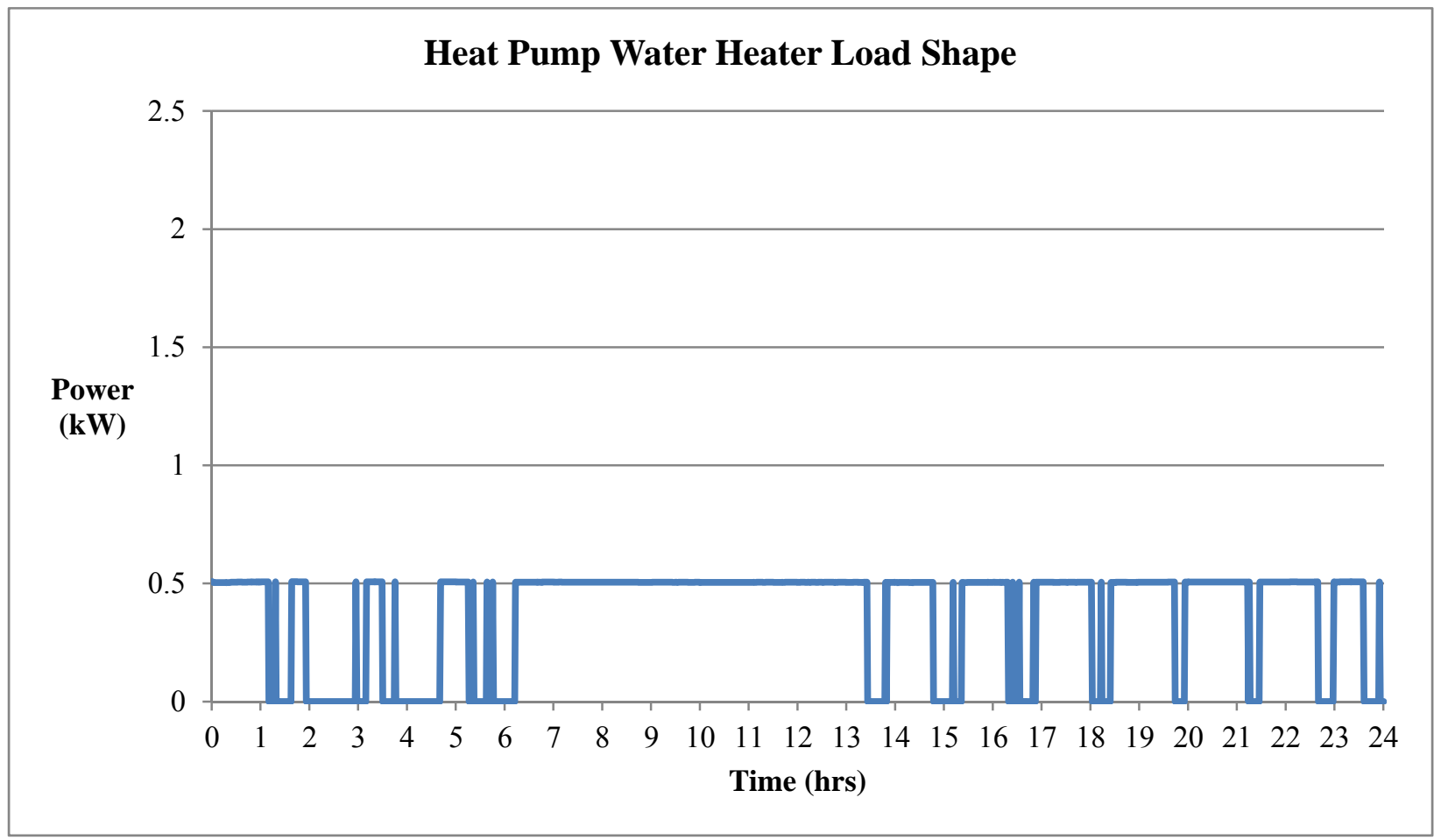

Figure A.1. Heat pump water heater load shape for a 24 hour period with high usage

\footnotetext{
${ }^{1}$ R. G. Pratt, C. C. Conner, E. E. Richman, K. G. Ritland, W. F. Sandusky, and M. E. Taylor, "Description of Electric Energy Use in Single-family Residences in the Pacific Northwest," DOE/BP 13795 21, Bonneville Power Administration, Portland, OR, 1989.
} 


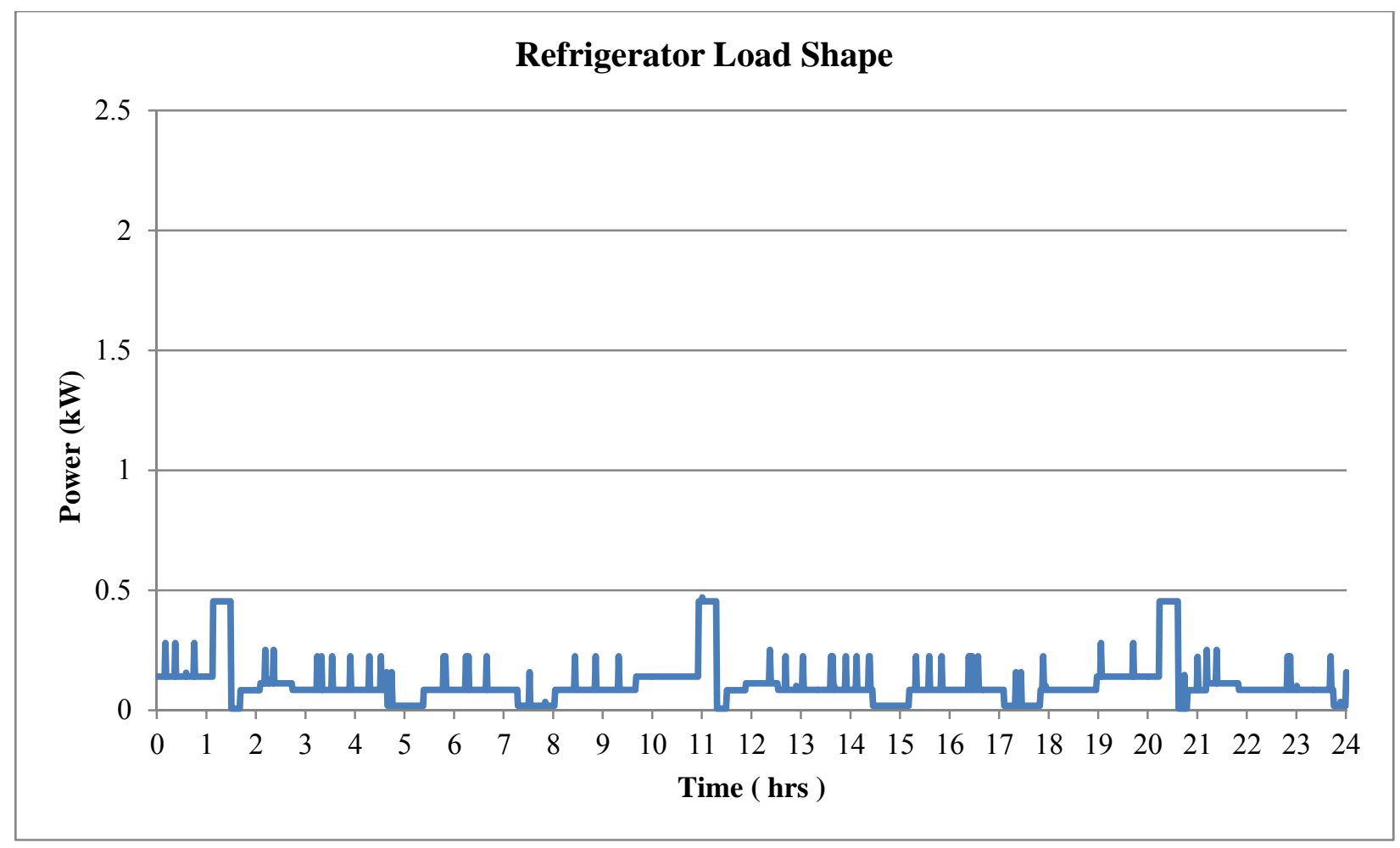

Figure A.2. Refrigerator load shape for a 24 hour period 

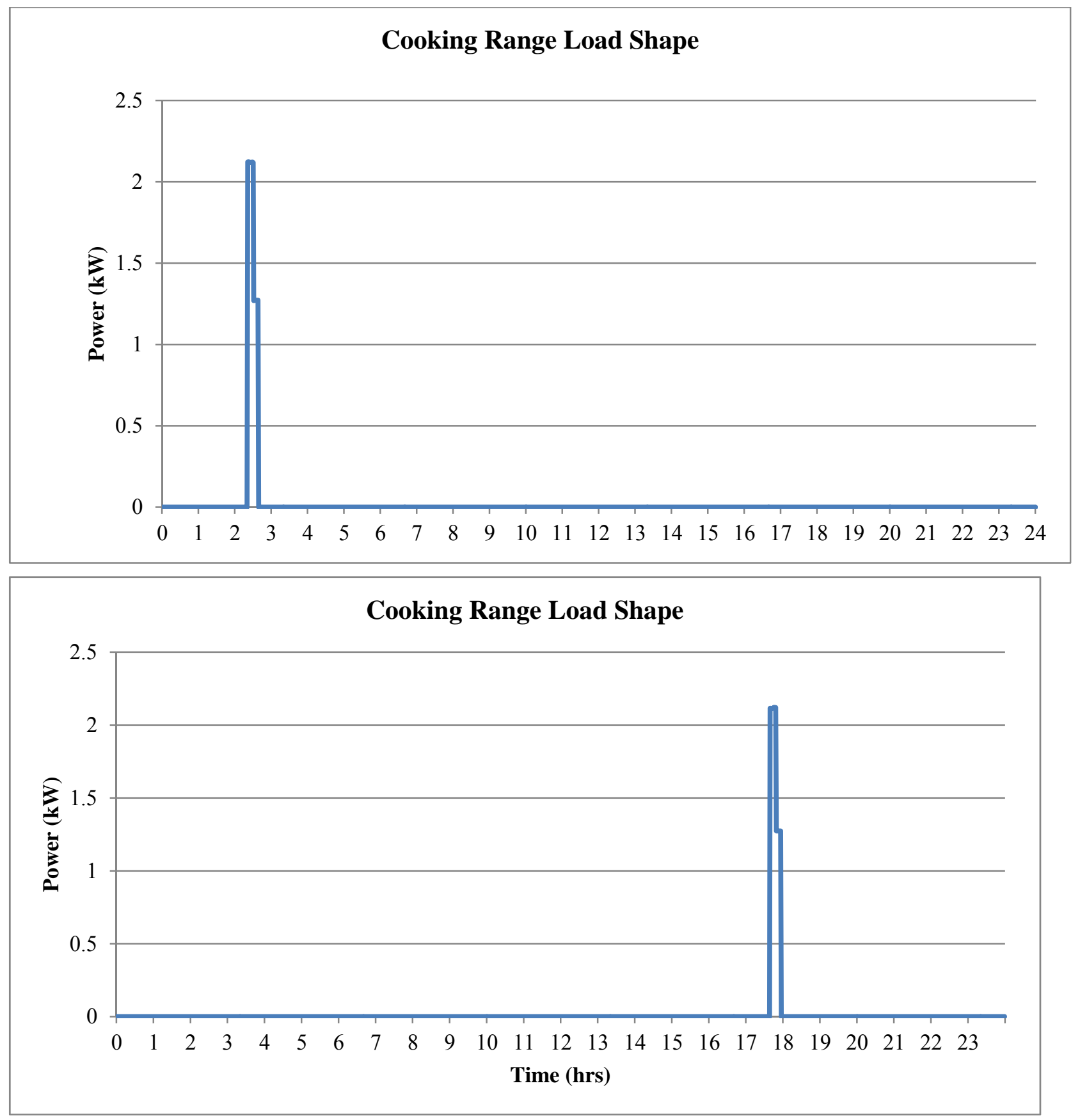

Figure A.3. Cooking range load shape for one cycle over a 24 hour period 


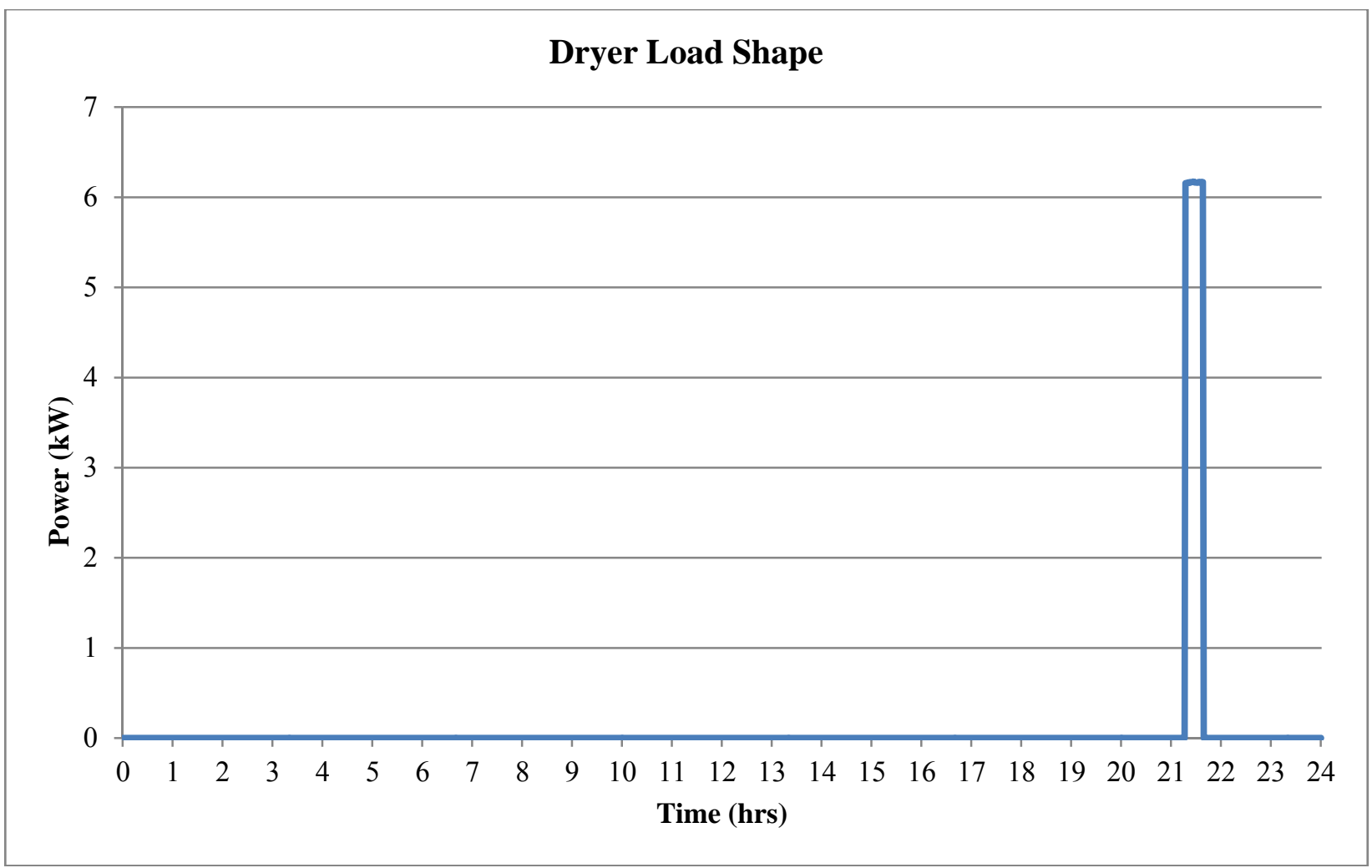

Figure A.4. Clothes dryer load shape for one cycle over a 24 hour period

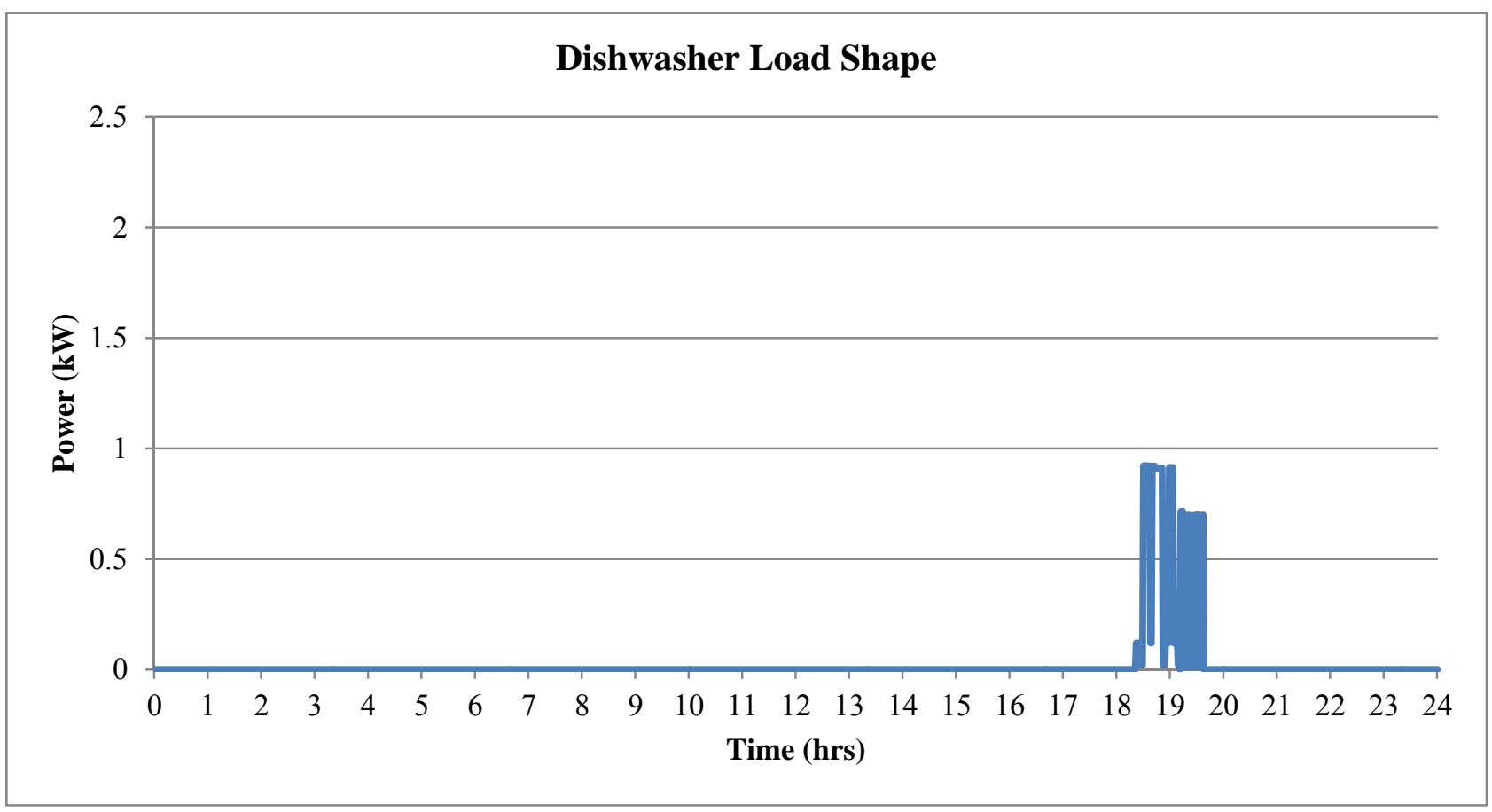

Figure A.5. Dishwasher load shape for one cycle over a 24 hour period 


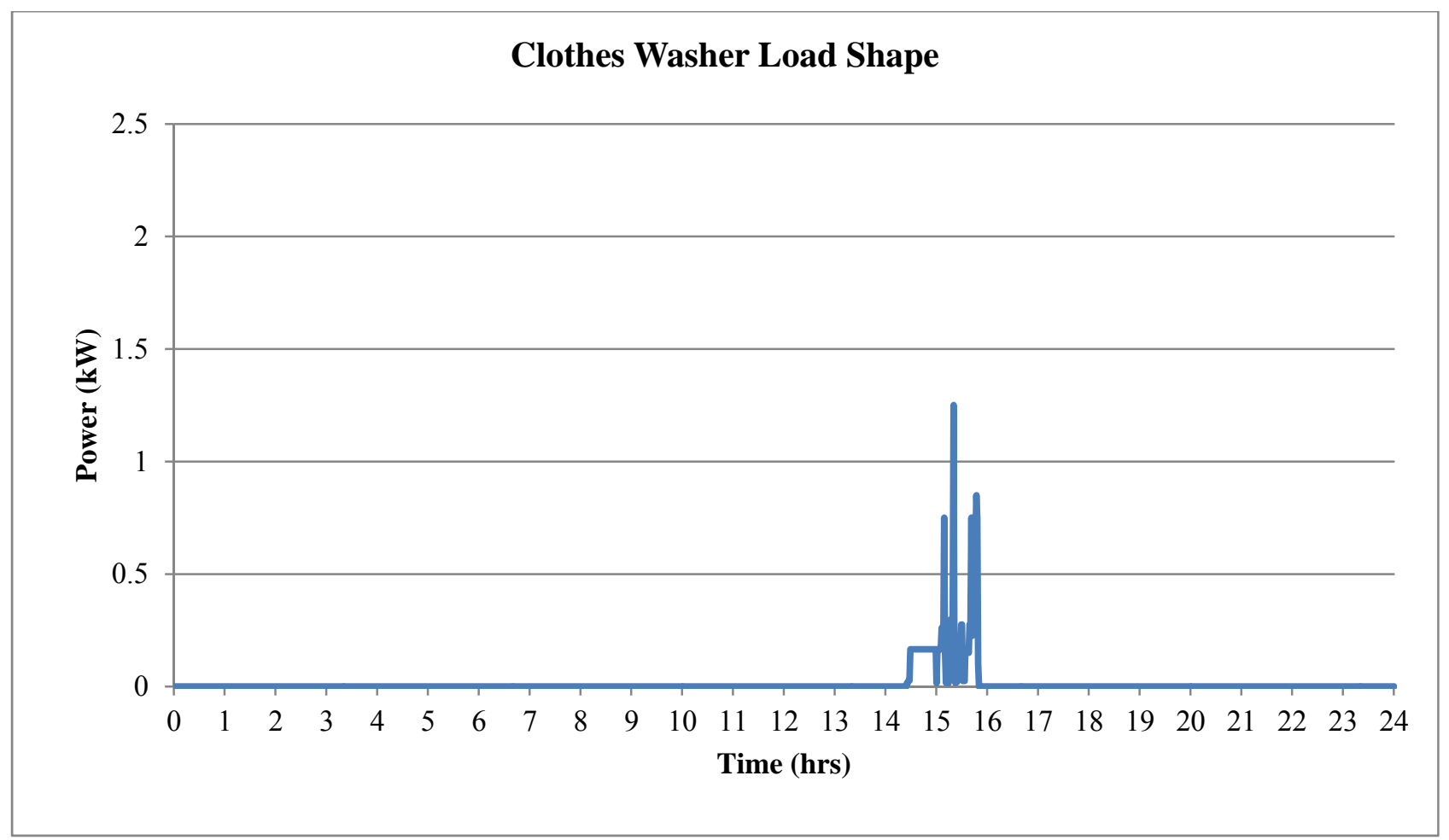

Figure A.6. Clothes washer load shape for one cycle over a 24 hour period 



\section{Appendix B}

Market Size Estimation for Replacement Appliances Based on Age 



\section{Appendix B}

\section{Market Size Estimation for Replacement Appliances Based on Age}

This appendix summarizes 2009 Residential Energy Consumption Survey (RECS) data based on year of construction of homes and age of appliances. This data has been used to estimate number of appliances that reach the end of their life expectancy in near future. We assume these appliances have potential to be replaced with smart appliances if their first cost is justifiable.

Figure B.1 - Figure B.5 show number of appliances based on their age for different construction vintages. This data can also be used to determine smart appliances target market. For example, most refrigerators reaching their maximum life expectancy may be found in homes constructed between 1980 and 1989 (Figure B.1). In addition, RECS (2009) also classifies data by type of housing unit, number of household members, household income, census region and climate region. Depending on factors that play major role in determining target market for smart appliances, it is possible to analyze data accordingly. It is therefore possible to conclude that refrigerators reaching their maximum life are located in census region South, climate region very cold/cold, and in houses owned by those whose income is less than $\$ 40 \mathrm{~K}$ but are above poverty line.

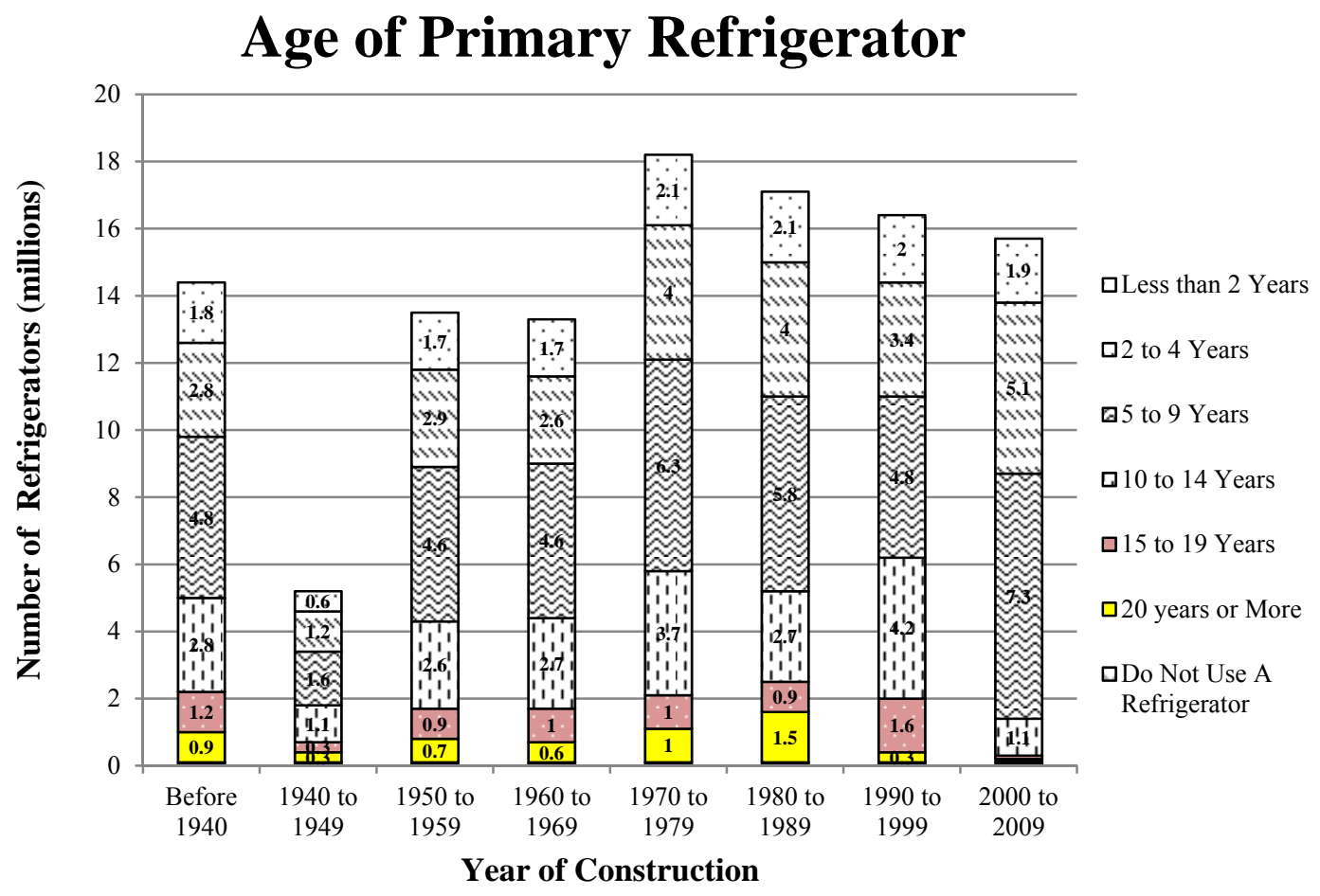

Figure B.1. Number of refrigerators classified by their age and year of construction of homes. Refrigerators older than 15 years have replacement potential (data highlighted in pink and yellow). 


\section{Age of Clothes Washer}

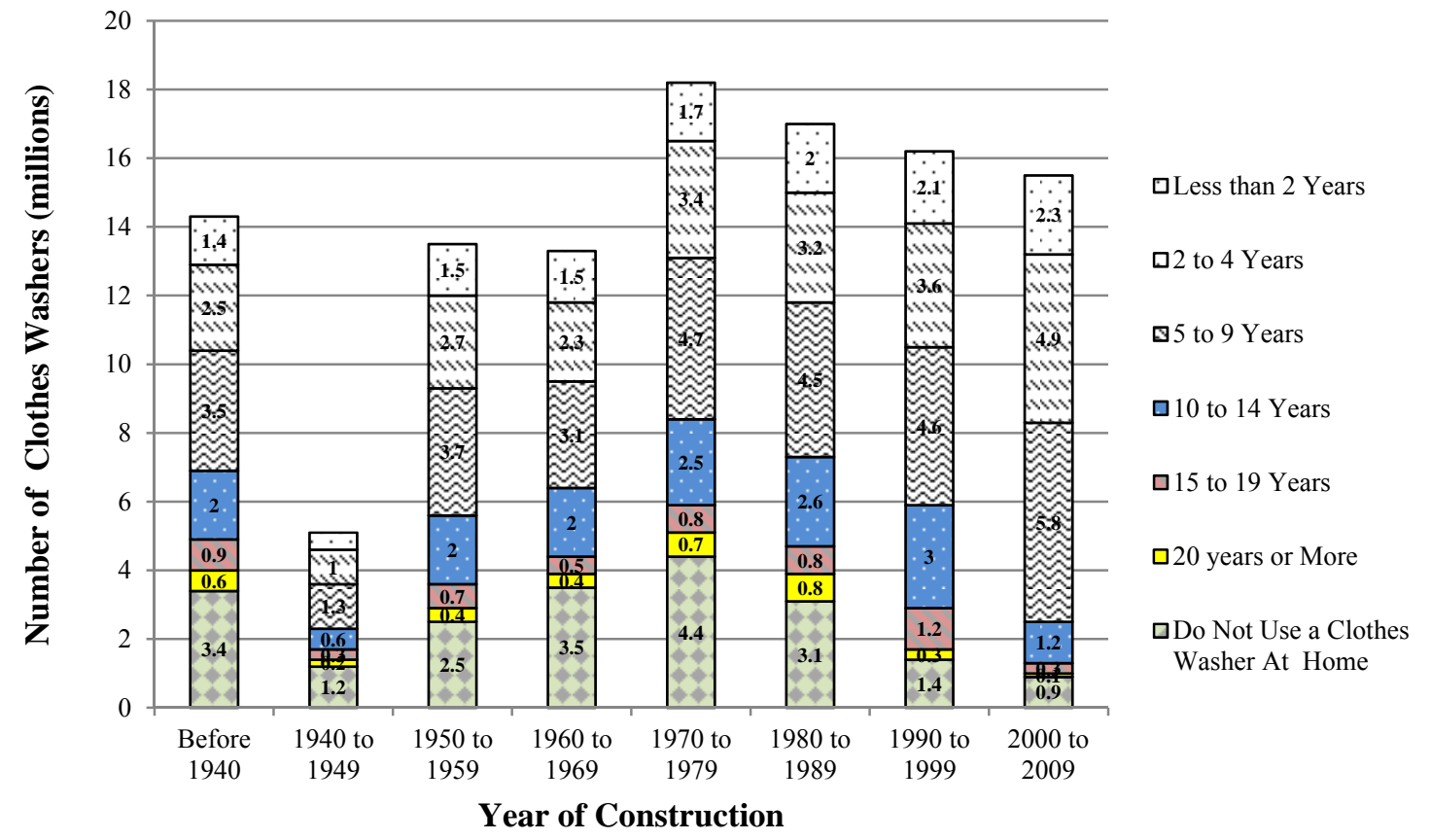

Figure B.2. Number of clothes washers classified by their age and year of construction of homes.

Clothes washers older than 10 years have replacement potential (data highlighted in blue, pink, and yellow).

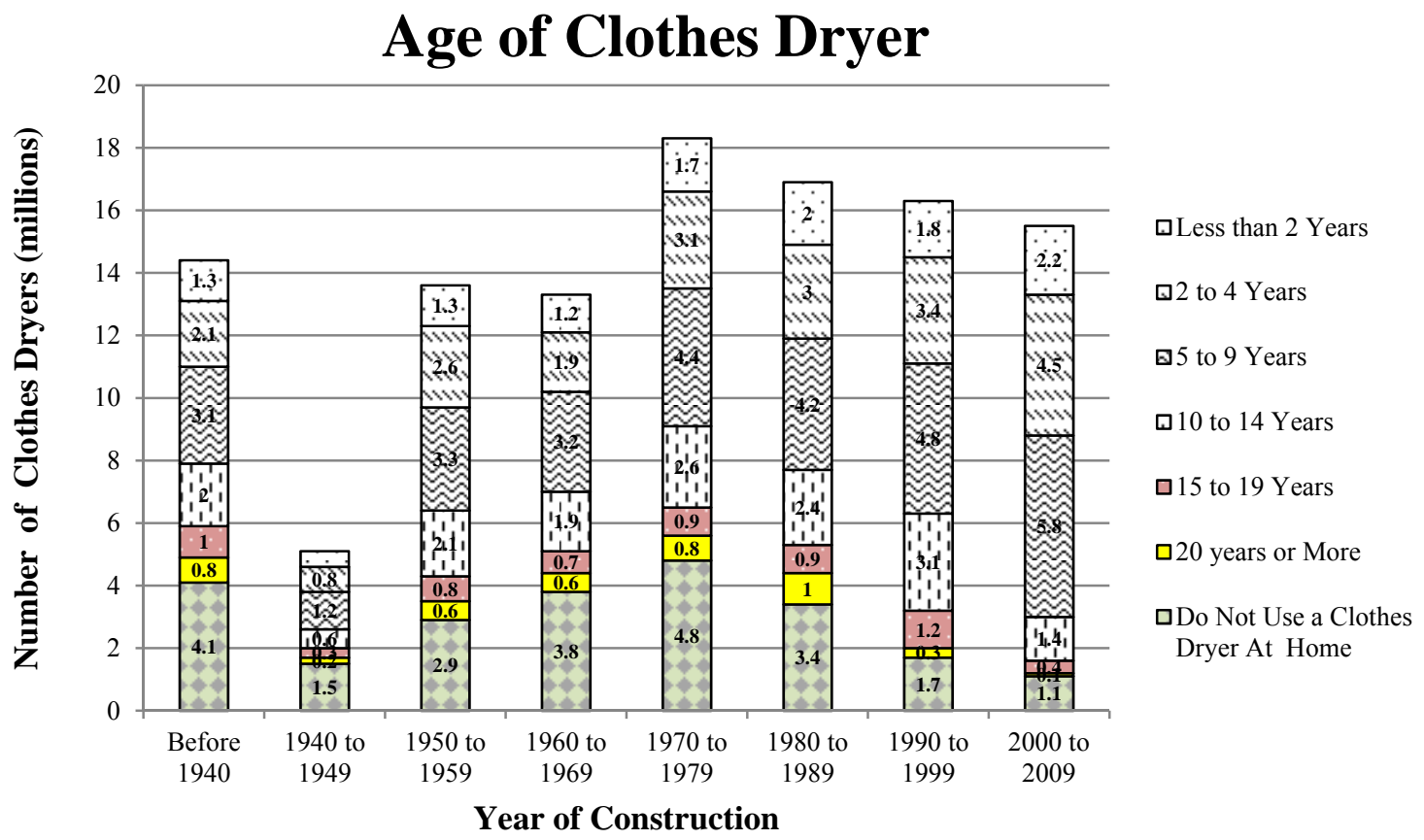

Figure B.3. Number of clothes dryers classified by their age and year of construction of homes. Clothes dryers older than 15 years have replacement potential (data highlighted in pink and yellow). 


\section{Age of Dishwasher}

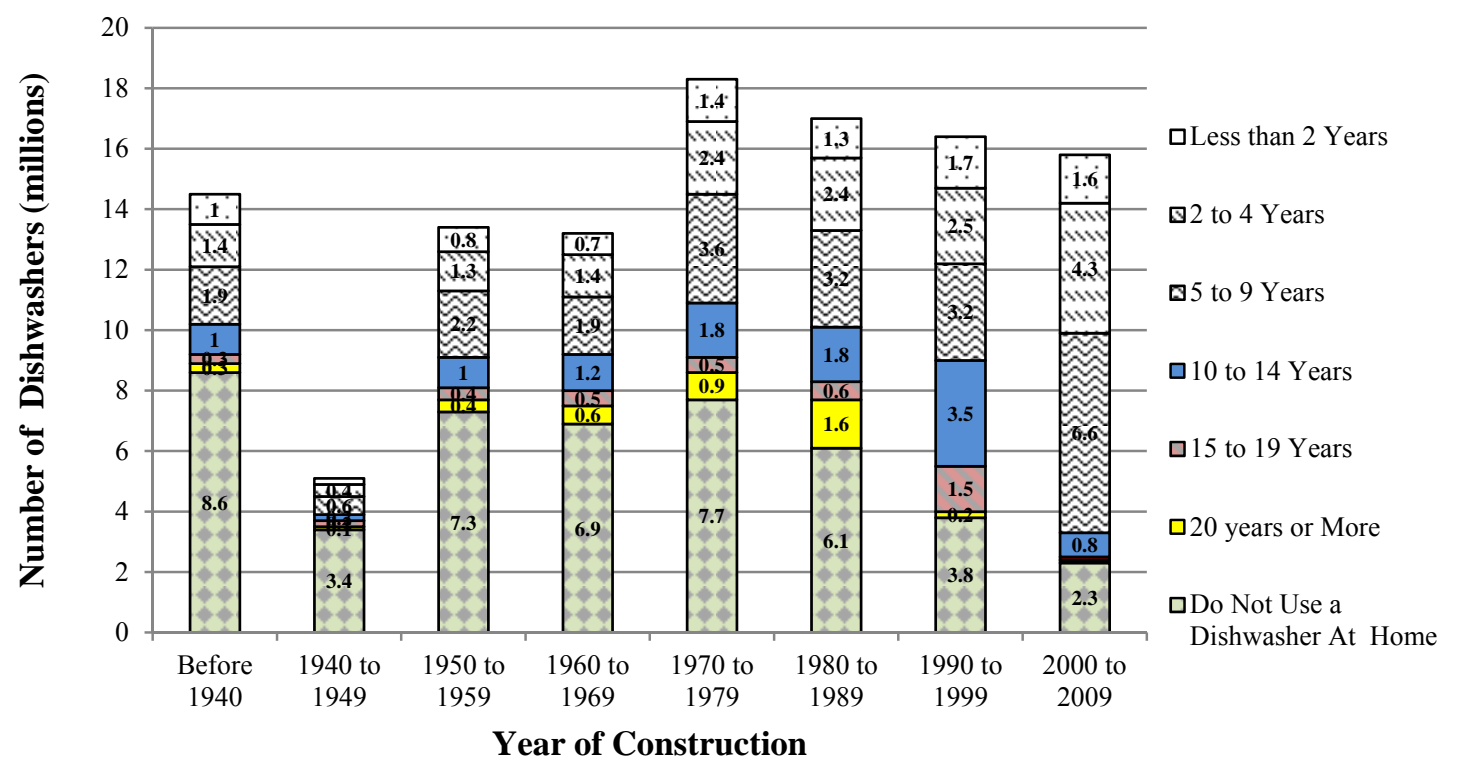

Figure B.4. Number of dishwashers classified by their age and year of construction of homes.

Dishwashers older than 10 years have replacement potential (data highlighted in blue, pink and yellow).

\section{Age of Main Water Heater}

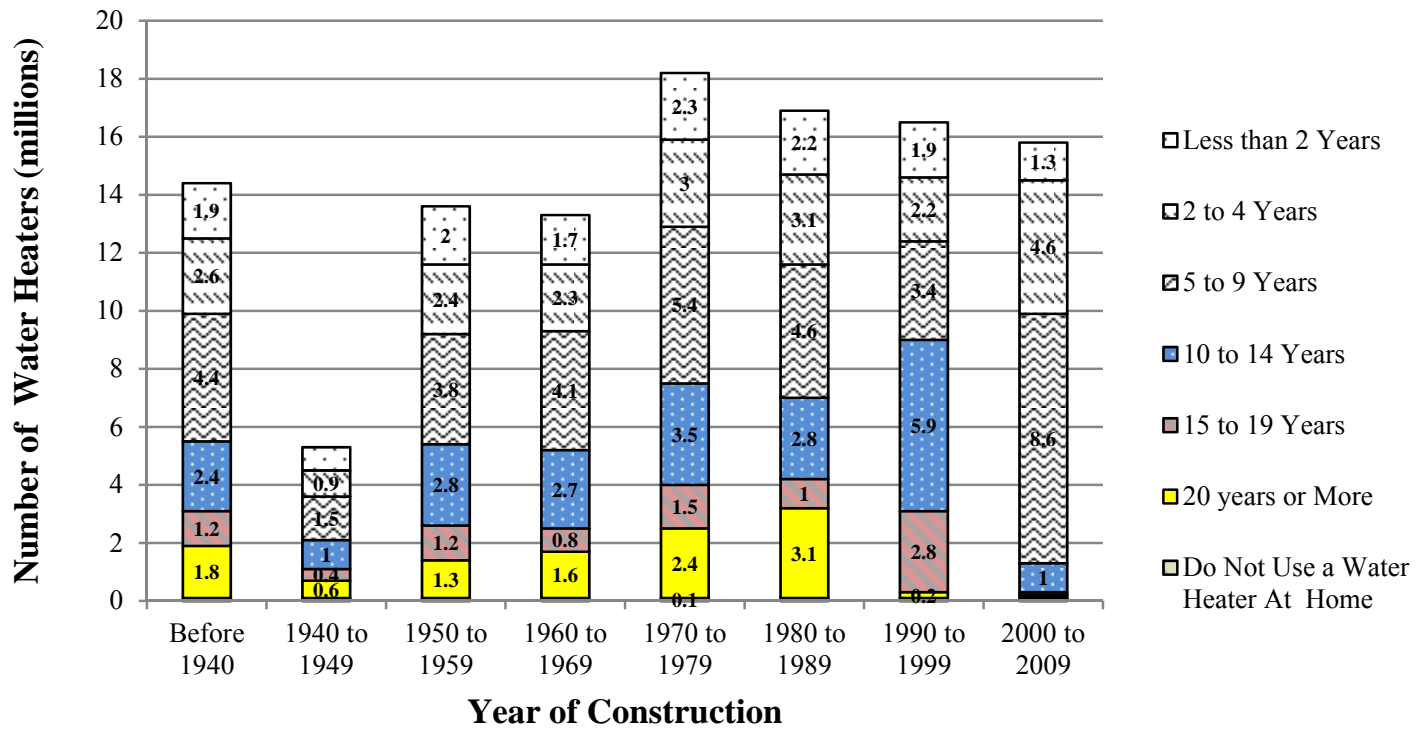

Figure B.5. Number of water heaters classified by their age and year of construction of homes. Water heaters older than 10 years have replacement potential (data highlighted in blue, pink and yellow). 



ENERGY

Emerging Technologies Program

http://www1.eere.energy.gov

PNNL-22516 • April 2013 